MILENE SCHMIDT DO AMARAL E LUNA

ANÁLISE PROTEÔMICA COMPARATIVA DA EXPRESSÃO DIFERENCIAL DE PROTEÍNAS INDUZIDA PELA ATIVAÇÃO DA INERVAÇÃO NORADRENÉRGICA EM GLÂNDULAS DE VENENO E ACESSÓRIA DA SERPENTE BOTHROPS JARARACA

Tese apresentada ao Programa de Pós-Graduação em Biologia Celular e Tecidual do Instituto de Ciências Biomédicas da Universidade de São Paulo, para obtenção de Título de Doutor em Ciências. 
MILENE SCHMIDT DO AMARAL E LUNA

\section{ANÁLISE PROTEÔMICA COMPARATIVA DA EXPRESSÃO DIFERENCIAL DE PROTEÍNAS INDUZIDA PELA ATIVAÇÃO DA INERVAÇÃO NORADRENÉRGICA EM GLÂNDULAS DE VENENO E ACESSÓRIA DA SERPENTE BOTHROPS JARARACA}

Tese apresentada ao Programa de Pós-graduação em Biologia Celular e do Desenvolvimento do Instituto de Ciências Biomédicas da Universidade de São Paulo, para obtenção de Título de Doutor em Ciências.

Área de concentração: Biologia Celular e Tecidual

Orientadora: Dra. Norma Yamanouye

Versão original 
DADOS DE CATALOGAÇÃO NA PUBLICAÇÅO (CIP)

Serviço de Biblioteca e Informação Biomédica do

Instituto de Cièncias Biomédicas da Universidade de Săo Paulo

reproduçăo năo autortzada pelo autor

Luna, Milene Schmidt do Amaral e.

Análise proteómica comparativa da expressão diferencial de proteínas induzida pela ativação da inervaçäo noradrenérgica em glândulas de veneno e acessória da serpente Bothrops jararaca I Milene Schmidt do Amaral e Luna. - São Paulo, 2013.

Orientador: Profa. Dra. Norma Yamanouye.

Tese (Doutorado) - Universidade de São Paulo. Instituto de Ciências Biomédicas. Departamento de Biologia Celular e do Desenvolvimento. Área de concentraçäo: Biologia Celular e Tecidual. Linha de pesquisa: Mecanismos envolvidos na produçäo e secreção de veneno pelo aparelho glandular de veneno de serpentes viperidae.

Versão do título para o inglês: Comparative proteomic analysis of differential expression induced by noradrenergic innervation in venom gland and acessory gland of Bothrops jararaca snake.

1. Bothrops jararaca 2 . Glândula de veneno 3 . Glândula acessória 4. Proteínas 5. Ciclo de produção de veneno 6 . Inervação noradrenérgica I. Yamanouye. Profa. Dra. Norma II. Universidade de Säo Paulo. Instituto de Cièncias Biomédicas. Programa de PósGraduação em Biologia Celular e Tecidual III. Título. 
UNIVERSIDADE DE SÃO PAULO

INSTITUTO DE CIÉNCIAS BIOMÉDICAS

\begin{abstract}
Candidato(a):
Milene Schmidt do Amaral e Luna.

Título da Tese:

Análise proteômica comparativa da expressão diferencial de proteínas induzida pela ativação da inervação noradrenérgica em glândulas de veneno e acessória da serpente Bothrops jararaca.
\end{abstract}

Orientador(a):

Profa. Dra. Norma Yamanouye.

A Comissão Julgadora dos trabalhos de Defesa da Tese de Doutorado, em sessão pública realizada a .J. considerou
( ) Aprovado(a)
( ) Reprovado(a)

$\begin{array}{ll}\text { Examinador(a): } & \begin{array}{l}\text { Assinatura: } \\ \text { Nome: } \\ \text { Instituição: }\end{array} \\ \text { Examinador(a): } & \begin{array}{l}\text { Assinatura: } \\ \text { Nome: } \\ \text { Instituição: }\end{array} \\ \text { Examinador(a): } & \begin{array}{l}\text { Assinatura: } \\ \text { Nome: } \\ \text { Instituição: }\end{array} \\ \text { Examinador(a): } & \begin{array}{l}\text { Nssinatura: } \\ \text { Instituição: }\end{array} \\ \text { Pssinatura: } & \begin{array}{l}\text { Nome: } \\ \text { Instituição: }\end{array}\end{array}$




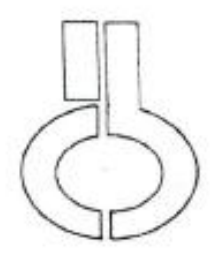

UNIVERSIDADE DE SÃO PAULO INSTITUTO DE CIÊNCIAS BIOMÉDICAS

Cidade Universitária "Armando de Salles Oliveira"

Av. Prof. Lineu Prestes, 2415 - CEP. 05508-000 São Paulo, SP - Brasil

Telefone :(55) (011) 3091.7733 - telefax : (55) (011) 3091.7438

e-mail: cepaicb.usp.br

\section{Certificado}

Certificamos que o protocolo registrado sob $\mathrm{n}^{\circ} \mathbf{1 3 8}$ nas fls. $\mathbf{7 4}$ do livro 02 para uso de animais em experimentação, sob a responsabilidade do $\operatorname{Prof}(a) \operatorname{Dr}(a)$ Norma Yamanouye, Coordenador(a) da Linha de pesquisa Mecanismos envolvidos no controle da produção e secreção de veneno pelo aparelho glandular de veneno de serpente Viperidae do qual participou(aram) o(s) alunos Milene Schmidt do Amaral e Luna, Fernanda Sakai, está de acordo com os Principios Éticos de Experimentação Animal adotado pela Sociedade Brasileira de Ciência de Animais de Laboratório (SBCAL) e foi aprovado pela COMISSÃO DE ÉTICA EM EXPERIMENTAÇÃO ANIMAL (CEEA) em 05.11.09, com validade de 3 anos.

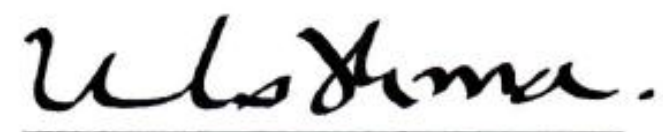

Prof.Dr.WOTHAN TAVARES DE LIMA

Coordenador CEEA - ICB/USP
São Paulo, 09 de novembro de 2009.

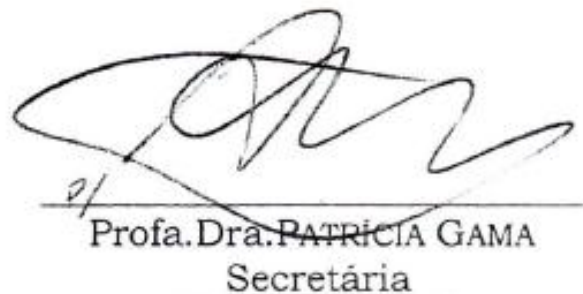

CEEA - ICB / USP

Prof"Dr. Ariel M. Silber

Dpto. de Parasitologia ICB - USP asilber@usp.br 


\section{COMISSÃO DE ÉTICA NO USO DE ANIMAIS \\ INSTITUTO BUTANTAN}

Av. Vital Brazil, 1500, CEP 05503-900, São Paulo, SP, Brazil

Telefone: (55) (011) 3726-7222 ramal 2106 - Fax: (55) (011) 3726-1505

\section{CERTIFICADO}

Certificamos que o Projeto intitulado "Análise proteômica comparativa da expressão diferencial de proteínas induzida pela ativação da inervação noradrenérgica em glândulas de veneno da serpente Bothrops jararaca", protocolo $\mathrm{n}^{\circ} \mathbf{5} \mathbf{5} 5 / \mathbf{0 8}$, sob a responsabilidade de Norma Yamanouye e Milene Schmidt do Amaral e Luna, está de acordo com os Princípios Éticos na Experimentaçăo Animal adotado pelo Colégio Brasileiro de Experimentação Animal (COBEA), e foi aprovado pela COMISSÃO DE ÉTICA NO USO DE ANIMAIS DO INSTITUTO BUTANTAN (CEUAIB) em reunião de 12/11/2008.

We certify that the research entitled "Comparative proteomic analysis of the differential expression of proteins induced by noradrenergic inervation in venom gland of snake Bothrops jararaca", protocol $n^{\circ} 555 / 08$, under the responsibility of Norma Yamanouye and Milene Schmidt do Amaral e Luna, is in agreement with the Ethical Principles in Animal Research, adopted by the Brazilian College of Animal Experimentation, and was approved by the ETHICAL COMMITTEE FOR ANIMAL RESEARCH of BUTANTAN INSTITUTE in the meeting of $\underline{11 / 12 / 2008}$.

\begin{tabular}{l|c|}
\hline $\begin{array}{l}\text { Vigência do Projeto: } \\
01 / 12 / 2008-04 / 06 / 2013\end{array}$ & $\mathrm{~N}^{\prime \prime}$ de animais/espécie \\
\hline \multirow{2}{*}{} & 35 serpentes Bothrops jararaca fẻmeas \\
& 35 serpentes Bothrops jararaca machos \\
\cline { 2 - 2 }
\end{tabular}

De acordo:

São Paulo, 13, de Novembro de 2008.

Dr. Otávî́ Azevedòlercadante

Diretor do Instituto Butantan 


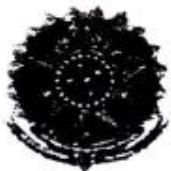 \\ SERVICO PÚBLICO FEDERAL \\ MINISTÉRIO DO MEIO AMBIENTE \\ INSTITUTO BRASILEIRO DO MEIO AMBIENTE E DOS RECURSOS NATURAIS RENOVÄVEIS \\ AUTORIZAÇÃO ESPECIAL DE ACESSO E DE REMESSA DE AMOSTRA DE COMPONENTE DO PATRIMÔNIO GENÉTICO No 01/2009
}

\begin{abstract}
O INSTITUTO BRASILEIRO DO MEIO AMBIENTE E DOS RECURSOS NATURAIS RENOVÁVEIS, IBAMA no uso das competências que lhe foram conferidas pela $n^{\circ}$ 040/CGEN, de 24 de setembro de 2003, resolve:

Autorizar o Instituto Butantan, constituído sob o CNPJ $n^{\circ}$ 61.821.344/0001-56, representado legaimente pelo Diretor Otávio de Azevedo Mercadante, inscrito sob o CPF $n^{\circ} 041.394 .618-53$, a acessar e remeter amostras de componente do patrimônio genético no âmbito dos projetos de pesquisa que compõem o portfólio de projetos do Instituto Butantan para o desenvolvimento de pesquisas cientificas sem perspectiva de uso comercial, aplicação industrial ou bioprospecção.
\end{abstract}

Local de depósito de subamostra: Museu de Zoologia da Universidade de São Paulo e o Instituto Butantan (Deliberações do Conselho de Gestão do Patrimônio Genético n 2, de 8 de julho de 2002 e n 147 , de 29 de Junho de 2006, respectivamente).

Localização da Instituição detentora desta autorização: Av. Vital Brazil, 1500, São Paulo, SP, 05503-900.

Validade da Autorização: 23 de janeiro de 2009 a 23 de janeiro de 2011, prorrogável por mais dois anos. $O$ Instituto Butantan deverá enviar ao Ibama relatório anual das atividades desenvolvidas no âmbito dos projetos de pesquisa autorizados, nos termos do Decreto $n^{\circ} 4.946 / 2003$.

Esta autorização vincula-se às informações fornecidas e termos de compromissos assinados pelo iequerente constantes no processo $n^{\circ} 02001.005106 / 2008$ e demais processos pertinentes. Não estão autorizadas atividades de acesso e de remessa de componente do patrimônio genético com finalidade de bioprospecção, desenvolvimento técnológico ou uso comercial e/ou industrial.

Caso seja identificado uso econômico de produto ou processo, passível ou não de proteção intelectual, originado das referidas amostras, obriga-se a instituição solicitante a adotar as providências cabiveis junto ao Conselho de Gestão de Patrimônio Genético, com vistas à formalização de Contrato de Utilização do Patrimônio Genético e de Repartição de Beneficios, conforme Medida Provisória n 2.186/16, de 2001, Decretos $n^{\circ} 3.945 / 2001$ e n ${ }^{\circ} 4.946 / 2003$.

Durante a vigência desta autorização, o Instituto Butantan poderá inserir novas atividades ou projetos no portfólio, desde que observe as condições estabelecidas na legislação pertinente e, no prazo de sessenta dias a partir do início da nova atividade ou projeto, comunique ao IBAMA qualquer alteração ou inserção de novas atividades ou projetos no portfólio do Instituto Butantan, conforme disposto no $\S 4^{\circ}$, art. $9^{\circ}$, do Decreto $n^{\circ}$ 4.946/2003.

As remessas de componentes do patrimônio genético deverão ser precedidas de assinatura dos Termos de Transferência de Material, conforme dispõe o Art. 19, inciso IV, da Medida Provisória $n^{\circ}$ 2.186-16/2001. Para a remessa ou transporte de componente do patrimônio genético para instituição sediada no exterior, o Instituto Butantan, deverá solicitar ao IBAMA licença de exportação complementar a esta Autorização Especial.

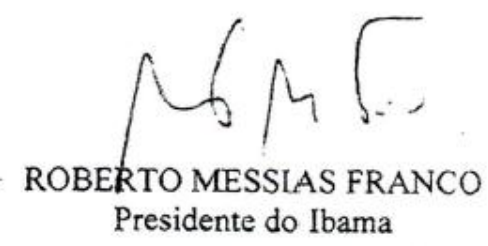

Brasilia, 23 de janeiro de 2009. 


\section{(1) \\ SERVIÇO PÚBLICO FEDERAL \\ MINISTÉRIO DO MEIO AMBIENTE}

INSTITUTO BRASILEIRO DO MEIO AMBIENTE E DOS RECURSOS NATURAIS RENOVȦVEIS

DIRETORIA DE USO SUSTENTÁVEL DA BIODIVERSIDADE E FLORESTAS

SCEN - Ed. Sede do Ibama - Bloco B - 70.818-900 - Brasilia - DF

Cx. Postal: 09.870 - Telefone: (61) 3316.1650 - Fax: (61) 3316.1200

Ofício $n^{\circ} \cdot / 3 / 2008 / \mathrm{DBFLO}$

A Sua Senhoria o Diretor Otávio de Azevedo Mercadante Instituto Butantan

Av. Vital Brazil, 1500, São Paulo, SP

05503-900

Assunto: Autorização especial de acesso e remessa de patrimônio genético do Instituto Butantan.

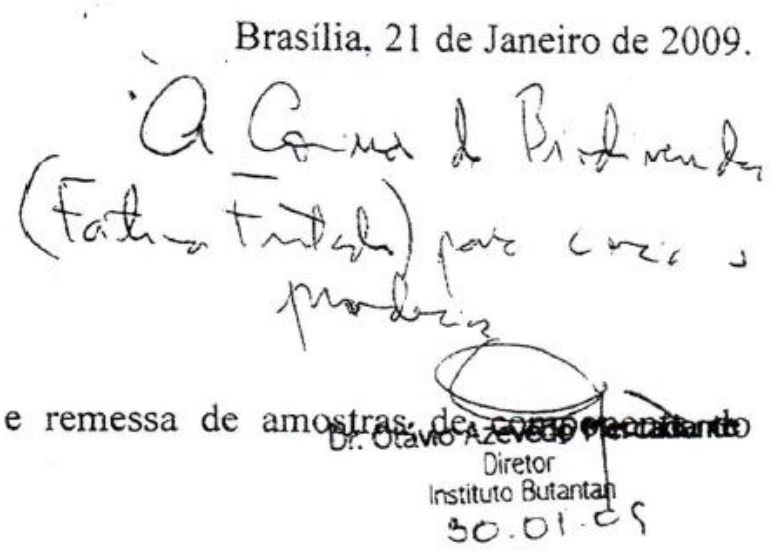

Senhor Diretor,

1. Cumprimentando-o, e reportando-me a solicitação de V. Sa. referente ao acesso e remessa de patrimônio genético, dirijo-me com o objetivo de encaminhar autorização especial de acesso e remessa de amostras de componente do patrimônio genético $\mathrm{n}^{\circ}$ 01/2009/1BAMA, referente ao processo $n^{\circ}$ 02001.005106/2008 e demais processos listados em anexo.

2. O aludido documento permite o acesso e a remessa de amostras de componente do patrimônio genético no âmbito dos projetos de pesquisa que compõem o portifólio de projetos do Instituto Butantan. Em apenso consta relação dos projetos de pesquisa contemplados pela autorização especial de acesso e remessa n 01/2009.

3. A Autorização Especial n 01/2009 tem validade de 02 (dois) anos, renovável por igual periodo. O Instituto Butantan deverá enviar ao Ibama relatório anual das atividades desenvolvidas no âmbito dos projetos de pesquisa autorizados. 
Aos meus pais, Creusa e Josué que nunca mediram esforços para eu continuar os meus estudos e sempre me impulsionaram a seguir os meus caminhos. Obrigada!

A minha querida irmã Nelise por ser você mesma, pela sua amizade, carinho e apoio sempre. 
Ao meu querido marido, dedico a você Marcio este trabalho pelo seu amor e respeito por minhas escolhas. Por estar ao meu lado em todos os momentos. Por conhecer todos os meus defeitos e mesmo assim me amar!!!

Marcela a continuação e o sentido da vida!

A forma mais pura do amor, a estrela que brilha em minha vida.

Por você tudo vale a pena! 


\section{AGRADECIMENTOS}

Este trabalho é fruto de muita dedicação, trabalho e persistência. Contei com o apoio e a colaboração de muitas pessoas, as quais eu dedico meus agradecimentos especiais:

À Dra. Norma Yamanouye, minha orientadora, que me transmitiu conhecimentos valiosos, sempre me motivou e acima de tudo me ensinou a caminhar com minhas próprias pernas. Expresso minha profunda gratidão pela perfeita combinação de orientação e amizade.

Ao Laboratório de Farmacologia do Instituto Butantan pela oportunidade de trabalhar ao lado de pessoas agradáveis e pela convivência durante todos os anos.

Aos pesquisadores do Laboratório de Farmacologia do Instituto Butantan que direta ou indiretamente, contribuíram para realização deste trabalho.

Ao Laboratório de Herpetologia do Instituto Butantan pelo fornecimento e classificação das serpentes Bothrops jararaca.

A Celiana, secretária do Programa de pós-graduação do Departamento de Biologia Celular e do Desenvolvimento do Instituto de Ciências Biomédicas da USP que sempre esclareceu minhas duvidas.

Ao Dr. Richard Hemmi Valente, Laboratório de Toxinologia do Instituto Oswaldo Cruz, que gentilmente me recebeu em seu laboratório e me ensinou um pouco sobre o Universo do Proteoma. Pela Paciência, dedicação e horas de Skype dispensadas para sanar minhas duvidas. Principalmente pela identificação das proteínas por Espectrometria de Massas. Super Obrigada!

Ao Dr. Jonas Perales, chefe do Laboratório de Toxinologia do Instituto Oswaldo Cruz, que abriu as portas do seu laboratório e me recebeu com muito carinho juntamente com sua equipe.

A Dra. Ana Lúcia T. O. Nascimento do Laboratório de Biotecnologia Molecular do Instituto Butantan que disponibilizou os equipamentos de gel bidimensional antes de adquirirmos os nossos equipamentos.

A Ms. Mônica Larucci Vieira do Laboratório de Biotecnologia Molecular do Instituto Butantan que me ajudou muito no início deste projeto, na padronização da técnica de gel de eletroforese bidimensional.

Ao Dr. Marcelo Larami Santoro do Laboratório de Fisiopatologia do Instituto Butantan, por disponibilizar o escâner para digitalização dos géis, na etapa inicial deste projeto e ainda ceder gentilmente uma alíquota do anticorpo contra botrocetina. 
A Dra. Anita Mitico Tanaka Azevedo do Laboratório de Fisiopatologia do Instituto Butantan, por disponibilizar alguns equipamentos do sistema de gel bidimensional e ainda pelas discussões científicas.

A Dra. Ana Maria Moura da Silva do Laboratório de Imunopatologia do Instituto Butantan pelas sugestões e por ceder gentilmente uma alíquota dos anticorpos contra metaloproteinase $\mathrm{BnP1}$ e jararagina.

Ao Dr. Inácio Junqueira de Azevedo e a Dra. Solange Serrano do Laboratório Especial de Toxinologia aplicada ambos por me conceder uma alíquota dos anticorpos contra PDI e serinoproteinase, respectivamente.

Agradecimento às amigas, Andréia, Luciana, Adriana "Dri Morena", do laboratório de Farmacologia pela agradável convivência, pelas discussões científicas e aos Happy hours.

Agradecimento especial aos amigos Cintia e Thiago, pelos momentos agradáveis que passamos juntos que são inesquecíveis, pela amizade, paciência, sugestões, discussões científicas e não científicas e ótimas gargalhadas. Amo Vocês!

A minha amiga Beatriz Viana, muito obrigada pela amizade, convivência agradável e por me apresentar um pouquinho da sua terra através das guloseimas Paraenses.

A minha grande amiga Mariana Schmidt que sempre me escutou e me aconselhou nos momentos mais felizes, inclusive nos mais difíceis. Por estar sempre presente e muito bem humorada.

Aos meus queridos irmãos Gabriel e Julia simplesmente por existirem e estarem sempre presentes.

A minha mãe e minha vozinha querida Aurélia por me ajudarem muito nesta ultima etapa do Doutorado a cuidar da minha pequena.

A minha família! 
Este trabalho foi realizado com o auxílio financeiro do Conselho Nacional de Pesquisa (CNPq), através da concessão da Bolsa de Doutorado (142525/2008-1) e com o auxílio à pesquisa da Fundação de Amparo a Pesquisa do Estado de São Paulo (FAPESP - 07-50083-9). 


\section{RESUMO}

LUNA, M. S. A. Análise proteômica comparativa da expressão diferencial de proteínas induzida pela ativação da inervação noradrenérgica em glândulas de veneno e acessória da serpente Bothrops jararaca. 2013. 170 f. Tese (Doutorado em Biologia Celular e Tecidual) - Instituto de Ciências Biomédicas, Universidade de São Paulo, São Paulo, 2013.

As glândulas de veneno de serpentes Viperidae possuem um lumen onde todo veneno produzido pelas células secretoras é estocado. Quando o veneno é liberado do lumen, as células secretoras são ativadas e mais veneno é produzido. Mostramos anteriormente que a extração de veneno promove modificações na síntese de proteínas da glândula de veneno. Nesta tese, realizamos um estudo proteômico das glândulas de veneno e acessória durante o ciclo de produção de veneno e verificamos a influência da inervação noradrenérgica na regulação da síntese de proteínas da glândula de veneno. Foram identificadas espécies de proteínas exclusivas em cada estágio. Dentre as proteínas do citoplasma, verificamos que o número de espécies de proteínas exclusivas identificadas como actina, vimentina, tropomiosina, da subunidade alfa do proteassomo, tioredoxina e da proteína 40S ribossomal aumentou após a extração de veneno. Quanto às proteínas do retículo endoplasmático, verificamos um aumento no número de proteínas exclusivas identificadas como proteína PDI e GRP78 após a extração de veneno. Em relação às proteínas secretadas, identificadas como toxinas do veneno, mostramos pela primeira vez que a maioria das toxinas do veneno já está presente no estágio quiescente da glândula. As SVSP são mais abundantes no estágio quiescente e as CTL-símile como as GPIb-BP e fator de coagulação IX/X estão presentes somente no estágio quiescente. Outras toxinas como SVMP, LAAO, PLA 2 , PLI, Bj46a e disintegrina são mais abundantes nos estágios ativados da glândula, demonstrando que a produção e secreção de toxinas ocorrem de maneira não sincronizada. A inervação noradrenérgica regulou positivamente a síntese de vimentina e subunidade alfa do proteassomo e negativamente a síntese da cadeia leve da miosina, anexina A5 e ATP-sintase mitocondrial-símile. Em relação às toxinas, a inervação noradrenérgica regulou negativamente a síntese das CTL-símile como as GPIb-BP e o fator de coagulação IX/X, além das PLA $_{2}$ e da SVMP-PII e positivamente a síntese de Bj46a e da SVMP-PI. Quanto à glândula acessória, a síntese da proteína nuclear histona $\mathrm{H} 2$ aumentou após a extração de veneno e a síntese das proteínas HSP90 (retículo endoplasmático) e DPPIV (membrana) reduziram após a extração de veneno. Surpreendentemente, pela primeira vez, mostramos a presença de toxinas na glândula acessória como as CTLs, SVSP, SVMP, PLA 2 , LAAO e ainda toxinas menos abundantes como disintegrina, GC, PN identificadas apenas na glândula acessória que não sofreu extração de veneno. Identificamos também a presença de inibidores de enzimas tais como PLI, Bj46a e o precursor do tripeptídeo pEKW. Interessante salientar que da classe das SVMP, apenas as SVMP-PII e SVMP-PIII foram identificadas preferencialmente 4 dias após a extração de veneno. Assim como na glândula de veneno, a produção e secreção das toxinas da glândula acessória ocorrem de maneira não sincronizada. O conhecimento da composição proteômica das glândulas do aparelho glandular de veneno de serpente nos vários estágios do ciclo de produção de veneno, bem como a participação da inervação noradrenérgica nesse processo contribuirá de forma significativa para um melhor entendimento dos mecanismos de produção e secreção de veneno, contribuindo para os estudos das toxinas e suas diversidades.

Palavras-chave: Bothrops jararaca. Glândula de veneno. Glândula acessória. Síntese de proteínas. Ciclo de produção de veneno. Inervação noradrenérgica. Serpente. Análise proteômica. 


\begin{abstract}
LUNA, M. S. A. Comparative proteomic analysis of differencitial expression induced by noradrenergic innervation in venom gland and accessory gland of Bothrops jararaca snake. 2013. 170 p. Ph. D. thesis (Cell Biology and Tissue) - Instituto de Ciências Biomédicas, Universidade de São Paulo, São Paulo, 2013.
\end{abstract}

Venom gland of viperid snakes have a basal-central lumen where the venom produced by secretory cells is stored. When the venom is depleted from the lumen, secretory cells are activated and more venom is produced. In previous studies, we have shown that venom extraction promotes changes in the protein synthesis of venom gland. In this thesis, we performed a proteomic analysis of venom gland and accessory gland during venom production cycle and verify the influence of noradrenergic innervation on protein synthesis of the venom gland. We identified exclusive proteins in each stage. Among protein species of the cytoplasm, we verify that the number of exclusive protein species identified as actin, vimentin, tropomyosin, and proteasome subunit alpha type-1, thioredoxin, and 40S ribosomal increased after venom extraction. Among protein species of the endoplasmic reticulum, we verify that the number of species of protein identified as disulfide isomerase and glucose regulated protein $78 \mathrm{kDa}$ increased after venom extraction. Regarding secreted proteins, specifically about venom toxins, we showed for the first time that many toxins are present in quiescent stage. SVSP are more abundant in quiescent stage and others toxins CTL-like such as GPIb-BP and coagulation factor IX/X were present only in this stage. Other toxins such as SVMP, LAAO, PLA 2 , PLI, Bj46a, and disintegrin are more abundant in activated stages of venom gland, indicating the production and secretion of toxins is not synchronized. Noradrenergic innervation regulates positively the synthesis of vimentin and proteasome subunit alpha and negatively the synthesis of myosin light chain and ATP-synthase mitochondrial-like. Considering toxins, noradrenergic innervation regulates negatively the synthesis of CTL-like such as GPIb-BP, coagulation factor IX/X, PLA 2 and SVMP-PII and positively the synthesis of $\mathrm{Bj} 46 \mathrm{a}$ and SVMP-PI. In the accessory gland, the synthesis of nuclear protein histone $\mathrm{H} 2$ increased after venom extraction and the synthesis of proteins HSP90 (endoplasmic reticulum) and DPPIV (membrane) decreased after venom extraction. Surprisingly, we showed for the first time the presence of toxins in accessory gland such as CTLs, SVSP, SVMP, PLA 2 , LAAO and in a less abundance, disintegrin, GC, PN identified only in accessory gland that not underwent venom extraction. We also identified the presence of enzyme inhibitors such as PLI, Bj46a and the precursor of the tripeptide pEKW. It is important to show that from SVMP class, only SVMP-PII and SVMPI-PIII were identified and mainly in accessory gland 4 days after venom extraction. Similar to venom gland, the syntheses and secretion of new toxins are asynchronized in accessory gland. The proteomic composition of gland of snake venom apparatus on different stages of venom production cycle, and the participation noradrenergic innervation in this process will contribute to better understand the mechanisms involved in venom gland activation and consequently, venom production. These data will also contribute to the studies on snake toxins and their diversities.

Keywords: Bothrops jararaca. Venom gland. Acessory gland. Protein synthesis. Venom production cycle. Noradrenergic innervation. Snake. Proteomic analysis. 


\section{LISTA DE ILUSTRAÇÕES}

Figura 1 - Serpente adulta de Bothrops jararaca em atividade sobre o solo.

Figura 2 - Crânio e mandíbula de serpente com dentição solenoglifodonte.

Figura 3 - Aparelho glandular de veneno da serpente Bothrops jararaca

Figura 4 - Representação esquemática das mudanças morfológicas das células secretoras da glândula de veneno da serpente Vipera palestinae durante o ciclo de produção de veneno.

Figura 5 - Remoção das glândulas de veneno e acessória da serpente Bothrops jararaca. 40

Figura 6 - Delineamento experimental deste projeto para identificar, na serpente Bothrops jararaca, as proteínas da glândula principal de veneno e da glândula acessória reguladas durante o ciclo de produção de veneno e ainda as proteínas da glândula principal de veneno regulada pela inervação noradrenérgica.

Figura 7 - Diagrama de Venn representando a análise comparativa dos géis 2-DE de glândulas de veneno das serpentes Bothrops jararaca fêmeas durante o ciclo de produção de veneno.. 51

Figura 8 - Gel 2-DE de SDS-poliacrilamida representativo dos diferentes spots selecionados dos extratos de glândulas de veneno das serpentes Bothrops jararaca fêmeas durante o ciclo de produção de veneno.

Figura 9 - Distribuição subcelular das proteínas identificadas em glândulas de veneno das serpentes Bothrops jararaca. 55

Figura 10 - Aumento do número de espécies de proteínas exclusivas identificadas como citoplasmáticas, do citoesqueleto, na glândula de veneno da serpente Bothrops jararaca durante o ciclo de produção de veneno.

Figura 11 - Aumento do número de espécies de proteínas exclusivas identificadas como citoplasmáticas na glândula de veneno da serpente Bothrops jararaca durante o ciclo de produção de veneno.

Figura 12 - Aumento do número de espécies de proteínas exclusivas identificadas como do retículo endoplasmático na glândula de veneno da serpente Bothrops jararaca durante o ciclo de produção de veneno.

Figura 13 - Número de espécies de toxinas identificadas como proteínas secretadas na glândula de veneno da serpente Bothrops jararaca durante o ciclo de produção de veneno. 58

Figura 14 - Número de espécies de proteínas identificadas das classes de toxinas na glândula de veneno da serpente Bothrops jararaca durante o ciclo de produção de veneno. 60

Figura 15 - Detecção de actina nos diferentes estágios do ciclo de produção de veneno. 62

Figura 16 - Detecção da SVSP (MSP1/2) nos diferentes estágios do ciclo de produção de veneno. .. 62 
Figura 17 - Diagrama de Venn representando a análise comparativa dos géis 2-DE de glândulas de veneno das serpentes Bothrops jararaca fêmeas no estágio ativado 4 dias e a influência da inervação noradrenérgica.

Figura 18 - Gel 2-DE de SDS-poliacrilamida representativo dos diferentes spots selecionados após tratamento com reserpina e agonistas de adrenoceptores alfa e beta em glândulas de veneno das serpentes Bothrops jararaca fêmeas.

Figura 19 - Distribuição subcelular das proteínas identificadas nas glândulas de veneno da serpente Bothrops jararaca fêmea após tratamento com reserpina e agonistas de adrenoceptores alfa e beta.

Figura 20 - Regulação da síntese das proteínas citoplasmáticas pela inervação noradrenérgica, identificadas na glândula de veneno da serpente Bothrops jararaca.

Figura 21 - Síntese de ATP sintase mitocondrial-símile é regulada pela inervação noradrenérgica na glândula de veneno da serpente Bothrops jararaca.

Figura 22 - Número de espécies de toxinas identificadas como proteínas secretadas na glândula de veneno da serpente Bothrops jararaca. 70

Figura 23 - Toxinas identificadas na glândula de veneno da serpente Bothrops jararaca estimuladas pela inervação noradrenérgica.

Figura 24 - Perfil proteico dos extratos de glândulas acessórias das serpentes Bothrops jararaca durante o ciclo de produção de secreção.

Figura 25 - Distribuição subcelular das proteínas identificadas nas glândulas acessórias de serpentes Bothrops jararaca durante o ciclo de produção de secreção. 76

Figura 26 - Número de espécies de proteínas identificadas na glândula acessória da serpente Bothrops jararaca que tiveram suas sínteses alteradas durante o ciclo de produção de secreção. .. 77

Figura 27 - Número de proteínas secretadas identificadas na glândula acessória da serpente Bothrops jararaca. 


\section{LISTA DE TABELAS}

Tabela 1- Protocolo de focalização isoelétrica utilizado para fitas de $18 \mathrm{~cm}$........................35

Tabela 2- Análise densitométrica das bandas dos extratos de glândulas acessórias de serpentes Bothrops jararaca sem extração de veneno e $(0$ dia $)$ e glândulas acessórias 4 e 7 dias após a extração de veneno. 75 
1 INTRODUÇ̃̃O

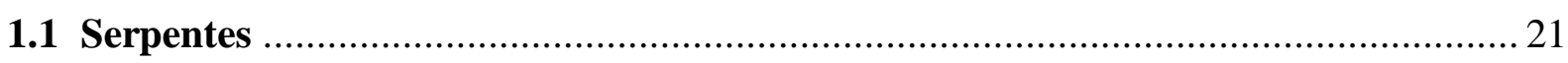

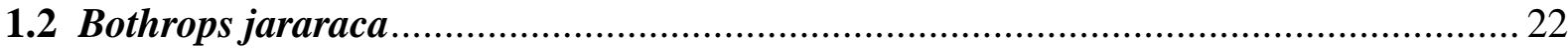

1.3 Aparelho glandular de veneno da serpente Viperidae .............................................. 23

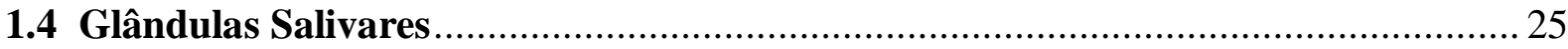

1.5 Mecanismos de produção de veneno pela glândula principal de veneno …………... 28

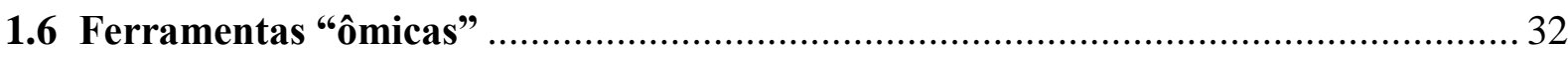

2 OBJETIVOS

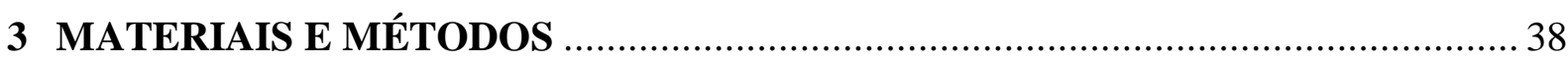

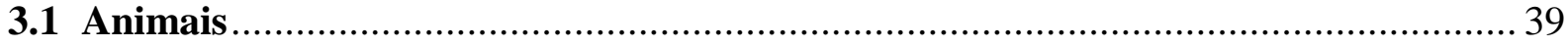

3.2 Glândulas de veneno e glândulas acessórias ……………………………………....... 39

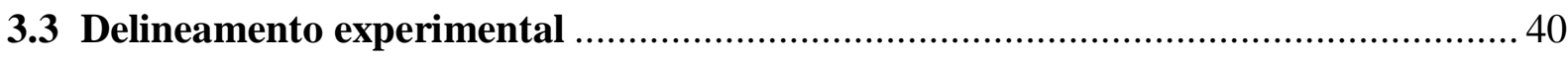

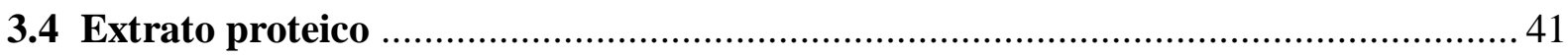

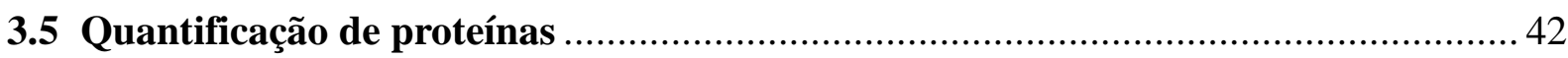

3.6 Análise proteômica da glândula de veneno de Bothrops jararaca …………………... 42

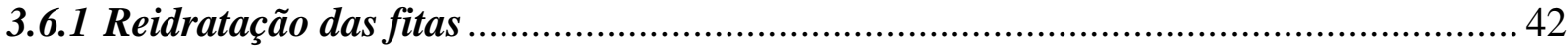

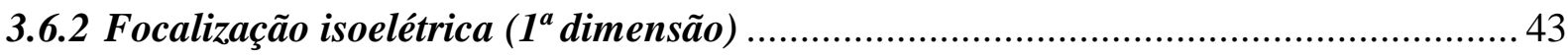

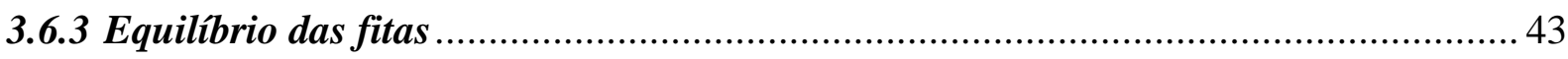

3.6.4 Eletroforese em gel de SDS-poliacrilamida (2 ${ }^{a}$ dimensão) ........................................ 43

3.6.5 Análise das imagens ............................................................................................ 44

3.7 Análise proteômica da glândula acessória de Bothrops jararaca …………………...... 44

3.7.1 Eletroforese em gel gradiente de SDS-poliacrilamida (1-DE).................................... 44

3.8 Identificação das proteínas das glândulas de veneno e acessória …………………..... 45

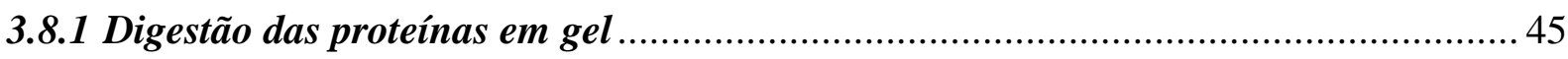

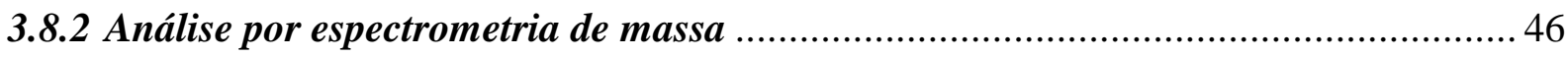

3.8.3 Ionização e dessorção a laser assistida por matriz em tempo de voo/tempo de voo

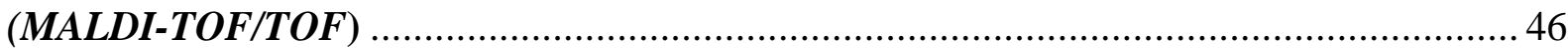

3.8.4 Nanocromatografia acoplada ao espectrômetro de massas de alta resolução

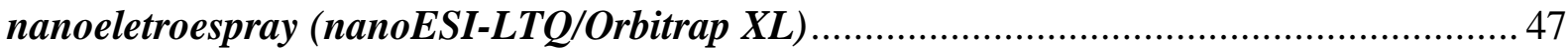

3.8.5 Analise dos dados pelo software PEAKS ................................................................. 48

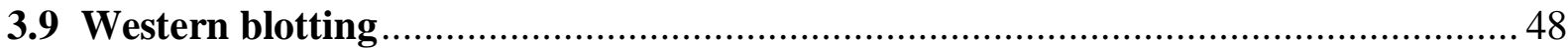

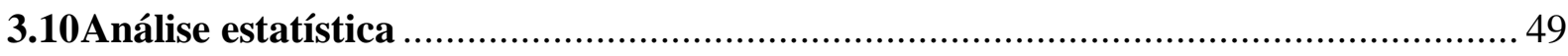

4 RESULTADOS 
4.1 Síntese proteica em glândulas de veneno durante o ciclo de produção de veneno.... 51 4.1.1 Identificação das proteínas da glândula de veneno durante o ciclo de produção de veneno

4.2 Confirmação das proteínas identificadas cujas sínteses foram reguladas durante o ciclo de produção de veneno

4.3 Síntese proteica em glândulas de veneno reguladas pela inervação noradrenérgica 63 4.3.1 Identificação das proteínas da glândula de veneno dos quais as sínteses são reguladas pela inervação noradrenérgica

4.4 Perfil eletroforético da glândula acessória durante o ciclo de produção de secreção 72

4.5 Identificação das proteínas da glândula de acessória 75

5 DISCUSSÃO. 80

5.1 Síntese de proteínas no ciclo de produção de veneno. 81

5.2 Participação da inervação noradrenérgica regulando a síntese de proteínas na glândula de veneno.

5.3 Síntese de proteínas da glândula acessória durante o ciclo de produção de veneno. 91

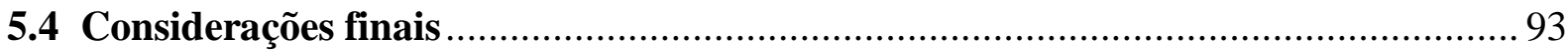

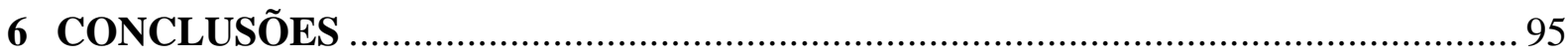

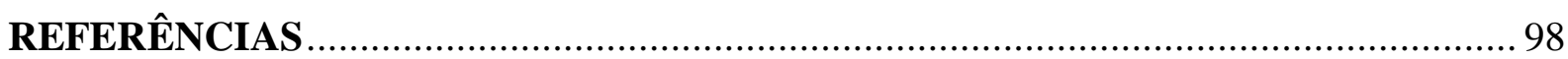

APÊNDICE A- Proteínas identificadas dos spots específicos de gel 2-DE das glândulas de veneno da serpente Bothrops jararaca no estágio quiescente.

APÊNDICE B - Proteínas identificadas dos spots específicos do gel 2-DE das glândulas de veneno da serpente Bothrops jararaca no estágio ativado 4 dias após a extração de veneno.

121

APÊNDICE C - Proteínas identificadas de spots específicos de gel 2-DE das glândulas de veneno da serpente Bothrops jararaca no estado ativado 7 dias após a extração de veneno.130 APÊNDICE D - Proteínas identificadas de spots específicos de gel 2-DE das glândulas de veneno da serpente Bothrops jararaca tratadas com reserpina durante 4 dias.

APÊNDICE E - Proteínas identificadas de spots específicos de gel 2-DE das glândulas de veneno da serpente Bothrops jararaca tratadas com reserpina, fenilefrina e isoprenalina durante 4 dias.

APÊNDICE F - Proteínas da glândula acessória da serpente Bothrops jararaca que não sofreu extração de veneno identificadas através do nanoESI-LTQ/Orbitrap XL.....

APÊNDICE G - Proteínas da glândula acessória da serpente Bothrops jararaca 4 dias após a extração de veneno identificadas através do nanoESI-LTQ/Orbitrap XL.

APÊNDICE H - Proteínas da glândula acessória da serpente Bothrops jararaca 7 dias após a extração de veneno através do nanoESI-LTQ/Orbitrap XL. 


\section{INTRODUÇÃO}




\subsection{Serpentes}

As serpentes são animais vertebrados que pertencem à classe dos répteis e a ordem Squamata. As serpentes estão organizadas em dois grupos principais: Scolecophidia (Cobrascegas) com aproximadamente 370 espécies e Alethinophidia ou serpentes típicas com aproximadamente 2700 espécies (VIDAL; HEDGES, 2009).

As serpentes do grupo Scolecophidia são pequenas e não têm veneno. Já o grupo Alethinophidia tem uma maior diversidade, compreende as boas, pythons e caenophidians. Todas as serpentes venenosas são encontradas no grupo Caenophidea (VIDAL; HEDGES, 2009), que incluem a superfamília Acrochordoidea de serpentes aquáticas e a superfamília Colubrodeia de serpentes avançadas, sendo a mais diversificada e é composta por quatro famílias: Colubridae, Atractaspididae, Elapidae e Viperidae.

À família Viperidae, tradicionalmente, é atribuída três subfamílias: Viperinae, Azemiopinae e Crotalinae. Os representantes da subfamília Crotalinae apresentam uma característica própria e exclusiva, a fosseta loreal. A fosseta loreal é um órgão termorregulador localizado ligeiramente abaixo da linha que separa o olho da narina, um de cada lado da cabeça. Este órgão é revestido por epitélio termo sensível que capta delicadas variações de temperatura do ambiente, permitindo a serpente formar imagem infravermelha, juntamente com a luminosa (FRANCO, 2003).

A subfamília Crotalinae possui 21 gêneros e 172 espécies, dos quais 4 gêneros e 23 espécies ocorrem no Brasil. As serpentes peçonhentas no Brasil são consideradas de importância medica e encontram-se classificadas nos gêneros Bothrops (Wagler 1824), Crotalus (Linnaeus 1758), Lachesis (Daudin 1803) e Micrurus (Wagler 1824) (ARAÚJO et al., 2003; BRASIL, 1998). O gênero Bothrops representa o grupo mais importante de serpentes peçonhentas, com mais de 60 espécies encontradas em todo território brasileiro (incluindo os gêneros Bothriopsis e Bothrocophias) (BRASIL, 2009).

Os gêneros Bothrops, Bothriopsis e Bothrocophias recentemente receberam nova classificação com base em evidências morfológicas e moleculares. Nessa nova classificação proposta por Fenwick et al. (2009) 11 espécies de serpentes anteriormente incluídas no gênero Bothrops foram alocadas em Bothropoides, porém para esse trabalho optamos por manter a nomenclatura tradicional e amplamente aceita entre a comunidade científica.

Em abril de 2009 os acidentes por animais peçonhentos foram incluídos na lista de Doenças Tropicais Negligenciadas da Organização Mundial da Saúde (OMS) por 
representarem um problema de saúde publica em virtude de sua alta frequência e gravidade (ACADEMIA BRASILEIRA DE CIÊNCIAS, 2010).

No Brasil, os envenenamentos ofídicos causados pelas serpentes do gênero Bothrops são os mais importantes devido à alta frequência de acidentes. As serpentes desse gênero são responsáveis por 72,6\% dos acidentes ofídicos que ocorrem no Brasil (BRASIL, 2009).

\subsection{Bothrops jararaca}

A serpente Bothrops jararaca (WIED, 1984), pertence à família Viperidae, tem o nome popular de jararaca ou jararaca-preguiçosa (Figura 1).

Esta serpente apresenta uma coloração muito variável, desde tons castanhos claros até coloração quase completamente preta. Ela é ágil, tem grande capacidade adaptativa ocupando áreas silvestres, agrícolas, suburbanas e até urbanas. Trata-se da espécie mais comum da região sudeste, habitando desde o sul da Bahia até o Rio Grande do Sul (BRASIL, 2009; CAMPBELL; LAMAR, 2004; MELGAREJO, 2003). Esta espécie é ativa principalmente no período crepuscular e noturno, podendo apresentar alguma atividade diurna, em geral associada à termorregulação comportamental (MARQUES; SAZIMA, 2004; SAZIMA, 1988).

Figura 1 - Serpente adulta de Bothrops jararaca em atividade sobre o solo.

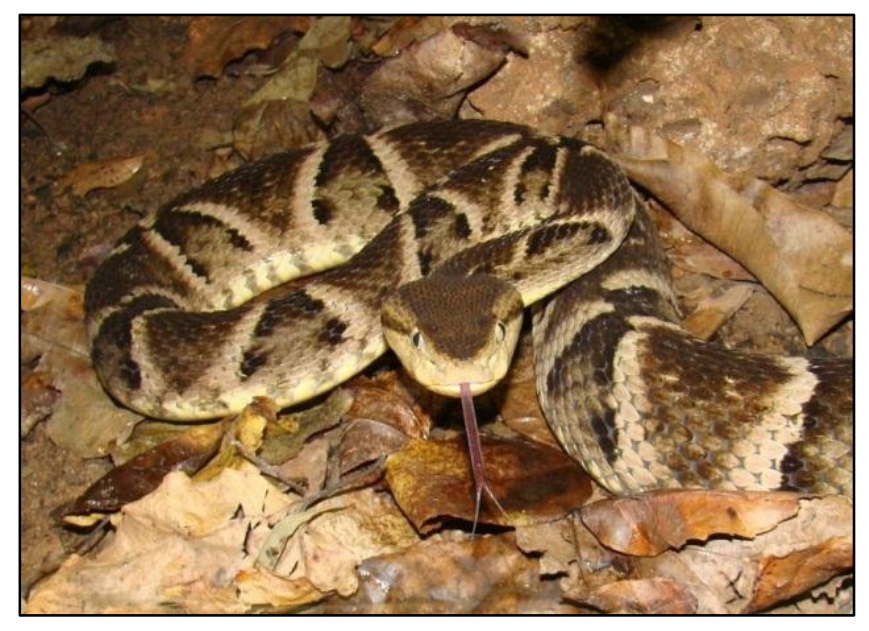

Fonte: Fotografada por Branco (2001) ${ }^{1}$.

\footnotetext{
${ }^{1}$ BRANCO, Enio. 2001.
} 
Uma das principais características da família Viperidae é a presença de um aparelho inoculador de veneno altamente especializado e eficiente para captura de presas. A dentição destas serpentes é do tipo solenoglifodonte, isto é, possuem um par de dentes maxilares extremamente grandes, pontiagudos com um canal interno onde o veneno é excretado. A dentição e a cinética craniana estão associadas a um mecanismo complexo que permite uma grande abertura bucal, facilitando assim o posicionamento do dente em relação à presa (GOMES; POURTO, 1993), (Figura 2).

Figura 2 - Crânio e mandíbula de serpente com dentição solenoglifodonte.

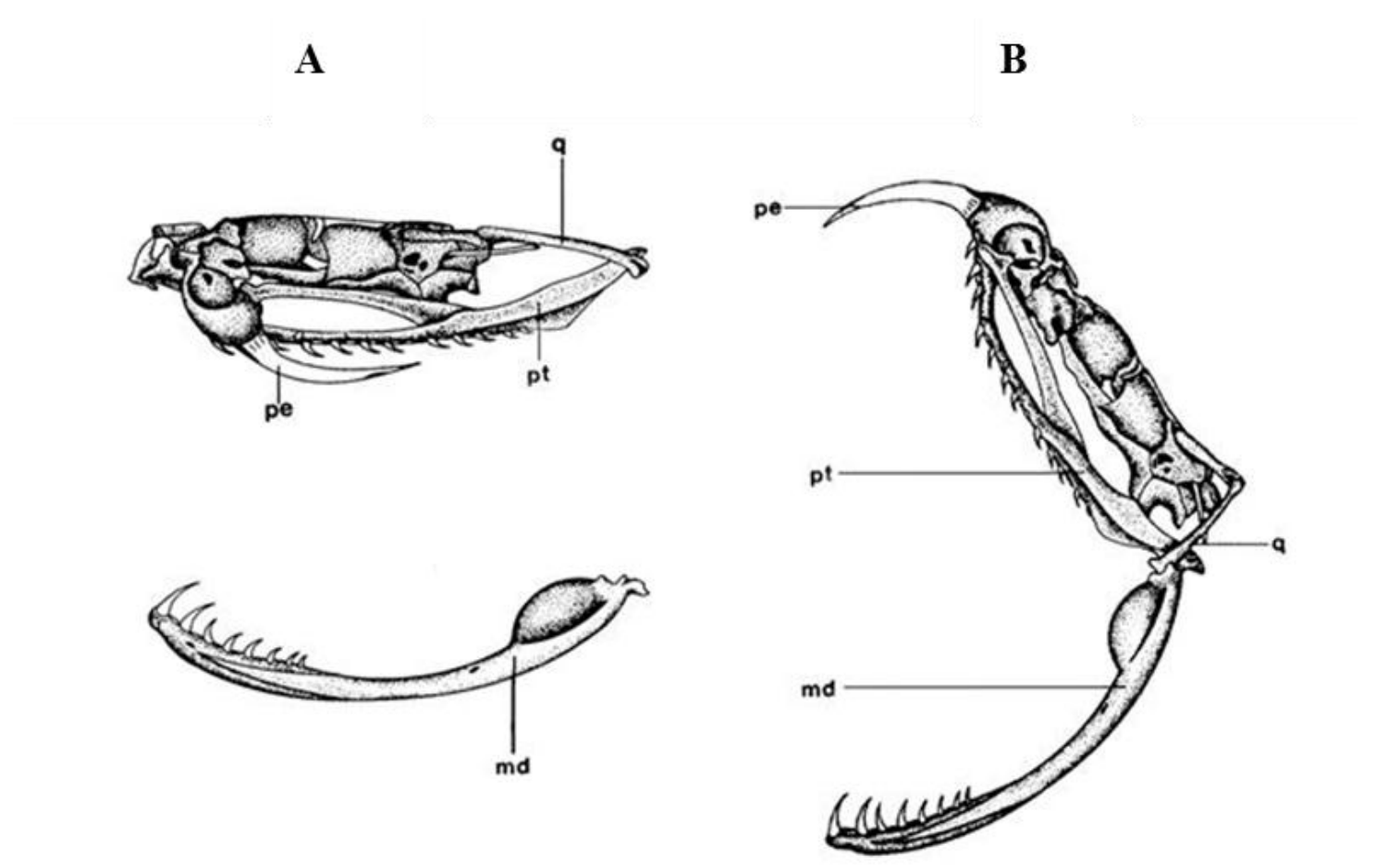

A: visão lateral do crânio com mandíbula fechada. B: Crânio e mandíbula em posição de abertura bucal máxima. pe: presa, pt: pterigoide, q: quadrado, md: mandíbula.

Fonte: Gomes e Puorto, 1993.

\subsection{Aparelho glandular de veneno da serpente Viperidae}

Entre as serpentes peçonhentas do Brasil, a mais bem estudada quanto à estrutura do aparelho glandular de veneno e a biossíntese da peçonha são as Viperidae. A serpente Bothrops jararaca possui um aparelho glandular de veneno altamente especializado composto por quatro regiões distintas: a glândula principal de veneno, a glândula acessória, o ducto 
primário e o ducto secundário que se conecta com o canal do dente inocular de veneno (GOMES; PUORTO, 1993) (Figura 3).

Figura 3 - Aparelho glandular de veneno da serpente Bothrops jararaca.

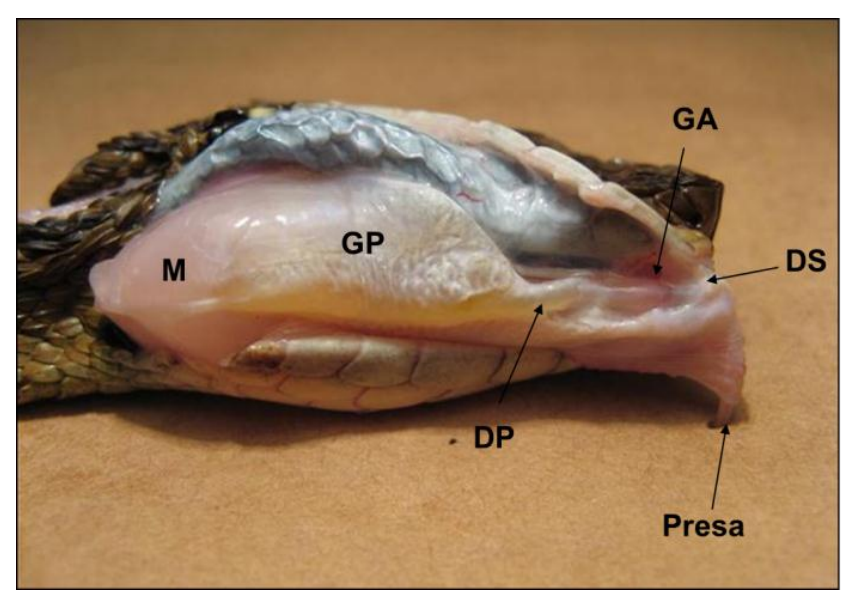

M: músculo compressor da glândula; GP: glândula principal de veneno; DP: ducto primário; GA: glândula acessória; DS: ducto secundário.

Fonte: Fotografado por Hortêncio (2006) ${ }^{2}$.

As glândulas de veneno de serpentes são glândulas exócrinas presentes na cavidade oral que evoluíram a partir de glândulas salivares de ancestrais não venenosos e a sua principal função é secretar veneno para facilitar a apreensão e digestão da presa (KARDONG, 1982; ZAGO, 1971).

A glândula principal de veneno provavelmente evoluiu a partir de estruturas salivares especializadas do lábio superior, como a glândula de Duvernoy, e o músculo compressor da glândula derivado da musculatura temporal anterior. $\mathrm{O}$ aparelho glandular de veneno está localizado na região temporal, um em cada lado da cabeça, logo atrás dos olhos e diretamente abaixo do músculo compressor. A glândula de veneno apresenta um formato triangular e alongado, com a parte mais alongada voltada para a região anterior da cabeça (MELGAREJO, 2003).

A glândula principal de veneno está envolvida por tecido conjuntivo e é formada por epitélio secretor tubular ramificado, onde se encontram pelo menos quatro tipos celulares: células epiteliais secretoras, a mais abundante na glândula (79\%), células ricas em mitocôndrias (2\%), células horizontais (10\%) e células escuras (9\%) (MACKESSY, 1991). Uma característica importante das glândulas de veneno de serpentes Viperidae é a estocagem

\footnotetext{
${ }^{2}$ HORTÊNCIO, Thiago M. A. São Paulo, 2006.
} 
do produto de secreção no lumen principal, diferindo das glândulas de serpentes da família Elapidae e de mamíferos, nas quais o produto é estocado em vesículas secretoras intracitoplasmáticas (JAMIESON; PALADE, 1967a, b; KOCHVA, 1978).

Duas estruturas presentes no aparelho glandular de veneno pouco estudadas são as glândulas acessórias e o ducto primário e ainda há controvérsias se as secreções liberadas por estas regiões podem modificar o veneno formado. Sabe-se que a luz da glândula principal de veneno conecta-se ao ducto primário e este forma uma alça e passa no interior da glândula acessória (KOCHVA; GANS, 1966). A glândula acessória é uma estrutura oval que envolve o ducto primário comprimindo-o (KOCHVA, 1978).

Recentemente, um estudo morfológico da glândula acessória da Bothrops jararaca mostrou que esta glândula possui um epitélio secretor simples com seis tipos celulares na região anterior: dois tipos de células secretoras, células ricas em mitocôndria que não possuem secreção, células horizontais, células basais e células escuras e um epitélio simples com somente dois tipos celulares na região posterior: células seromucosas e células horizontais. Este estudo também mostrou que as células secretoras da glândula acessória possuem uma exocitose tardia, 4 dias após a extração de veneno e assim como a glândula principal de veneno, possui um longo ciclo de produção e secreção. Devido à secreção tardia, foi sugerido que a secreção da glândula acessória não participa da formação do veneno total da serpente Bothrops jararaca (SAKAI; CARNEIRO; YAMANOUYE, 2012).

O ducto primário da serpente Bothrops jararaca apresenta um epitélio pseudoestratificado com células secretoras colunares apresentando vesículas com diferentes eletrodensidades, células ricas em mitocôndrias, células escuras, células basais e células horizontais. A análise morfológica mostrou que o ducto primário também possui um longo ciclo de produção e secreção e que esta secreção liberada pode participar do veneno total e pode ser que esta secreção seja o motivo das controvérsias existentes na literatura (SAKAI, 2011).

\subsection{Glândulas Salivares}

Relacionadas com as glândulas de veneno, as glândulas salivares são glândulas exócrinas que estão localizadas na cavidade oral e tem como principal função a síntese e secreção de saliva. Os três pares de glândulas salivares maiores em mamíferos que incluem a glândula submandibular, parótida e sublingual são responsáveis por $90 \%$ da saliva total. A saliva é composta por fluídos, eletrólitos, proteínas e mucinas (PROCTOR; CARPENTER, 
2007). A secreção da saliva é estimulada por vários fatores como a presença de alimentos na boca ou estímulos olfativos. Estas mensagens são transmitidas às glândulas salivares via sistema nervoso autonômico. As glândulas salivares recebem inervações simpáticas e parassimpáticas que estão diretamente envolvidas na secreção glandular. Ambos os impulsos simpáticos e parassimpáticos agem nas células secretoras simultaneamente. O estímulo via parassimpático provoca secreção de saliva abundante, muito aquosa, com pouca matéria orgânica, enquanto o estímulo via simpático promove a secreção de saliva mais viscosa rica em moléculas orgânicas (SCHNEYER et al., 1972).

A estimulação simpática que age nas células, frequentemente não causa mobilização de fluidos e tende a modular a composição da saliva pelo aumento da exocitose das vesículas secretoras das células salivares e induz contração das células mioepiteliais, de modo que a contração dessas células leva à liberação da saliva (GARRETT; THULIN, 1975; GARRET et al., 1987; PROCTOR; CARPENTER, 2007).

Os principais fatores regulatórios que demonstraram ter um papel na regulação das secreções das glândulas salivares são os neurotransmissores liberados por inervação simpática e parassimpática. Esses neurotransmissores são os primeiros mensageiros envolvidos na regulação celular da exocitose. Entre os neurotransmissores que ativam as células secretoras salivares, os principais são a acetilcolina, secretada pelos nervos parassimpáticos e a noradrenalina, secretada pelos nervos simpáticos, além de vários neuropeptídios (BAUM, 1987; EKSTROM, 1987; EKSTROM et al., 1988; WRIGTH; LUEBKE, 1989).

A noradrenalina liberada pela estimulação simpática estimula a secreção das proteínas salivares através da sua interação com receptores adrenérgicos.

Os receptores adrenérgicos são membros da superfamília de receptores acoplados a proteína $G$ e são classificados em adrenoceptores $\alpha$ e adrenoceptores $\beta$. Posteriormente através de evidencias farmacológicas e moleculares mostrou-se que havia outras classes de receptores denominadas de adrenoceptores $\alpha_{1}, \alpha_{2}$ e $\beta$, no qual foram subdivididos em três

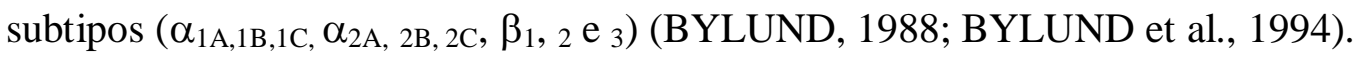

Todos os três subtipos de adrenoceptores $\alpha_{1}$ estão acoplados à proteína Gq/11, que está envolvida na ativação da enzima fosfolipase $C$, que participa da formação de segundos mensageiros. A fosfolipase $\mathrm{C}$ ativada hidrolisa o bifosfato de fosfatidilinositol (PIP2) presente na membrana em trifosfato de inositol $\left(\mathrm{IP}_{3}\right)$ e diacilglicerol (DAG) (GRAHAM et al., 1996; VARMA; DENG, 2000). O segundo mensageiro hidrossolúvel, $\mathrm{IP}_{3}$, migra pelo 
citosol e se liga a receptores específicos de $\mathrm{IP}_{3}$ no retículo endoplasmático e mitocôndrias, promovendo a liberação do íon $\mathrm{Ca}^{+2}$ no citosol. O DAG fica associado à membrana plasmática, tem a função de ativar a proteína cinase C (PKC) (XIAO et al., 2006).

$\mathrm{O}$ adrenoceptor $\beta$ está acoplado à proteína Gs, que quando ativada estimula a via de sinalização clássica, envolvendo a ativação de adenilil ciclase, resultando no aumento da concentração de monofosfato de adenosina cíclica (AMPc). O aumento na concentração de AMPc intracelular culmina na ativação da proteína cinase dependente de AMPc (PKA). A ligação do AMPc induz mudanças conformacionais que resultam na ativação da PKA, responsável pela fosforilação de proteínas efetoras (XIAO et al., 2006).O adrenoceptor $\alpha_{2}$ está acoplado a proteína Gi, que inibe a atividade da enzima adenilil ciclase, regulando diversas respostas celulares.

Nas glândulas salivares os adrenoceptores do tipo $\alpha_{1}$ e $\beta_{1}$, promove uma secreção viscosa rica em mucinas (BAUM, 1993; BAUM; WELLNER, 1999; PELUSO et al., 2007; QUISSEL; BARZEN, 1980). A clássica via de sinalização acoplada ao adrenoceptor $\alpha_{1}$ que regula a secreção de fluidos, eletrólitos, amilase e mucinas envolve a formação do 1,4,5trifosfato de inositol, que aumenta liberação de cálcio intracelular, modulando a exocitose de proteínas e mucinas (KLEIN, 2002; QUISSELL et al., 1992; QUISSELL; BARZEN; DEISHER, 1993).

A ativação do adrenoceptor $\beta$ tem uma participação importante na expressão e secreção de proteínas e no desenvolvimento pós-natal em glândulas salivares (BARKA, 1990; YEH et al., 2005). Ativação dos adrenoceptores $\beta$ também leva à produção de AMPc e à ativação de proteínas cinases dependentes de AMPc, ativando várias cascatas de sinalização tais como as MAPKs (QUISSELL et al., 1992; YEH et al., 2012). Os subtipos $\beta_{1}$ e $\beta_{2}$ são expressos na glândula submandibular de coelhos, sendo que o subtipo $\beta_{1}$ é predominante e participa da regulação da secreção de saliva, especialmente na síntese e secreção de proteínas (BAUM; WELLNER, 1999; LI et al., 2006). Em glândulas parótidas de ratos o subtipo $\beta_{1}$ é predominante e provavelmente é o responsável por iniciar a cascata de sinalização que leva à proliferação celular, já o subtipo $\beta_{2}$ parece ser essencial em fases posteriores no desenvolvimento e proliferação das glândulas salivares (YEH et al., 2012). 


\subsection{Mecanismos de produção de veneno pela glândula principal de veneno}

A produção de veneno inicia-se após a redução do conteúdo estocado no lumen da glândula, seja após uma picada ou a extração manual de veneno. O inicio do ciclo de produção de veneno é marcado por mudanças morfológicas e bioquímicas nas células secretoras. As glândulas de veneno no estado quiescente, que não sofreram extração de veneno por um longo período, de um a dois meses, estão repletas de veneno. No estado quiescente, as células secretoras, responsáveis pela produção e secreção de veneno, estão na forma cuboide, as cisternas do Retículo Endoplasmático Rugoso (RER) estão estreitas e paralelas e o aparelho de Golgi está quiescente. Após a extração de veneno, a quantidade de veneno no lumen diminui e as células secretoras passam para a forma colunar, as cisternas do REG se expandem e o veneno é sintetizado (BDOLAH, 1979; BEN-SHAUL; LIFSHITZ; KOCHVA, 1971; CARNEIRO et al., 1991; DE LUCCA et al., 1974; KOCHVA, 1971; KOCHVA, 1978; MACKESSY, 1991; ORON; BDOLAH, 1973; ROTENBERG; BAMBERGER; SALOMÃO, 1991; SCHAEFFER et al., 1972a, b; ZAGO, 1971). O pico máximo da atividade sintética ocorre aproximadamente quatro dias após a extração do veneno, neste momento as células secretoras alcançam a altura máxima (CARNEIRO et al., 1991; DE LUCCA et al., 1974; KOCHVA, 1987; KOCHVA, 1978) (Figura 4). Apesar das glândulas de veneno estarem ativadas nesse estágio do ciclo, poucas vesículas são encontradas nas células secretoras, pois todo material sintetizado é exocitado e estocado no lumen glandular. Após este período, as células secretoras diminuem de tamanho e gradualmente a célula assume a organização do estado quiescente (BEN-SHAUL; LIFSHITZ; KOCHVA, 1971; ORON; BDOLAH, 1973). O ciclo completo de produção de veneno dura de 30 a 50

dias, sendo significativamente mais longo quando comparado ao ciclo de produção de proteínas em glândulas exócrinas de mamíferos (AMSTERDAM; OHAD; SHRAMM, 1969; JAMIESON; PALADE, 1967a, b). 
Figura 4 - Representação esquemática das mudanças morfológicas das células secretoras da glândula de veneno da serpente Vipera palestinae durante o ciclo de produção de veneno.

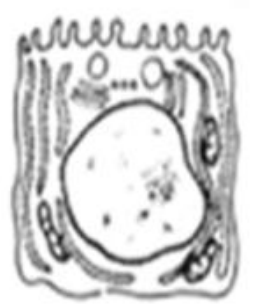

$3 \mathrm{~h}$
$24 \mathrm{~h}$

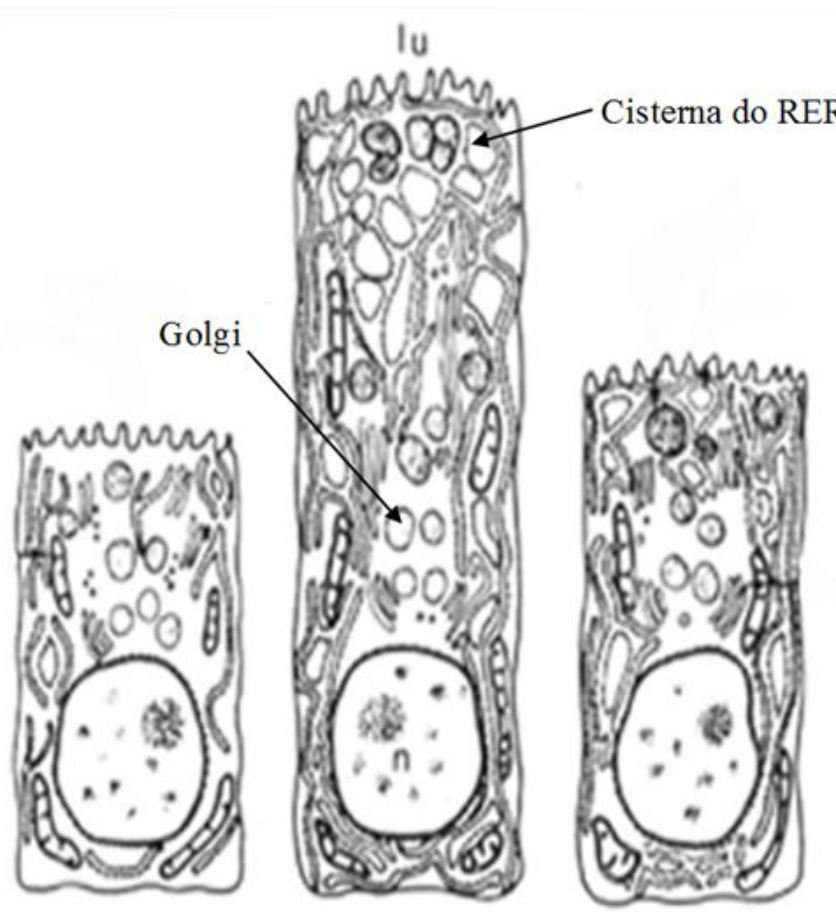

$4 d$

$8 \mathrm{~d}$

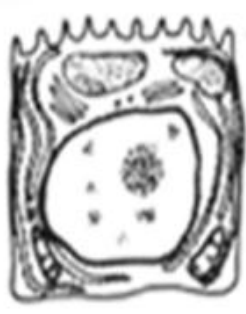

$50 d$

Retículo endoplasmático ruguso (RER).

Fonte: Adaptado de Ben-Shaul, Lifshitz e Kochva, 1971.

O perfil de atividade sintética tem sido baseada na análise da síntese de RNAm ou de proteínas. Por exemplo, Rotenberg, Bamberger e Kochva (1971) mostraram através da incorporação ${ }^{32} \mathrm{P}$ no RNA total de glândulas de veneno de Vipera palestinae que a extração de veneno ativa o epitélio secretor da glândula de veneno e resulta em uma alta taxa de síntese de RNA entre o primeiro e quarto dia após a extração de veneno. Já em relação ao acúmulo de proteínas Oron e Bdolah (1978) mostraram que no primeiro dia após a extração de veneno, a maior parte das proteínas sintetizadas são provavelmente proteínas estruturais e quando as células atingem a capacidade sintética máxima a maioria das proteínas sintetizadas é do veneno.

A regulação ou controle da síntese das proteínas do veneno parece envolver um componente físico, através de variações na pressão intraluminal sobre as células epiteliais da glândula, a qual varia de acordo com o volume de veneno presente no lumen (KOCHVA, 1978), bem como um componente neuronal envolvendo a inervação simpática através da 
estimulação de receptores $\alpha$ - e $\beta$-adrenérgicos (KERCHOVE et al., 2004; KERCHOVE et al., 2008; YAMANOUYE et al., 1997; YAMANOUYE et al., 2000; ZABLITH, 2007).

Os mecanismos envolvidos na regulação da síntese e secreção de toxinas pela glândula de veneno são pouco conhecidos. No entanto, nesta última década, o grupo de pesquisa coordenado por Yamanouye tem mostrado a importância da inervação noradrenérgica na produção e secreção de veneno em serpentes Bothrops jararaca.

Para desvendar esse papel da inervação noradrenérgica a utilização de ferramentas farmacológicas como a reserpina tem sido amplamente utilizada. A reserpina é uma droga simpatolítica, que bloqueia o transporte de noradrenalina para as vesículas sinápticas através de sua ligação à proteína transportadora (MARTINEZ-OLIVARES et al., 2006). A noradrenalina vai ser acumulada no citoplasma, onde é degradada pela enzima monoamina oxidase (MAO). Portanto, o nível de noradrenalina cai nos tecidos e ocorre o bloqueio da transmissão simpática.

Em glândulas de veneno, foi possível observar o bloqueio da atividade noradrenérgica, uma vez que reserpina foi capaz de paralisar a produção e secreção de veneno em glândulas ativadas por meio da extração de veneno e ambos os adrenoceptores $\alpha$ e $\beta$, participam deste processo. A administração crônica de fenilefrina (agonista do adrenoceptor $\alpha$ ) e isoprenalina (agonistas de adrenoceptor $\beta$ ) foram capazes de reverter à ação de reserpina, restaurando a síntese proteica do veneno, mas apenas a fenilefrina foi capaz de restaurar o processo de secreção das proteínas do veneno (YAMANOUYE et al., 1997).

Os adrenoceptores $\beta$ estão acoplados à proteína Gs, visto que sua estimulação leva a um aumento na concentração de AMPc. Além disso, a estimulação dos adrenoceptores $\beta$ ativa o influxo de cálcio via canais ativados por voltagem (VOC) e ativados por receptores (ROC), além de mobilizar cálcio de estoques sensíveis a tapsgargina (ZABLITH, 2007). Vale ressaltar que o aumento de AMPc após estimulação dos adrenoceptores $\beta$ só ocorre em células no estado quiescente (glândulas que não sofreram extração de veneno) e não no seu estágio máximo de ativação (4 dias após a extração de veneno) e o aumento da concentração citosólica de cálcio é significativamente maior em células quiescentes (YAMANOUYE et al., 2000; ZABLITH, 2007).

Os adrenoceptores $\alpha$ são do subtipo $\alpha_{1 \mathrm{D}}$ e estão acoplado à proteína $\mathrm{Gq}$, visto que sua estimulação ativa a fosfolipase C (PLC) levando à hidrólise do $\mathrm{PIP}_{2}$, com a consequente produção do $\mathrm{IP}_{3}$ e DAG, promovendo a liberação de cálcio dos estoques intracelulares sensíveis a tapsgargina e ativação de PKC, respectivamente. Além disso, esses receptores 
ativam a cascata da cinase ativada por mitógenos ERK1/2, sendo que a etapa inicial dessa ativação é via PKC (KERCHOVE, 2004; KERCHOVE et al., 2008). Esses receptores quando estimulados são prontamente dessensibilizados, sendo essa dessensibilização de longa duração (30 dias) (KERCHOVE et al., 2004).

A descoberta de que adrenoceptores $\alpha_{1}$ e $\beta$ sofrem dessensibilização por um longo período, logo após a sua ativação, mostrou in vivo, a importância da estimulação desses adrenoceptores para o desencadeamento do ciclo de produção de veneno (KERCHOVE et al., 2004; YAMANOUYE et al., 2000; ZABLITH, 2007).

Posteriormente, estudos sobre a sinalização intracelular desencadeada pela estimulação dos adrenoceptores permitiu concluir que a noradrenalina é importante para a ativação da glândula de veneno (KERCHOVE et al., 2008; LUNA et al., 2009). A ativação desses receptores leva a ativação de fatores de transcrição tais como NFkB e AP-1 que regulam a síntese de proteínas da glândula de veneno, essenciais para a ativação da mesma. Este estudo mostrou ainda que a extração de veneno promove mudanças no perfil proteico da glândula de veneno, sendo que as diferenças mais significativas foram 4 e 7 dias após a extração de veneno em serpentes fêmeas e machos, respectivamente. O tratamento com reserpina bloqueou essas mudanças e a administração concomitante de agonistas de adrenoceptores $\alpha$ e $\beta$ restaurou o efeito de reserpina, levando a ativação da glândula de veneno e consequentemente a produção de veneno (LUNA et al., 2009). As glândulas de veneno das serpentes Viperidae são glândulas orais exócrinas, assim como as glândulas salivares, e são capazes de secretar proteínas tóxicas (KOCHVA; GANS, 1970). Essas glândulas de veneno têm a característica de possuir um lumen central onde o veneno produzido é armazenado e um longo ciclo de produção de veneno que leva de 30 a 50 dias para se completar, estas fases incluem um estágio de ativação após a perda do veneno do lumen e um estágio quiescente quando o lumen está cheio de veneno (KOCHVA; GANS, 1970; KOCHVA, 1987; MACKESSY, 1991; WARSHAWSKY et al., 1973; YAMANOUYE et al., 2000), diferentemente das glândulas salivares que estão constantemente ativadas.

A importância da inervação parassimpática para produção de saliva é claramente demonstrada na xerostomia (falta de saliva) que pode ocorrer em resposta a várias condições, incluindo reações adversas a medicamentos, estresse e radioterapia (BROSKY, 2007; DANIELS; WU, 2000), ou ainda em patologias que causam disfunções das glândulas salivares como a síndrome de Sjögren que leva à deterioração da membrana mucosa da boca e garganta (VON BÜLTZINGSLÖWEN et al., 2007). Agonistas de colinoceptores, como a 
pilocarpina, têm sido utilizados no intuito de promover um aumento no fluxo de saliva e assim, melhorar os sintomas da xerostomia (BROSKY, 2007). Análise proteômica da saliva mostrou que a pilocarpina restaurou parcialmente a densidade e número de proteínas identificáveis na saliva de pacientes com Síndrome de Sjögren (PELUSO et al., 2007). Porém, não existem trabalhos mostrando a importância da estimulação simpática na melhoria dos sintomas da xerostomia.

As glândulas salivares, ao contrário das glândulas de veneno de serpentes Viperidae, estão constantemente ativadas dificultando o estudo dos mecanismos fisiológicos envolvidos na síntese e secreção desta glândula, contudo a glândula principal de veneno torna-se um bom modelo de estudo, uma vez que ela pode assumir dois estados de ativação: estado quiescente e estado ativado possibilitando assim estudar estes mecanismos passo a passo para um melhor entendimento sobre as patologias que afetam as glândulas salivares.

\subsection{Ferramentas "ômicas"}

Com o progresso da biologia molecular, está ocorrendo um grande interesse por métodos de análise em alta escala (OMICAS), no qual geram quantidades exorbitantes de dados que permitem identificar grandes redes regulatórias. No entanto, um sistema não é apenas um conjunto de genes e proteínas e suas propriedades não podem ser completamente compreendidas apenas desenhando um diagrama com suas interconexões, apesar deste diagrama ser um bom começo para se entender o funcionamento do sistema. Para estudar um sistema é necessário conhecer como suas partes, genes e proteínas se relacionam de um modo dinâmico durante uma determinada situação estudada, como cada parte se comporta nessa determinada situação e como a resposta de cada parte interfere na outra parte, assim ao final espera-se ter um diagrama dinâmico que explique como o sistema se comporta (KITANO, 2002).

O sequenciamento genômico e o consequente conhecimento da sequencia completa de todos os genes são contribuições importantíssimas para se estudar melhor os organismos vivos. Porém, estas informações não são suficientes para saber quais proteínas estão sendo realmente expressas na célula, num dado momento, numa determinada condição.

$\mathrm{Na}$ era pós-genômica, tem ficado evidente que além das informações obtidas pela análise do genoma, é preciso ter conhecimento, por exemplo, sobre quais proteínas estão realmente sendo expressas, quando e em quais níveis esta expressão ocorre e sobre as 
eventuais modificações pós-tranducionais. $\mathrm{O}$ fato de as células de um mesmo organismo ter o mesmo genoma, mas apresentarem as mais variadas funções e morfologias, produto de diferentes composições de proteínas expressas, ilustra a importância de estudar não só a sequencia dos genes, mas também a sua expressão para podermos compreender a suas funções biológicas (PANDEY; MANN, 2002). Desta forma, a proteômica, que é análise do conjunto de proteínas expressas em uma determinada célula ou tecido, num determinado momento, a partir do genoma, tornou-se uma ferramenta importante para conhecer o funcionamento celular.

A análise do proteoma é significativamente mais complicada do que o sequenciamento genômico. Estudos envolvendo proteoma incluem extração de proteínas, separação, quantificação e por último a identificação por espectrometria de massas (MS) e análises por bioinformática. A espectrometria de massas baseada no proteoma tornou-se uma poderosa ferramenta para análises qualitativas (presença/ausência) e quantitativas (intensidade de spots) de um grande número de proteínas.

As informações sobre o proteoma de uma amostra podem derivar da análise de proteínas intactas (proteômica top-down) ou de seus peptídeos (proteômica bottom-up). Na proteômica bottom-up, as proteínas de uma mistura são digeridas, e os peptídeos resultantes são analisados por MS. As limitações dessa estratégia podem estar na cobertura incompleta da sequência das proteínas, na perda das modificações pós-traducionais e nas degradações como resultado da digestão proteolítica. Já a análise top-down permite deduzir a estrutura primária da proteína e a maior parte das modificações pós-traducionais (WU et al., 2012). No entanto, essa estratégia é limitada pela energia de colisão necessária na fragmentação da proteína que é insuficiente para proteínas maiores que $50 \mathrm{kDa}$, ficando restrita sua aplicação à análise de proteínas purificadas (NESATYY; SUTER, 2008).

$\mathrm{Na}$ análise bottow-up de misturas complexas, são utilizados géis de eletroforese bidimensional (2-DE) ou cromatografia liquida. Atualmente a técnica de gel 2-DE é capaz de resolver um grande número de misturas complexas de proteínas, combinando a focalização isoelétrica e a massa molecular relativa de cada proteína, melhorando a identificação e a caracterização de diferentes isoformas de proteínas. O gel 2-DE tem um excelente poder de resolução de proteínas intactas ( 2000), embora seja um processo difícil para automatizar, trabalhoso e de baixa reprodutibilidade. No entanto, ainda é uma abordagem poderosa para diferenciar isoformas de proteínas e estados de modificações pós-traducionais, e deve continuar a servir bem neste papel (MOTOYAMA; YATES, 2008). A cromatografia liquida de fase reversa acoplada à espectrometria de massas em tandem (LC/MS/MS) foi 
desenvolvida para automação dos métodos de análise em larga escala e utiliza diferentes características das proteínas em colunas de propriedades distintas ou em uma única coluna bifásica. A fração eluída na primeira coluna é diretamente introduzida na segunda coluna, a qual pode ser diretamente acoplada ao espectrômetro de massas. Essa técnica, chamada de MudPIT (Multidimensional Protein Identification Technology), está inserida no contexto da proteômica shotgun, em que uma maior resolução dos proteomas é possível, facilitando a identificação das proteínas menos abundantes, frequentemente perdidas quando utilizados os géis (MOTOYAMA; YATES, 2008). A identificação de proteínas por meio da espectrometria de massas depende da digestão proteolítica que produz uma coleção de peptídeos que são ionizados por técnicas de ionização suave como ionização por eletro spray (ESI Electrospray ionization) e a ionização/dessorção a laser assistida por matriz (MALDI Matrix-assisted laser desorption ionization) (ROTILIO et al., 2012). Após a ionização, analisadores de massas detectam as relações massa/carga $(\mathrm{m} / \mathrm{z})$ e os espectros resultantes e relacionam a abundância dos fragmentos versus a relação $\mathrm{m} / \mathrm{z}$, os quais são então confrontados nos bancos de dados para a identificação das proteínas.

Os trabalhos publicados até o momento, utilizando a análise em larga escala das proteínas por meio da abordagem proteômica de serpentes do gênero Bothrops, tiveram como foco principal os constituintes do veneno (SERRANO et al., 2005; TASHIMA et al., 2012; VALENTE et al., 2009; ZELANIS et al., 2011). Entre os componentes frequentemente encontrados no proteoma de venenos das serpentes viperídeas neotropicais estão: metaloproteinases, disintegrinas, serinoproteinases, fosfolipases A2, lectinas tipo C-símile, peptídeos potenciadores de bradicinina, proteínas secretadas ricas em cisteínas (CRISP Cysteine rich secretory protein), fatores de crescimento como svVEGF (snake venom Vascular Endothelium Growth Factor) e svNGF (snake venom Nerve Growth Factor).

A estratégia de sequenciamento de bibliotecas de cDNA no intuito de se obter uma visão global da expressão gênica e da diversidade de toxinas nas glândulas de veneno das diferentes espécies é de extrema importância na toxinologia. Em relação às serpentes do gênero Bothrops existem diversos trabalhos utilizando a metodologia de análise transcriptômica por meio de ESTs (Expressed Sequence Tags). Junqueira-de-Azevedo e Ho (2002) foram os primeiros pesquisadores a explorar a diversidade de transcritos de glândula de veneno da espécie Bothrops insularis. Desde então, diversas espécies já tiveram os transcriptomas de glândula de veneno revelados, inclusive da Bothrops jararaca (CIDADE et al., 2006). 
Contudo, a despeito da funcionalidade da glândula principal de veneno pouco se conhece. Um estudo realizado recentemente analisou as modificações na expressão gênica durante o ciclo de produção e secreção de veneno da Bothrops jararaca e verificou que a expressão de transcritos celulares e de toxinas é semelhante ao longo dos 15 dias do ciclo de produção de veneno avaliado, sendo o pico máximo de expressão dos transcritos no segundo dia após o inicio do ciclo. Além disso, mostrou que o processo de transcrição de toxinas ocorre independente da ativação dos adrenoceptores $\alpha$ e $\beta$ e que a ativação dos adrenoceptores parece ser necessária para formação das vesículas secretoras. No entanto, este estudo teve como base a comparação com a biblioteca de cDNA de glândula de veneno coletada 4 dias após a extração de veneno (BASTOS, 2011).

Características importantes das proteínas contidas na glândula de veneno, no entanto, permanecem desconhecidas. Desta forma, a análise proteômica dos mecanismos celulares envolvidos no desencadeamento da síntese e secreção de veneno pelo aparelho da glandular de veneno da serpente Bothrops jararaca é importante para o conhecimento da funcionalidade desta glândula, bem como dar subsídios para um melhor entendimento sobre as patologias que afetam as glândulas salivares. 
2OBJETTVOS 
O objetivo geral deste estudo foi identificar as proteínas que são potencialmente importante para ativação da glândula principal de veneno e da glândula acessória da serpente Bothrops jararaca durante o ciclo de produção de veneno e as proteínas da glândula principal de veneno na qual a síntese é regulada pela inervação noradrenérgica. Para tanto, os seguintes objetivos específicos foram propostos:

- Analisar as proteínas das glândulas principal de veneno de serpentes fêmeas nos estágios quiescente e ativados 4 e 7 dias após a extração de veneno, através da técnica de eletroforese 2-DE;

- Analisar as proteínas que participam da ativação da glândula principal de veneno, cujas sínteses são reguladas pela estimulação dos adrenoceptores $\alpha$ e $\beta$, através da técnica de eletroforese 2-DE;

- Analisar o perfil proteico das glândulas acessórias de serpentes fêmeas que não sofreram extração de veneno e 4 e 7 dias após a extração de veneno e, através do gel de gradiente unidimensional;

- Identificar por espectrometria de massas as proteínas exclusivas da glândula principal de veneno nos diferentes estágios do ciclo de produção de veneno, bem como as proteínas nas quais as sínteses foram reguladas pela estimulação dos adrenoceptores $\alpha$ e $\beta$.

- Identificar por espectrometria de massas as proteínas da glândula acessória que estão presentes nos diferentes estágios analisados.

- Relacionar os grupos de proteínas identificadas com uma função conhecida e discutir sua participação na ativação da glândula de veneno. 
3 MATERIAIS E MÉTODOS 
Todos os ensaios realizados que evolveram as serpentes, inclusive as extrações de veneno, tiveram autorização prévia da Comissão de Ética no Uso de Animais do Instituto Butantan (CEUAIB, 555/2008), da Comissão de Ética em Experimentação Animal (CEEA) do Instituto de Ciências Biomédicas da Universidade de São Paulo ( $\mathrm{n}^{\circ}$ 138, nas fls. 74 do livro 2) e do Instituto Brasileiro do Meio Ambiente e dos Recursos Naturais Renováveis (IBAMA - processo nº 02001.005106/2008, Licença 01/2009).

\subsection{Animais}

As serpentes Bothrops jararaca fêmeas (WIED, 1824), de 100-400 g, foram fornecidas e classificadas pelo Laboratório de Herpetologia do Instituto Butantan. Essas serpentes foram tratadas segundo Breno et al. (1990) e mantidas em salas com condições ambientais controladas: fotoperíodo de 12 horas, temperatura entre $21{ }^{\circ} \mathrm{C}$ e $27{ }^{\circ} \mathrm{C}$ e umidade relativa de aproximadamente $65 \%$.

\subsection{Glândulas de veneno e glândulas acessórias}

As serpentes foram previamente anestesiadas com pentobarbital sódico $(30 \mathrm{mg} / \mathrm{kg}$, s.c.), decapitadas e em seguida as glândulas de veneno e as glândulas acessórias foram coletadas e dissecadas como demonstrado na Figura 5. Após a retirada das glândulas, estas foram pressionadas com o auxílio de uma pinça, para completa remoção do veneno do lumen. Utilizamos as glândulas de veneno e acessórias de serpentes fêmeas que não sofreram extração de veneno (glândulas quiescentes) e de serpentes que sofreram extração de veneno 4 e 7 dias antes do sacrifício (glândulas estimuladas) ou ainda de serpentes tratadas com reserpina $(20 \mathrm{mg} / \mathrm{kg}$, s.c. 24 horas antes da extração de veneno, seguido por injeções diárias de $5 \mathrm{mg} / \mathrm{kg}$, s.c. durante 4 dias). Algumas serpentes tratadas com reserpina receberam ainda uma dose única de isoprenalina e fenilefrina $(100 \mathrm{mg} / \mathrm{kg}$, s.c.), logo após a extração de veneno. A extração manual do veneno foi realizada de acordo com Belluomini (1968). 
Figura 5 - Remoção das glândulas de veneno e acessória da serpente Bothrops jararaca.

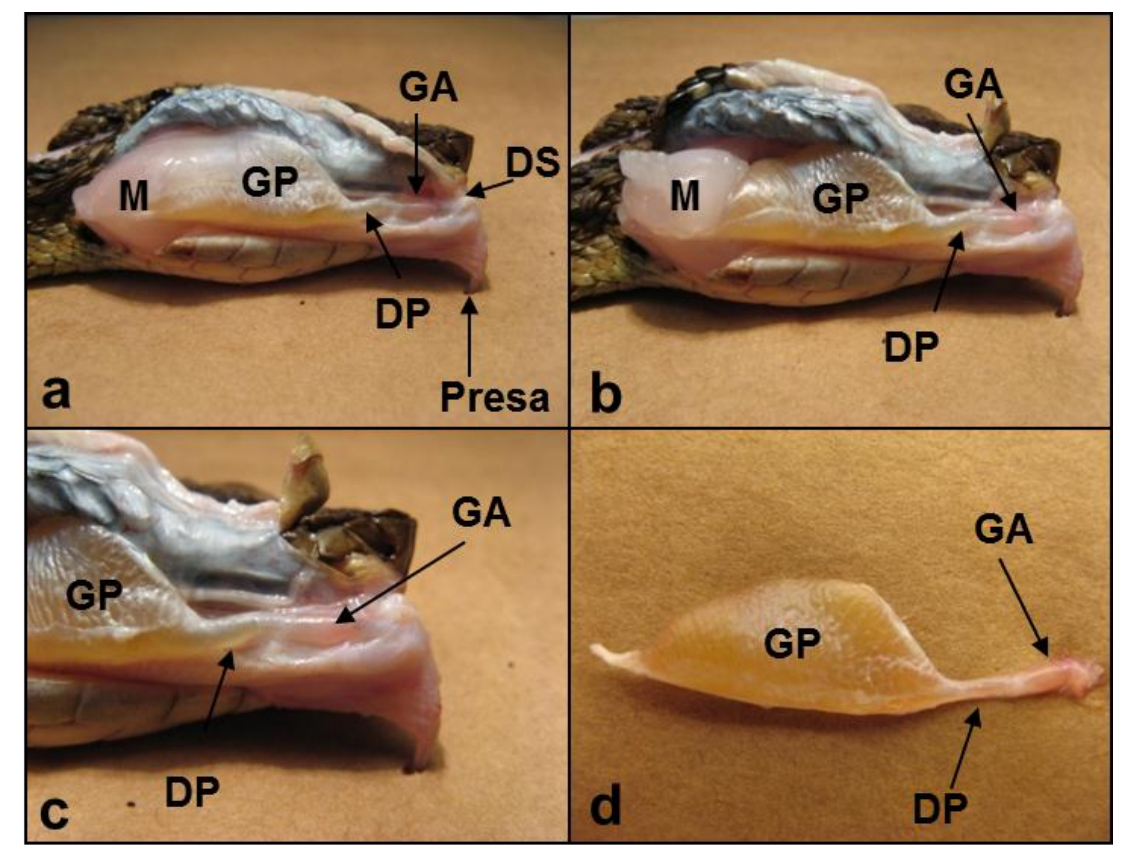

a. Glândula de veneno localizada na região temporal da cabeça; b. Dissecação do musculo compressor da glândula (M) e visualização da glândula principal de veneno (GP), c. Vista do ducto primário (DP) e da glândula acessória (GA), d. Dissecação completa do aparelho glandular de veneno. Fonte: Fotografado por Hortêncio (2006) ${ }^{3}$.

\subsection{Delineamento experimental}

Neste projeto utilizamos uma abordagem proteômica com intuito de identificar as proteínas cujas sínteses foram reguladas durante o ciclo de produção de veneno da glândula principal de veneno e da glândula acessória e ainda proteínas cujas sínteses foram reguladas pela inervação noradrenérgica da glândula principal de veneno. A Figura 6 ilustra de forma geral o delineamento experimental utilizado neste projeto.

\footnotetext{
${ }^{3}$ HORTÊNCIO, Thiago M. São Paulo, 2006.
} 
Figura 6 - Delineamento experimental deste projeto para identificar, na serpente Bothrops jararaca, as proteínas da glândula principal de veneno e da glândula acessória reguladas durante o ciclo de produção de veneno e ainda as proteínas da glândula principal de veneno regulada pela inervação noradrenérgica.

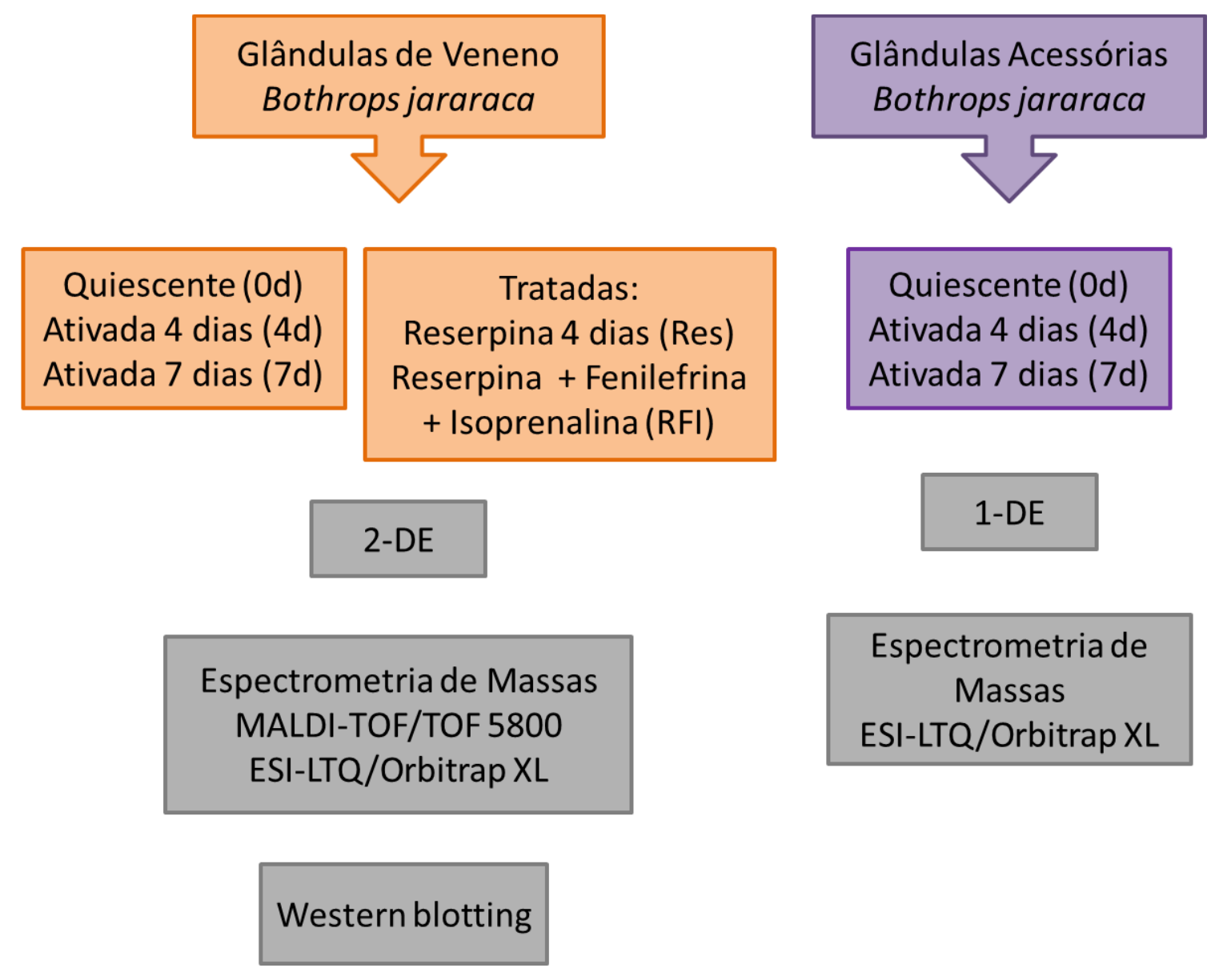

\subsection{Extrato proteico}

As glândulas de veneno e acessórias coletadas foram imediatamente congeladas em nitrogênio líquido e em seguida maceradas no homogeneizador de inox com nitrogênio líquido. As glândulas maceradas foram incubadas em tampão de lise (Tris- $\mathrm{HCl} 30 \mathrm{mM}, \mathrm{pH}$ 8,5, Uréia $7 \mathrm{M}$, Tiuréia $2 \mathrm{M}$, Chaps $4 \%$ ) durante 60 minutos e em seguida centrifugadas à $12.000 \mathrm{~g}, 4{ }^{\circ} \mathrm{C}$ por 10 minutos. O sobrenadante obtido foi removido e congelado a $-80{ }^{\circ} \mathrm{C}$ para posterior análise. 


\subsection{Quantificação de proteínas}

A concentração de proteínas dos extratos de glândulas de veneno e glândulas acessórias foi determinada pelo método de BRADFORD (1976), utilizando albumina bovina como padrão e reagente Bio-Rad assay protein (Bio-Rad, Hercules, C.A., USA). A absorbância foi lida em $620 \mathrm{~nm}$, no fotômetro Multiskan EX (Thermo Fisher Scientific, Rockford, USA).

\subsection{Análise proteômica da glândula de veneno de Bothrops jararaca}

A abordagem proteômica que nós optamos neste projeto para as glândulas de veneno foi à eletroforese bidimensional que é composta basicamente por duas etapas: a primeira dimensão, focalização isoelétrica e a segunda dimensão, eletroforese em gel de poliacrilamida na presença de dodecil sulfato de sódio (SDS). As eletroforeses bidimensionais foram realizadas em triplicatas técnicas, sendo que para cada grupo experimental foram realizadas três réplicas biológicas, ou seja, $\mathrm{N}=3$. Anteriormente à focalização isoelétrica, os extratos das glândulas de veneno $(750 \mu \mathrm{g})$ foram precipitados com acetona na proporção 1:3 (1 volume de amostra para 3 volumes de acetona) e incubados a $-20^{\circ} \mathrm{C}$ durante 3 horas. Após a incubação os extratos foram centrifugados a $14.000 \mathrm{~g}$ por 10 minutos e o sobrenadante descartado (JIANG; HE; FOUNTOULAKIS, 2004).

\subsubsection{Reidratação das fitas}

O precipitado resultante da dessalinização e concentração com acetona foi solubilizado em $340 \mu \mathrm{L}$ de solução de reidratação (Destreak, GE Healthcare, Uppsala, Sweden) contendo 0,5\% de tampão de gradiente de pH imobilizado (IPG) de pH 3-10 (GE Healthcare). Para reidratação foram utilizadas fitas de IPG de $18 \mathrm{~cm} \mathrm{e} \mathrm{pH} \mathrm{imobilizado} \mathrm{variando} \mathrm{de} 3$ a 10. As amostras foram aplicadas em aparato para reidratação e as fitas posicionadas sobre as amostras e deixadas em repouso overnight em temperatura ambiente. 


\subsubsection{Focalização isoelétrica (1 ${ }^{a}$ dimensão)}

Após a reidratação das fitas foi realizado a focalização isoelétrica a $20{ }^{\circ} \mathrm{C}$, no sistema Ettan IPGphor II (GE Healthcare). As fitas foram submetidas inicialmente a $100 \mathrm{~V}$ por 15 horas para remoção de sais e impurezas e em seguida iniciado o protocolo de focalização isoelétrica descrita pelo fabricante e especificado na Tabela 1. Ao final da focalização isoelétrica foram acumulados $25.500 \mathrm{Vh}$.

Tabela 1 - Protocolo de focalização isoelétrica utilizado para fitas de $18 \mathrm{~cm}$.

\begin{tabular}{cll}
\hline Etapa & Voltagem $(\mathbf{V})$ & Volt-hora $(\mathbf{k V h})$ \\
$\mathbf{1}^{\mathbf{a}}$ Fase & 100 & $1500 \mathrm{em} 15 \mathrm{~h}$ \\
$\mathbf{2}^{\mathbf{a}}$ Fase & 500 & 500 \\
$\mathbf{3}^{\mathbf{a}}$ Fase Gradiente & 1000 & 800 \\
$\mathbf{4}^{\mathbf{a}}$ Fase Gradiente & 10000 & 16500 \\
$\mathbf{5}^{\mathbf{a}}$ Fase & 10000 & 6200 \\
\hline
\end{tabular}

\subsubsection{Equilíbrio das fitas}

Após a focalização, as fitas foram reduzidas com solução de equilíbrio (Tris- $\mathrm{HCl} 75$ $\mathrm{mM}$ pH 8,8, uréia $6 \mathrm{M}$, SDS 2\%, glicerol 29,3\%, azul de bromofenol 0,002\%) contendo ditiotreitol (DTT) 1\%, durante 15 minutos à temperatura ambiente, e em seguida alquiladas com solução de equilíbrio contendo iodoacetamida 2,5\% durante 15 minutos à temperatura ambiente, sob agitação constante.

\subsubsection{Eletroforese em gel de SDS-poliacrilamida (2a dimensão)}

A eletroforese em gel de poliacrilamida $12,5 \%$ na presença de SDS foi realizada de acordo com o método descrito por Laemmli (1970), utilizando o sistema vertical Ettan DALTsix (GE Healthcare). As fitas foram posicionadas sobre o gel e cobertas com solução selante (agarose 0,5\% e azul de bromofenol 0,002\% em tampão de corrida [Tris base 250 mM, glicina 192 mM, SDS 1\%]) para fixação da fita e visualização da corrida. O padrão de peso molecular utilizado foi Kaleidoscope Prestained Standarts (Bio-Rad). As proteínas foram coradas com Coomassie Azul Brilhante G (CBB-G) durante 4 dias. 


\subsubsection{Análise das imagens}

As imagens dos géis foram digitalizadas utilizando o digitalizador ImageScanner III (GE Healthcare) com resolução de 300 pontos por polegada (pdi) e analisadas através do software Image Master-2D Platinum versão 7.0 (GE Healthcare). Os spots foram automaticamente detectados e manualmente editados quando necessário para remover os precipitados do corante. Somente os spots diferencialmente expressos em cada grupo, presentes em todos os géis de cada grupo experimental e que apresentavam $p<0,05$ foram considerados na análise.

\subsection{Análise proteômica da glândula acessória de Bothrops jararaca}

A abordagem proteômica que optamos para as glândulas acessórias foi a eletroforese em gel gradiente unidimensional, pelo fato destas glândulas terem um tamanho pequeno (3.3 $\pm 0.1 \mathrm{~mm}, \mathrm{~N}=4)$ e obtermos uma baixa quantidade de proteínas (150 $\mu \mathrm{g} / \mathrm{mg}$ de tecido), impossibilitando a realização dos ensaios em gel 2-DE e em triplicatas.

\subsubsection{Eletroforese em gel gradiente de SDS-poliacrilamida (1-DE)}

As proteínas dos extratos totais das glândulas acessórias (30 $\mu \mathrm{g}$ de proteína) foram desnaturadas e completamente dissociadas em tampão de amostra (SDS 4\%, glicerol 20\%, $\beta$ mercaptoetanol 10\%, tris pH 6.8, 50 mM, azul de bromofenol 0,05\%) em condições redutoras, em banho-maria fervente durante 5 minutos e foram submetidas à eletroforese em gel de poliacrilamida, gradiente de $4 \%$ a $20 \%$, na presença de SDS, segundo o método descrito por Laemmli (1970), utilizando o sistema de gel de eletroforese vertical Mini-PROTEAN Tetra cell (Bio-Rad). As proteínas foram coradas com CBB-G. A densidade de cada banda obtida na eletroforese foi quantificada através do software Quantity One (Bio-Rad). Nesta abordagem, optamos por identificar todas as bandas do perfil proteico, para isso, as colunas de cada grupo experimental foram divididas em 15 bandas. 


\subsection{Identificação das proteínas das glândulas de veneno e acessória}

\subsubsection{Digestão das proteínas em gel}

Os spots das proteínas de interesse presentes no gel bidimensional e as bandas presentes no gel em gradiente foram recortados com uma lâmina de bisturi e transferidos para um tubo de cônico, previamente lavado com metanol, água e metanol. Todos os tubos cônicos utilizados foram previamente lavados e todas as soluções utilizadas foram preparadas no momento do uso.

Para descoloração dos pedaços de géis com Coomassie Blue G, estes foram incubados com $400 \mu \mathrm{L}$ da solução descorante (acetonitrila $50 \%$ e bicarbonato de amônio $25 \mathrm{mM}$, pH 8.0) sob agitação durante 15 minutos e a solução descartada. O procedimento foi repetido duas vezes e deixado overnight para completa remoção do corante e detergente.

Os pedaços de gel foram cortados em tamanho menor e desidratados em $200 \mu \mathrm{L}$ de acetonitrila $100 \%$ durante 10 minutos. O procedimento foi repetido até que o gel ficasse opaco. Em seguida, a solução de acetonitrila foi removida o gel foi seco no sistema de centrifugação a vácuo (SpeedVac concentrator, Thermo Fisher Scientific, Bremen, Germany).

Somente para os pedaços de géis de glândulas acessórias (gel unidimensional) foram realizadas as etapas seguintes: os pedaços de géis foram incubados em $100 \mu \mathrm{L}$ de solução redutora (DTT $65 \mathrm{mM}$ em bicarbonato de amônio $100 \mathrm{mM}$ ) durante 30 minutos a $56{ }^{\circ} \mathrm{C}$. Decorrido o tempo de reidratação com a solução redutora, a solução foi removida e os pedaços de géis foram incubados em $100 \mu \mathrm{L}$ de solução alquilante (iodoacetamida $200 \mathrm{mM}$ em bicarbonato de amônio $100 \mathrm{mM}$ ) durante 30 minutos em temperatura ambiente. Em seguida, a solução alquilante foi removida e os pedaços de géis foram lavados com $200 \mu \mathrm{L}$ de bicarbonato de amônio $100 \mathrm{mM}$. A solução de bicarbonato de amônio foi removida e os pedaços de gel foram desidratados com $200 \mu \mathrm{L}$ de acetonitrila 100\%. Em seguida, a acetonitrila foi removida e as etapas de lavagem e desidratação citadas anteriormente foram repetidas e os pedaços de gel foram secos no sistema de centrifugação a vácuo (SpeedVac concentrator, Thermo Fisher Scientific).

Após esta etapa ou a descoloração dos géis, todos os pedaços de géis (glândulas de veneno e acessórias) foram reidratados em $15 \mu \mathrm{L}$ de solução de tripsina (20 ng/ $\mu \mathrm{L}$ em tampão de bicarbonato amônio $40 \mathrm{mM}, \mathrm{pH}$ 8.0) e incubados a $4{ }^{\circ} \mathrm{C}$ durante 45 minutos. $\mathrm{O}$ excesso de tripsina foi removido e $20 \mu \mathrm{L}$ de bicarbonato de amônio $40 \mathrm{mM}$, pH 8.0 foram adicionados e 
incubados overnight a $37{ }^{\circ} \mathrm{C}$. Logo em seguida, os pedaços de géis foram incubados a $56{ }^{\circ} \mathrm{C}$ durante 45 minutos.

Após a etapa de digestão, cada hidrolisado foi submetido à sonicação por 10 minutos, seguido por ciclos de vortex de 20 segundos e o sobrenadante transferido para tubos cônicos. Aos pedaços de géis foram adicionados $30 \mu \mathrm{L}$ da solução de extração (acetonitrila $50 \%$ e ácido fórmico 5\%) e incubados durante 15 minutos. O procedimento foi repetido duas vezes e todos sobrenadantes foram coletados e armazenados. No final, os extratos hidrolisados foram concentrados através de centrifugação a vácuo e armazenado a $-20{ }^{\circ} \mathrm{C}$ para posterior análise no nanoESI-LTQ/Orbitrap XL (Thermo Ficher Scientific).

\subsubsection{Análise por espectrometria de massa}

As amostras obtidas foram inicialmente resuspendidas em 1,5 $\mu \mathrm{L}$ de solução aquosa de ácido trifluoracético $0,1 \%$ em acetonitrila $60 \%$, em seguida foram sonicadas por 10 minutos e desalinizadas com Zip Tip C18 (Millipore, Darmstadt, Germany), de acordo com as instruções do fabricante. Os espectros de massas foram adquiridos nos espectrômetros de massas modelo AB Sciex MALDI-TOF/TOF 5800 ou nanoESI-LTQ/Orbitrap XL do Instituto Oswaldo Cruz - Fiocruz, no Laboratório de Toxinologia.

\subsubsection{Ionização e dessorção a laser assistida por matriz em tempo de voo/tempo de voo (MALDI-TOF/TOF)}

A fração de 0,3 $\mu \mathrm{L}$ de amostra contendo os peptídeos eluidos da coluna de Zip Tip foram misturados a solução de matriz saturada na proporção de 1:1 (10 mg/ml ácido $\alpha$-ciano4-hidroxicinamico em acetonitrila $50 \%$ e ácido trifluoracético $0,1 \%$ ) na placa de Maldi e mantido em temperatura ambiente até a secagem completa. Os dados brutos da identificação de proteínas foram obtidos no espectrômetro de massas MALDI-TOF/TOF 5800 (AB Sciex, Foster City, C.A., USA). Ambos os dados de MS e MS/MS foram adquiridos com taxas de aquisição de laser de até $400 \mathrm{~Hz}$ no modo MS e $1.000 \mathrm{~Hz}$ no modo MS/MS. Tipicamente, 2000 tiros são acumulados por espectro em ambos os modos MS e MS/MS. Até 10 sinais de íons mais intensos com uma razão de sinal/ruído superiores a 30 foram selecionados como precursores de MS/MS de aquisição, excluindo os sinais de íons comuns da matriz. Calibração externa do modo MS foi realizada utilizando uma mistura de quatro peptídeos: 
des-Arg1-bradykinin ( $\mathrm{m} / \mathrm{z}$ 904.468); angiotensin I ( $\mathrm{m} / \mathrm{z}$ 1296.685); Glu1-fibrinopeptide B ( $\mathrm{m} / \mathrm{z}$ 1570.677) e ACTH (18-39) ( $m / z$ 2465.199). O espectro MS/MS foi calibrado externamente utilizando massas de fragmento de íons observados no espectro MS/MS da angiotensina I. Seguindo a aquisição de dados, uma lista dos picos foi obtida dos dados brutos de MS/MS utilizando a ferramenta ABI Extractor (Bioinformatics Solutions Inc., Waterloo, O.N., Canada) para posteriores análises no software PEAKS 5.3.

\subsubsection{Nanocromatografia acoplada ao espectrômetro de massas de alta resolução nanoeletroespray (nanoESI-LTQ/Orbitrap XL)}

Para fração de $1 \mu \mathrm{L}$ da amostra tripsínica desalinizada, $9 \mu \mathrm{L}$ da solução de ácido fórmico $1 \%(\mathrm{v} / \mathrm{v})$ foram adicionados. A partir da solução resultante, $4 \mu \mathrm{L}$ foram inicialmente aplicados na coluna de $2 \mathrm{~cm}$ de comprimento (100 $\mu \mathrm{m}$ diâmetro interno) empacotada com a matriz 200 A Magic C18 AQ de $5 \mu \mathrm{m}$ (Michrom Bioresources, Alburn, C.A., USA) seguido pela separação em coluna de 10,5 cm de comprimento (75 $\mu \mathrm{m}$ diâmetro interno) empacotada com a mesma matriz, diretamente sobre o PicoTip $15 \mu \mathrm{m}$ (New Objective, Cambrigde, M.A., USA). A cromatografia foi realizada no equipamento EASY-nLC II (Thermo Fisher Scientific). As amostras foram aplicadas na coluna com um fluxo de $2000 \mathrm{~nL} / \mathrm{min}$ e para a separação cromatográfica foi utilizado um fluxo de $200 \mathrm{~nL} / \mathrm{min}$. A fase móvel A foi $0,1 \%$ (v/v) de ácido fórmico em água, enquanto que a fase B foi $0,1 \%(\mathrm{v} / \mathrm{v})$ de ácido fórmico em acetonitrila e as condições gradientes foram as seguintes: 2 a 40\% de B em 32 minutos; até $80 \%$ de B em 4 minutos, mantendo esta concentração por mais 2 minutos, antes do reequilíbrio da coluna. Os peptídeos eluidos foram diretamente introduzidos no espectrômetro de massas nanoLTQ/Orbitrap XL (Thermo Fisher Scientific) para análise. A fonte de tensão foi definida para $1,9 \mathrm{kV}$, temperatura capilar de $200{ }^{\circ} \mathrm{C}$ e a voltagem do tubo da lente para 100 V. Os valores alvos para o Ion trap completo e MSn AGC (Automatic Gain control) foram de 30.000 e 10.000 respectivamente, enquanto que o valor alvo do FTMS (Fourier Transform Mass Analysers) AGC foi definido para 500.000. O espectro MS1 foi adquirido no analisador Orbitrap ( $\mathrm{m} / \mathrm{z} 300$ a 1.700) com a resolução de 60.000 (para $\mathrm{m} / \mathrm{z}$ 445.1200). Para cada espectro, os 10 íons mais intensos foram submetidos à fragmentação CID (collision induced dissociation) (sinal mínimo exigido 10.000; largura de isolamento de 2,5; energia de colisão normalizada de 35,0; ativação Q de 0,25 e tempo de ativação de $30 \mathrm{~ms}$ ) seguido pela aquisição no MS2 do analisador linear. A opção de exclusão dinâmica foi ativada e habilitada com os seguintes valores definidos para cada parâmetro (repetição da contagem $=1$; duração 
da repetição $=30$ s; tamanho da lista de exclusão $=500$; duração da exclusão $=45$ s e largura da massa de exclusão $=10$ ppm).

\subsubsection{Analise dos dados pelo software PEAKS}

Todos os dados gerados para as glândulas de veneno foram analisados pelo software PEAKS versão 5.3 realizada em 19 de Agosto de 2011 (Bioinformatics Solutions Inc). Para as glândulas acessórias, os dados gerados foram analisados pelo software PEAKS versão 6 realizada em 4 de Abril de 2012. Primeiramente, os dados brutos foram submetidos ao refinamento, onde se procedeu à correção da massa do precursor e dos processos peak centroiding, charge deconvolution e deisotoping. Para as análises posteriores foram utilizados os limites de tolerância para os valores de massa dos íons precursores (em ppm) e para os íons fragmentos (em Da) para as diferentes abordagens de espectrometria de massas utilizadas: MALDI-TOF/TOF (100 ppm e 0,3 Da); nanoESI-LQT/Orbitrap XL (20 ppm e 0,6 Da). Além disso, foi considerada a digestão enzimática do tipo semi-triptica e foi aceito no máximo duas clivagens por proteína. Todos os dados foram submetidos inicialmente à busca pela ferramenta De Novo, permitindo-se modificações variáveis em cistina $(+57.02 \mathrm{Da}-$ carbamidometilação) e metionina, histidina e triptofano (+15,99 Da - oxidação), sendo aceito o máximo de duas modificações por peptídeo. Em seguida, foi realizada a busca mediante a ferramenta de pesquisa PEAKS DB, estabelecendo a massa do precursor como monoisotópica e permitindo uma modificação variável em cisteína (+57.02 Da), sendo aceitáveis no máximo duas modificações por peptídeo. Todas as buscas foram realizadas contra dois bancos de dados públicos NCBI não redundante, compostos por uma compilação de sequencias proteica descrita para Serpentes e Metazoa. A gama de detecção falsa (FDR - False Discovery Rate) foi estimada através do uso da ferramenta decoy. Finalmente, os dados de todas as buscas foram consolidados e somente os resultados no qual o FDR estimado foi menor ou igual a $1 \%$ foram aceitos como identificações confiáveis.

\subsection{Western blotting}

Para confirmação da expressão das proteínas identificadas por espectrometria de massa foi realizado ensaio de Western blotting utilizando anticorpos policlonais distintos:

1. Anti-actina, uma proteína de citoesqueleto, de procedência Sigma-Aldrich, St. Louis, M.O., USA. 
2. Anti-MSP1/2, uma proteína serinoproteinases que foi gentilmente cedida pela Dra. Solange M. T. Serrano, do Laboratório Especial de Toxinologia Aplicada do Instituto Butantan (SERRANO et al., 1993).

Após a 1-DE, as bandas proteicas foram transferidas para membrana de nitrocelulose de acordo com Towbin et al. (1979), através da utilização do sistema Mini-PROTEAN TGX (Bio-Rad). Após a transferência, as membranas foram imersas em solução 0,5\% de Vermelho de Ponceau em ácido acético $1 \%$ para verificar a correta transferência das proteínas. As membranas foram lavadas com água destilada e incubadas em solução de bloqueio (leite desnatado $5 \%$ em tampão fosfato salina $\left[\mathrm{NaH}_{2} \mathrm{PO}_{4} \cdot \mathrm{H}_{2} \mathrm{O}\right.$ 1,5 Mm, $\mathrm{Na}_{2} \mathrm{HPO}_{4} 8 \mathrm{mM}, \mathrm{NaCl} 140$ $\mathrm{mM}$, Tween 20 0,5\%]) overnight. O anticorpo primário contra actina foi utilizado na diluição 1:500 e incubado durante 2 horas em temperatura ambiente, sob agitação. $O$ anticorpo primário anti-MSP1/2 foi utilizado na diluição 1:500 e incubado overnight à $4{ }^{\circ} \mathrm{C}$. Após as incubações com os anticorpos primários, as membranas foram lavadas com tampão de lavagem (Tween-20 0,2\% e tampão fosfato salina 10\%). O anticorpo secundário (anti-IgG de coelho conjugada à peroxidase, KPL, Gaithersburg, Maryland, USA) foi utilizado na diluição 1:2.000 e incubado durante 30 minutos à temperatura ambiente, sob agitação. Em seguida, as membranas foram lavadas com tampão de lavagem. Para revelação foi utilizado o reagente de quimioluminescência SuperSignal West Pico (Thermo Fisher Scientific) e imediatamente após a incubação foi realizada a revelação através do fotodocumentador ChemiDoc XRS (Bio-Rad).

Após a eletroforese unidimensional a densidade das bandas foi quantificada através do software Quantity One (Bio-Rad).

\subsection{Análise estatística}

Os resultados apresentados estão expressos na forma de média \pm erro padrão da média e estes dados foram gerados no software Excel. A diferença estatística entre mais de duas médias foi analisada pelo teste de variância ANOVA seguido pelo teste de Mann-Whitney para avaliar as diferenças entre os grupos. O nível de significância aceito foi de $5 \%(p<0,05)$. 


\section{RESULTADOS}




\subsection{Síntese proteica em glândulas de veneno durante o ciclo de produção de veneno}

A análise dos géis realizada no software Platinum 7.0 nos permitiu uma comparação entre os diferentes estágios do ciclo de produção de veneno. Foi possível constatar uma expressiva diferença entre os perfis proteicos das glândulas de veneno das serpentes Bothrops jararaca no estágio quiescente, ativadas 4 e 7 dias após a extração de veneno por eletroforese em gel bidimensional (2-DE).

No estágio quiescente foram encontrados 93 spots exclusivos, enquanto que nos estágios ativados 4 e 7 dias após a extração de veneno foram encontrados 148 e 243 spots exclusivos, respectivamente, como demonstra o digrama de Venn (Figura 7). Quando comparado os três grupos experimentais apenas 3 spots foram encontrados em comum. A análise entres os estágios quiescente e ativado 4 dias após a extração de veneno mostrou 8 spots presentes em ambas as condições e entre o estágio quiescente e ativado 7 dias após a extração de veneno mostrou 10 spots presentes em ambas as condições. Entre os estágios ativados 4 e 7 dias após a extração de veneno foram encontrados 10 spots em comum (Figura 7).

Figura 7 - Diagrama de Venn representando a análise comparativa dos géis 2-DE de glândulas de veneno das serpentes Bothrops jararaca fêmeas durante o ciclo de produção de veneno.

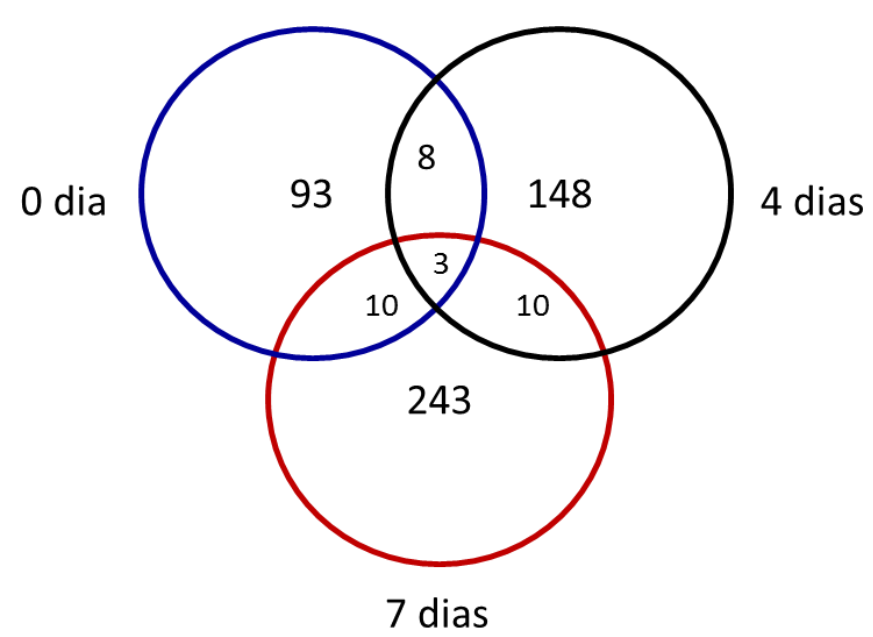

Os dados apresentados de cada grupo estudado são resultados da análise de nove géis (triplicatas biológicas ( $\mathrm{N}=3$ ) e as corridas realizadas em triplicatas técnicas). 
Por exemplo, analisando os géis visualmente, é possível perceber alguns spots específicos com alta densidade tais como um spot grande de aproximadamente $78 \mathrm{kDa}$ e ainda alguns spots menores de aproximadamente de $32 \mathrm{kDa}$ no estágio quiescente, não estão presentes nos estágios ativados do ciclo (Figura 8).

\subsubsection{Identificação das proteínas da glândula de veneno durante o ciclo de produção de veneno}

A partir da detecção dos spots exclusivos de cada condição estudada, foram selecionados e submetidos à digestão tripsínica os spots que apresentavam uma densidade maior ou igual a 0,02 (Figura 8). Primeiramente, todos os spots selecionados foram identificados por espectrometria de massas do tipo MALDI-TOF/TOF (AB Sciex 5800). No entanto, foram aceitos somente as proteínas que obtiveram o Peaks Score acima de $60 \%$ e ao menos um peptídeo sequenciado com o Peaks Score igual ou maior que 99\%. Como alguns spots identificados não foram aceitos, estes spots foram submetidos a outro espectrômetro de massas do tipo ESI-LTQ/Orbitrap XL (Thermo Fisher Scientific), onde foi possível uma

melhor identificação das proteínas. É interessante ressaltar que o espectrômetro de massas ESI-LTQ/Orbitrap XL é um equipamento mais sensível e isso possibilitou a identificação de mais de uma proteína por spot digerido.

Todas as buscas realizadas foram feitas contra o mesmo banco de dados usado pelo PEAKS v 5.3. Finalmente, os dados de todas as buscas foram consolidados e somente os resultados no qual o FDR estimado foi menor ou igual a $1 \%$ foi considerado como uma identificação confiável. As informações das proteínas identificadas foram coletadas no banco de dados UniProt (http://uniprot.org). A relação das proteínas identificadas, assim como outras informações pode ser obtida nos apêndices 1-3 deste trabalho. 
Figura 8 - Gel 2-DE de SDS-poliacrilamida representativo dos diferentes spots selecionados dos extratos de glândulas de veneno das serpentes Bothrops jararaca fêmeas durante o ciclo de produção de veneno.
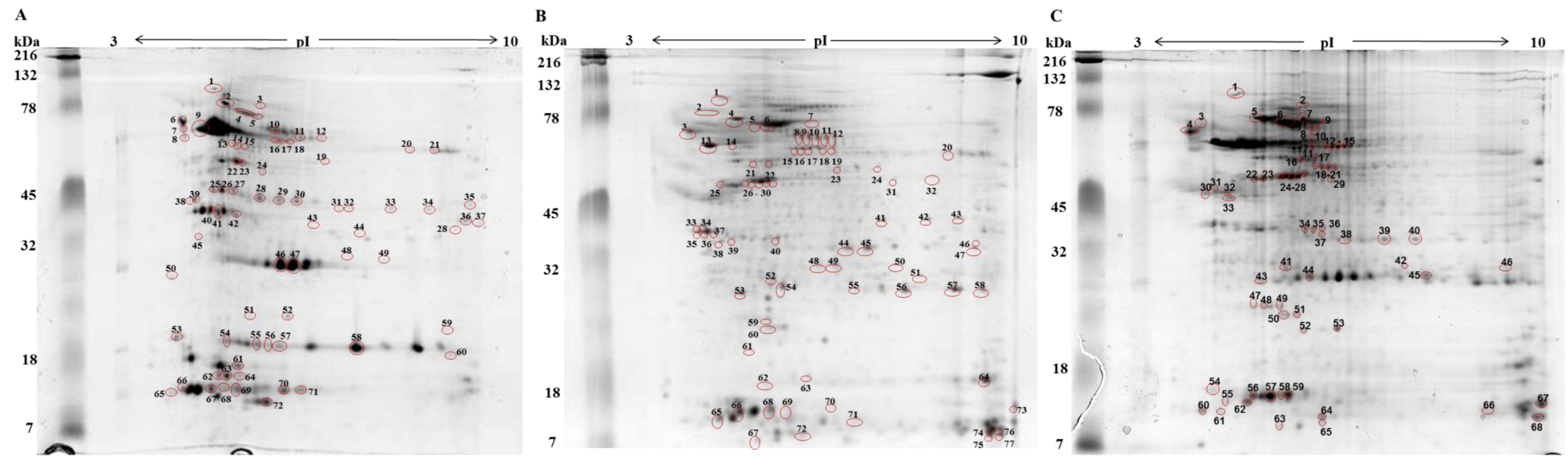

Extratos de glândula de veneno no estágio quiescente (A), estágio ativado 4 dias (B) e 7 dias (C) após a extração de veneno. Géis corados com CBB-G. Ensaios realizados em triplicata biológica $(\mathrm{N}=3)$ e as corridas realizadas em triplicatas técnicas. 
Nos géis 2-DE de extrato de glândulas de veneno no estágio quiescente foram selecionados 72 spots e todos foram identificados, no entanto, no estágio ativado 4 dias foram selecionados 94 spots nos quais 77 foram identificados e no estágio ativado 7 dias foram selecionados 72 spots e 68 destes foram identificados. Os spots identificados estão marcados na Figura 8. Com base nestas identificações, as proteínas encontradas foram agrupadas de acordo com a sua localização subcelular.

Durante o ciclo de produção de veneno, proteínas de diversos compartimentos celulares foram identificadas, tais como: do citoplasma, da mitocôndria, do retículo endoplasmático, da membrana celular e ainda proteínas de secreção. Comparando as porcentagens de proteínas de cada compartimento subcelular em relação ao total identificado em cada estágio do ciclo de produção de veneno, podemos notar que houve um aumento na identificação de proteínas do citoplasma 4 e 7 dias após a extração de veneno e da membrana celular 4 dias após a extração de veneno, no entanto, ocorreu uma redução na identificação das proteínas mitocondriais nos estágios ativados da glândula de veneno, como demonstrado na Figura 9A, B, C. Para nossa surpresa a porcentagem de proteínas secretadas também diminuiu nos estágios ativados da glândula de veneno (Figura 9A, B, C).

Analisando cada compartimento subcelular separadamente, podemos notar diferenças na síntese de algumas proteínas do citoplasma e do retículo endoplasmático. Dentre as proteínas do citoplasma, verificamos que o número de espécies de proteínas exclusivas identificadas como actina, vimentina e tropomiosina (proteínas do citoesqueleto) e da subunidade alfa do proteassomo, tioredoxina e da proteína 40S ribossomal aumentou após a extração de veneno (Figura 10 e 11).

Em relação às proteínas do retículo endoplasmático, verificamos um aumento no número de espécies de proteínas exclusivas identificadas como Proteína disulfide isomerase (PDI) 4 dias após a extração de veneno e da Proteína 78 kDa regulada por Glucose (GRP78) 7 dias após a extração de veneno quando comparadas com o estágio quiescente como demonstra a Figura 12. 
Figura 9 - Distribuição subcelular das proteínas identificadas em glândulas de veneno das serpentes Bothrops jararaca.
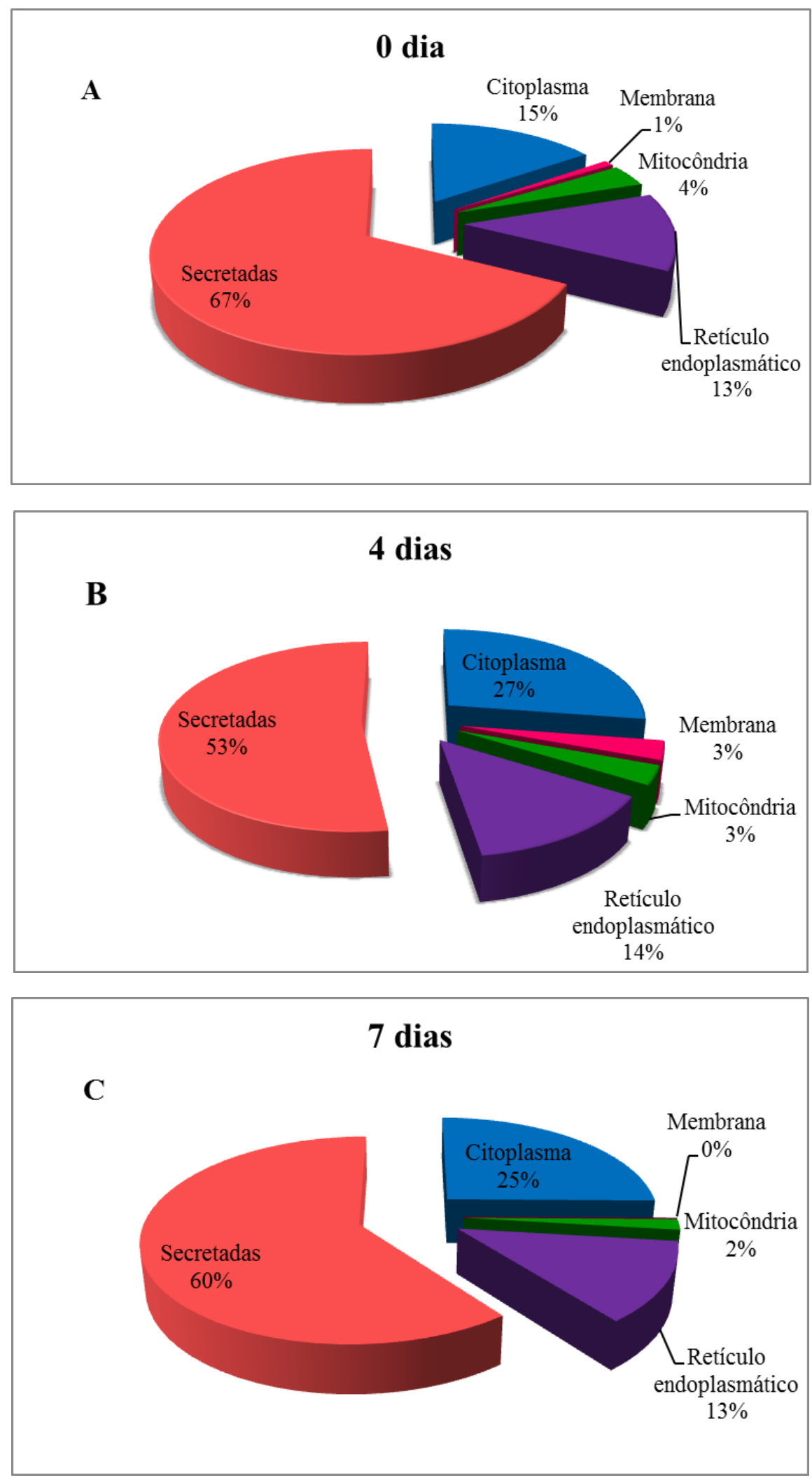

Glândulas de veneno no estágio quiescente (A), ativado 4 dias (B) e ativado 7 dias (C) após a extração de veneno. A classificação das proteínas foi obtida no banco de dados UniProt. 
Figura 10 - Aumento do número de espécies de proteínas exclusivas identificadas como citoplasmáticas, do citoesqueleto, na glândula de veneno da serpente Bothrops jararaca durante o ciclo de produção de veneno.

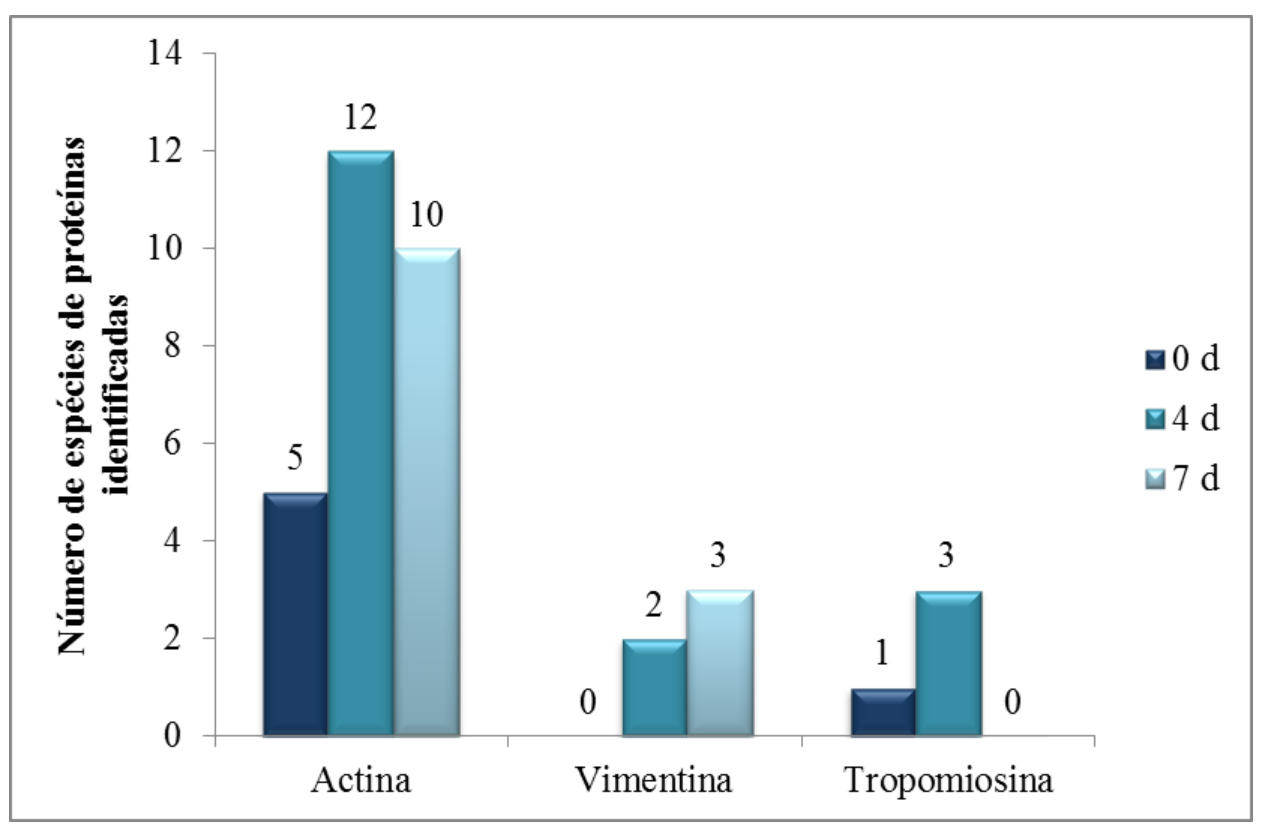

Glândula de veneno no estágio quiescente $(0$ d), estágio ativado 4 dias $(4$ d) e 7 dias (7 d) após a extração de veneno. Os números acima das colunas indicam o número de espécies de proteínas identificadas.

Figura 11 - Aumento do número de espécies de proteínas exclusivas identificadas como citoplasmáticas na glândula de veneno da serpente Bothrops jararaca durante o ciclo de produção de veneno.

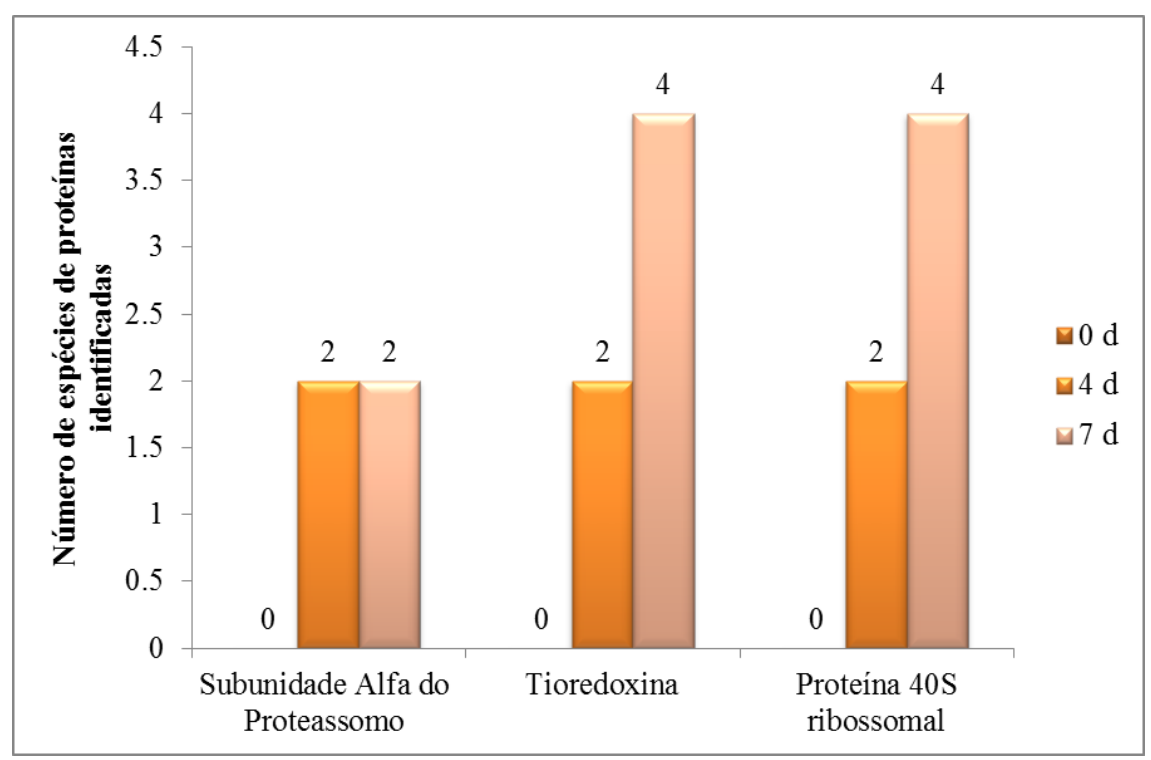

Glândula de veneno no estágio quiescente $(0$ d), estágio ativado 4 dias $(4$ d) e 7 dias $(7$ d) após a extração de veneno. Os números acima das colunas indicam o número de espécies de proteínas identificadas. 
Figura 12 - Aumento do número de espécies de proteínas exclusivas identificadas como do retículo endoplasmático na glândula de veneno da serpente Bothrops jararaca durante o ciclo de produção de veneno.

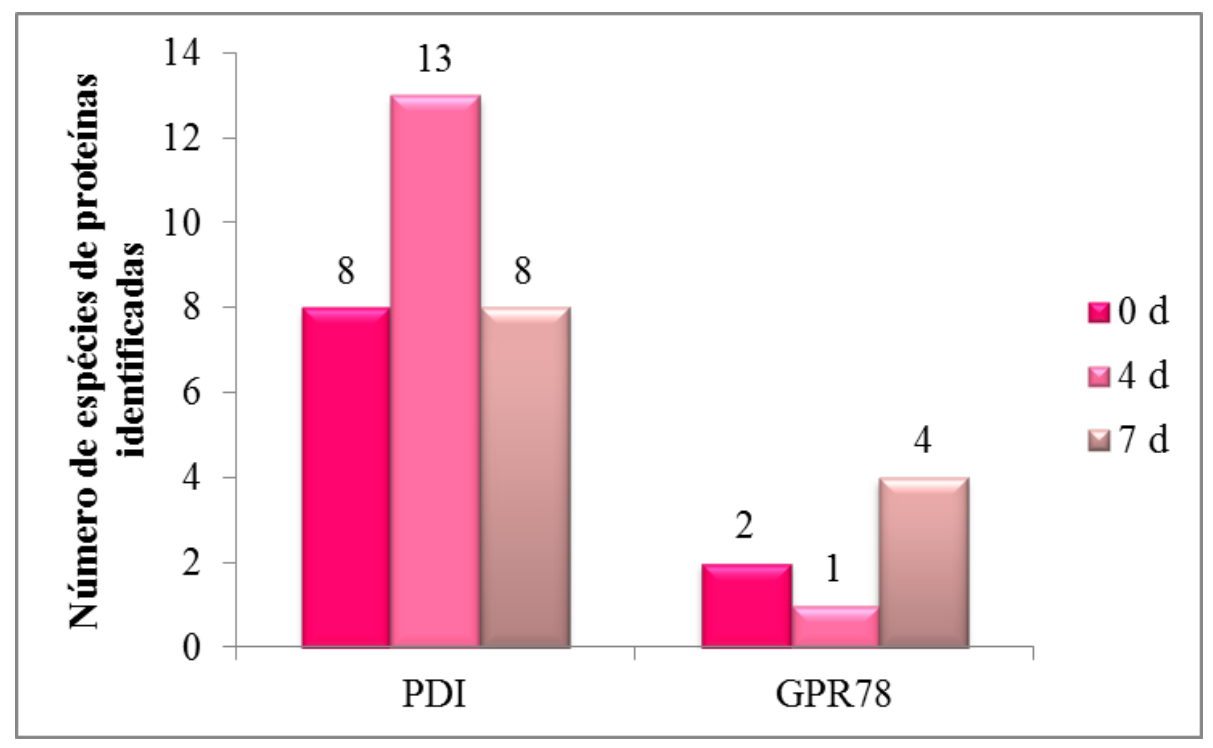

Glândula de veneno no estágio quiescente $(0$ d), estágio ativado 4 dias $(4$ d) e 7 dias $(7$ d) após a extração de veneno. Proteína dissulfeto isomerase (PDI), Proteína $78 \mathrm{kDa}$ regulada por glucose (GRP78). Os números acima das colunas indicam o número de espécies de proteínas identificadas.

Em relação às proteínas secretadas, mais especificamente às toxinas do veneno, notamos que a síntese ocorre de maneira não sincronizada. Mostramos pela primeira vez que a maioria das toxinas do veneno já está presente no estágio quiescente da glândula de veneno, tais como as lectinas tipo $\mathrm{C}$, serinoproteinases de veneno de serpente (SVSP), proteínas secretadas ricas em cisteínas (CRISP), metaloproteinases de veneno de serpentes (SVMP), fosfolipases $\mathrm{A}_{2}\left(\mathrm{PLA}_{2}\right)$, L-aminoácido oxidases (LAAO) e disintegrinas (Figura 13). É importante salientar que todas as precauções foram tomadas para completa remoção do veneno, antes da dissecção das glândulas. Uma vez que analisamos somente os spots exclusivos de cada estágio, as toxinas identificadas no estágio quiescente não podem ser devidas à presença de toxinas residuais no lumen da glândula. Além disso, se houvesse a presença de algum veneno no interior do lumen, estas toxinas também seriam detectadas em outros estágios do ciclo e não seriam identificadas como exclusivas de cada estágio.

O número total de espécies de proteínas identificadas como lectinas tipo C-símile (CTLs-símile) e SVSP foi maior no estágio quiescente, diminuindo nos estágios ativados da glândula de veneno, ao passo que o número de espécies de proteínas identificadas como SVMP, PLA 2 , LAAO, inibidores de fosfolipases $\mathrm{A}_{2}$ (PLI), fator anti-hemorrágico Bj46a, inibidor de metaloproteinase (Bj46a) e disintegrina aumentou nos estágios ativados da 
glândula de veneno. No entanto, não encontramos diferenças na síntese das proteínas CRISPs entre os estágios quiescente e ativado da glândula de veneno (Figura 13).

Figura 13 - Número de espécies de toxinas identificadas como proteínas secretadas na glândula de veneno da serpente Bothrops jararaca durante o ciclo de produção de veneno.

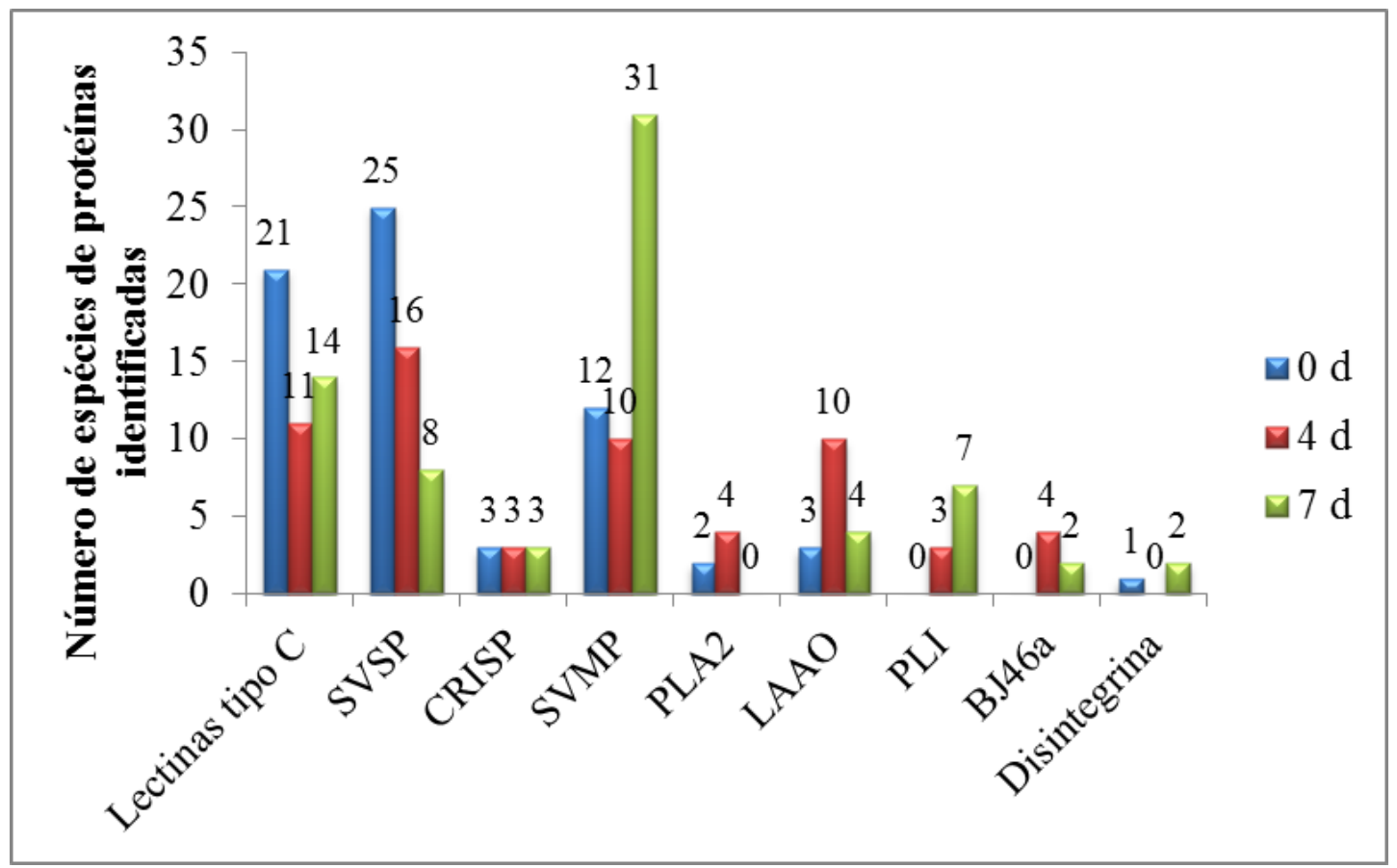

Glândula de veneno no estágio quiescente $(0$ d), estágio ativado 4 dias $(4$ d) e 7 dias $(7$ d) após a extração de veneno. Diferentes classes de toxinas foram identificadas: Lectinas tipo C, Serinoproteinases (SVSP), Proteínas secretadas ricas em cisteína (CRISP), Metaloproteinases (SVMP), Fosfolipases $\mathrm{A}_{2}\left(\mathrm{PLA}_{2}\right.$ ), L-aminoácido oxidase (LAAO), Inibidores de fosfolipases $\mathrm{A}_{2}$ (PLI), Fator Anti-hemorrágico Bj46a (Bj46a). Os números acima das colunas indicam o número de espécies de proteínas identificadas. 
$\mathrm{Na}$ família das lectinas tipo C, identificamos as lectinas tipo C verdadeiras (CTLs) e as lectinas tipo C-símile (CTL-símile), nas quais foram identificadas a lectina galactose específica, bothroinsularina, proteína ligadora da glicoproteína-Ib (GPIb-BP) e o fator de coagulação IX/X. Interessantemente, as GPIb-BP e o fator de coagulação IX/X foram identificados exclusivamente no estágio quiescente, ao passo que a lectina galactose específica foi identificada apenas nos estágios ativados da glândula de veneno. As CTLs estão presentes no estágio quiescente, no entanto, sua síntese é aumentada nos estágios ativados da glândula de veneno (4 e 7 dias). As bothroinsularinas estão presentes no estado quiescente e o número de espécies de proteínas específicas identificadas como bothroinsularinas diminuiu no $4^{\mathrm{o}}$ dia após a extração de veneno, retornando aos níveis mais elevados (33\% acima do detectado no estado quiescente) no $7^{\circ}$ após a extração de veneno (Figura 14A).

Em relação à família das SVSP identificadas, estas são na sua maioria de caráter ácido (Figura 14B). As metaloproteinases estão entre as enzimas proteolíticas mais abundantes no veneno dos viperídeos e são divididas em três classes: SVMP-PI, SVMP-PII e SVMP-PIII de acordo com seus domínios funcionais (FOX; SERRANO, 2008). As diferentes classes de metaloproteinases foram detectadas e apesar de todas estarem presentes no estado quiescente, um maior número de espécies de proteínas exclusivas identificadas como SVMP-PI e SVMPPII foi detectado no sétimo dia de ativação da glândula de veneno, sendo que, SVMP-PII foi identificada preferencialmente no sétimo dia de ativação (Figura 14C). Surpreendentemente, o número de espécies de proteínas específicas identificadas como SVMP-PIII diminuiu no $4^{\circ}$ dia após a extração de veneno, retornando aos níveis mais elevados (25\% acima do detectado no estado quiescente) no $7^{\circ}$ dia de ativação da glândula de veneno (Figura 14C).

Estes dados demonstram novamente que a produção e secreção das toxinas ocorrem de maneira independente uma da outra, ou seja, o acúmulo das toxinas não ocorre de forma paralela. 
Figura 14 - Número de espécies de proteínas identificadas das classes de toxinas na glândula de veneno da serpente Bothrops jararaca durante o ciclo de produção de veneno.
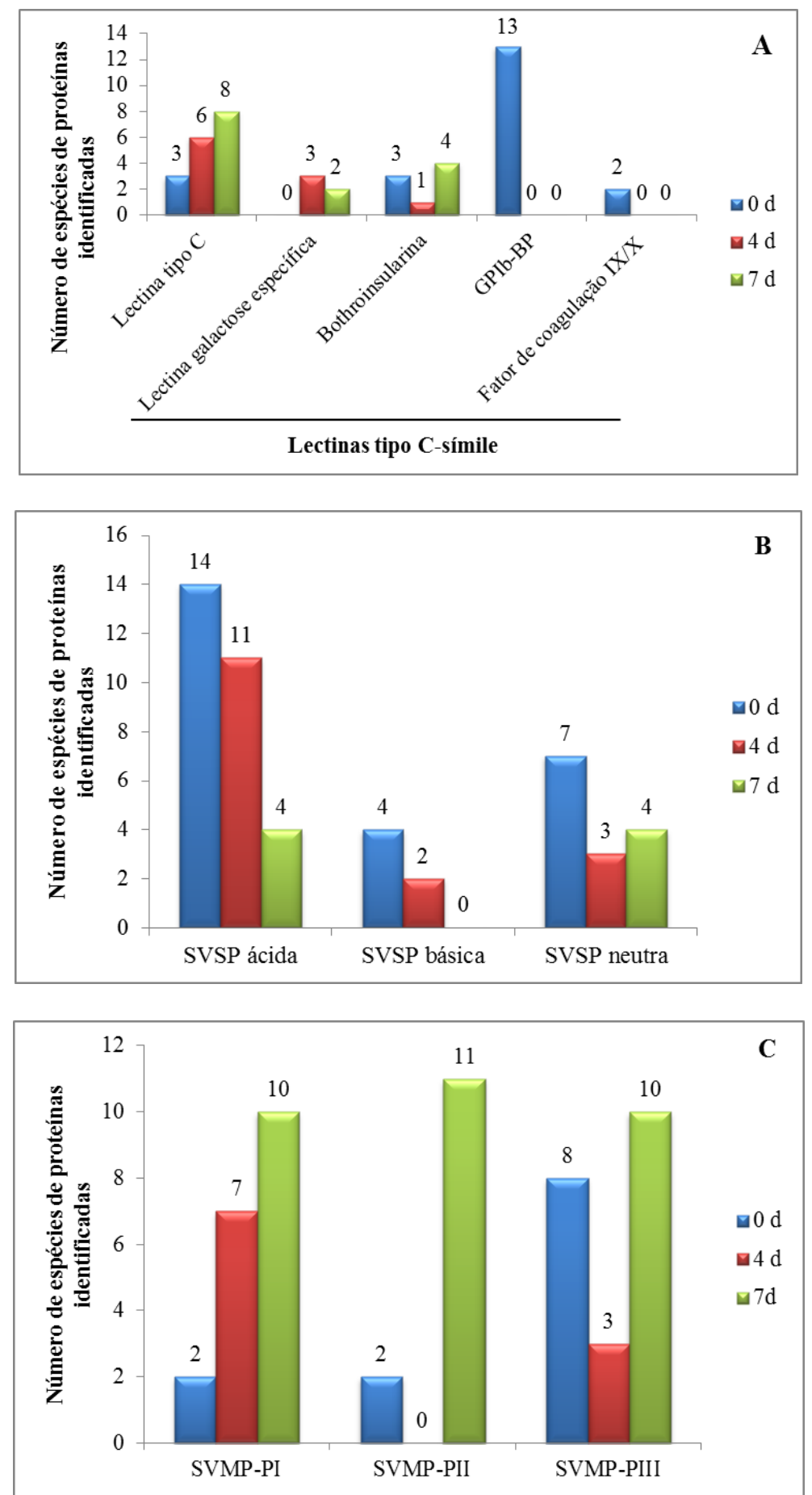

Glândula de veneno no estágio quiescente (0 d), estágio ativado 4 dias (4 d) e 7 dias (7 d) após a extração de veneno. (A) Toxinas da família das lectinas. (B) Classificação das serinoproteinases do veneno de serpentes (SVSP) de acordo com ponto isoelétrico (pI). (C) Toxinas da família das metaloproteinases do veneno de serpentes (SVMP). Proteína ligante da glicoproteína-Ib (GPIb-BP). Os números acima das colunas indicam o número de espécies de proteínas identificadas. 


\subsection{Confirmação das proteínas identificadas cujas sínteses foram reguladas durante o ciclo de produção de veneno}

Após a identificação de proteínas de diferentes compartimentos subcelulares nas quais a síntese foi regulada durante o ciclo de produção de veneno, duas proteínas (actina e SVSPs) foram selecionadas para confirmar os dados obtidos pela espectrometria de massas, utilizando a metodologia de Western Blotting.

Verificamos que a densidade da banda correspondente à actina aumentou significativamente nos estágios ativados da glândula de veneno (Figura 15A, B). A densidade mensurada de actina no estágio quiescente foi de 4.574,3 \pm 1.116,8 enquanto que no estágio ativado 4 dias e 7 dias a densidade foi de 10.280,7 $\pm 1.964,9$ e $11.441,3 \pm 903,7$ respectivamente $(p<0,05, \mathrm{n}=3)$.

A densidade das bandas correspondentes às SVSPs foi significativamente reduzida no estágio ativado da glândula de veneno $(p<0,05, \mathrm{n}=3)$. A densidade da banda no estágio quiescente foi de $1.782,7 \pm 240,7$ enquanto que no estágio ativado 4 dias e 7 dias a densidade foi de 591,7 \pm 333,5 e 518,7 $\pm 148,2$ respectivamente (Figura 16A, B).

Os resultados obtidos no Western blotting foram consistentes com os dados encontrados na espectrometria de massas. Embora os anticorpos utilizados reconheçam todas as espécies de proteínas escolhidas para esse ensaio e não somente as espécies das proteínas específicas de cada estágio, os spots em comum aos três grupos estudados foram poucos, não interferindo na mensuração dos dados. 
Figura 15 - Detecção de actina nos diferentes estágios do ciclo de produção de veneno.

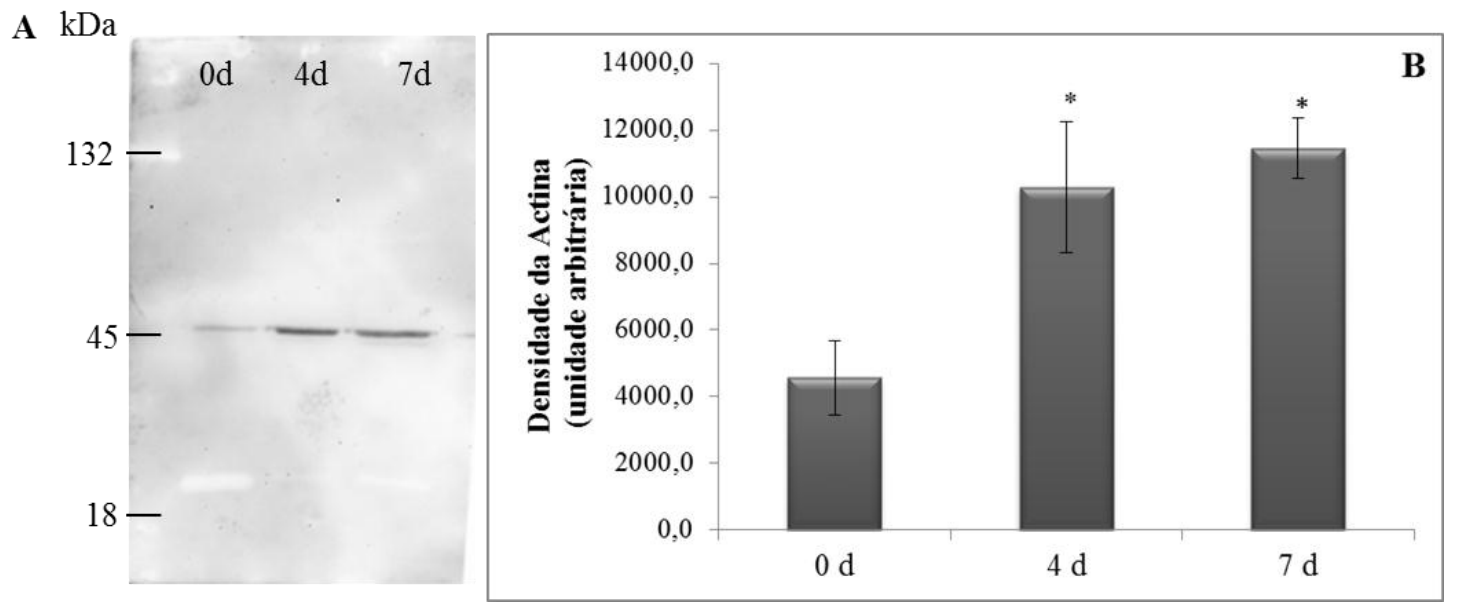

Extrato de glândula de veneno da serpente Bothrops jararaca no estágio quiescente (0d), estágio ativado 4 dias (4d) e 7 dias (7d) após a extração de veneno. Ensaios de western blotting (A). (B) Densitometria das bandas correspondentes à actina. Os valores estão expressos como média \pm erro padrão da média $(\mathrm{N}=3)$. $\mathrm{O}$ asterisco $(*)$ indica diferença estatística significativa em relação ao estágio quiescente (ANOVA, $p<0,05$ ).

Figura 16 - Detecção da SVSP (MSP1/2) nos diferentes estágios do ciclo de produção de veneno.

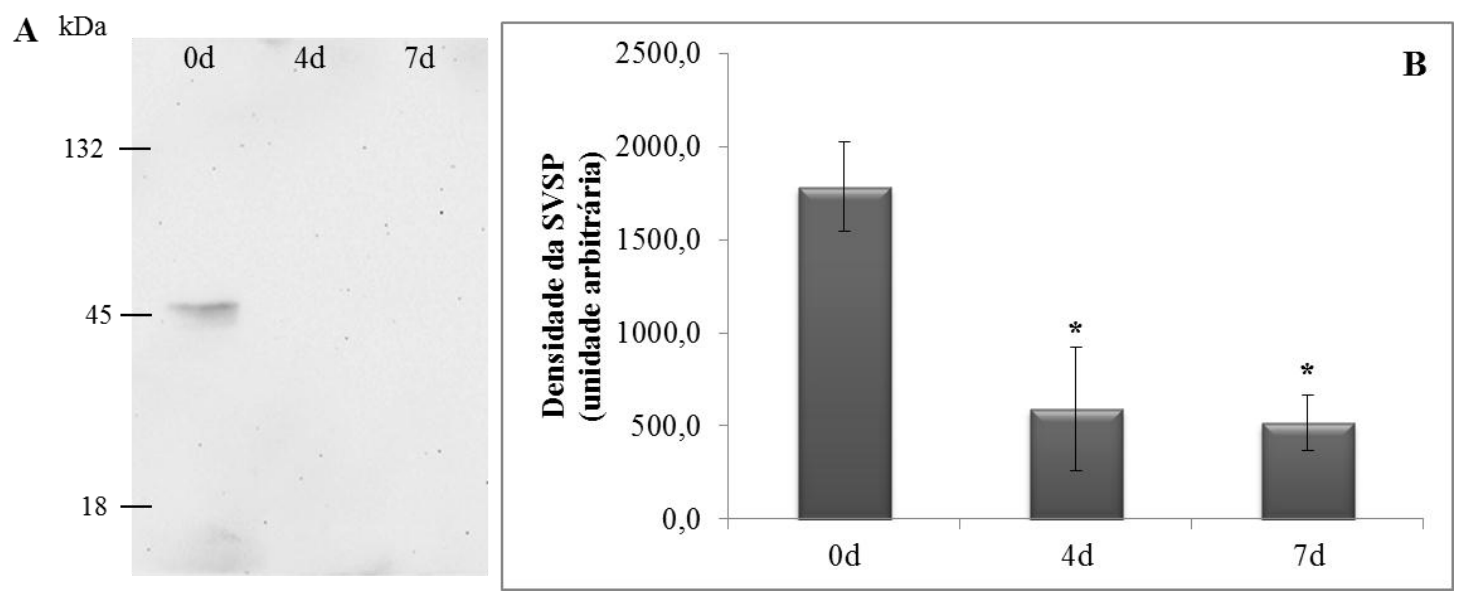

Extrato de glândula de veneno da serpente Bothrops jararaca no estágio quiescente (0d), estágio ativado 4 dias (4d) e 7 dias (7d) após a extração de veneno. (A) Ensaios de western blotting. (B) Densitometria das bandas correspondentes à SVSP. Os valores estão expressos como média \pm erro padrão da média $(\mathrm{N}=3)$. $\mathrm{O}$ asterisco $(*)$ indica diferença estatística significativa em relação ao estágio quiescente (ANOVA, $p<0,05)$. 


\subsection{Síntese proteica em glândulas de veneno reguladas pela inervação noradrenérgica}

Mostramos anteriormente que a estimulação da inervação simpática por extração de veneno leva à ativação de adrenoceptores alfa e beta que por sua vez desencadeiam uma complexa sinalização intracelular, culminando com a ativação de fatores de transcrição (KERCHOVE et al., 2008; LUNA et al., 2009; YAMANOUYE et al., 2000). Para avaliar a participação da inervação noradrenérgica na expressão gênica e consequente síntese de proteínas da glândula de veneno, bem como do veneno, tratamos um grupo de animais com reserpina durante 4 dias para depletar os estoques de noradrenalina e tratamos outro grupo de animais com reserpina e agonistas de adrenoceptores $\alpha$ e $\beta$ para verificar se o efeito causado pela reserpina é revertido, como já demonstrado anteriormente por nosso grupo (KERCHOVE et al., 2004; KERCHOVE et al., 2008; LUNA et al., 2009; YAMANOUYE et al., 1997). Portanto, para as análises a seguir, utilizamos as glândulas de veneno de serpentes ativadas 4 dias pela extração de veneno como nosso controle experimental.

Avaliando os perfis eletroforéticos dos extratos de glândulas de veneno ativadas 4 dias após a extração de veneno e os extratos de glândulas de veneno tratadas com reserpina por 4 dias (Res 4d) e tratadas com reserpina por 4 dias e ainda uma única dose de fenilefrina e isoprenalina $(\mathrm{RFI})$, podemos visualizar uma expressiva diferença entre os perfis proteicos.

A análise comparativa dos géis no software Platinum 7.0 mostrou que no estágio ativado 4 dias existem 331 spots exclusivos, no tratamento com reserpina foram encontrados 87 spots e no tratamento com RFI foram encontrados 162 spots exclusivos (Figura 17). A análise comparativa entre o estágio ativado 4 dias e o tratamento com reserpina mostrou 16 spots presentes em ambas condições, entre o estágio ativado 4 dias e o tratamento RFI foram encontrados 71 spots em comum e entre os tratamentos reserpina 4 dias e RFI foram encontrados 22 spots em comum. Foram encontrados 10 spots em comum aos três grupos experimentais avaliados (Figura 17). 
Figura 17 - Diagrama de Venn representando a análise comparativa dos géis 2-DE de glândulas de veneno das serpentes Bothrops jararaca fêmeas no estágio ativado 4 dias e a influência da inervação noradrenérgica.

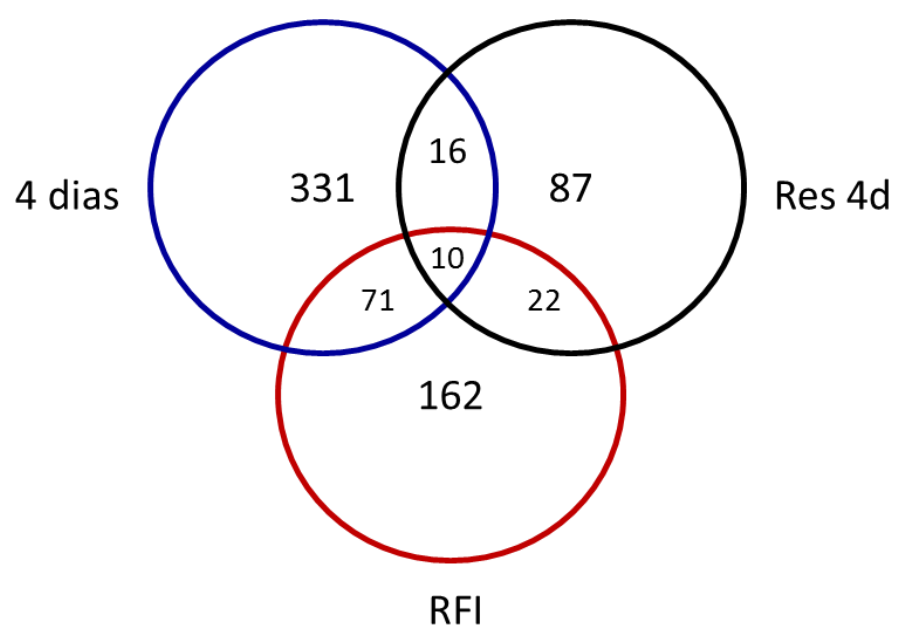

Glândulas de veneno no estágio ativado 4 dias após a extração de veneno (4 dias), serpentes tratadas com reserpina durante 4 dias (Res $4 \mathrm{~d}$ ), serpentes tratadas com reserpina durante 4 dias e receberam uma única dose de fenilefrina e isoprenalina (RFI). Os dados apresentados de cada grupo estudado são resultados da análise de nove géis (triplicatas biológicas [N=3] e as corridas realizadas em triplicatas técnicas).

Visualmente, podemos notar que o tratamento com reserpina, promoveu um aumento expressivo da quantidade de spots de aproximadamente $18 \mathrm{kDa}$ e o tratamento com os agonistas de adrenoceptores alfa e beta reduziu a quantidade destes spots como na glândula no quarto dia de ativação (Figura 18). A quantidade desses spots de aproximadamente $18 \mathrm{kDa}$ encontrados nas glândulas de veneno do grupo tratado com reserpina é muito semelhante ao do grupo de glândulas no estágio de quiescência (Figura 8A e 18B). 
Figura 18 - Gel 2-DE de SDS-poliacrilamida representativo dos diferentes spots selecionados após tratamento com reserpina e agonistas de adrenoceptores alfa e beta em glândulas de veneno das serpentes Bothrops jararaca fêmeas.
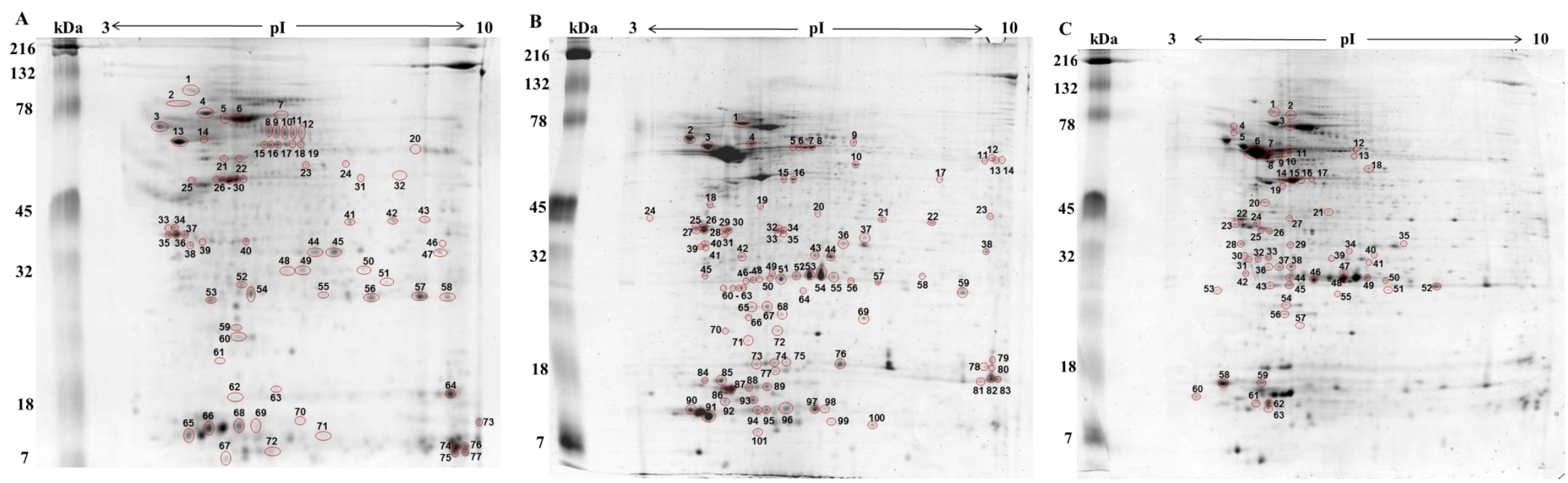

Glândulas de veneno no estágio ativado 4 dias após a extração de veneno (A), tratadas com reserpina durante 4 dias (B) e tratadas com reserpina mais fenilefrina e isoprenalina (C). Géis corados com CBB-G. Ensaios realizados em triplicatas biológicas $(\mathrm{N}=3)$ e as corridas realizadas em triplicatas técnicas. 


\subsubsection{Identificação das proteínas da glândula de veneno dos quais as sínteses são reguladas pela inervação noradrenérgica}

Após a análise comparativa entre os grupos experimentais, passamos para etapa de identificação dos spots exclusivos de cada condição estudada. Foram selecionados e submetidos à digestão tripsínica os spots que apresentavam uma densidade maior ou igual a 0,02 .

Os mesmos critérios utilizados para identificação dos spots descrito no item 4.1.1 foram utilizados. As informações das proteínas identificadas foram coletadas no banco de dados UniProt (http://uniprot.org). A relação das proteínas identificadas, assim como outras informações, pode ser obtida nas tabelas 4 e 5 no apêndice deste trabalho.

Selecionamos para identificação 109 spots do gel 2-DE do extrato de glândulas de veneno de serpentes tratadas com reserpina e desses 101 spots foram identificados, já do extrato de glândulas das serpentes tratadas com reserpina, fenilefrina e isoprenalina foram selecionados 63 spots e todos foram identificados. As proteínas identificadas foram agrupadas de acordo com a localização subcelular obtida no banco de dados UniProt.

Comparando as porcentagens de proteínas de cada compartimento subcelular em relação ao total identificado em cada grupo, verificamos que houve um aumento na porcentagem das proteínas do citoplasma e mitocôndria e redução na porcentagem das proteínas da membrana celular e do retículo endoplasmático no grupo tratado com reserpina, no entanto, o tratamento com agonistas de adrenoceptores não reverteu o efeito de reserpina (Figura 19), não evidenciando, dessa forma, a participação da inervação noradrenérgica. 
Figura 19 - Distribuição subcelular das proteínas identificadas nas glândulas de veneno da serpente Bothrops jararaca fêmea após tratamento com reserpina e agonistas de adrenoceptores alfa e beta.
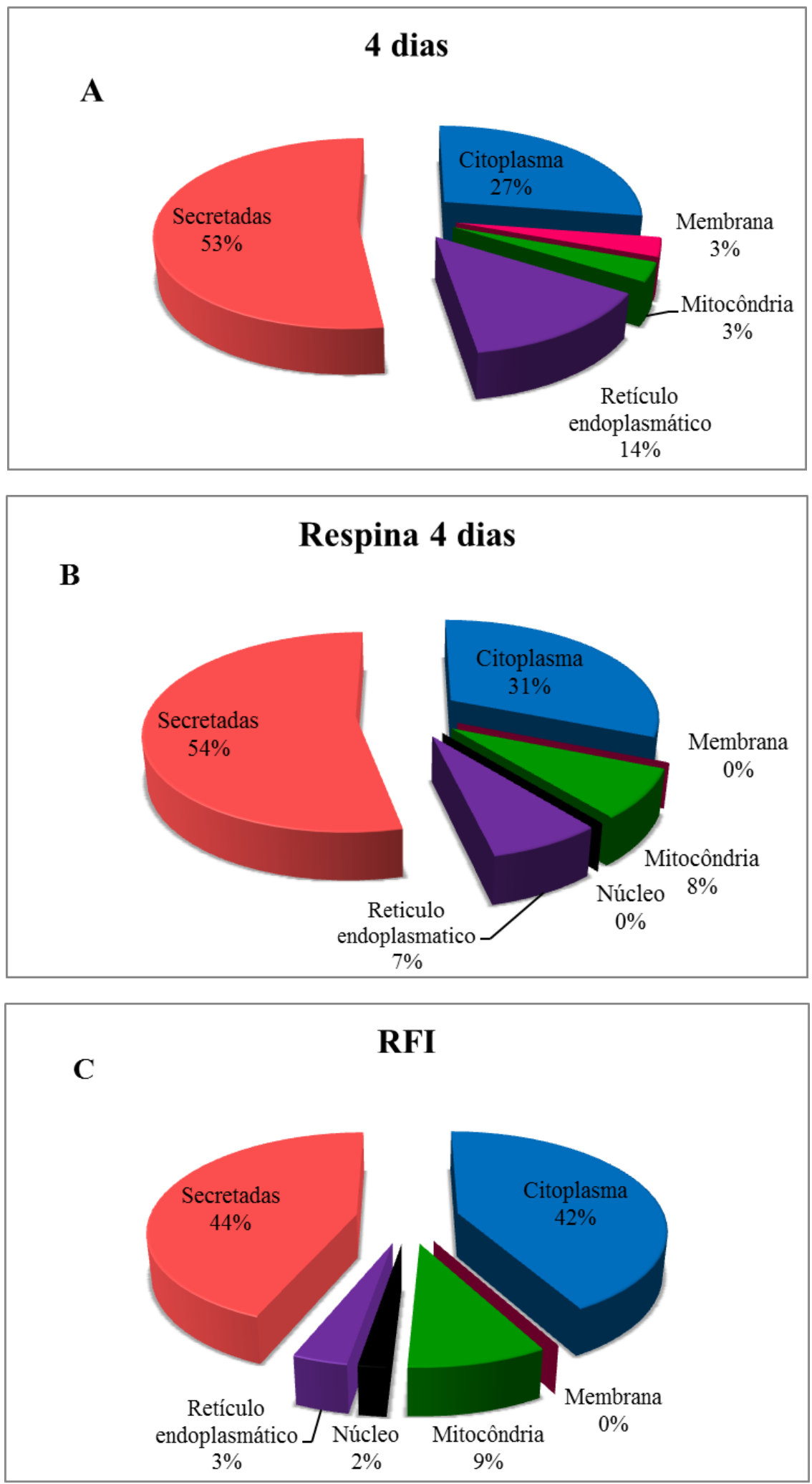

Glândulas de veneno no estágio ativado 4 dias após a extração de veneno (A), tratadas com reserpina (B), tratadas com reserpina, fenilefrina e isoprenalina (RFI) (C). A classificação das proteínas foi obtida no banco de dados UniProt. 
Porém, analisando os compartimentos subcelulares separadamente, notamos que após o tratamento com reserpina houve uma diminuição do número de espécies de proteínas identificadas como vimentina, uma proteína do citoesqueleto e a administração de agonistas de adrenoceptores alfa e beta reverteu o efeito da reserpina (Figura 20). Portanto, a estimulação da inervação noradrenérgica pela extração do veneno, provavelmente está regulando positivamente a síntese de vimentina.

Outras proteínas citoplasmáticas que parecem ter sua síntese regulada pela ativação da inervação noradrenérgica são a subunidade alfa do proteassomo, a anexina A5 e a cadeia leve da miosina. Após o tratamento com reserpina o número espécies de proteínas identificadas como subunidade alfa do proteassomo reduziu e como anexina A5 e da cadeia leve da miosina aumentou. O subsequente tratamento com agonistas de adrenoceptores alfa e beta reverteu esse efeito, sugerindo que a estimulação da inervação noradrenérgica regula a síntese dessas proteínas (Figura 20).

Figura 20 - Regulação da síntese das proteínas citoplasmáticas pela inervação noradrenérgica, identificadas na glândula de veneno da serpente Bothrops jararaca.

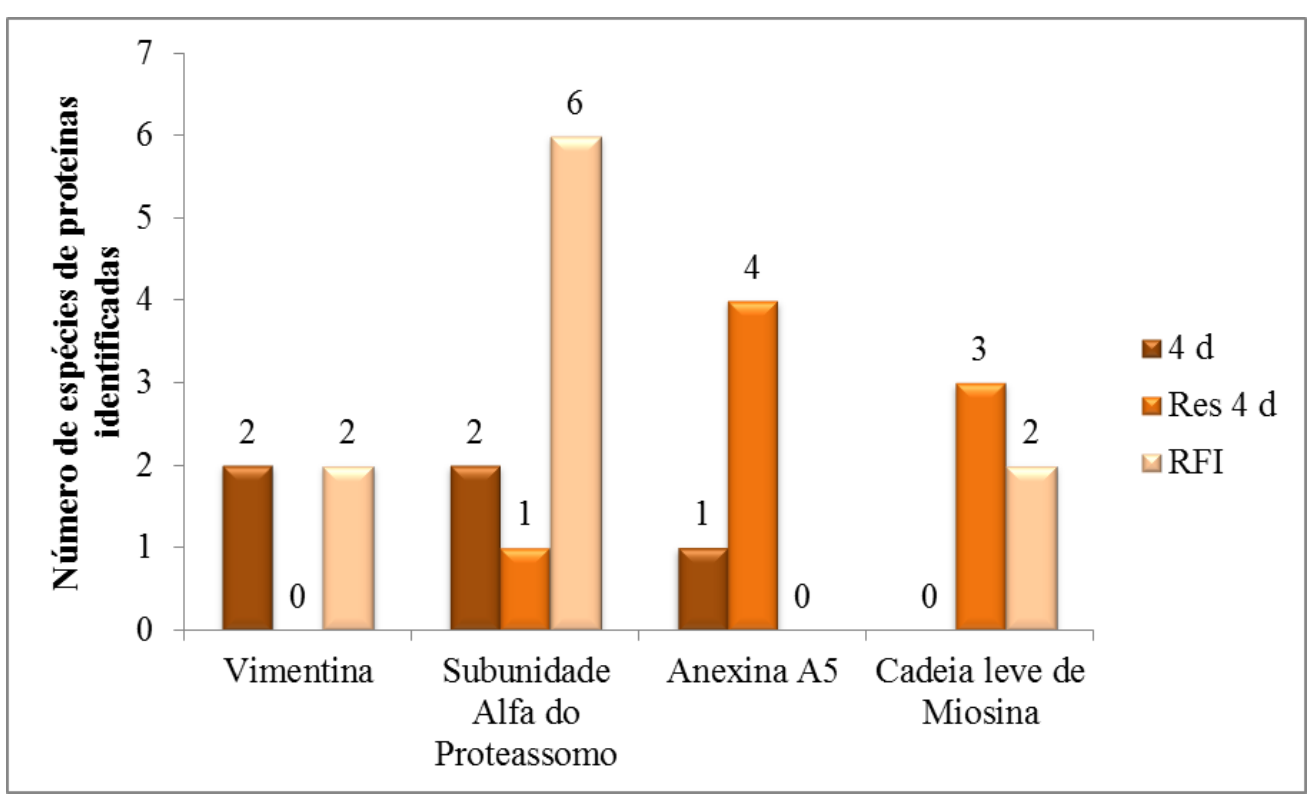

Glândula de veneno ativada 4 dias após a extração de veneno $(4 \mathrm{~d})$, tratada com reserpina por 4 dias (Res $4 \mathrm{~d}$ ), tratada com reserpina, fenilefrina e isoprenalina (RFI). A síntese das proteínas vimentina (proteína do citoesqueleto) e da subunidade alfa do proteassomo foi regulada positivamente e das proteínas anexina A5 e da cadeia leve de miosina foi regulada negativamente. Os números acima das colunas indicam o número de espécies de proteínas identificadas. 
A síntese da proteína mitocondrial, ATP sintase mitocondrial-símile parece ser regulada negativamente, visto que o tratamento com reserpina promoveu um aumento do número de espécies de proteínas identificadas e a administração de agonistas de adrenoceptores alfa e beta reverteu parcialmente o efeito da reserpina (Figura 21).

Figura 21 - Síntese de ATP sintase mitocondrial-símile é regulada pela inervação noradrenérgica na glândula de veneno da serpente Bothrops jararaca.

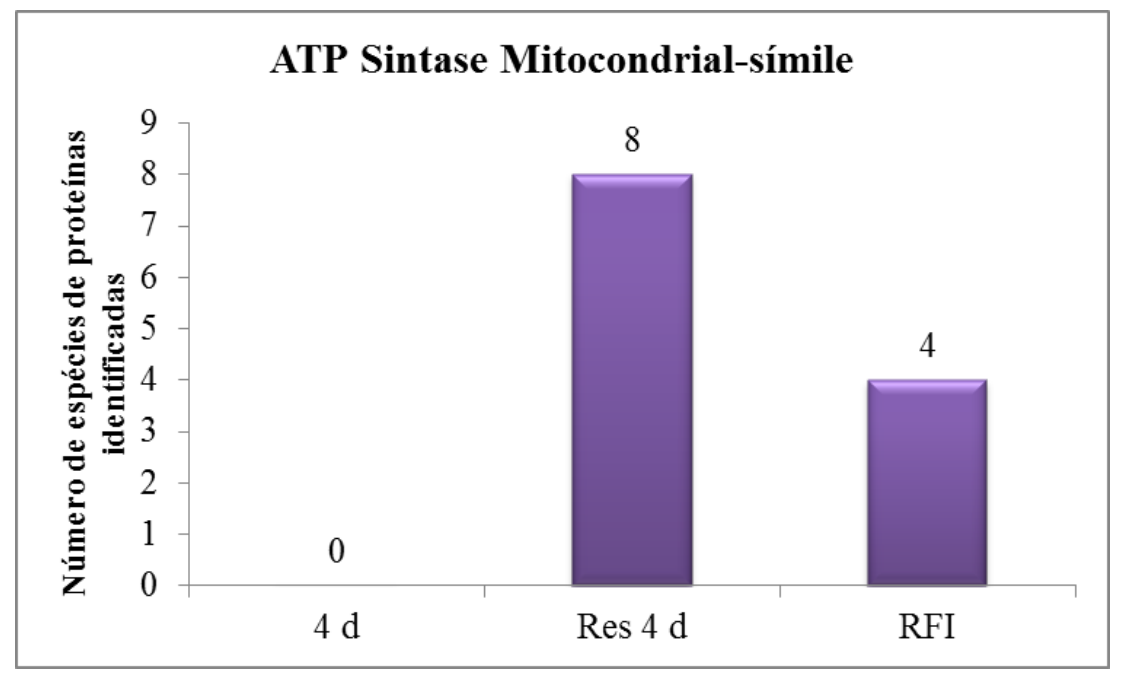

Glândula de veneno no estágio ativado 4 dias após a extração de veneno (4 d), tratada com reserpina por 4 dias (Res 4 d) e tratada com reserpina, fenilefrina e isoprenalina (RFI). Os números acima das colunas indicam o número de espécies de proteínas identificadas

A participação da inervação noradrenérgica também foi analisada na regulação da síntese de toxinas da glândula de veneno. Analisando as classes de toxinas individualmente, verificamos que o tratamento com reserpina promoveu aumento no número de espécies de proteínas identificadas como lectinas do tipo $\mathrm{C}$ e das $\mathrm{PLA}_{2}$ e após o tratamento com os agonistas este número foi reduzido novamente, sugerindo a participação da inervação noradrenérgica. Por outro lado, o número espécies de proteínas identificadas como fator antihemorrágico Bj46a foi menor em glândulas de serpentes tratadas com reserpina e quando a serpente reserpinizada foi tratada com os agonistas de adrenoceptores houve uma reversão parcial desse efeito (Figura 22). 
Figura 22 - Número de espécies de toxinas identificadas como proteínas secretadas na glândula de veneno da serpente Bothrops jararaca.

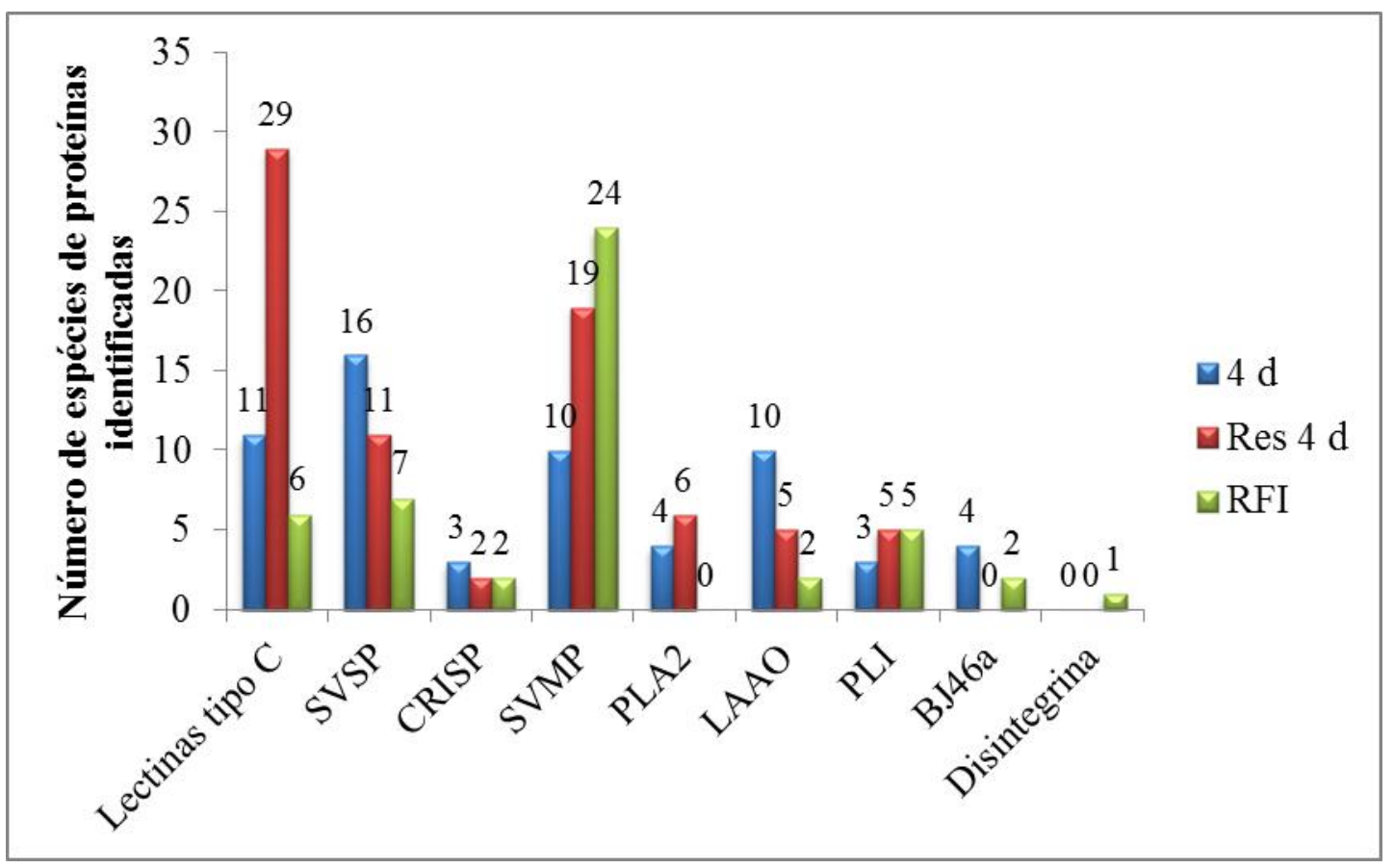

Glândulas de veneno no estágio ativado 4 dias (4 d) após a extração de veneno, tratadas com reserpina por 4 dias (Res $4 \mathrm{~d}$ ) e tratadas com reserpina, fenilefrina e isoprenalina. Diferentes classes de toxinas foram identificadas: Lectina tipo C, Serinoproteinases do veneno de serpentes (SVSP), Proteínas Secretadas Ricas em Cisteínas (CRISP), Metaloproteinases do veneno de serpentes (SVMP), Fosfolipases $\mathrm{A}_{2}\left(\mathrm{PLA}_{2}\right)$, L-aminoácido oxidase (LAAO), Inibidores de Fosfolipases $\mathrm{A}_{2}$ (PLI), Fator Anti-hemorrágico Bj46a (Bj46a). Observe que a síntese de CTLs e PLA $A_{2}$ foi regulada negativamente e Bj46a foi regulado positivamente pela inervação noradrenérgica. Os números acima das colunas indicam o número de espécies de proteínas identificadas.

Avaliando a classe das toxinas lectinas tipo C separadamente, somente as CTLssímiles foram reguladas, ou seja, notamos que o número de espécies de proteínas identificadas como GPIb-BP e do fator de coagulação IX/X aumentou significativamente após o tratamento com reserpina (Figura 23A), assemelhando-se ao estado quiescente da glândula de veneno (Figura 14A). As classes das SVMP também foram analisadas, e após o tratamento com reserpina o número de espécies de proteínas identificadas como SVMP-PII aumentou e como SVMP-PI diminuiu quando comparado com 4 dias após extração de veneno. Quando realizado o tratamento com os agonistas de adrenoceptores alfa e beta, o número espécies de proteínas identificadas como SVMP-PII reduziu e como SVMP-PI aumentou, sugerindo que a inervação noradrenérgica está regulando positivamente a síntese de SVMP-PI e negativamente a síntese de SVMP-PII e (Figura 23B). Em relação à SVMP-PIII, o tratamento com reserpina aumentou o número das espécies de proteína, no entanto, o posterior tratamento 
com os agonistas de adrenoceptores alfa e beta não reverteu esse efeito, indicando que a estimulação da inervação noradrenérgica não está envolvida na síntese dessa toxina.

Figura 23 - Toxinas identificadas na glândula de veneno da serpente Bothrops jararaca estimuladas pela inervação noradrenérgica.
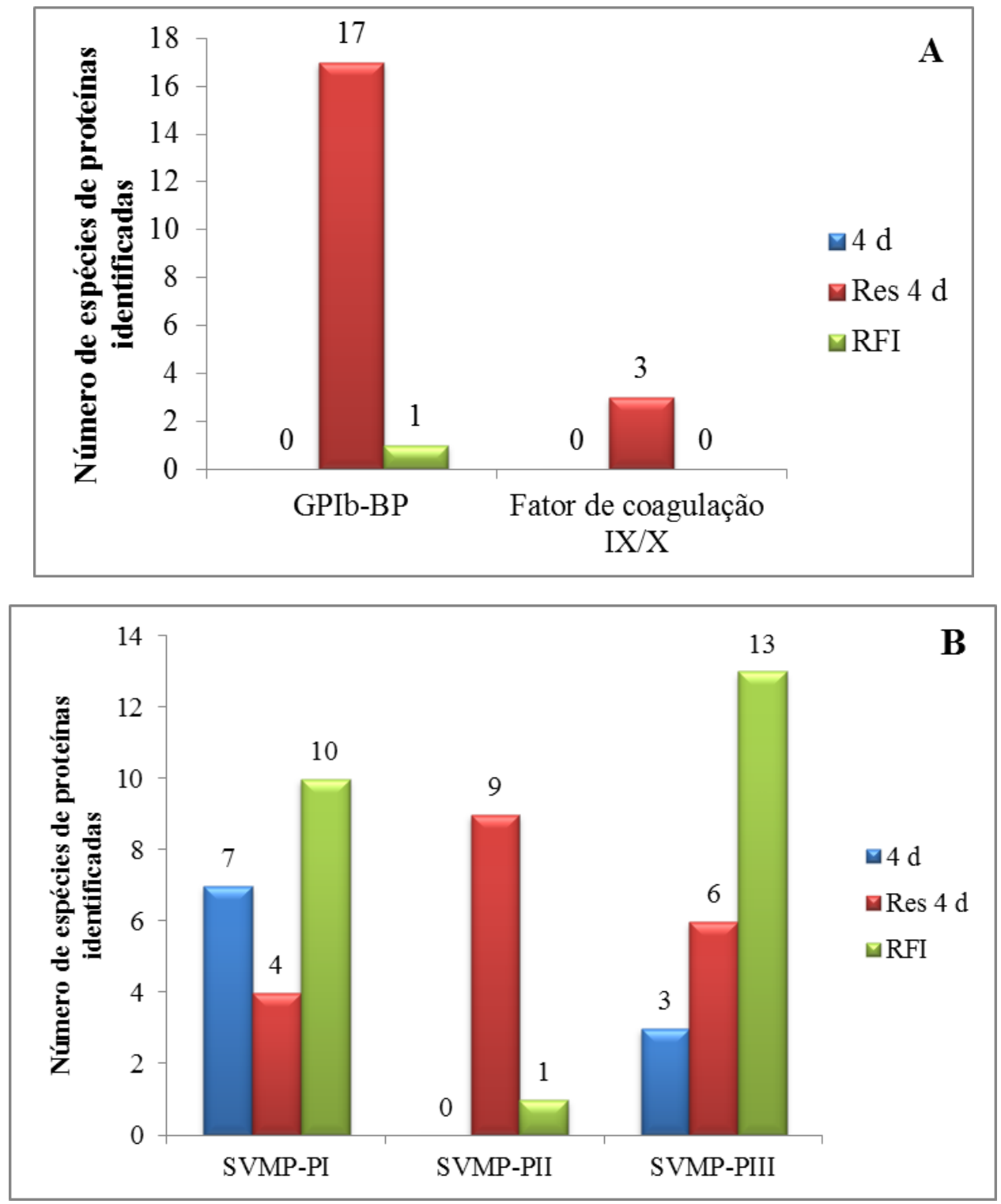

Glândula de veneno no estágio ativado 4 dias (4 d) após a extração de veneno, tratadas com reserpina por 4 dias (Res $4 \mathrm{~d}$ ) e tratadas com reserpina, fenilefrina e isoprenalina. (A) Toxinas da família das CTL-símile. (B) Toxinas da classe das metaloproteinases do veneno de serpentes (SVMP). Proteína ligante da glicoproteína-Ib (GPIb-BP). Os números acima das colunas indicam o número de espécies de proteínas identificadas 


\subsection{Perfil eletroforético da glândula acessória durante o ciclo de produção de secreção}

As glândulas acessórias pertencem ao aparelho glandular de veneno e pouquíssimos estudos existem sobre esta estrutura. Recentemente através do estudo morfológico da glândula acessória foi possível evidenciar que esta glândula também apresenta um longo ciclo de produção de secreção e que a secreção da glândula acessória só inicia uma hora após a extração de veneno, sendo que a secreção máxima ocorre 4 dias após a extração de veneno, sugerindo que ela não contribui para o veneno total (SAKAI; CARNEIRO; YAMANOUYE, 2012). Sabemos ainda que a extração de veneno leva à ativação da glândula de veneno promovendo alterações no perfil proteico desta glândula, sendo as diferenças mais significativas encontradas 4 e 7 dias após a extração de veneno para glândulas de serpentes fêmeas e machos, respectivamente (LUNA et al., 2009). Em vista destes dados, nós fomos verificar se a extração de veneno altera o perfil proteico desta glândula. Através do 1-DE foram identificadas alterações no perfil proteico. Notamos, por exemplo, que bandas proteicas de 125 e 113 kDa aumentaram a densidade durante o ciclo de produção de secreção, e a presença de duas bandas de 19 e 16 kDa que tiveram sua densidade reduzida após a extração de veneno (Figura 24 e Tabela 2). 
Figura 24 - Perfil proteico dos extratos de glândulas acessórias das serpentes Bothrops jararaca durante o ciclo de produção de secreção.

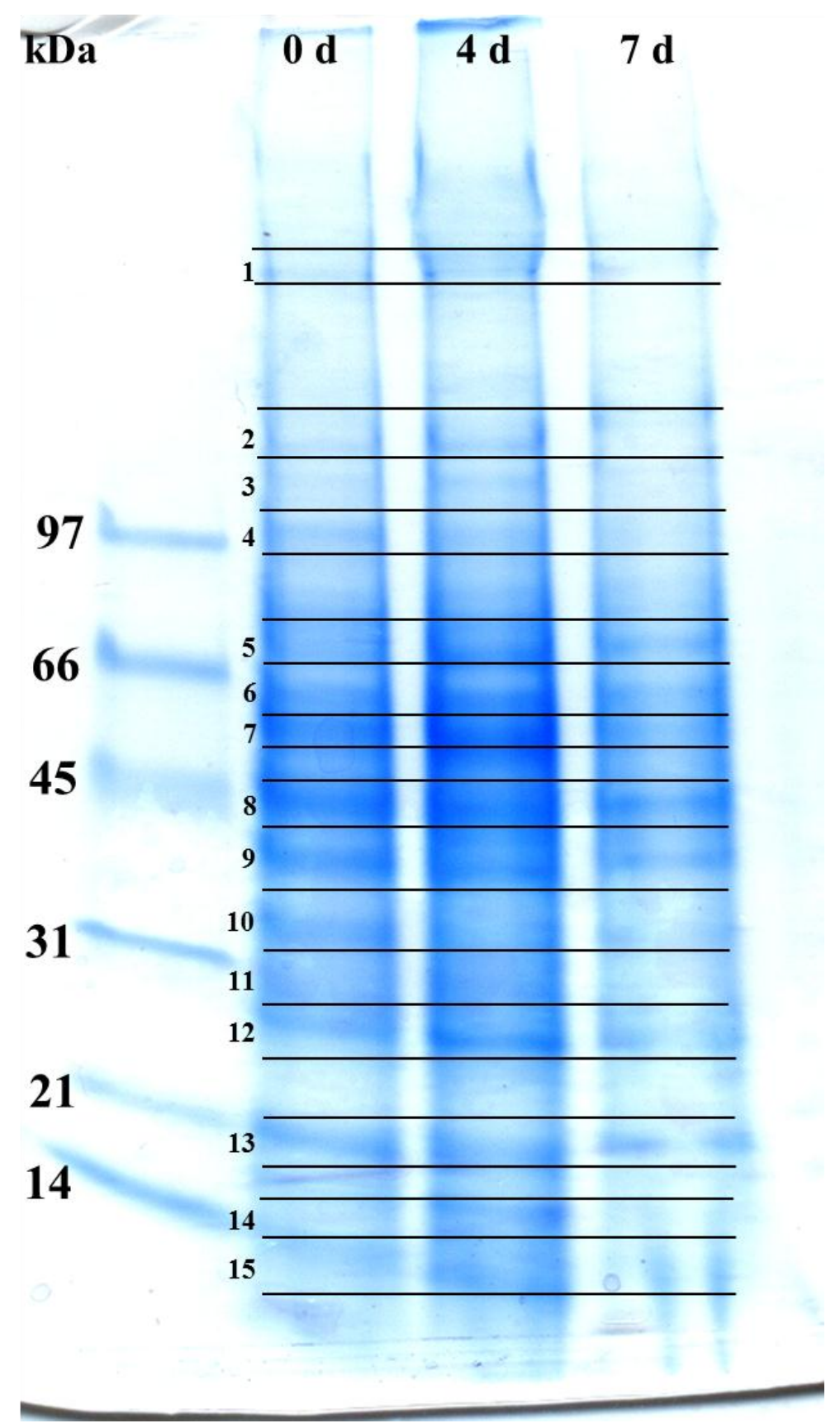

Glândula acessória sem extração de veneno (0 d) e glândulas acessórias 4 dias (4 d) e 7 dias (7 d) após a extração de veneno. A relação numérica é referente às fatias de bandas do gel 1-DE do extrato de glândula acessória que foram submetidas ao ESI-LTQ/Orbitrap XL. Massa relativa em kDa. 
Tabela 2 - Análise densitométrica das bandas dos extratos de glândulas acessórias de serpentes Bothrops jararaca sem extração de veneno (0 dia) e glândulas acessórias 4 e 7 dias após a extração de veneno.

\begin{tabular}{|c|c|c|c|c|}
\hline \multirow{2}{*}{$\begin{array}{l}\text { Número da } \\
\text { banda }\end{array}$} & \multirow{2}{*}{$\begin{array}{c}\text { Peso } \\
\text { Molecular } \\
\text { (kDa) }\end{array}$} & \multicolumn{3}{|c|}{ Densidade das bandas } \\
\hline & & 0 dia & 4 dias & 7 dias \\
\hline 1 & 211 & 14,46 & 17,39 & 18,97 \\
\hline 2 & 125 & 16,99 & 44,47 & 64,99 \\
\hline 3 & 113 & 17,45 & 34,35 & 51,97 \\
\hline 4 & 97 & 28,07 & 34,39 & 27,02 \\
\hline 5 & 75 & 41,81 & 43,62 & 46,54 \\
\hline 6 & 68 & 48,06 & 52,53 & 65,81 \\
\hline 7 & 59 & 60,82 & 64,49 & 67,29 \\
\hline 8 & 54 & 73,01 & 74,01 & 80,69 \\
\hline 9 & 44 & 65,61 & 74,18 & 71,72 \\
\hline 10 & 38 & 47,87 & 37,96 & 56,51 \\
\hline 11 & 32 & 31,86 & 39,02 & 38,92 \\
\hline 12 & 26 & 28,67 & 47,12 & 37,15 \\
\hline 13 & 19 & 31,82 & 27,17 & 23,76 \\
\hline 14 & 16 & 27,15 & 17,82 & 16,76 \\
\hline 15 & 12 & 20,08 & 37,55 & 32,00 \\
\hline
\end{tabular}

As densidades na tabela escritas em vermelho aumentaram após a extração de veneno e as densidades escritas em azul diminuíram após a extração de veneno. 


\subsection{Identificação das proteínas da glândula de acessória}

Na literatura não existem dados referentes às proteínas da glândula acessória, portanto, para uma melhor análise desta estrutura, todas as bandas proteicas foram recortadas e submetidas à espectrometria de massas do tipo ESI-LTQ/Orbitrap XL. Para identificação destas bandas, o gel foi fatiado sequencialmente e estas estão enumeradas como demonstrado na Figura 24. As proteínas identificadas foram classificadas de acordo com a localização subcelular obtida no banco de dados UniProt (www.uniprot.org.br) e a relação destes dados pode ser visualizada nos apêndices 6-8 presentes deste trabalho.

Somente as proteínas que obtiveram como resultado o FDR menor ou igual a $1 \%$ foram consideradas como uma identificação confiável. A porcentagem de proteínas identificadas de cada compartimento subcelular foi avaliada sobre o número total de proteínas identificadas. Notamos uma redução na porcentagem de proteínas do retículo endoplasmático e um aumento na porcentagem de proteínas nucleares e mitocondriais após a extração de veneno. Surpreendentemente, identificamos também uma grande quantidade de proteínas secretadas, identificadas como toxinas, na glândula acessória em todos os grupos estudados, como podem ser visualizadas na Figura 25 (A, B, C). 
Figura 25 - Distribuição subcelular das proteínas identificadas nas glândulas acessórias de serpentes Bothrops jararaca durante o ciclo de produção de secreção.
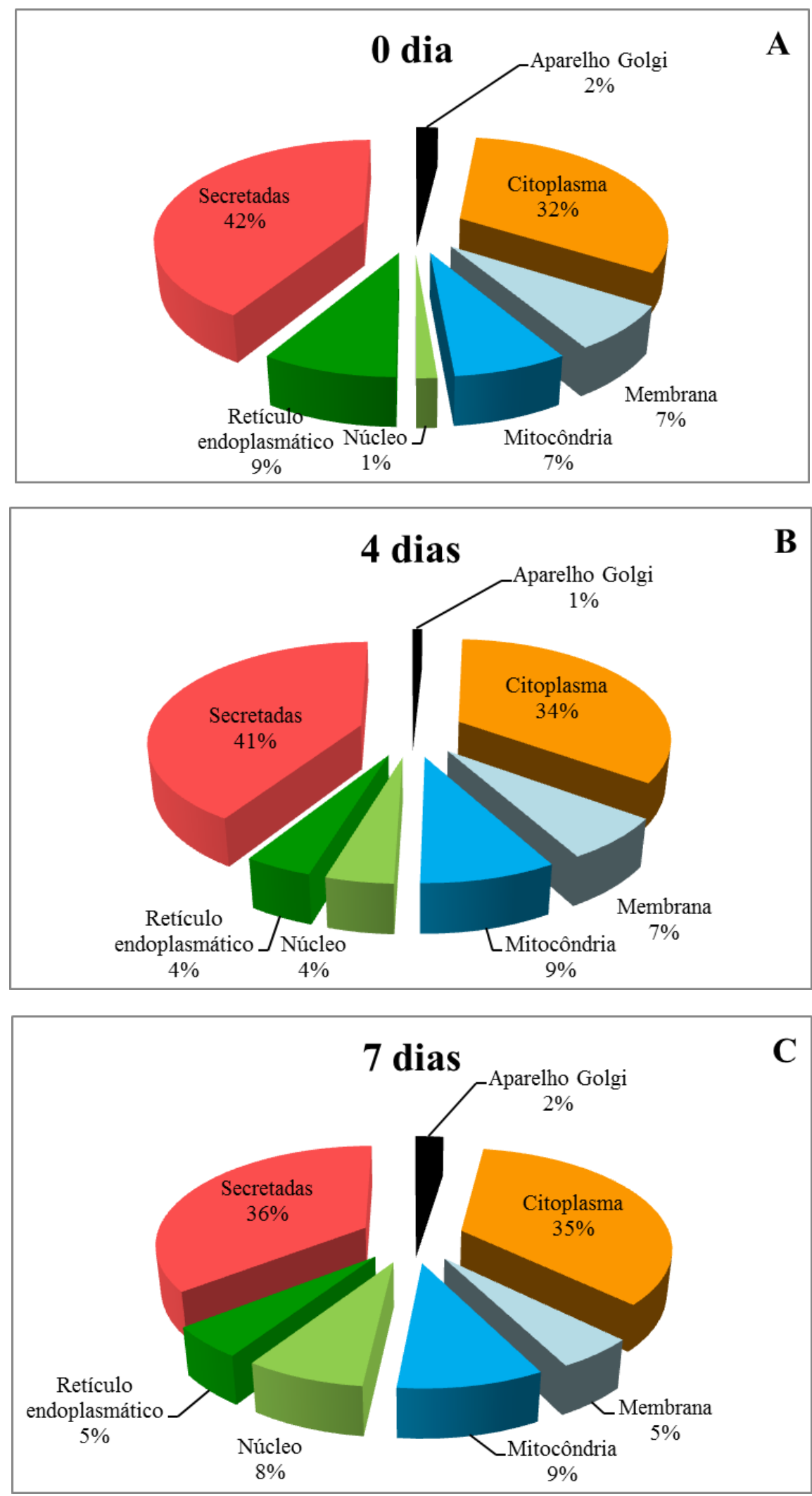

(A) Glândula acessória sem extração de veneno (0 d), glândulas acessórias 4 dias (4 d) (B) e 7 dias (7 d) (C) após extração de veneno. A classificação das proteínas foi obtida no banco de dados UniProt. 
Avaliando cada compartimento subcelular separadamente notamos que o número de proteína nuclear identificada como histona $\mathrm{H} 2$ aumentou após a extração de veneno (Figura 26). E a síntese das proteínas de membrana identificada como dipeptidil peptidase $4 \mathrm{~b}$ (DPPIV) e de proteínas do retículo endoplasmático identificado como heat shock 90 (HSP90) reduziu após a extração de veneno, como demonstrado na Figura 26.

Figura 26 - Número de espécies de proteínas identificadas na glândula acessória da serpente Bothrops jararaca que tiveram suas sínteses alteradas durante o ciclo de produção de secreção.

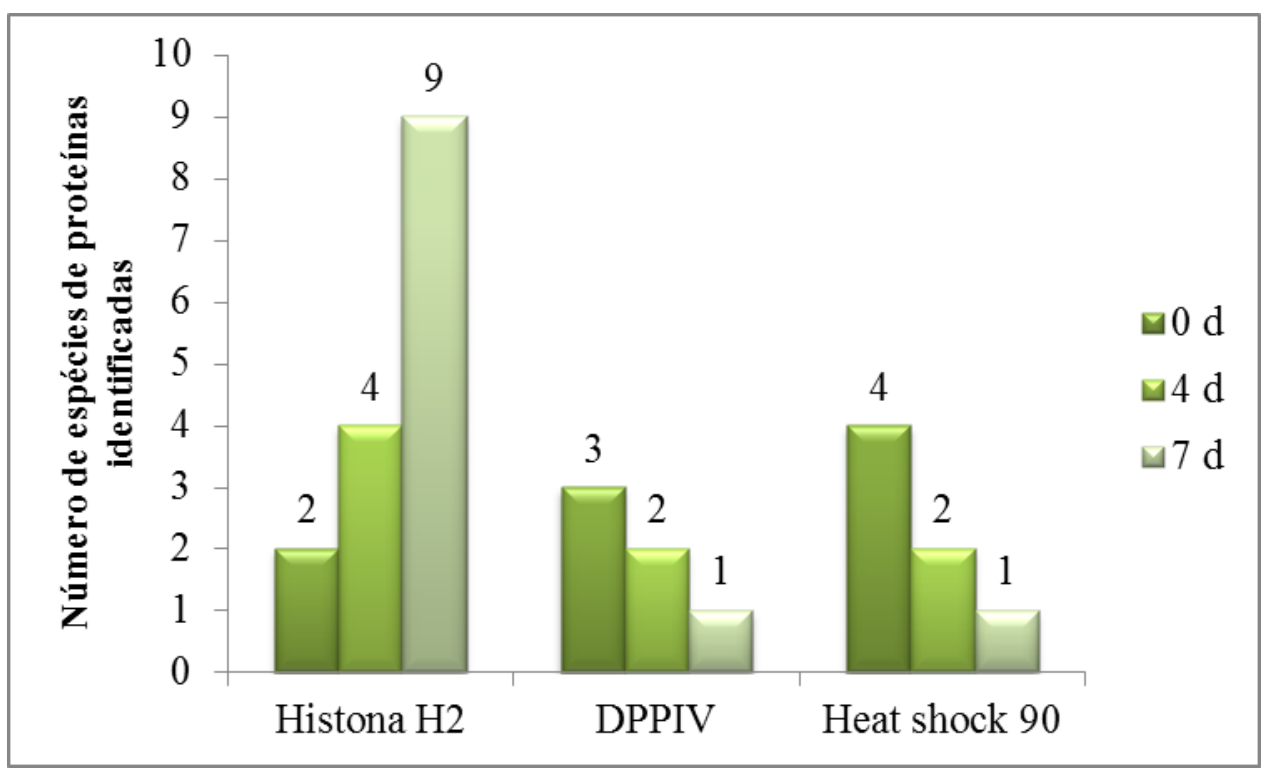

Glândula acessória sem extração de veneno (0 d), glândulas acessórias 4 dias $(4$ d) e 7 dias (7 d) após a extração de veneno. Histona H2 (proteína nuclear), dipeptidil peptidade 4b (DPPIV, proteína de membrana) e Heat shock 90 (proteína do retículo endoplasmático). Os números acima das colunas indicam o número de espécies de proteínas identificadas.

Em relação às proteínas secretadas da glândula acessória, a porcentagem de espécies de proteínas identificadas como proteínas do veneno, reduziu após o início do ciclo de produção de veneno, como podemos notar na Figura 25.

Analisando as proteínas identificadas dentro de cada classe de toxina, notamos que a expressão também ocorre de maneira não sincronizada. Pela primeira vez estamos mostrando que glândula acessória secreta toxinas, igualmente as identificadas na glândula principal de veneno (Figura 13). Assim como mostrado na glândula de veneno, as toxinas também estão presentes na glândula acessória que não sofreram extração de veneno, tais como lectinas tipo C, SVSP, SVMP, PLA 2 , LAAO, PLI, Bj46a e disintegrinas, além das proteínas glutaminil ciclase (GC), peptídeo natriurético $(\mathrm{PN})$ e o precursor do tri-peptídeo inibidores de 
metaloproteinases (pEKW) identificadas apenas na glândula acessória não sofreram extração (Figura 27A).

Quatro dias após a extração de veneno notamos que o número de espécies de proteínas identificadas como toxinas reduziu, exceto das SVMP-PII e SVMP-PIII e do Bj46a. Sete dias após a extração de veneno, verificamos que o número de espécies de proteínas identificadas como -lectinas tipo $\mathrm{C}$ foi semelhante à glândula acessória sem extração de veneno e as proteínas identificadas como PLI tiveram um aumento discreto (Figura 27A e C). As CTLs foram identificadas somente no $7^{\circ}$ dia após extração de veneno. Entre as CTLs-símiles todas foram identificadas na glândula acessória de serpentes que não sofreram extração de veneno, no entanto, somente as GPIB-BP foram identificadas no $4^{\circ}$ dia após a extração de veneno, as demais CTL-símiles foram identificadas na glândula acessória também no $7^{\circ}$ dia após extração de veneno (Figura 27B).

Analisando as classes das SVMP identificadas na glândula acessória, notamos que ao contrário das CTL-símile, as classes de SVMP-PII e SVMP-PIII foram identificadas preferencialmente no $4^{\circ}$ dia após a extração de veneno, no entanto, nenhuma SVMP-PI foi identificada nessa glândula (Figura 27C). 
Figura 27 - Número de proteínas secretadas identificadas na glândula acessória da serpente Bothrops jararaca.
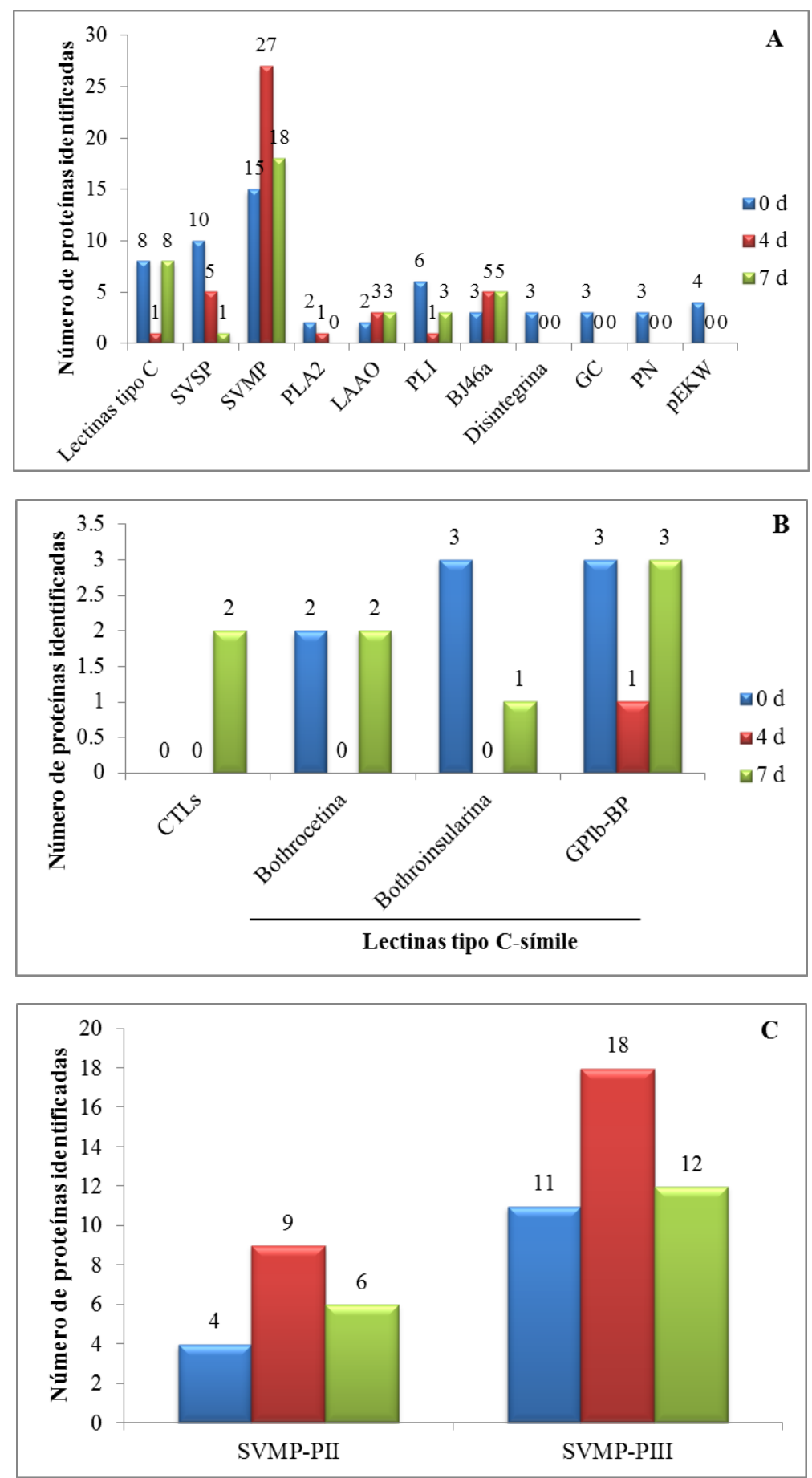

Glândulas acessórias sem extração de veneno $(0$ d), glândulas acessórias 4 dias $(4$ d) e 7 dias $(7$ d) após a extração de veneno. (A) Diferentes classes de toxinas identificadas. (B) Classe das Lectinas tipo C. (C) Classe das metaloproteinases do veneno de serpentes (SVMP). Proteínas identificadas como Serinoproteinases do veneno de serpentes (SVSP), Metaloproteinases do veneno de serpentes (SVMP), Fosfolipases $\mathrm{A}_{2}\left(\mathrm{PLA}_{2}\right)$, L-aminoácido oxidase (LAAO), Inibidores de Fosfolipases $\mathrm{A}_{2}$ (PLI), Fator Anti-hemorrágico Bj46a (Bj46a), Glutaminil ciclase (GC), Peptídeo natriurético (PN) e o precursor do tri-peptídeo inibidor de metaloproteinases (pEKW). Os números acima das colunas indicam o número de espécies de proteínas identificadas. 


\section{${ }_{5}$ DISCUSSÃO}


O estudo do proteoma das glândulas principal de veneno e acessória da serpente Bothrops jararaca revelou vários dados inéditos. A detecção de toxinas do veneno no estado quiescente da glândula principal de veneno e na glândula acessória e a participação da inervação noradrenérgica na regulação da síntese de várias proteínas da glândula de veneno, bem como das toxinas, trazem novos conceitos para os mecanismos de produção e secreção de veneno. Esses dados muito contribuirão para a compreensão dos mecanismos celulares envolvidos no desencadeamento da síntese e secreção de veneno, ou seja, para a funcionalidade dessas glândulas e para o estudo da diversidade de toxinas presentes no veneno.

\subsection{Síntese de proteínas no ciclo de produção de veneno}

Sabemos da importância da inervação noradrenérgica no desencadeamento do ciclo de produção e secreção de veneno, no entanto, pouco se conhece sobre as proteínas que participam da ativação da glândula para produção e secreção de veneno. A nossa primeira análise dos spots específicos presentes em cada estágio do ciclo de veneno avaliado, já nos mostrou que está ocorrendo uma regulação na síntese das proteínas da glândula de veneno corroborando com dados mostrados anteriormente por nosso grupo (LUNA et al., 2009).

Neste estudo, mostramos pela primeira vez que a maioria das toxinas estão presentes no estágio quiescente da glândula de veneno e que algumas proteínas como a GPIb-BP e o fator de coagulação IX/X estão presentes apenas no estágio quiescente da glândula de veneno. Mostramos ainda que após a extração de veneno a síntese das serinoproteinases e lectinas tipo C diminuiu e a síntese das SVMP, PLA 2 , LAAO, PLI, fator anti-hemorrágico Bj46a e disintegrinas aumentou. Além disso, ocorreu um aumento na síntese de algumas proteínas citoplasmáticas como a subunidade alfa do proteassomo e tioredoxina, proteína $40 \mathrm{~S}$ ribossomal e actina, vimentina e tropomiosina após o início do ciclo de produção de veneno. A síntese das proteínas do retículo endoplasmático como PDI e GRP78 também aumentaram após o início do ciclo de produção de veneno.

Sabemos que as células secretoras da glândula de veneno de serpentes Viperidae passam por mudanças morfológicas que são reguladas pela quantidade de veneno acumulada no lúmen da glândula (BEN-SHAUL et al., 1971; KOCHVA; GANS, 1970; KOCHVA, 1978; ORON; BDOLAH, 1973) e pelo sistema nervoso simpático 
(YAMANOUYE et al., 1997). Durante primeira semana após a extração de veneno, as cisternas do reticulo endoplasmático das células secretoras estão expandidas, resultando em um aumento do volume e altura da célula. Essas alterações morfológicas são acompanhadas por um aumento de membrana de várias organelas e de mitocôndrias (CARNEIRO et al., 1991). O aumento de atividade celular requer um aumento da síntese de proteínas para a manutenção da homeostase celular, bem como a síntese de novas toxinas. Portanto, modificações pós-traducionais, a síntese, degradação e secreção de proteínas são processos importantes na homeostasia celular que garantem o controle de qualidade das proteínas recém-sintetizadas e o seu endereçamento correto. Portanto, o aumento no número de espécies de proteínas como actina, vimentina, tropomiosina, subunidade alfa do proteassomo, proteína 40S ribossomal, tioredoxina, PDI e GRP78 nos estágios ativados da glândula de veneno sugere que estas proteínas podem estar atuando de forma a implementar o processo de síntese e secreção nas células secretoras da glândula de veneno devido ao aumento de atividade das células secretoras

Dentre as proteínas citoplasmáticas, identificamos proteínas do citoesqueleto como a actina, a vimentina e a tropomiosina. O citoesqueleto é uma rede altamente complexa de três filamentos intracelulares: microfilamentos, filamentos intermediários e microtúbulos (WETTESTEIN et al., 2012). A actina é o maior elemento estrutural do citoesqueleto e está envolvida na organização do citoesqueleto e na regulação da secreção de saliva (KONGO et al., 2008; NASHIDA et al., 2004; PERRIN et al., 1992; SEGAWA et al., 1998). A polimerização globular dos monômeros de actina-G formam os filamentos de actina-F, o qual tem um papel importante nas funções celulares mais complexas incluindo o transporte intracelular de organelas e vesículas, citocinese, apoptose e motilidade celular. As tropomiosinas pertencem a uma família de proteínas associadas às actinas e que tem a função de estabilizar os filamentos de actina, prevenindo a despolimerização e tornando os filamentos mais fortes e menos suscetíveis a quebra. Estas propriedades são importantes para as células não musculares, onde os filamentos de actina se agrupam rapidamente, movem-se e se dissociam em diferentes tempos e lugares (COOPER, 2002; LESS et al., 2011).

A vimentina é a principal proteína do filamento intermediário das células mesenquimais é altamente conservada nos vertebrados, e apresenta um padrão de expressão variável durante o desenvolvimento e a diferenciação (COGLI et al., 2013). A vimentina exerce um papel importante nos processos fisiopatológicos tanto na homeostase da célula normal como na inflamação, apoptose entre outras injúrias. A 
vimentina age como um organizador de várias proteínas críticas envolvidas na adesão, migração e sinalização intracelular, além disso, também podem atuar como um potente regulador da transcrição, interagindo e sequestrando fatores transcripcionais e dessa forma, cooperando com fatores de transcrição como AP-1 e junD (IVASKA et al., 2007).

Em células acinares de parótida no estado basal, as proteínas do citoesqueleto fodrina e actina parecem ser uma continuação da membrana plasmática na maioria das células e quando estimuladas com secretagogos, as proteínas praticamente desaparecem. Estas alterações ocorrem em paralelo com a secreção de amilase (PERRIN et al., 1992). Estudos que investigam o papel do citoesqueleto e de proteínas motoras no processo secretório de glândulas salivares, mostraram que a secreção de amilase depende da integridade dos microfilamentos, uma vez que o tratamento com jaspakinolide e citochalasin D, agente estabilizador e desestabilizador de actina respectivamente, diminuíram a secreção de amilase induzida por ambos agonistas de adrenoceptor beta e colinérgico-muscarínico (BUSCH el al., 2002; NASHIDA et al., 2004). Além disso, isoprenalina induz a secreção e a reorganização do citoesqueleto via um aumento de cálcio citosólico livre e AMPc em células acinares de parótida (PERRIN et al., 1992).

Em nosso trabalho, mostramos que a síntese de proteínas do citoesqueleto em glândulas de veneno está aumentada nos estágios ativados. Portanto, nossos resultados sugerem que a reorganização do citoesqueleto tem um papel importante na ativação da glândula de veneno e a secreção de veneno.

As proteínas PDI e GRP78 são chaperonas presentes no retículo endoplasmático que são recrutadas quando a homeostase do retículo endoplasmático está alterada (WANG et al., 2012). As PDIs constituem uma família estruturalmente relacionada com enzimas na qual catalisam a formação de pontes dissulfeto, redução ou isomerização de proteínas recém-sintetizadas no lumen do retículo endoplasmático. A expressão de PDI é rapidamente induzida sob diferentes estresses ao retículo endoplasmático indicando um papel importante da PDI no controle de qualidade que se estende além de ligações dissulfeto (DORNER et al., 1990; MAATTANEN et al., 2010). GRP78 é encontrada em uma variedade de células secretoras, portanto, podem ter diferentes funções como nas modificações pós-traducionais, no agrupamento e no empacotamento de proteínas antes delas serem secretadas e também podem participar do mecanismo secretório (BEATON; WILKINS; WHEELER, 1997; MUNRO; PELHAM, 1986). 
Após a extração de veneno, a glândula de veneno é ativada e um novo ciclo de produção e secreção é iniciado, em outras palavras, as células secretoras estão com uma alta taxa de síntese proteica. Portanto, o aumento de síntese de PDI e GRP78 nas glândulas ativadas pode ter um papel importante coordenando o dobramento, modificações pós-traducionais e transporte de proteínas na glândula de veneno e provavelmente estão envolvidas no processo de síntese e secreção de veneno. Nossos dados corroboram com um estudo realizado recentemente onde sugere que o transcriptoma do veneno pode ser um representativo do transcriptoma das glândulas de veneno. Neste estudo foi mostrado que a expressão de PDI está aumentada nos estados ativados da glândula de veneno (CURRIER et al., 2012).

As células estão frequentemente expostas a agentes químicos e físicos que podem levar a uma formação incorreta das proteínas e com isso a formação de agregados proteicos, morte celular e estresse oxidativo. Nas células eucarióticas a degradação das proteínas intracelulares ocorre no sistema ubiquitina-proteassomo, um sistema não lisossomal de degradação de proteínas. Nos casos onde o estresse oxidativo não é muito severo, enzimas como a tioredoxina (Trx) são recrutadas para reduzir as proteínas oxidadas (KRIEGENBURG et al., 2011). A Trx é uma proteína de $12 \mathrm{kDa}$, encontrada principalmente no citoplasma e ocasionalmente no núcleo. TRX é uma proteína antioxidante ubíqua muito conhecida por sua atividade disulfide redutase, no entanto a Trx também é capaz de realizar transnitrosilação e desnitrosilação (processos definidos como a transferência e remoção de oxido nítrico de substratos) em espécies de proteínas, interações proteína-proteína e modificações pós-traducional (para revisão ver WU et al., 2011). Estes dados sugerem que a alta síntese de Trx identificada nos estágios ativados da glândula de veneno pode estar relacionada com a estrutura correta das proteínas e as modificações pós-traducionais das proteínas recém-sintetizadas.

Por outro lado, quando o dano proteico é severo ou irreversível, as proteínas são direcionadas para degradação no sistema ubiquitina-proteassomo, servindo como um controle geral da qualidade da proteína na célula. O proteassomo $26 \mathrm{~S}$ é uma molécula estável, composta por dois subcomplexos: a subunidade catalítica $20 \mathrm{~S}$ e a subunidade regulatória 19S. O subcomplexo $20 \mathrm{~S}$ possui sete subunidades alfa $(\alpha 1-\alpha 7)$ e sete subunidades beta ( $\beta 1-\beta 7)$. O proteassomo $26 \mathrm{~S}$ é responsável pela degradação de proteínas oxidadas e ubiquitinadas (para revisão ver KRIEGENBURG et al., 2011, MATYSKIELA; MARTIN, 2013). Na glândula de veneno ativada, identificamos um aumento das espécies de subunidade alfa do proteassomo e estas subunidades 
especificamente são importantes no controle da abertura do poro do proteassomo, ou seja, elas regulam o acesso à parte interna da cavidade do proteassomo (MATYSKIELA; MARTIN, 2013).

Os ribossomos estão entre as maquinarias moleculares mais importantes em todas as células para a síntese de proteínas. Nos eucariotos, as subunidades ribossomais 40S e a 60S se ligam no códon iniciador do RNAm, e no iniciador metionil do RNAt no sítio do peptidil (P), dando início ao processo de tradução. Através da microscopia de congelamento, foi demonstrado que a subunidade 40S liga-se aos fatores de iniciação (elF1 e elF1A) e estabilizam as alterações conformacionais que abrem os canais para o RNAm e iniciam a tradução (PASSMORE et al., 2007). Portanto, o aumento das espécies de proteínas ribossomais nos estágios ativados da glândula de veneno, provavelmente está relacionado com o aumento da síntese de novas proteínas/toxinas nesta glândula.

Diversos estudos têm demonstrado que após a extração de veneno, ou seja, a liberação do veneno do lumen da glândula promove alterações morfológicas e bioquímicas no epitélio secretor. A atividade sintética máxima das células secretoras tem sido observada entre $4^{\circ}$ e $8^{\circ}$ dia após o inicio do ciclo de produção de veneno e neste estágio foi encontrado uma alta concentração de RNAm (BEN-SHAUL; LIFSHITZ; KOCHVA, 1971, CARNEIRO et al., 1991, DE LUCCA et al., 1974, KOCHVA, 1978, ORON; BDOLAH, 1973, ROTENBERG; BAMBERGER; KOCHVA, 1971). Pouco se conhece sobre a síntese de toxinas do veneno, no entanto, parece que a síntese e secreção para o lumen de diferentes toxinas ocorrem de maneira não sincronizada (BROWN et al., 1975). Em relação às toxinas identificadas, mostramos pela primeira vez que a maior parte das toxinas está presente no estágio quiescente e que algumas delas estão presentes exclusivamente neste estágio, tais como a GPIb-BP o fator de coagulação IX/X e a enzima trombina-símile. A presença de SVMP no estágio quiescente também foi demonstrada na glândula de veneno de serpentes Bothrops jararaca através da técnica de microscopia eletrônica (CARNEIRO et al., 2002). Além disso, Currier et al (2012) observaram pouca diferença na composição do veneno e atividade enzimática do veneno analisado desde do dia 0-1 até o considerado maduro (25dias). Esses dados sugerem que após a extração de veneno, as toxinas presentes no estado quiescente são exocitadas para o lumen, visto que as proteínas envolvidas na secreção estão aumentadas nos estágios ativados da glândula de veneno. 
Diferentes espécies de toxinas foram identificadas no estágio ativado da glândula de veneno como espécies de SVMP-PII no estágio ativado 7 dias, no entanto, algumas delas são mais abundantes no estágio quiescente como espécies de SVSP. Como a maior parte dos estudos moleculares e de transcriptoma utilizam as glândulas de veneno ativada 4 dias, provavelmente estes estudos estão perdendo informações importantes sobre a diversidade das toxinas. Provavelmente a transcrição do DNA destas toxinas presentes no estágio quiescente ocorra posteriormente. Considerando que apenas os spots específicos em cada estágio foram identificados, os dados presentes neste estudo, indicam claramente que as diferentes espécies de toxinas são secretadas de forma independente uma da outra, sugerindo que a síntese e secreção de toxinas ocorrem de maneira não sincronizada, corroborando com os dados já demonstrados por Oron e Bdolah, 1973. Por outro lado, recentemente, um estudo avaliou a dinâmica de expressão gênica do veneno após a extração de veneno analisando o RNAm presente no veneno, mostrou que o pico de expressão de RNAm de diversas classes de toxinas do veneno ocorre de forma paralela entre o $3^{\circ}$ e $7^{\circ}$ dia após o início do ciclo de produção de veneno (CURRIER et al., 2012).

Outra classe de toxina identificada na glândula de veneno foi das proteínas do veneno ricas em cisteína (CRISP-Vs), porém a sua síntese não foi alterada durante o ciclo de produção de veneno. As CRISP-Vs pertencem à família das CRISPs - cysteinerich secretory protein (RAMAZANOVA et al., 2008), que compreendem uma classe de proteínas inicialmente encontradas no epidídimo de mamíferos e expressas em uma variedade de organismos (OOKUMA et al., 2003; SCHREIBER et al., 1997). As CRISPs são proteínas de cadeia única, com massa molecular entre $20 \mathrm{kDa}$ a $30 \mathrm{kDa}$ e uma grande quantidade de resíduos de cisteína fortemente conservados em sua estrutura (YAMAZAKI; MORITA, 2004). A principal função reportada para toxinas pertencentes a esta classe é o bloqueio de canais iônicos, como canais de cálcio, por exemplo, comprometendo a atividade de contração da musculatura lisa, ou ainda que possam ter atividade neurotóxica (RAMAZANOVA et al., 2008).

Outro dado interessante encontrado neste estudo foi a identificação de inibidores de metaloproteinases, Bj46a e de fosfolipases $\mathrm{A}_{2}$ em glândulas de veneno ativadas. A presença de inibidores de metaloproteinases foi descrita somente no plasma de serpentes, sendo essa proteína sintetizada no fígado (VALENTE et al., 2001). Inibidores de metaloproteinases estão presentes no plasma de vários animais, como por exemplo, o da Bothrops jararaca, que é naturalmente resistente ao envenenamento e são 
consideradas parte do sistema imune destes animais (para revisão ver VALENTE et al., 2009; NEVES-FERREIRA et al., 2009). Uma explicação possível para presença destes inibidores nas glândulas de veneno ativadas 4 e 7 dias (Figura 13) seria uma contaminação cruzada com o veneno da serpente durante a dissecção da glândula. No entanto, se fosse este o caso, provavelmente estes inibidores seriam detectados nas glândulas quiescentes, o que não ocorreu. Outra possibilidade seria uma contaminação cruzada com o sangue durante a extração de veneno que ocorreu 4 e 7 dias antes da síntese de proteínas. Para evitar esta possibilidade, nós utilizamos apenas glândulas de veneno íntegras, ou seja, sem danos visíveis (hematomas ou inchaços). Por outro lado, o veneno acumulado dentro do lumen da glândula é uma mistura complexa de proteínas e para o controle da toxicidade do veneno muitos fatores já foram descritos como protetores das glândulas de veneno. As propriedades físico-químicas do veneno como as altas concentrações de citrato e o baixo pH (MACKESSY; BAXTER, 2006; ODELL et al., 1998; SOUSA et al., 2001; VILJOEN; BOTES, 1979) além da secreção de enzimas inativas precursoras de zimogênios e a expressão de peptídeos endógenos como as inibidores específicos de enzimas do veneno (WAGSTAFF et al., 2008). A presença destes inibidores na glândula de veneno da serpente Bothrops jararaca é maior nas glândulas de veneno ativadas 4 dias, portanto, podem estar atuando na manutenção das metaloproteinases e $\mathrm{PLA}_{2}$ miotóxicas na forma inativa dentro do lumen e assim promovendo um novo mecanismo de controle da toxicidade do veneno durante a síntese e a estocagem do veneno. Dados recentes não publicados, dos nossos colaboradores determinaram que a interação entre o BJ46a (SVMPI) e a jararhagina (P-III SVMP) tem uma constante de dissociação $\left(K_{d}\right)$ baixa na ordem de nanomolar. Este tipo de associação é uma interação não covalente muito forte que não pode ser facilmente quebrada e a eficácia do veneno pode ser prejudicada. Portanto, parece que a presença destes inibidores estabiliza e inativa a autólise das proteínas, assim protegendo as serpentes contra os próprios componentes do veneno.

\subsection{Participação da inervação noradrenérgica regulando a síntese de proteínas na glândula de veneno}

A reserpina tem sido utilizada como ferramenta farmacológica para desvendar o papel da inervação simpática em glândulas salivares ou de veneno. Em ratos, o tratamento crônico com esta droga promove alterações morfológicas e funcionais 
irreversíveis em glândulas salivares, similar às alterações encontradas em pacientes com fibrose cística (MARTINEZ et al., 1975a,b; WATSON et al., 1984). Em serpentes, o tratamento crônico com reserpina promoveu alterações morfológicas e bloqueou a produção e secreção de veneno em glândulas ativadas pela extração de veneno. No entanto esse efeito foi revertido com a posterior administração crônica de isoprenalina e fenilefrina, restaurando a síntese proteica do veneno, mas apenas a fenilefrina é capaz de restaurar o processo de secreção de proteínas do veneno (YAMANOUYE et al., 1997). Dados anteriores do laboratório mostraram também que após a extração de veneno, a noradrenalina é liberada e atuando em adrenoceptores $\alpha$ e $\beta$ ativa a glândula de veneno (KERCHOVE et al., 2004; LUNA et al., 2009; YAMANOUYE et al., 2000; ZABLITH, 2007). A ativação desses receptores desencadeia a sinalização intracelular culminando na ativação de fatores de transcrição NFkB e AP-1 que irão regular a síntese de proteínas, ativando a glândula de veneno (KERCHOVE et al., 2008; LUNA et al., 2009; ZABLITH, 2007).

Com a utilização da reserpina verificamos que a inervação noradrenérgica regula a síntese de proteínas importantes para a ativação da glândula de veneno para a produção e secreção de toxinas. O tratamento com reserpina promoveu uma redução na quantidade de spots específicos presentes na glândula de veneno e após o tratamento com os agonistas de adrenoceptores alfa e beta verificamos um aumento na quantidade de spots específicos, e um aumento na quantidade de spots específicos entre a glândula de veneno ativada 4 dias e a glândula tratada com reserpina e agonistas de adrenoceptores $\alpha$ e $\beta$, sugerindo a participação da inervação noradrenérgica na regulação da síntese de proteínas da glândula de veneno, corroborando com dados mostrados anteriormente por nosso grupo (LUNA et al., 2009).

A estimulação da inervação noradrenérgica promoveu uma regulação da síntese das proteínas do citoplasma tais como vimentina, tropomiosina, subunidade alfa do proteassomo, anexina A5, da cadeia leve da miosina e da proteína mitocondrial ATP sintase mitocondrial-símile. A respeito das toxinas do veneno, a estimulação da inervação noradrenérgica promoveu uma regulação negativa na síntese de algumas toxinas como a GPIb-BP, o fator de coagulação IX/X, a PLA 2 e da SVMP-PII. Não podemos descartar que a estimulação da inervação noradrenérgica promova a exocitose de GPIb-BP, o fator de coagulação IX/X, proteínas presentes somente no estado quiescente. Além disso, a estimulação da inervação noradrenérgica promoveu uma 
regulação positiva na síntese do inibidor de metaloproteinase fator anti-hemorrágico Bj46a e da SVMP-PI.

A vimentina, como descrito acima, exerce um papel importante nos processos fisiológicos tanto na homeostase da célula normal como na inflamação, apoptose entre outras injúrias. Mostramos a participação da inervação noradrenérgica na síntese de vimentina, visto que o tratamento crônico com reserpina promoveu uma redução na síntese de vimentina e a subsequente administração dos agonistas de adrenoceptores alfa e beta reverteu este efeito. Como visto anteriormente, a noradrenalina é capaz de ativar fatores de transcrição em glândula de veneno tais como AP-1 (LUNA et al., 2009) e somado ao fato da vimentina ser um potente regulador da transcrição, cooperando com fatores de transcrição como AP-1 e junD (IVASKA et al., 2007), sugere o envolvimento da vimentina na regulação do processo de síntese de proteínas na glândula de veneno.

A síntese da cadeia leve da miosina também foi regulada pela inervação noradrenérgica. Miosina é uma proteína motora dos microfilamentos e a sua presença já foi detectada em tecidos secretórios como ilhas pancreáticas, glândulas salivares e pituitárias de porcos e são muito semelhantes às miosinas de músculo liso, apresentando cadeias pesadas e leves (OSTLUND; LEUNG; KIPNIS, 1978). Diversos estudos indicam que a actina participa ativamente do transporte das vesículas secretoras e este movimento exige a presença de proteínas motoras como a miosina, formando um complexo actina-miosina. Em glândulas exócrinas o complexo actina-miosina pode atuar como uma proteína de sustentação para estabilizar e prevenir o rompimento das mesmas, no qual pode ser causado por um aumento da pressão hidrostática (PORATSHLIOM et al., 2012). Portanto, nossos resultados sugerem que a inervação noradrenergica está modulando a síntese da miosina.Como discutido anteriormente, o sistema ubiquitina-proteassomo pode ser recrutado para remoção de proteínas com danos severos e irreversíveis, servindo como um controle geral do conteúdo proteico e da qualidade da célula. A inervação noradrenérgica também atua regulando positivamente a síntese da subunidade alfa do proteassomo, sugerindo um papel importante dessa inervação para os processos de proteólise via proteassomo, atuando no controle do conteúdo proteico através da degradação de proteínas oxidadas e ubiquitinadas (para revisão ver KRIEGENBURG et al., 2011, MATYSKIELA; MARTIN, 2013).

A anexina A5 é uma proteína citosólica de $35,7 \mathrm{kDa}$, que se liga, de forma reversível, com as fosfatidilserinas (PS) expressas em membranas de modo dependente 
de cálcio. As anexinas são uma família de proteínas que se ligam à membrana e tem uma participação importante nas propriedades estruturais e atividades biológicas associadas à membrana. Apesar de ser uma proteína citosólica, a A5 já foi encontrada em superfícies celulares e na circulação, indicando que ela é liberada para o meio extracelular, no entanto, sua liberação ocorre por uma via secretória não convencional, visto que não possui a sequencia de nucleotídeos no seu RNAm que as direcione para a via secretória via aparelho de Golgi. Dessa forma, a A5 tem várias funções fisiológicas dependendo de sua localização e concentração local. Devido a sua capacidade de se ligar à PS, a A5 tem um papel relevante na apoptose, hemostasia, trombose, inflamação e nos processos imunológicos (GENDEREN et al., 2008).

Além disso, estudos imuno-citoquímicos para verificar a localização da anexina A5, mostram claramente uma distribuição específica da proteína entre as células endócrinas estudadas, sugerindo que a A5 pode contribuir para o processo de secreção (KAWAMINAMI et at., 1998).

O aumento da síntese de A5 nas glândulas de veneno reserpinizadas, sugere que está ocorrendo uma regulação negativa da A5 pela estimulação da inervação noredrenérgica, sugerindo que essa inervação está modulando o processo de secreção.

As mitocôndrias são responsáveis pela produção de mais de $90 \%$ da energia na forma de ATP utilizada pelas células dos eucariotos. Nas glândulas de veneno a síntese da proteína ATP-sintase mitocondrial-símile foi regulada negativamente pela inervação noradrenérgica, parecendo não contribuir com o funcionamento da mitocôndria. No entanto, em células acinares da parótida, uma grande quantidade de mitocôndrias está localizada na região perinuclear e as mitocôndrias podem estar regulando uma variedade de funções nucleares facilitando uma efetiva secreção em células acinares da parótida (BRUCE et al., 2004)

Com relação às toxinas identificadas, mostramos pela primeira vez que a inervação noradrenérgica está regulando a síntese das toxinas como as lectinas tipo C, $\mathrm{PLA}_{2}$ e Bj46a. A respeito da classe das lectinas tipo $\mathrm{C}$, quando analisadas separadamente, notamos que as CTL-símile GPIb-BP e o fator de coagulação IX/X estão presentes apenas nas glândulas de veneno reserpinizadas. Estes dados são similares aos obtidos em glândulas de veneno quiescentes, sugerindo que a inervação noradrenérgica pode estar atuando na regulação da síntese e produção destas proteínas, ou ainda pode estar promovendo a exocitose dessas toxinas já presentes no estado quiescente da glândula. A inervação noradrenérgica também está regulando 
positivamente a síntese de SVMP-PI e negativamente a síntese de SVMP-PII. Estes dados mostram claramente que estas toxinas estão sendo reguladas pela inervação noradrenérgica. Provavelmente, a síntese de outras toxinas é regulada por outros neurotransmissores.

\subsection{Síntese de proteínas da glândula acessória durante o ciclo de produção de veneno}

A glândula acessória é uma estrutura pouco conhecida e estudada apesar de pertencer ao aparelho glandular de veneno. As secreções liberadas por esta região não sabe se pode modificar o veneno formado. Sabe-se que a luz da glândula principal de veneno conecta-se ao ducto primário e este forma uma alça e passa no interior da glândula acessória (KOCHVA; GANS, 1966).

O estudo morfológico realizado da glândula acessória da Bothrops jararaca mostrou que esta glândula possui uma exocitose tardia, 4 dias após a extração de veneno do tipo apócrina. Devido à secreção tardia, foi demonstrado que a secreção da glândula acessória não participa da formação do veneno total da serpente Bothrops jararaca (SAKAI; CARNEIRO; YAMANOUYE, 2012).

A identificação das proteínas presentes nesta glândula assim como identificação das proteínas nas quais as sínteses são reguladas durante o ciclo de produção e secreção acrescenta novas informações a esta estrutura pouco conhecida. Mostramos pela primeira vez a presença de toxinas do veneno como Lectinas tipo C, SVSP, SVMP, $\mathrm{PLA}_{2}$, LAAO, PLI, Bj46a, precursor de pEKW, GC, PN e disintegrinas e que estas toxinas assim, como na glândula de veneno tem sua síntese regulada durante o ciclo de produção de veneno. Além disso, as proteínas HSP90, a Histona H2 e a DPPIV tiveram sua síntese regulada durante o ciclo de produção de veneno.

As proteínas Heat shock (HSPs) são expressas ou estão aumentadas nas células em resposta a vários estímulos biológicos. As HSPs são conhecidas como chaperonas auxiliando na conformação correta das proteínas, durante a síntese, transporte e degradação das proteínas. Em glândulas parótidas a HSP90 provavelmente esta envolvida na síntese e transporte de proteínas (VANMUYLDER et al., 2000). HPS90 é capaz de associar-se direta ou indiretamente com microtúbulos e microfilamentos, portanto, também participa da reorganização do citoesqueleto (CZAR et al., 1996; MATSUBARA et al., 1990). Nas glândulas acessórias foi demonstrado que no $4^{\circ}$ dia 
após a extração de veneno, as células mucosas apresentam uma exocitose maciça, com rompimento da membrana apical, semelhante a uma secreção apócrina, com isso parte do conteúdo citoplasmático é perdido. No $7^{\circ}$ dia após a extração de veneno uma regeneração das células já está ocorrendo (SAKAI; CARNEIRO; YAMANOUYE, 2012). Provavelmente a redução na síntese das proteínas HSP90 e DPPIV após a extração de veneno estão relacionadas com essa perda de conteúdo citoplasmático. Além disso, o aumento da síntese de histona H2 na glândula acessória 7 dias após a extração de veneno, sugere seu envolvimento no reestabelecimento da célula, regulando a transcrição e síntese de proteínas, consequentemente regulando a produção e secreção desta glândula.

Um estudo morfológico da glândula acessória realizado durante o ciclo de secreção mostrou que a secreção da glândula acessória ocorre 1 horas após a extração de veneno, sugerindo que a secreção desta glândula pouco contribui para o veneno total (SAKAI; CARNEIRO; YAMANOUYE, 2012). No entanto, nossos dados interessantemente mostraram a presença de diversas toxinas do veneno em todos os estágios da glândula acessória avaliados. Além disso, identificamos a presença de dois tipos de inibidores de metaloproteinases na glândula acessória, Bj46a e o precursor do tri-peptídeo inibidor piroglutamato-lisina-triptofano (pEKW). Em glândulas acessórias, o Bj46a assim como na glândula de veneno teve sua síntese aumentada após a extração de veneno, já o pEKW foi encontrado apenas nas glândulas acessórias e apenas nas glândulas que não sofreram extração de veneno.

O tri-peptídeo inibidor pEKW está presente em concentrações milimolares $(4,5$ $\mathrm{mM}$ ) no veneno de diversas serpentes, como por exemplo a serpente Bothrops asper, e também na própria Bothrops jararaca (FRANCIS; KAISER, 1993; MARQUESPORTO et al., 2008) atua inibindo a atividade das metaloproteinases. Além disso, estudos demonstraram que a perda deste tri-peptídeo deixa o veneno muito mais tóxico (MACKESSY; WILLIAMS; ASHTON, 2003). Os tri-peptídeos inibidores juntamente com outros mecanismos como as altas concentrações de hidrolases, tais como o baixo $\mathrm{pH}$ do veneno e a alta concentração do íon citrato na glândula inibem as enzimas do veneno, estabilizando e inibindo a autólise das proteínas (MUNEKIYO; MACKESSY, 2005). Os resultados obtidos na identificação das proteínas da glândula acessória nos leva a pensar que a secreção desta glândula pode estar auxiliando a proteger a integridade da glândula de veneno, uma vez que esta glândula estoca veneno no seu lumen por longos períodos, ou seja, o aumento da síntese e secreção de inibidores 
enzimáticos estaria protegendo a serpente contra um potencial dano causado pelos próprios componentes do veneno. É interessante notar que a secreção da glândula no $4^{\circ}$ dia após a extração de veneno coincide com o início da secreção do veneno recémsintetizado.

\subsection{Considerações finais}

O estudo proteômico da glândula principal de veneno, bem como da acessória mostrou que em todos os estágios estudados as toxinas estão presentes nessas glândulas e que após a extração de veneno ocorre uma síntese não sincronizada de toxinas, bem como a síntese de proteínas importantes para o processo de síntese e secreção. Interessante ressaltar que inibidores de fosfolipases $A_{2}$ e de metaloproteinases foram detectados nessas glândulas, sendo que maior quantidade nas glândulas acessória.

Em relação aos mecanismos que controlam a síntese e secreção de veneno, estes são regulados parcialmente pela inervação noradregérgica, que está atuando tanto na síntese de proteínas estruturais importantes para o processo de síntese e secreção, bem como promovendo exocitose das toxinas presentes na glândula de veneno no estado quiescente.

Apesar dos estudos morfológicos sugerirem que a secreção da glândula acessória não participa do veneno total devido a exocitose tardia (SAKAI et al., 2012), o estudo proteômico mostra que essa glândula produz toxinas e inibidores de fosfolipases e metaloproteinases, sugerindo que a secreção dessa glândula, apesar de ocorrer mais tardiamente, 4 dias após a extração veneno, deve participar sim do veneno total, bem como proteger a glândula dos efeitos tóxicos do veneno.

A maioria dos estudos de biologia molecular e de transcriptoma utilizam somente a glândula principal de veneno de 3 a 4 dias após a extração de veneno, devido ao pico de atividade sintética das células secretoras (CARNEIRO et al., 1991; DE LUCCA et al., 1974; KOCHVA, 1987; KOCHVA, 1978). Neste trabalho mostramos que a síntese de toxinas tanto na glândula principal de veneno como na acessória ocorre de maneira não sincronizada, portanto os estudos realizados anteriormente podem ter perdido informações importantes sobre a diversidade de toxinas, além do fato de não incluirem a glândula acessória. Os dados obtidos neste trabalho fornecem informações inéditas trazendo novos conhecimentos sobre os mecanismos celulares envolvidos no 
desencadeamento da síntese e secreção de veneno e podem contribuir de forma significativa para o estudo das toxinas de suas diversidades. 
6 CONCLUSÕES 
Os resultados desta tese mostraram que:

1. A análise proteômica das glândulas de veneno da serpente Bothrops jararaca revelou perfis distintos entre os estágios quiescentes e ativados, ou ainda após os tratamentos com reserpina e agonistas de adrenoceptores alfa e beta;

2. Proteínas citoplasmáticas e do retículo endoplasmático estão sendo reguladas durante o ciclo de produção de veneno;

3. Grande parte das toxinas está presente no estágio quiescente da glândula de veneno e algumas toxinas estão presentes exclusivamente neste estágio, no entanto outras são mais abundantes nos estágios ativados da glândula de veneno, mostrando que a síntese de toxinas ocorre de maneira não sincronizada;

4. A estimulação da inervação noradrenérgica regula a síntese de proteínas citoplasmáticas e mitocondriais, além da síntese de algumas toxinas;

5. A estimulação da inervação noradrenérgica, através da ativação dos adrenoceptores $\alpha$ e $\beta$, pode promover a exocitose de toxinas já sintetizadas presentes no lumen da glândula de veneno, bem como promover a síntese de novas toxinas;

6. Na glândula acessória, após a extração de veneno, a síntese de algumas proteínas envolvidas na produção e secreção, bem como de toxinas foi regulada;

7. Diversas toxinas foram identificadas na glândula acessória, assim como a presença de inibidores endógenos de metaloproteinases e de fosfolipases $\mathrm{A}_{2}$ foram detectadas;

8. A produção e secreção das toxinas da glândula acessória também ocorrem de maneira não sincronizada.

Em conclusão, os dados obtidos nessa tese demonstram que durante a ativação da glândula de veneno várias proteínas envolvidas no processo de síntese e secreção de proteínas estão sendo reguladas. Além disso, mostramos pela primeira vez a presença de várias toxinas no estado dito como quiescente e que a síntese de toxinas ocorre de maneira não sincronizada. A estimulação da inervação noradrenérgica é importante para modular a síntese de proteinas envolvidas no processo de síntese e secreção, bem como de algumas toxinas.

A glândula acessória, apesar de ter uma exocitose tardia, é capaz de sintetizar e secretar toxinas, bem como inibidores de metaloproteinases e fosfolipase $\mathrm{A}_{2}$ que podem estar agindo protegendo a glândula de veneno de seus efeitos tóxicos. Proteínas da 
glândula acessória também tiveram sua síntese regulada nos diferentes tempos estudados e parecem estar envolvidas no restabelecimento celular devido a perda de conteudo citoplasmático após a secreção apócrina que ocorre nessa glândula. 
REFERÊNCIAS 


\section{REFERENCIAS $^{4}$}

AMSTERDAM, A.; OHAD, I.; SHRAMM, M. M. Dynamic changes in the ultrastructure of acinar of the rat parotid gland during the secretory cycle. J. Cell Biol., v. 41, n. 3, p. 753-773, 1969.

ARAÚJO, F. A. A.; SANTALÚCIA, M.; CABRAL, F. R. Epidemiologia dos accidentes por animais peçonhentos. In: CARDOSO, J. L. R.; FRANÇA, F. O. S.; WEN, F. H.; MÁLAQUE, C. M. S.; HADDAS JR, V. (Ed.). Animais peçonhentos no Brasil: biología, clínica e terapéutica dos accidentes. São Paulo: Savier, FAPESP, 2003. p. 6-12.

BARKA, T. $\beta$-adrenergic affects on salivary glands: growth and gene regulation. Acta Histochem. Cytochem., v. 23, p. 245-255, 1990.

BASTOS, C. M. V. Análise da expressão génica diferencial das glândulas de veneno de Bothrops jararaca (Serpentes: Viperidae). 2011. 157 f. Tese (Doutorado em Ciências Biológicas) - Instituto de Ciências Biomédicas, Universidade de São Paulo, São Paulo, 2011.

BAUM, B. J. Principles of saliva secretion. Ann. N.Y. Acad. Sci., v. 694, p. 17-23, 1993.

BAUM, B. J. Regulation of salivary secretion. In: SCREEBNY, L. M. (Ed.). The salivary system. Boca Raton, FL: CRC Press Inc, 1987. p. 123-134.

BAUM, B. J.; WELLNER, R. B. Neural mechanisms of salivary gland and secretion: receptors in salivary glands. In: GARRET, J. R.; EKSTRÖM, J.; ANDERSON, L. C. (Ed.). Front oral biology. Basel: Karger, 1999. v. 11, p. 44-58.

BDOLAH, A. The venom glands of snakes and venom secretion. In: LEE, C. Y. (Ed.). Snake Venom. Berlin: Springer Verlag, 1979. v. 52. p. 41-57.

BEATON, A.; WILKINS, R. J.; WHEELER, T. Lactation-associated and prolactinresponsive changes in protein synthesis in mouse mammary cells. Tissue and Cell, v. 29, n. 5, p. 509-516, 1997.

BELLOUMINI, H .E. Extraction and quantities of venom obtained from some Brazilian snakes. In: BUHERL, W.; BUCKLEY, V.; DEULOFEU, V. (Ed.). Venomous animals and their venoms. New York: Academic Press; 1968. p. 97-117.

BEN-SHAUL, Y.; LIFSHITZ, S. H.; KOCHVA, E. Ultrastructural aspects of secretion in the venom glands of Vipera palaestinae. In: DE VRIES, A.; KOCHVA, E. (Ed.). Toxins of animal of plants origen. London: Gordon and Breach, 1971. p. 87-107.

\footnotetext{
${ }^{4}$ De acordo com:

ASSOCIAÇÃO BRASILEIRA DE NORMAS TÉCNICAS. NBR 6023: informação e documentação: referências: elaboração. Rio de Janeiro, 2002.
} 
BRADFORD M. A rapid and sensitive method for the quantification of microgram quantities of protein utilizing the principle of protein-dye binding. Anal Biochem., v. 72, p. 248-254, 1976.

BRASIL. Ministério da Saúde. Guia de vigilância epidemiológica. 7. ed. Brasília, DF, 2009. 816 p. (Série A. Normas e Manuais Técnicos).

BRASIL. Ministério da Saúde. Manual de diagnostico e tratamento dos acidentes por animais peçonhetos. Brasília, DF: Fundação Nacional de Saúde, 1998. 131 p.

BRENO, M. C.; YAMANOUYE, N.; PREZOTO, B. C.; LAZARI, M. F. M.; TOFFOLETTO, O.; PICARELLI, Z. P. Maintenance of the snake Bothrops jararaca (Wied, 1824) in captivity. The Snake, v. 22, p. 126-130, 1990.

BROSKY, M. E. The role of saliva in oral health: strategies for prevention and management of xerostomia. J. Support. Oncol., v. 5, p. 215-225, 2007.

BROWN, R. S.; BROWN, M. B.; BDOLAH, A.; KOCHVA, E. Accumulation of some secretory enzymes in venom glands of V. palaestinae. Am. J. Physiol., v. 229, n. 6, p. 1675$1679,1975$.

BRUCE, J. I. E.; GIOVANNUCCI, D. R.; BLINDER, G.; SHUTTLEWORTH, T. J.; YULE, D. I. Modulation of $\left[\mathrm{Ca}^{2+}\right]$ i signaling dynamics and metabolism by perinuclear mitochondria in mouse parotid acinar cells. J. Biol. Chem., v. 279, n. 13, p. 12909-12917, 2004.

BUSCH, L.; STERIN-BORDA, L.; BORDA, E. Differences in the regulatory mechanism of amylase release by rat parotid and submandibular glands. Arch. Oral Biol., v. 47, n. 10, p. 717-722, 2002.

BYLUND, D. B.; EIKENBERG, D. C.; HIEBLE, J. P.; LANGER, S. Z.; LEFKOWITZ, R. J.; MINNEMAN, K. P.; MOLINOFF, P. B.; RUFFOLO, R. R. JR.; TRENDELENBURG, U. International Union of Pharmacology nomenclature of adrenoceptors. Pharmacol. Rev., v. 46, n. 2, p. 121-126, 1994.

BYLUND, D. B.; RAY-PRENGER, C.; MURPHY, T. J. Alpha-2A and alpha-2B adrenergic receptor subtypes: antagonist binding in tissue and cell lines containing only one subtype. $\mathbf{J}$. Pharmacol. Exp. Ther., v. 245, n. 2, p. 600-607, 1988.

CARNEIRO, S. M.; ASSAKURA, M. T.; BARRENCE, F. A. C.; CARDOSO, S. R. T.; CAMARGO, A. C. M.; SESSO, A. Immunolocalization of venom metaloproteases in venom glands of adult and of newborn snakes of Bothrops jararaca. Tissue Cell., v. 34, n. 6, p. 381389, 2002.

CARNEIRO, S. M.; FERNANDES, W.; DELlA CASA, M. S.; SESSO, A. Cytochemical analysis of acid phosphatase activity in the venom secretory cells of Bothrops jararaca. Tissue Cell., v. 33, n. 4, p. 311-317, 2001.

CARNEIRO, S. M.; PINTO, V. R.; JARED, C.; LULA, L. A.; FARIA, F. P.; SESSO, A. Morphometric studies on venom secretory cells from Bothrops jararacussu (Jararacuçu) before and after venom extraction. Toxicon, v. 29, n. 6, p. 569-580, 1991. 
CHIPPAUX J. P.; WILLIAMS, V.; WHITE, J. Snake venom variability: methods of study, results and interpretation. Toxicon, v. 29, n. 11, p. 1279-12303, 1991.

CIDADE, D. A. P.; SIMÃO, T. A.; DÁVILA, A. M. R.; WAGNER, G.; JUNQUEIRA-DE AZEVEDO, I. L. M.; HO, P. L.; BON, C.; ZINGALI, R. B.; ALBANO, R. M. Bothrops jararaca venom gland transcriptome: Analysis of the gene expression pattern. Toxicon, v. 48, p. 437-461, 2006.

COGLI, L.; PROGIDA, C.; BRAMATO, R.; BUCCI, C. Vimentin phosphorylation and assembly are regulated by the small GTPase. BBA Mol. Cell Biol., v. 1833, n. 6, p. 12831293, 2013.

COOPER, J. A. Actin dynamics: Tropomyosin provides stability. Curr. Biol., v. 12, p. R523R525, 2002.

CURRIER, R. B.; CALVETE, J. J.; SANZ, L.; HARRISON, R. A.; ROWLEY, P. D.; WAGSTAFF, S. C. Unusual stability of messenger RNA in snake venom reveals gene expression dynamics of venom replenishment. Plos One, v. 7, n. 8, p. 1-10, 2012.

CZAR, M. J.; WELSH, M. J.; PRATT, W. B. Immunofluorescence localization of the 90-kDa heat-shock protein cytoskeleton. Eur. J. Cell Biol., v. 70, n. 4, p. 322-330, 1996.

DANIELS, T. E.; WU, A. J. Xerostomia - Clinical evaluation and treatment in general practice. J. Calif. Dent. Assoc., v. 28, p. 933-941, 2000.

DE LUCCA, F. L.; HADDAD, A.; KOCHVA, E.; ROTHSCHILD, A. M.; VALERI, V. Protein synthesis and morphological changes in the secretory epithelium of the venom gland of Crotalus durissus terrificus at different times after manual extraction of venom. Toxicon, v. 12, n. 4, p. 361-368, 1974.

DORNER, A. J.; WASLEY, L. C.; RANEY, P.; HAUGEJORDEN, S.; GREEN, M.; KAUFAMAN, R. J. The stress response in Chinese hamster ovary cells. Regulation of ERp72 and protein disulfide isomerase expression and secretion. J. Biol. Chem., v. 265, n. 35, p. 22029-22034, 1990.

EKSTROM, J. Neuropeptides and secretion. J. Dent. Rev., v. 66, p. 524-530, 1987.

EKSTROM, J.; EKMAN, R.; HAKASON, R.; LUTS, A.; SUNDLER, F.; TOBIN, G. Effects of capsaicin pretreatment on neuropeptides and salivary secretion of rat parotid glands. Br. J. Pharmacol., v. 97, p. 1031-1038, 1988.

FENWICK, A. M.; GUTBERLET JR, R. L.; EVANS, J. A.; PARKINSON, C. L. Morphological and molecular evidence for phylogeny and classification of South American pitvipers, genera Bothrops, Bothriopsis, and Bothrocophias (Serpentes: Viperidae). Zool. J. Linnean Society, v. 156, p. 617-640, 2009.

FOX, J. W.; SERRANO, S. M. T. Insights into and speculations about snake venom metalloproteinase (SVMP) synthesis, folding and disulfide bond formation and their contribution to venom complexity. FEBS J., v. 275, n. 12, p. 3016-3030, 2008. 
FRANCIS, B.; KAISER, I. I. Inhibition of metalloproteinases in Bothrops asper venom by endogenous peptides. Toxicon. v. 31, n. 7, p. 889-899, 1993.

FRANCO, F. L. Origem e diversidade das serpentes. In: CARDOSO, J. L. R.; FRANÇA, F. O. S.; WEN, F. H.; MÁLAQUE, C. M. S.; HADDAS JR, V. (Ed.). Animais peçonhentos no Brasil: biologia, clínica e terapêutica dos acidentes. São Paulo: Sarvier, 2003. p. 13-32.

GARRETT, J. R. The proper role of nerves in salivary secretion - a review. J. Dent. Res., v. 66, p. 387-397, 1987.

GARRETT, J. R.; THULIN, A. Changes in parotid acinar cells accompanying salivary secretion in rats on sympathetic or parasympathetic nerve stimulation. Cell Tissue Res., v. 159, p. 179-193, 1975.

GENDEREN, H. O.; KENIS, H.; HOFSTRA, L.; NARULA, J.; REUTELINGSPERGER, C. P. M. Extracellular annexin A5: Functions of phosphatidylserine-binding and two dimensional crystallization. Biochim. Biophys. Acta. v. 1783, p. 953-963, 2008.

GOMES, N.; POURTO, G. Atlas anatômico de Bothrops jararaca Wied, 1824 (Serpentes: Viperidae). Mem. Inst. Butantan, v. 55, p. 69-100, 1993.

GONÇALVES, L. R.; YAMANOUYE, N.; NUÑEZ-BURGOS, G. B.; FURTADO, M. F.; BRITTO, L. R.; NICOLAU, J. Detection of calcium-binding proteins in venom and Duvernoy's glands of South American snakes and their secretions. Comp. Biochem. Physiol. C Pharmacol. Toxicol. Endocrinol., v. 118, n. 2, p. 207-211, 1997.

GRAHAM, R. M.; PEREZ, D. M.; HWA, J.; PIASCIK, M. T. Alpha 1-adrenergic receptor subtypes. Molecular structure, function and signaling. Circ. Res., v. 78, n. 5, p. 737-749, 1996.

IVASKA, J.; PALLARI, H. M.; NEEVO, J.; ERIKSSON, J. E. Novel functions of vimentin in cell adhesion, migration, and signaling. Exp. Cell Res., v. 313, n. 10, p. 2050-2062, 2007.

JAMIESON, J. D.; PALADE, G. E. Intracellular transport of secretory proteins in the pancreatic exocrine cell I. Role of the peripheral elements of the Golgi complex. J. Cell Biol., 34, n. 2, p. 577-596, 1967a.

JAMIESON, J. D.; PALADE, G. E. Intracellular transport of secretory proteins in the pancreatic exocrine cell II. Transport to condensing vacuoles and zymogen granules. J. Cell Biol., v. 34, n. 2, p. 597-615, 1967 b.

JIANG, L.; HE, L.; FOUNTOULAKIS, M. Comparison of protein precipitation methods for sample preparation prior to proteomics analysis. J. Chroma., v. 1023, n. 2, p. 317-320, 2004.

JUNQUEIRA-DE-AZEVEDO, I. L; HO, P. L. A survey of gene expression. And diversity in the venom glands of the pitiviper snake Bothrops insularis through the generation of expressed sequence tags (ESTs). Gene, v. 299, n. 1-2, p. 279-291, 2002.

KARDONG, K. V. The evolution of snakes apparatus in snakes from colubrids to viperids \& elapids. Mem. Inst. Butantan, v. 46, p. 105-118, 1982. 
KASTURIRATNE, A.; WICKREMASINGHE, A. R.; SILVA, N.; GUNAWARDENA, N. K.; PATHMESWARAN, A.; PREMARATNA, R.; SAVIOLI, L.; LALLOO, D. G.; SILVA, H. J. The global burden of snakebite: A literature analysis and modelling based on regional estimates of envenoming and deaths. PLoS Medicine, v. 5, n. 11, p. 1591-1604, 2008.

KAWAMINAMI, M. YAMAGUCHI, K.; MIYAGAWA, S.; NUMAZAWA, S. IOKA, H.; KURUSU, S. HASHIMOTO, I. Ovariectomy enhances the expression and nuclear translocation of annexin 5 in rat anterior pituitary gonadothophs. Mol. Cell Endocrinol., v. 141, n. 1-2, p. 73-78, 1998.

KERCHOVE, C. M.; CARNEIRO, S. M.; MARKUS, R. P.; YAMANOUYE, N. Stimulation of the $\alpha$-adrenoceptor triggers the venom production cycle in the venom gland of Bothrops jararaca. J. Exp. Biol., v. 207, n. 3, p. 411-416, 2004.

KERCHOVE, C. M.; LUNA, M. S.; ZABLITH, M. B.; LAZARI, M. F.; SMAILI, S. S.; YAMANOUYE, N. Alpha1-adrenoceptors trigger the snake venom production cycle in secretory cells by activating phosphatidylinositol 4,5-bisphosphate hydrolysis and ERK signaling pathway. Comp. Biochem. Physiol. A, v. 150, p. 431-437, 2008.

KITANO, H. Systems biology: a brief overview. Science, v. 295, n. 5560, p. 1662-1664, 2002.

KLEIN, R. M. Development, structure and function of the salivary glands. In: AVERY, J. K. Oral development and history. Stuttgart: Thieme, 2002. p. 321-330.

KOCHVA E. A quantitative study of venom secretion by Vipera palaestinae. Am. J. Trop. Med. Hyg., v. 9, p. 381-390, 1960.

KOCHVA E. The origin of snakes and evolution of the venom apparatus. Toxicon, v. 25, n. 1, p. 65-106, 1987.

KOCHVA E.; GANS, C. The structure of the venom gland and secretion of venom in viperid snakes. In: REWELL, F. E.; RUSSELL, P. R. Animal toxins. Oxford: Pergamon Press, 1967. p. $195-203$.

KOCHVA, E. Oral glands of the Reptilia. In: GANS, C. (Ed.). Biology of the reptilia. London: Academic Press, 1978. v. 8b. p. 43-161.

KOCHVA, E.; GANS, C. Histology and histochemistry of venom glands of some crotaline snakes. Copeia, v. 3, p. 506-515, 1966.

KOCHVA, E.; GANS, C. Salivary glands of snakes. Clin. Toxicol., v. 3, n. 3, p. 363-387, 1970.

KONGO, H.; HIRONO, C.; SUGITA, M.; IWASA, Y.; SHIBA, Y. Involvement of cytoskeletal integrity of the regulation of $\mathrm{Cl}^{-}$and amylase secretion from rat parotid acinar cells. Biom. Res., v. 29, n. 3, p. 131-139, 2008. 
KRIEGENBURG, F.; POULSEN, E. G.; KOCH, A.; KRÜGER, E.; HARTMANN, P. Redox control of the ubiquitin-proteasome system: from molecular mechanisms to functional significance. Antioxid. Redox Signal., v. 15, n. 8, p. 2265-2299, 2011.

LAEMMLI, U. K. Cleavage of structural proteins during the assembly of the heat of bacteriophage T4. Nature, v. 227, n. 5259, p. 680-685, 1970.

LAWSON, R.; SLOWINSKI, J. B.; CROTHER, B .I.; BURBRINK, F. T. Phylogeny of the Colubroidea (Serpentes): new evidence from mitochondrial and nuclear genes. Mol. Phylogenet. Evol., v. 37, n. 2, p. 581-601, 2005.

LEES, J. G.; BACH, C. T. T.; O NEILL, G. M. Interior decoration. Tropomyosin in actin dynamics and cell migration. Cell Adh. Migr., v. 5, n. 2, p. 181-186, 2011.

LI, Y. M.; ZHANG, Y.; XIANG, B.; ZHANG, Y. Y.; WU, L. L.; YU, G. Y. Expression and functional analysis of $\beta$-adrenoceptor subtypes in rabbit submandibular gland. Life Sci., v. 79, p. 2091-2098, 2006.

LUNA, M. S. A.; HORTENCIO, T. M. A.; FERREIRA, S. Z.; YAMANOUYE, N. Sympathetic outflow activates the venom of the snake Bothrops jararaca by regulating the activation of transcription factors and the synthesis of the venom gland proteins. J. Exp. Biol., v. 212, n. 10, p. 1535-1543, 2009.

MAATTANEN, P.; GEHRING, K.; BERGERON, J. J.; THOMAS, D. Y. Protein quality control in the ER: the recognition misfolded protein. Semin. Cell Dev. Biol., v. 21, n. 5, p. 500-511, 2010.

MACKESSY, S. P. Morphology and ultrastructure of the venom gland of the Northen pacific rattlesnake Crotalus viridis oreganus. J. Mophol., v. 208, p. 109-128, 1991.

MACKESSY, S. P.; WILLIAMS, K.; ASHTON, K. Characterization of the venom of the midget faded rattlesnake (Crotalus viridis concolor): a case of venom paedomorphosis? Copeia, v. 4, p. 769-782, 2003.

MACKESSY, S. P; BAXTER, L. M. Bioweapons synthesis and storage: The venom gland of front-fanged snakes. Zoologischer Anzeiger, v. 245, p. 147-159, 2006.

MARCHI, F.; HADDAD, A.; DE LUCCA, F. L. Radioautographic and biochemical studies of secretion of venom protein in the South American rattlesnake Crotalus durissusterrificus. J. Exp. Zool., v. 203, n. 3, p. 429-442, 1978.

MARQUES, O. A. V.; SAZIMA, I. História natural dos répteis da Estação Ecológica JuréiaItatins, In: MARQUES, O. A. V.; DULEBA, W. (Ed.). Estação Ecológica Juréia-Itatins. Ambiente físico, flora e fauna. São Paulo: Holos, 2004. p. 212-236.

MARQUES-PORTO, R.; LEBRUN, I.; PIMENTA, D. C. Self-proteolysis regulationin the Bothrops jararaca venom: The metallopeptidases and their intrinsic peptide inhibitor. Comp. Biochem. Psysiol. C, v. 147, p. 424-433, 2008. 
MARTINEZ, J. R.; ADSHEAD, P. C.; QUISSELL, D. O.; BARBERO, G. J. The chronically reserpinized rats as a possible model for cystic fibrosis. I. Submaxillary gland morphology and ultrastructure. Pediatr. Res., v. 9, p. 463-469, 1975a.

MARTINEZ, J. R.; ADSHEAD, P. C.; QUISSELL, D. O.; BARBERO, G. J. The chronically reserpinized rats as a possible model for cystic fibrosis. II. Comparison and cilioinhibitory effects of submaxillary saliva. Pediatr. Res., v. 9, p. 470-475, 1975 b.

MARTINEZ-OLIVARES, R.; VILLANUEVA, I.; RACOTTA, R.; PIÑON, M. Depletion and recovery of catecholamines in several organs of rats treated with reserpine. Auton. Neurosci. Basic Clin., v. 128, n. 1-2, p. 64-69, 2006.

MATSUBARA, O.; KASUGA, T.; MARUMO, F.; ITOH, H; TASHIMA, Y. Localization of 90-kDa heat shock protein in the kidney. Kidney Int., v. 38, n. 5, p. 830-834, 1990.

MATYSKIELA, M. E.; MARTIN, A. Design principles of a universal protein degradation machine. J. Mol. Biol., v. 425, n. 2, p. 199-213, 2013.

MELGAREJO, A. R. Serpentes peçonhentas do Brasil. In: Animais peçonhentos no Brasil: biologia, clínica e terapêutica dos acidentes. São Paulo: Sarvier, 2003. p. 33-61.

MOTOYAMA, A.; YATES, J. R. Multidimensional LC separations in shotgun proteomics. Anal. Chem., v. 80, n. 19, p.7187-7193, 2008.

MUNEKIYO, S. M.; MACKESSY, S. P. Presence of peptide inhibitors in rattlesnake venoms and their effects on endogenous metaloproteases. Toxicon, v. 45, p. 255-263, 2005.

MUNRO, S.; PELHAM, H. R. B. An Hsp70ike protein in the ER: identity with the $78 \mathrm{kd}$ glucose-regulated protein and immunoglobulin heavy chain binding protein. Cell, v. 46, n. 2, p. 291-300, 1986.

NASHIDA, T.; YOSHIE, S.; IMAI, A.; SHIMOMURA, H. Presence of cytoskeleton proteins in parotid glands and their roles during secretion. Arch. Oral Biol., v. 49, n. 2, p. 975-982, 2004.

NESATYY, V. J.; SUTER, M. J. F. Analysis of environmental stress response on the proteome level. Mass Spec. Rev., v. 27, n. 20, p. 556-574, 2008.

NEVES-FERREIRA, A. G. C.; VALENTE, R. H.; PERALES, J.; DOMONT, G. B. In: MACKESSY S. P. (Ed.). Reptile venoms and toxins. New York: Taylor and Francis; CRC Press, 2009. p. 259-284.

ODELL, G. V.; FERRY, E. C.; VICK, L. M.; FENTON, A. W.; DECKER, L. S.; COWELL, R. L.; OWNBY, C. L.; GUTIERREZ, J. M. Citrate inhibition of snake venom proteases. Toxicon, v. 36, n. 12, p. 1801-1806, 1998.

OOKUMA, S.; FUKUDA, M.; NISHIDA, E. Identification of a DAF-16 transcriptional target gene, scl-1, that regulates longevity and stress resistance in Caenorhabditis elegans. Curr. Biol., v. 13, n. 3, p. 427-431, 2003. 
ORON, U.; BDOLAH, A. Regulation of protein synthesis in venom gland of viperid snakes. J. Cell Biol., v.56, p. 1771-1790, 1973.

ORON, U.; KINAMON, S.; BDOLAH, A. Asynchrony in the synthesis of secretory proteins in the venom gland of the snake Vipera palaestinae. Biochem. J., v. 174, n. 3, p. 733-739, 1978.

OSTLUND, R. E. JR.; LEUNG, J. T.; KIPNIS, D. N. Myosins of secretory tissues. J. Cell. Biol., v. 73, n. 3, p. 827-836, 1978.

PANDEY, A.; MANN, M. Proteomics to study genes and genomes. Nature, v. 405, n. 6788, p. 837-846, 2000.

PASSMORE, L. A.; SCHMEING, T. M.; MAAG, D.; APPLEFIELD, D. J.; ACKER, M. G.; ALGIRE, M. A.; LORSCH, J. R.; RAMAKRISHNAN, V. The eukaryotic translation initiation factors elF1 and elF1A induce an open conformation of the $40 \mathrm{~S}$ ribosome. Mol. Cell., v. 26, n. 1, p. 41-50, 2007.

PELUSO, G.; DE SANTIS, M.; INZITARI, R.; FINALI, C.; CABRAS, T.; MESSANA, I.; CASTAGNOLA, M.; FERRACCIOLI, G. F. Proteomic study of salivar peptides and proteins in patients with Sjögren's syndrome before and after pilocarpine treatment. Arthritis and Rheum., v. 56, n. 7, p. 2216-2222, 2007.

PERRIN, D.; MOLLER, K.; HANKE, K.; SOLING, H.D. cAMP and $\mathrm{Ca}^{2+}$-mediated secretion in parotid acinar cells is associated with reversible changes in the organization of the cytoskeleton. J. Cell Biol., v. 116, n. 1, p. 127-134, 1992.

PORAT-SHLIOM, N.; MILBERG, O.; MASEDUNSKAS, A.; WEIGERT, R. Multiple roles for the actin cytoskeleton during regulated exocytosis. Cell. Mol. Life Sci., v. 70, n. 12, 2012.

PROCTOR, G. B.; CARPENTER, G. H. Regulation of salivary gland fucntion by autonomic nerves. Auton. Neurosci., v. 133, n. 1, p. 3-18, 2007.

PYRON, R.A. et al., The phylogeny of advanced snakes (Colubroidea), with discovery of a new subfamily and comparison of support methods for likelihood trees. Mol. Phylogenet. Evol.,, v. 58, p. 329-342, 2011.

QUISSEL, D. O.; BARZEN, K. A. Secretory response of dispersed rat submandibular cells. II. Mucin secretion. Am. J. Physiol., v. 238, n. 3, p. C99-C106, 1980.

QUISSELL, D. O.; BARZEN, K. A.; DEISHER, L. M. Rat submandibular and parotid protein phosphorylation and exocytosis: Effect of site-selective cAMP analogs. Crit. Rev. Oral Biol. Med., v. 4, p. 443-448, 1993.

QUISSELL, D. O.; WATSON, E.; DOWD, F. J. Signal transduction mechanisms involved in salivary gland regulated exocytosis. Crit. Rev. Oral Biol. Med., v. 3, n. 1-2, p. 83-107, 1992.

RAMAZANOVA, A. S.; STARKOV, V. G.; OSIPOV, A. V.; ZIGANSHIN, R. H.; FILKIN, S. Y.; TSETLIN, V. I.; UTKIN, Y. N. Cysteine-rich venom proteins from the snakes of 
Viperinae subfamily - molecular cloning and phylogenetic relationship. Toxicon, v. 53, p. 162-168, 2008.

ROTENBERG, D.; BAMBERGER, E. S.; KOCHVA, E. Studies on ribonucleic acid synthesis in the venom glands ofVipera palaestinae (Ophidia, Reptilia). Biochem. J., v. 121, n. 4, 609-612, 1971.

SAKAI, F. Glândula acessória e ducto primário de serpente Bothrops jararaca durante o ciclo de produção de veneno: Um estudo morfológico. 2011. 76 p. Dissertação (Mestrado em Biologia Celular e Tecidual) - Instituto de Ciências Biomédicas, Universidade de São Paulo, São Paulo, 2011.

SAKAI, F.; CARNEIRO, S. M.; YAMANOUYE, N. Morphological study of accessory gland of Bothrops jararaca and its secretory cycle. Toxicon, v. 59, n. 3, p. 393-401, 2012.

SALOMÃO, M.G. Estrutura e secreção das glândulas de Duvernoy de Sibynomorphus mikani (Colubridae, Dipsadinae) e das glândulas de veneno de Bothrops jararaca (Viperidae, Crotalinae) e Micrurus frontalis (elapidae, Elapinae) e a influência dos estados de alimentação e jejum. 1991. 122 f. Tese (Doutorado em Zoologia) - Instituto de Biociências, Universidade de São Paulo, São Paulo, 1991.

SAZIMA, I. Estudo da biologia comportamental da jararaca, Bothrops jararaca, com uso de marcas naturais. Mem. Inst. Butantan, v. 50, p. 83-99, 1988.

SCHAEFFER, R. C. Jr.; BERNICK, S.; ROSENQUIST, H.; RUSSELL, F. E. The histochemistry of the venom glands of the rattlesnake Crotalus viridis helleri - I Lipid and non-specific esterase. Toxicon, v. 10, n. 2, p. 183-186, 1972a.

SCHAEFFER, R. C. Jr.; BERNICK, S.; ROSENQUIST, H.; RUSSELL, F. E. The histochemistry of the venom glands of the rattlesnake Crotalus viridis helleri - II Monoamine oxidade, acid and alkaline phosphatase. Toxicon, v. 10, n. 2, p. 295-297, 1972 b.

SCHNEYER, L. H.; YOUNG, J. A.; SCHNEYER, C. A. Salivary secretions of electrolytes. Physiol. Rev., v. 52, p. 720-777, 1972.

SCHREIBER, M. C.; KARLO, J. C.; KOVALICK, G. E. A novel cDNA from Drosophila encoding a protein with similarity to mammalian cysteine-rich secretory proteins, wasp venom antigen5, and plant group 1 pathogenesis-related proteins. Gene, v. 191, n. 2, p. 135$141,1997$.

SEGAWA, A.; RIVA, A.; LOFFREDO, F.; CONGIU, T.; YAMASHIMA, S.; TESTA RIVA, F. Cytoskeletal regulation of human salivary secretion studied by high resolution electron microscopy and confocal laser microscopy. Eur. J. Morphol., v. 36, p. 41-45, 1998.

SERRANO, S. M.; MATOS, M. F. C.; MANDELBAUM, F. R.; SAMPAIO, C. A. M. Basic proteinases from Bothrops moojeni (caissaca) venom-I. Isolation and activity of two proteinases, MSP1 and MSP2, on synthetic substrates and on platelet aggregation. Toxicon, v. 31, n. 4, p. 471-481, 1993. 
SERRANO, S. M. T.; SHANNON, J. D.; WANG, D.; CAMARGO, A. C. M.; FOX, J. W. A multifaceted analysis of viperid snake venoms by two-dimensional gel electrophoresis: An approach to understanding venom protoemics. Proteomics, v. 5, n. 2, p. 501-510, 2005.

SOUSA, J.; MONTEIRO, R. Q.; CASTRO, H. C.; ZINGALI, R. B.; P. Proteolytic action of Bothrops jararaca venom upon its own constituents. Toxicon, v. 39, p. 787-792, 2001.

SOUZA, W. Doenças negligenciadas. In: Ciência e tecnologia para o desenvolvimento nacional: estudos estratégicos. Rio de Janeiro: Academia Brasileira de Ciências, 2010. p. 56.

TASHIMA, A. K.; ZELANIS, A.; KITANO, E. S.; LANZER, D.; MELO, R. L.; RIOLI, V.; SANT'ANNA, S. S.; SCHENBERG, A. C.; CAMARGO, A. C.; SERRANO, S. M. Peptidomics of three Bothrops snakes venoms: insights into the molecular diversification of proteomes and peptidomes. Mol. Cell Proteomics, v. 11, n. 11, p. 1245-1262, 2012.

TOWBIN, H.; STAEHELIN, T.; GORDON, J. Eletrophoretic transfer of proteis from polyacrylamide gels to nitrocelulose sheets: procedure and some application. Proc. Natl. Acad. Sci. USA., v. 76, p. 4350-4354, 1979.

VALENTE, R. H.; DRAGULEV, B.; PERALES, J.; FOX, J. W.; DOMONT, G. B. Cloning and characterization of $\mathrm{Bj} 46 \mathrm{a}$, a snake venom metalloproteinase inhibitor from Bothrops jararaca serum. Eur. J. Biochem., v. 268, n. 10, p. 3042-3052, 2001.

VALENTE, R. H.; NEVES-FERREIRA, A .G. C.; CAFFARENA, E. R.; DOMONT, G. B.; PERALES, J. In: LIMA M. E.; PIMENTA, A. M. C.; MARTIN-EAUCLAIRE, M. F.; ZINGALI, R.; ROCHAT, H. (Eds). Animal Toxins: State of the Art. Perspectives on Health and Biotechnology. Belo Horizonte: UFMG, 2009. p. 547-558.

VANDENPLAS, M. L.; VANDENPLAS, S.; BREBNER, K.; BESTER, A .J.; BOYD, C. D. Characterization of the messenger RNA population coding for components of viperid snake venom. Toxicon, v. 23, n. 2, p. 289-305, 1985.

VANMUYLDER, N.; EVRARD, L.; DAELEMANS, P.; DOUROV, N. Chaperones in the parotid gland: Localization of heat shock proteins in humans adult salivary glands. Cells Tiss. Organs, v. 167, p. 199-205, 2000.

VARMA, D. R.; DENG, X. F. Cardiovascular alpha 1-adrenoceptors subtypes: function and signaling. Can. J. Physiol. Pharmacol., v. 78, n. 4, p. 267-292, 2000.

VIDAL, N. HEDGES, S. B. The molecular evolutionary tree of lizards, snakes, and amphisbaenians. C. R. Biologies, v. 332, n. 2-3, p. 129-139, 2009.

VILJOEN, C. C.; BOTES, D. P. Influence $\mathrm{pH}$ on the kinetic and spectral propertis of phospholipase $\mathrm{A}_{2}$ from Bitis gabonica (Gaboon adder) snake venom. Toxicon, v. 17, p. 7787, 1979.

VON BÜLTZINGSLÖWEN, I.; SOLLECITO, T. P.; FOX, P. C.; DANIELS, T.; JONSSON, R.; LOCKHART, P. B.; WRAY, D. BRENNAN, M. T.; CARROZZO, M.; GANDERA, B.; FUJIBAYASHI, T.; NAVAZESH, M.; RHODUS, N. L.; SCHIODT, M. Salivary 
dysfunction associated with systemic diseases: systematic review and clinical management recommendations. Oral Surg. Oral Med. Oral Pathol. Oral Radiol. Endod., v. 103, n. S57, p. e1-15, 2007.

WAGSTAFF, S. C.; FAVREAU, P.; CHENEVAL, O.; LAING, G. D.; WILKINSON, M. C.; MILLER, R. L.; STÖCKLIN, R.; HARRISON, R. A. Molecular characterization of endogenous snake venom metalloproteinase inhibitors. Bioch. Biophys. Res. Commun., v. 365, n. 4, p. 650-656, 2008.

WANG, X.; PATTISON, J. S.; SU, H. Posttranslational modifications and quality control. Circ. Res., v. 112, p. 367-381, 2013.

WARSHAWSKY, H.; HADDAD, A.; GONÇALVES, R. P.; VALERI, V.; DE LUCCA, F. L. Fine structure of the venom gland epithelium of the South American rattlesnake and radioautographic studies of protein formation by secretory cells. Am. J. Anat., v. 138, p. 79120, 1973.

WATSON, E.; DOWD, F.; JACOBSONS, K.; HORWITZS, H. Reserpinization: Effects on parotid gland function. J. Dent. Res., v. 63, n. 2, p. 82-86, 1984.

WETTESTEIN, G.; BELLAYE, P. S.; MICHEAU, O.; BONNIAUD, P. H. Small heat shock proteins and the cytoskeleton: An essential interplay for cell integrity? Intern. J. Biochem. Cell Biol., v. 44, p. 1680-1686, 2012.

WRIGTH, L. L.; LUEBKE, J. L. Somatostatin-, vasoactive intestinal polyptide- and neuropeptide Y-like immunoreactivity in eye-and submandibular gland-projecting sympathetic neurons. Brain Res., v. 494, n. 2, p. 267-275, 1989.

WU, C.; PARROTT, A.M.; FU, C.; LIU, T.; MARINO, S.M.; GLADYSHEV, V.N.; JAIN, M.R.; BAYKAL, A.T.; LI, Q.; OKA, S.; SADOSHIMA, J.; BEUVE, A.; SIMMONS, W.J.; LI, H. Thioredoxin 1-mediated post-translational modifications: reduction, transnitrosylation, denitrosylation, and related proteomics methodologies. Antioxid. Redox Signal, v. 15, n. 9, p. 2565-2604, 2011.

WU, Q.; YUAN, H.; ZHANG, L.; ZHANG, Y. Recent advances on multidimensional liquid chromatography-mass spectrometry for proteomics: From qualitative to quantitative analysis - A review. Analytica Chimica Acta, v. 731, p. 1-10, 2012.

XIAO, D.; BUCHHOLZ, J. N.; ZHANG, L. Pregnancy attenuates uterine artery pressuredependent vascular tone: role of PKC/ERK pathway. Am. J. Physiol. Heart Circ. Physiol., v. 290, n. 6, p. H2337-H2343, 2006.

YAMANOUYE, N.; BRITTO, L. R. G.; CARNEIRO, S. M.; MARKUS, R. P. Control of venom production and secretion by sympathetic outflow in the snake Bothrops jararaca. $\mathbf{J}$. Exp. Biol., v. 200, n. 19, p. 2547-2556, 1997.

YAMANOUYE, N.; CARNEIRO, S. M.; SCRIVANO, C. N.; MARKUS, R. P. Characterization of $\beta$-adrenoceptors responsible for venom production in the venom gland of the snake (Bothrops jararaca). Life Sci., v. 67, n. 3, p. 217-226, 2000. 
YAMAZAKI, Y.; MORITA, T. Structure and function of snake venom cysteine-rich secretory proteins. Toxicon, v. 44, n. 3, p. 227-231, 2004.

YEH, C. K.; GHOSH, P. M.; DANG, H.; LIU, Q.; LIN, A. L.; ZHANG, B. X.; KATZ, M. S. Beta-adrenergic-responsive activation of extracellular signal-regulated protein kinases in salivary cells: role of epidermal growth factor receptor and cAMP. Am. J. Physiol. Cell Physiol., v. 288, n. 6, p. c1357-1366, 2005.

YEH, C. K.; CHANDRASEKAR, B.; LIN, A. L.; DANG, H.; KAMAT, A.; ZHU, B.; KATZ, M. S. Cellular signals underlying $\beta$-adrenergic receptor mediated salivary gland enlargement. Differentiation, v. 83, n. 1, p. 68-76, 2012.

ZABLITH, M. B. Vias de sinalização desencadeadas pela estimulação do adrenoceptor $\beta$ em células secretoras da glândula de veneno da serpente Bothrops jararaca. $2007.78 \mathrm{f}$. Dissertação (Mestrado em Biologia Celular e Tecidual) - Instituto de Ciências Biomédicas, Universidade de São Paulo, São Paulo, 2007.

ZAGO, D. A. Estudo morfológico e histoquimico de glândulas salivares relacionadas com a evolução da função venenosa nos ofídios. 1971. 69 f. Tese (Doutorado em Histologia) Instituto de Ciências Biomédicas, Universidade de São Paulo, São Paulo, 1971.

ZELANIS, A.; TASHIMA, A. K.; PINTO, A. F.; LEME, A.F.; STUGINSKI, D. R.; FURTADO, M. F.; SHERMAN, N. E.; HO, P. L.; FOX, J. W.; SERRANO, S. M. Bothrops jararaca venom proteome rearrangement upon neonate to adult transition. Proteomics, v. 11, n. 21, p. 4218-4242, 2011. 
APÊNDICE A 
APÊNDICE A- Proteínas identificadas dos spots específicos de gel 2-DE das glândulas de veneno da serpente Bothrops jararaca no estágio quiescente.

\begin{tabular}{|c|c|c|c|c|c|c|c|c|}
\hline $\begin{array}{c}\mathbf{N}^{\circ} \text { Spot } \\
\text { 0 dia }\end{array}$ & Proteína & $\begin{array}{l}\text { Número } \\
\text { acesso }\end{array}$ & $\begin{array}{l}\text { Proteína } \\
-10 \lg P\end{array}$ & $\begin{array}{c}\text { Cobertura } \\
\%\end{array}$ & Peptídeo & Organismo & Localização celular & Processo biológico \\
\hline $1 *$ & Similar to GRP94 & 149637905 & 382.14 & 5 & 4 & Ornithorhynchus anatinus & Retículo endoplasmático & Protein folding, Anti-apoptosis \\
\hline \multirow[t]{2}{*}{$2 *$} & $78 \mathrm{kDa}$ glucose regulated protein & 47085775 & 95.87 & 13 & 6 & Danio rerio & Retículo endoplasmático & ER overload response \\
\hline & HSP70 & 63146078 & 104.86 & 14 & 7 & Oxyuranus scutellatus & Citoplasma & Stress response \\
\hline 3\# & Ecto-5'-nucleotidase & 211926756 & 77.68 & 9 & 4 & Gloydius b. brevicaudus & Membrana & Nucleotide catabolic process \\
\hline $4 *$ & HSP70 & 63146078 & 104.86 & 14 & 7 & Oxyuranus scutellatus & Citoplasma & Stress response \\
\hline \multirow[t]{2}{*}{$5^{*}$} & $78 \mathrm{kDa}$ glucose regulated protein & 47085775 & 95.87 & 13 & 6 & Danio rerio & Retículo endoplasmático & ER overload response \\
\hline & HSP70 & 63146078 & 104.86 & 14 & 7 & Oxyuranus scutellatus & Citoplasma & Stress response \\
\hline $6^{*}$ & Calreticulin & 44969651 & 1539.71 & 8 & 5 & Gallus gallus & Retículo endoplasmático & Protein folding \\
\hline $7 *$ & Calreticulin & 387014936 & 79.96 & & & Crotalus admanteus & Retículo endoplasmático & Protein folding \\
\hline \multirow[t]{2}{*}{$8^{*}$} & Putative calreticulin variant 2 & 197129213 & 582.99 & 10 & 2 & Taeniopygia guttata & Retículo endoplasmático & Protein folding \\
\hline & $\begin{array}{l}\text { Zinc metalloproteinase- } \\
\text { disintegrin BITM06A }\end{array}$ & 82214993 & 122.22 & 21 & 12 & Bothrops insularis & Secretada - PIII & Proteolysis \\
\hline \multirow[t]{2}{*}{ 9* } & $\begin{array}{c}\text { Chain A, The three dimensional } \\
\text { structure of Bothropasin }\end{array}$ & 253722676 & 1045.59 & 7 & 2 & Bothrops jararaca & Secretada - PIII & Cell adhesion \\
\hline & Protein disulfide isomerase & 63146076 & 892.07 & 6 & 2 & Oxyuranus scutellatus & Retículo endoplasmático & $\begin{array}{l}\text { Homeostasis, Metabolic and } \\
\text { apoptotic process }\end{array}$ \\
\hline $10^{*}$ & L-amino-acid oxidase & 195927838 & 3233.06 & 15 & 8 & Bothropoides pauloensis & Secretada - LAAO & Apoptosis, Cytolysis, Hemolysis \\
\hline \multirow[t]{3}{*}{$11 \#$} & Protein disulfide isomerase A6 & 327261299 & 150.07 & 46 & 7 & Anolis carolinensis & Retículo endoplasmático & $\begin{array}{c}\text { Homeostasis, Metabolic and } \\
\text { apoptotic process }\end{array}$ \\
\hline & $\begin{array}{l}\text { Glutaminyl-peptide } \\
\text { cyclotrasferase }\end{array}$ & 82121485 & 79.60 & 18 & 4 & Bothrops jararaca & Secretada & Proteolysis \\
\hline & HSP70 & 63146078 & 113.32 & 10 & 6 & Oxyuranus scutellatus & Citoplasma & Stress response \\
\hline
\end{tabular}


APÊNDICE A- Proteínas identificadas dos spots específicos de gel 2-DE das glândulas de veneno da serpente Bothrops jararaca no estágio quiescente.

\begin{tabular}{|c|c|c|c|c|c|c|c|c|}
\hline $\begin{array}{c}\mathbf{N}^{\circ} \text { Spot } \\
\text { 0 dia }\end{array}$ & Proteína & $\begin{array}{l}\text { Número } \\
\text { acesso }\end{array}$ & $\begin{array}{c}\text { Proteína } \\
-10 \lg P\end{array}$ & $\begin{array}{c}\text { Cobertura } \\
\%\end{array}$ & Peptídeo & Organismo & Localização celular & Processo biológico \\
\hline $12^{*}$ & L-amino acid oxidase & 347602324 & 74.93 & 10 & 5 & Bothropoides pauloensis & Secretada - LAAO & Apoptosis, Cytolysis, Hemolysis \\
\hline \multirow[t]{2}{*}{ 13\# } & Protein disulfide isomerase A6 & 327261299 & 162.90 & 43 & 8 & Anolis carolinensis & Retículo endoplasmático & $\begin{array}{c}\text { Homeostasis, Metabolic and } \\
\text { apoptotic process }\end{array}$ \\
\hline & $\begin{array}{l}\text { ATP synthase subunit beta, } \\
\text { mitochondrial-like }\end{array}$ & 327264485 & 112.53 & 19 & 4 & Meleagris gallopavo & Mitocôndria & ATP synthesis, Transport \\
\hline \multirow[t]{3}{*}{ 14\# } & Protein disulfide isomerase A6 & 327261299 & 173.59 & 51 & 11 & Anolis carolinensis & Retículo endoplasmático & $\begin{array}{c}\text { Homeostasis, Metabolic and } \\
\text { apoptotic process }\end{array}$ \\
\hline & $\begin{array}{l}\text { Zinc metalloproteinase- } \\
\text { disintegrin }\end{array}$ & 82197476 & 121.35 & 14 & 7 & Bothrops insularis & Secretada - PII & Cell adhesion \\
\hline & $\begin{array}{l}\text { ATP synthase subunit beta, } \\
\text { mitochondrial-like }\end{array}$ & 327264485 & 102.71 & 19 & 4 & Meleagris gallopavo & Mitocôndria & ATP synthesis, Transport \\
\hline \multirow[t]{3}{*}{ 15\# } & Protein disulfide isomerase A6 & 327261299 & 150.07 & 46 & 7 & Anolis carolinensis & Retículo endoplasmático & $\begin{array}{l}\text { Homeostasis, Metabolic and } \\
\text { apoptotic process }\end{array}$ \\
\hline & $\begin{array}{l}\text { Glutaminyl-peptide } \\
\text { cyclotrasferase }\end{array}$ & 82121485 & 79.60 & 18 & 4 & Bothrops jararaca & Secretada - GC & Proteolysis \\
\hline & HSP70 & 63146078 & 113.32 & 10 & 6 & Oxyuranus scutellatus & Citoplasma & Stress response \\
\hline \multirow[t]{3}{*}{ 16\# } & Zinc metalloproteinase disintegrin & 82214993 & 112.33 & 24 & 9 & Bothrops insularis & Secretada - PIII & Proteolysis \\
\hline & BITM06A & & & & & & & \\
\hline & $\begin{array}{l}\text { Precursor Protein disulfide } \\
\text { isomerase A3-precursor }\end{array}$ & 387017522 & 279.09 & 26 & 5 & Crotalus adamanteus & Retículo endoplasmático & $\begin{array}{c}\text { Homeostasis, Metabolic and } \\
\text { apoptotic process }\end{array}$ \\
\hline \multirow[t]{2}{*}{ 17\# } & $\begin{array}{c}\text { Chain A, The three dimensional } \\
\text { structure of Bothropasin }\end{array}$ & 253722676 & 511.33 & 6 & 2 & Bothrops jararaca & Secretada - PIII & Cell adhesion \\
\hline & $\begin{array}{l}\text { Precursor Protein disulfide } \\
\text { isomerase A3-precursor }\end{array}$ & 387017522 & 304.29 & 33 & 6 & Crotalus adamanteus & Retículo endoplasmático & $\begin{array}{c}\text { Homeostasis, Metabolic and } \\
\text { apoptotic process }\end{array}$ \\
\hline 18\# & $\begin{array}{c}\text { Precursor Protein disulfide } \\
\text { isomerase A3-precursor }\end{array}$ & 387017522 & 335.26 & 33 & 7 & Crotalus adamanteus & Retículo endoplasmático & $\begin{array}{c}\text { Homeostasis, Metabolic and } \\
\text { apoptotic process }\end{array}$ \\
\hline
\end{tabular}


APÊNDICE A- Proteínas identificadas dos spots específicos de gel 2-DE das glândulas de veneno da serpente Bothrops jararaca no estágio quiescente.

\begin{tabular}{|c|c|c|c|c|c|c|c|c|}
\hline $\begin{array}{c}\mathrm{N}^{\circ} \text { Spot } \\
\text { 0 dia }\end{array}$ & Proteína & $\begin{array}{l}\text { Número } \\
\text { acesso }\end{array}$ & $\begin{array}{c}\text { Proteína } \\
\text {-10lgP }\end{array}$ & $\begin{array}{c}\text { Cobertura } \\
\%\end{array}$ & Peptídeo & Organismo & Localização celular & Processo biológico \\
\hline & $\begin{array}{c}\text { Chain B, The three dimensional } \\
\text { structure of Bothropasin }\end{array}$ & 209870468 & 55.15 & 4 & 1 & Bothrops jararaca & Secretada - PIII & Proteolysis \\
\hline \multirow[t]{2}{*}{ 19\# } & $\begin{array}{c}\text { Vascular Apoptosis-Inducing } \\
\text { Protein- } 1\end{array}$ & 82220669 & 60.90 & 6 & 2 & Crotalus atrox & Secretada - PIII & Apoptosis \\
\hline & $\begin{array}{l}\text { ATP Synthase subunit alpha, } \\
\text { mitochondrial-like }\end{array}$ & 327259463 & 100.99 & 18 & 5 & Meleagris gallopavo & Mitocôndria & ATP synthesis, Transport \\
\hline 20\# & $\begin{array}{l}\text { Zinc metalloprotease-disintegrin } \\
\text { halysase }\end{array}$ & 82211845 & 126.83 & 11 & 8 & Gloydius halys & Secretada - PIII & Apoptosis \\
\hline $21^{*}$ & $\begin{array}{c}\text { Vascular Apoptosis-Inducing } \\
\text { Protein- } 1\end{array}$ & 82220669 & 60.90 & 6 & 2 & Crotalus atrox & Secretada - PIII & Apoptosis, Cell adhesion \\
\hline $22 *$ & Beta actin & 52078486 & 1031.62 & 19 & 3 & Oxyuranus scutellatus & Citoplasma & Structural element, organization \\
\hline 23* & $\begin{array}{c}\text { Beta actin } \\
\text { Actin, alpha skeletal muscle }\end{array}$ & $\begin{array}{c}296434064 \\
67462115\end{array}$ & $\begin{array}{l}154.95 \\
181.97\end{array}$ & $\begin{array}{l}20 \\
16\end{array}$ & $\begin{array}{l}4 \\
5\end{array}$ & $\begin{array}{c}\text { Gloydius brevicaudus } \\
\text { Atractaspis microlepidota }\end{array}$ & $\begin{array}{l}\text { Citoplasma } \\
\text { Citoplasma }\end{array}$ & $\begin{array}{c}\text { Structural element, organization } \\
\text { Skeletal muscle fiber } \\
\text { development }\end{array}$ \\
\hline $24 *$ & $\begin{array}{c}\text { Beta-actin } \\
\text { Actin, alpha skeletal muscle }\end{array}$ & $\begin{array}{l}52078486 \\
67462115\end{array}$ & $\begin{array}{l}1015.64 \\
1015.64\end{array}$ & $\begin{array}{l}19 \\
9\end{array}$ & $\begin{array}{l}3 \\
3\end{array}$ & $\begin{array}{l}\text { Oxyuranus scutellatus } \\
\text { Atractaspis microlepidota }\end{array}$ & $\begin{array}{l}\text { Citoplasma } \\
\text { Citoplasma }\end{array}$ & $\begin{array}{l}\text { Structural element, organization } \\
\text { Skeletal muscle fiber } \\
\text { development }\end{array}$ \\
\hline 25\# & $\begin{array}{c}\text { Venom serine protease BthaT } \\
\text { Thrombin-like enzyme } \\
\text { bothrombin }\end{array}$ & $\begin{array}{l}82173559 \\
14285806\end{array}$ & $\begin{array}{l}83.07 \\
92.65\end{array}$ & $\begin{array}{l}14 \\
16\end{array}$ & $\begin{array}{l}3 \\
4\end{array}$ & $\begin{array}{l}\text { Bothrops alternatus } \\
\text { Bothrops jararaca }\end{array}$ & $\begin{array}{l}\text { Secretada - SVSP ácido } \\
\text { Secretada - SVSP ácido }\end{array}$ & $\begin{array}{l}\text { Proteolysis } \\
\text { Proteolysis }\end{array}$ \\
\hline 26\# & $\begin{array}{c}\text { Venom Serine protease BthaTL } \\
\text { Thrombin-like enzyme } \\
\text { bothrombin }\end{array}$ & $\begin{array}{l}82173559 \\
14285806\end{array}$ & $\begin{array}{l}816.65 \\
121.02\end{array}$ & $\begin{array}{l}12 \\
45\end{array}$ & $\begin{array}{c}3 \\
11\end{array}$ & $\begin{array}{l}\text { Bothrops alternatus } \\
\text { Bothrops jararaca }\end{array}$ & $\begin{array}{l}\text { Secretada - SVSP ácido } \\
\text { Secretada - SVSP ácido }\end{array}$ & $\begin{array}{l}\text { Proteolysis } \\
\text { Proteolysis }\end{array}$ \\
\hline \multirow[t]{2}{*}{ 27\# } & $\begin{array}{c}\text { Thrombin-like enzyme } \\
\text { bothrombin }\end{array}$ & 14285806 & 65.44 & 16 & 4 & Bothrops jararaca & Secretada - SVSP ácido & Proteolysis \\
\hline & Venom Serine protease BthaTL & 82173559 & 849.41 & 6 & 2 & Bothrops alternatus & Secretada - SVSP ácido & Proteolysis \\
\hline
\end{tabular}


APÊNDICE A- Proteínas identificadas dos spots específicos de gel 2-DE das glândulas de veneno da serpente Bothrops jararaca no estágio quiescente.

\begin{tabular}{|c|c|c|c|c|c|c|c|c|}
\hline $\begin{array}{c}\mathbf{N}^{\circ} \text { Spot } \\
\text { 0 dia }\end{array}$ & Proteína & $\begin{array}{l}\text { Número } \\
\text { acesso }\end{array}$ & $\begin{array}{l}\text { Proteína } \\
-10 \lg P\end{array}$ & $\begin{array}{c}\text { Cobertura } \\
\%\end{array}$ & Peptídeo & Organismo & Localização celular & Processo biológico \\
\hline \multirow[t]{2}{*}{$28 *$} & Venom serine proteinase HS112 & 82233396 & 892.07 & 13 & 2 & Bothrops jararaca & Secretada - SVSP neutro & Proteolysis \\
\hline & Venom Serine protease BthaTL & 82173559 & 535.32 & 6 & 2 & Bothrops alternatus & Secretada - SVSP neutro & Proteolysis \\
\hline \multirow[t]{2}{*}{$29 *$} & $\begin{array}{c}\text { Thrombin-like enzyme } \\
\text { bothrombin }\end{array}$ & 14285806 & 61.00 & 13 & 3 & Bothrops jararaca & Secretada - SVSP neutro & Proteolysis \\
\hline & Serine proteinase BITS01A & 82244284 & 77.30 & 7 & 2 & Bothrops insularis & Secretada - SVSP neutro & Proteolysis \\
\hline $30 *$ & Venom serine proteinase HS114 & 82233395 & 1108.63 & 19 & 4 & Bothrops jararaca & Secretada - SVSP neutro & Proteolysis \\
\hline \multirow[t]{2}{*}{ 31\# } & Thrombin-like enzyme & 123883734 & 93.69 & 18 & 6 & Lachesis stenophrys & Secretada - SVSP neutro & Proteolysis \\
\hline & Venom serine proteinase HS112 & 82233396 & 892.07 & 13 & 2 & Bothrops jararaca & Secretada - SVSP neutro & Proteolysis \\
\hline $32 *$ & Annexin A2-like isoform 1 & 327284494 & 89.76 & 18 & 5 & Anolis carolinensis & Secretada & Fibrinolysis \\
\hline \multirow[t]{3}{*}{ 33* } & Annexin A2-like isoform 1 & 327284494 & 89.76 & 18 & 5 & Anolis carolinensis & Secretada & Fibrinolysis \\
\hline & Venom serine proteinase HS112 & 82233396 & 73.20 & 35 & 7 & Bothrops jararaca & Secretada - SVSP básico & Proteolysis \\
\hline & $\begin{array}{c}\text { Thrombin-like enzyme } \\
\text { bothrombin }\end{array}$ & 14285806 & 61.03 & 32 & 4 & Bothrops jararaca & Secretada - SVSP básico & Proteolysis \\
\hline $34 *$ & Annexin A2-like isoform 1 & 327284494 & 89.76 & 18 & 5 & Anolis carolinensis & Secretada & Fibrinolysis \\
\hline \multirow[t]{2}{*}{ 35\# } & C-type lectin BiL & 82126834 & 61.67 & 32 & 4 & Bothrops insularis & Secretada - CTL & Hemagglutinating activity \\
\hline & Bothroinsularin subunit alpha & 229621684 & 117.25 & 61 & 8 & Bothrops insularis & Secretada - CTL & $\begin{array}{c}\text { Blood coagulation cascade } \\
\text { inhibiting }\end{array}$ \\
\hline $36^{*}$ & Venom serine protease homolog & 82240434 & 100.37 & 24 & 6 & Bothrops jararacussu & Secretada - SVSP básico & Proteolysis \\
\hline $37 *$ & Venom serine protease homolog & 82240434 & 88.80 & 24 & 6 & Bothrops jararacussu & Secretada - SVSP básico & Proteolysis \\
\hline \multirow[t]{2}{*}{ 38\# } & Venom serine protease homolog & 82240434 & 81.24 & 19 & 6 & Bothrops jararacussu & Secretada - SVSP ácido & Proteolysis \\
\hline & $\begin{array}{l}\text { Venom plasminogen activator } \\
\qquad \text { LV-PA }\end{array}$ & 123891732 & 104.18 & 24 & 10 & Lachesis muta muta & Secretada - SVSP ácido & Regulation of blood pressure \\
\hline \multirow[t]{2}{*}{ 39\# } & Venom serine protease homolog & 82240434 & 81.24 & 19 & 6 & Bothrops jararacussu & Secretada - SVSP ácido & Proteolysis \\
\hline & $\begin{array}{l}\text { Tropomyosin beta chain isoform } \\
\qquad 1 \text {, partial }\end{array}$ & 380793471 & 131.53 & 40 & 14 & Macaca mulatta & Citoplasma & Muscle contraction \\
\hline $40 *$ & Venom serine proteinase HS114 & 82233395 & 1611.23 & 19 & 4 & Bothrops jararaca & Secretada - SVSP ácido & Proteolysis \\
\hline
\end{tabular}


APÊNDICE A- Proteínas identificadas dos spots específicos de gel 2-DE das glândulas de veneno da serpente Bothrops jararaca no estágio quiescente.

\begin{tabular}{|c|c|c|c|c|c|c|c|c|}
\hline $\begin{array}{c}\mathbf{N}^{\circ} \text { Spot } \\
\text { 0 dia }\end{array}$ & Proteína & $\begin{array}{l}\text { Número } \\
\text { acesso }\end{array}$ & $\begin{array}{c}\text { Proteína } \\
-10 \lg P\end{array}$ & $\begin{array}{c}\text { Cobertura } \\
\%\end{array}$ & Peptídeo & Organismo & Localização celular & Processo biológico \\
\hline $41^{*}$ & Venom serine proteinase HS114 & 82233395 & 1119.79 & 19 & 4 & Bothrops jararaca & Secretada - SVSP ácido & Proteolysis \\
\hline $42 *$ & $\begin{array}{l}\text { Venom serine protease BthaTL } \\
\text { Thrombin-like enzyme } \\
\text { bothrombin }\end{array}$ & $\begin{array}{l}82173559 \\
14285806\end{array}$ & $\begin{array}{l}164.20 \\
104.97\end{array}$ & $\begin{array}{l}49 \\
32\end{array}$ & $\begin{array}{c}27 \\
9\end{array}$ & $\begin{array}{l}\text { Bothrops alternatus } \\
\text { Bothrops jararaca }\end{array}$ & $\begin{array}{l}\text { Secretada - SVSP ácido } \\
\text { Secretada - SVSP ácido }\end{array}$ & $\begin{array}{l}\text { Proteolysis } \\
\text { Proteolysis }\end{array}$ \\
\hline $43 *$ & $\begin{array}{l}\text { Cysteine-rich seceretory protein } \\
\qquad \text { Ch-CRPIb }\end{array}$ & 190195315 & 67.78 & 18 & 3 & Crotalus horridus & Secretada - CRISP & - \\
\hline $44^{*}$ & $\begin{array}{l}\text { Cysteine-rich seceretory protein } \\
\qquad \text { Ch-CRPIb }\end{array}$ & 190195315 & 67.78 & 18 & 3 & Crotalus horridus & Secretada - CRISP & - \\
\hline $45^{*}$ & 14-3-3 protein theta-like & 327261224 & 52.60 & 10 & 2 & Anolis carolinensis & Citoplasma & $\begin{array}{l}\text { Protein targeting, Signal } \\
\text { transduction }\end{array}$ \\
\hline $46^{*}$ & $\begin{array}{l}\text { Zinc metalloproteinase/disintegrin } \\
\text { contains: metalloproteinase } \\
\text { jararafibrase-2 }\end{array}$ & 82219563 & 1037.21 & 9 & 2 & Bothrops jararaca & Secretada - PII & Cell adhesion \\
\hline $47 *$ & Zinc metalloproteinase $\mathrm{BnP} 2$ & 172044592 & 48.22 & 32 & 2 & Bothropoides pauloensis & Secretada - PI & Apoptosis \\
\hline 48\# & Triosephosphate isomerase 1 & 90200404 & 61.02 & 17 & 3 & $\begin{array}{c}\text { Sus scrofa } \\
\text { Xiphophorus maculatus }\end{array}$ & Citoplasma & Gluconeogenesis, Glucolysis \\
\hline $49 *$ & $\begin{array}{c}\text { Glutathione S-transferase Mu 1- } \\
\text { like }\end{array}$ & 327270916 & 43.41 & 8 & 2 & Anolis carolinensis & Citoplasma & Gluthatione metabolic process \\
\hline 50\# & Venom serine protease homolog & 82240434 & 88.80 & 24 & 6 & Bothrops jararacussu & Secretada - SVSP ácido & Proteólises \\
\hline \multirow[t]{2}{*}{ 51\# } & $\begin{array}{c}\text { Nucleoside diphosphate kinase } \\
\text { Zinc metalloproteinase BITM02A }\end{array}$ & $\begin{array}{l}20376446 \\
82214994\end{array}$ & $\begin{array}{l}164.41 \\
107.22\end{array}$ & $\begin{array}{l}66 \\
19\end{array}$ & $\begin{array}{l}10 \\
6\end{array}$ & $\begin{array}{l}\text { Bothrops insularis } \\
\text { Bothrops insularis }\end{array}$ & $\begin{array}{l}\text { Citoplasma } \\
\text { Secretada - PI }\end{array}$ & $\begin{array}{c}\text { Nucleotide metabolism } \\
\text { Proteolysis }\end{array}$ \\
\hline & $\begin{array}{l}\text { Similar to tyrosine } 3 / \text { tryptophan } 5 \\
\text {-monooxygenase activation } \\
\text { protein, zeta polypeptide isoform } 5\end{array}$ & 73974186 & 96.63 & 32 & 5 & Canis lúpus familiaris & Mitocôndria & $\begin{array}{c}\text { Negative regulation of } \\
\text { transcription, Signal transduction }\end{array}$ \\
\hline 52\# & L-amino acid oxidase precursor & 347602324 & 138.12 & 15 & 9 & Bothropoides pauloensis & Secretada - LAAO & Apoptosis, Cytolysis, Hemolysis \\
\hline
\end{tabular}


APÊNDICE A- Proteínas identificadas dos spots específicos de gel 2-DE das glândulas de veneno da serpente Bothrops jararaca no estágio quiescente.

\begin{tabular}{|c|c|c|c|c|c|c|c|c|}
\hline $\begin{array}{c}\mathbf{N}^{\circ} \text { Spot } \\
\text { 0 dia }\end{array}$ & Proteína & $\begin{array}{l}\text { Número } \\
\text { acesso }\end{array}$ & $\begin{array}{l}\text { Proteína } \\
-10 \lg P\end{array}$ & $\begin{array}{c}\text { Cobertura } \\
\%\end{array}$ & Peptídeo & Organismo & Localização celular & Processo biológico \\
\hline & Cysteine rich secretory protein & 358801543 & 84.16 & 42 & 3 & Crolalus oreganus helleri & Secretada - CRISP & - \\
\hline $53 *$ & Phospholipase A2 2 & 292630844 & 261.88 & 18 & 3 & Bothrops asper & Secretada - PLA 2 & Inflamatory response \\
\hline $54 *$ & $\begin{array}{l}\text { Glycoprotein IB-binding protein } \\
\text { subunit } \alpha\end{array}$ & 82116886 & 94.82 & 35 & 5 & Bothrops jararaca & Secretada - CTL & $\begin{array}{l}\text { Hemostasis impairing toxin } \\
\text { Platelet aggregation inhibiting } \\
\text { toxin }\end{array}$ \\
\hline $55^{*}$ & $\begin{array}{l}\text { Glycoprotein IB-binding protein } \\
\text { subunit } \alpha\end{array}$ & 82116886 & 94.82 & 35 & 5 & Bothrops jararaca & Secretada - CTL & $\begin{array}{l}\text { Hemostasis impairing toxin, } \\
\text { Platelet aggregation inhibiting } \\
\text { toxin }\end{array}$ \\
\hline $56^{*}$ & $\begin{array}{l}\text { Glycoprotein IB-binding protein } \\
\text { subunit } \alpha\end{array}$ & 82116886 & 84.08 & 35 & 5 & Bothrops jararaca & Secretada - CTL & $\begin{array}{l}\text { Hemostasis impairing toxin } \\
\text { Platelet aggregation inhibiting } \\
\text { toxin }\end{array}$ \\
\hline $57 *$ & $\begin{array}{l}\text { Glycoprotein IB-binding protein } \\
\text { subunit } \alpha\end{array}$ & 82116886 & 84.08 & 35 & 5 & Bothrops jararaca & Secretada - CTL & $\begin{array}{l}\text { Hemostasis impairing toxin } \\
\text { Platelet aggregation inhibiting } \\
\text { toxin }\end{array}$ \\
\hline $58 *$ & $\begin{array}{c}\text { Glycoprotein IB-binding protein } \\
\text { subunit } \alpha\end{array}$ & 82116887 & 94.82 & 35 & 5 & Bothrops jararaca & Secretada - CTL & $\begin{array}{c}\text { Hemostasis impairing toxin } \\
\text { Platelet aggregation inhibiting } \\
\text { toxin }\end{array}$ \\
\hline $59 *$ & $\begin{array}{c}\text { Annexin A2 } \\
\text { Venom gland cyclophilin }\end{array}$ & $\begin{array}{c}168983833 \\
38374146\end{array}$ & $\begin{array}{l}731.52 \\
120.56\end{array}$ & $\begin{array}{l}18 \\
64\end{array}$ & $\begin{array}{c}3 \\
11\end{array}$ & $\begin{array}{l}\text { Mus musculus } \\
\text { Bitis gabonica }\end{array}$ & $\begin{array}{l}\text { Secretada } \\
\text { Citoplasma }\end{array}$ & Protein folding \\
\hline $60 \#$ & Venom gland cyclophilin & 38374146 & 212.95 & 9 & 2 & Bitis gabonica & Citoplasma & Protein folding \\
\hline 61\# & Phospholipase A2 2 & 158518414 & 146.95 & 72 & 10 & Bothrops insularis & Secretada - PLA 2 & Inflamatory response \\
\hline $62^{*}$ & $\begin{array}{l}\text { C-type lectin BiL } \\
\text { Bothroinsularin subunit alpha }\end{array}$ & $\begin{array}{c}82126834 \\
229621684\end{array}$ & $\begin{array}{l}2220.46 \\
1050.11\end{array}$ & $\begin{array}{l}34 \\
25\end{array}$ & $\begin{array}{l}7 \\
3\end{array}$ & $\begin{array}{l}\text { Bothrops insularis } \\
\text { Bothrops insularis }\end{array}$ & $\begin{array}{l}\text { Secretada - CTL } \\
\text { Secretada - CTL }\end{array}$ & $\begin{array}{c}\text { Hemagglutinating activity } \\
\text { Blood coagulation cascade } \\
\text { inhibiting }\end{array}$ \\
\hline $63^{*}$ & C-type lectin BiL & 82126834 & 61.67 & 32 & 4 & Bothrops insularis & Secretada - CTL & Hemagglutinating activity \\
\hline 64\# & Glycoprotein IB-binding protein & 82116883 & 76.61 & 35 & 5 & Bothrops jararaca & Secretada - CTL & Hemostasis impairing toxin \\
\hline
\end{tabular}


APÊNDICE A- Proteínas identificadas dos spots específicos de gel 2-DE das glândulas de veneno da serpente Bothrops jararaca no estágio quiescente.

\begin{tabular}{|c|c|c|c|c|c|c|c|c|}
\hline $\begin{array}{c}\mathrm{N}^{\circ} \text { Spot } \\
\text { 0 dia }\end{array}$ & Proteína & $\begin{array}{l}\text { Número } \\
\text { acesso }\end{array}$ & $\begin{array}{c}\text { Proteína } \\
-10 \lg P\end{array}$ & $\begin{array}{c}\text { Cobertura } \\
\%\end{array}$ & Peptídeo & Organismo & Localização celular & Processo biológico \\
\hline & subunit $\beta$ & & & & & & & $\begin{array}{l}\text { Platelet aggregation inhibiting } \\
\text { toxin }\end{array}$ \\
\hline & Disintegrin jarastatin & 123905785 & 99.32 & 58 & 8 & Bothrops jararaca & Secretada & $\begin{array}{c}\text { Apoptosis, cell adhesion, } \\
\text { chemotaxis }\end{array}$ \\
\hline \multirow[t]{2}{*}{ 65\# } & $\begin{array}{c}\text { Glycoprotein IB-binding protein } \\
\text { subunit } \beta\end{array}$ & 82116883 & 892.07 & 20 & 2 & Bothrops jararaca & Secretada - CTL & $\begin{array}{c}\text { Hemostasis impairing toxin } \\
\text { Platelet aggregation inhibiting } \\
\text { toxin }\end{array}$ \\
\hline & Bothroinsularin subunit beta & 229621685 & 57.20 & 22 & 2 & Bothrops insularis & Secretada - CTL & $\begin{array}{c}\text { Blood coagulation cascade } \\
\text { inhibiting }\end{array}$ \\
\hline $66^{*}$ & $\begin{array}{c}\text { Glycoprotein IB-binding protein } \\
\text { subunit } \beta\end{array}$ & 82116883 & 70.07 & 35 & 3 & Bothrops jararaca & Secretada - CTL & $\begin{array}{l}\text { Hemostasis impairing toxin } \\
\text { Platelet aggregation inhibiting } \\
\text { toxin }\end{array}$ \\
\hline $67 *$ & $\begin{array}{c}\text { Glycoprotein IB-binding protein } \\
\text { subunit } \beta\end{array}$ & 82116883 & 70.07 & 35 & 3 & Bothrops jararaca & Secretada - CTL & $\begin{array}{l}\text { Hemostasis impairing toxin } \\
\text { Platelet aggregation inhibiting } \\
\text { toxin }\end{array}$ \\
\hline $68 *$ & $\begin{array}{c}\text { Glycoprotein IB-binding protein } \\
\text { subunit } \beta\end{array}$ & 82116883 & 76.61 & 35 & 3 & Bothrops jararaca & Secretada - CTL & $\begin{array}{c}\text { Hemostasis impairing toxin } \\
\text { Platelet aggregation inhibiting } \\
\text { toxin }\end{array}$ \\
\hline $69 *$ & $\begin{array}{c}\text { Glycoprotein IB-binding protein } \\
\text { subunit } \beta\end{array}$ & 82116883 & 70.07 & 35 & 3 & Bothrops jararaca & Secretada - CTL & $\begin{array}{l}\text { Hemostasis impairing toxin } \\
\text { Platelet aggregation inhibiting } \\
\text { toxin }\end{array}$ \\
\hline \multirow[t]{2}{*}{ 70\# } & $\begin{array}{l}\text { Coagulation factor IX/factor X- } \\
\text { binding protein subunit B }\end{array}$ & 2851436 & 137.82 & 58 & 9 & Trimeresurus flavoviridis & Secretada - CTL & $\begin{array}{c}\text { Blood coagulation cascade } \\
\text { inhibiting toxin }\end{array}$ \\
\hline & $\begin{array}{c}\text { Glycoprotein IB-binding protein } \\
\text { subunit } \beta\end{array}$ & 82116883 & 121.92 & 61 & 3 & Bothrops jararaca & Secretada - CTL & $\begin{array}{l}\text { Hemostasis impairing toxin } \\
\text { Platelet aggregation inhibiting } \\
\text { toxin }\end{array}$ \\
\hline
\end{tabular}


APÊNDICE A- Proteínas identificadas dos spots específicos de gel 2-DE das glândulas de veneno da serpente Bothrops jararaca no estágio quiescente.

\begin{tabular}{|c|c|c|c|c|c|c|c|c|}
\hline $\begin{array}{c}\mathbf{N}^{\circ} \text { Spot } \\
\text { 0 dia }\end{array}$ & Proteína & $\begin{array}{l}\text { Número } \\
\text { acesso }\end{array}$ & $\begin{array}{l}\text { Proteína } \\
-10 \lg P\end{array}$ & $\begin{array}{c}\text { Cobertura } \\
\%\end{array}$ & Peptídeo & Organismo & Localização celular & Processo biológico \\
\hline \multirow[t]{2}{*}{ 71\# } & $\begin{array}{l}\text { Coagulation factor IX/ factor X- } \\
\text { binding protein subunit beta }\end{array}$ & 82116580 & 43.33 & 50 & 1 & Bothrops jararaca & Secretada - CTL & $\begin{array}{c}\text { Blood coagulation cascade } \\
\underline{\text { inhibiting toxin }}\end{array}$ \\
\hline & $\begin{array}{c}\text { Glycoprotein IB-binding protein } \\
\text { subunit } \beta\end{array}$ & 82116883 & 93.69 & 42 & 4 & Bothrops jararaca & Secretada - CTL & $\begin{array}{l}\frac{\text { Hemostasis impairing toxin }}{\text { Platelet aggregation inhibiting }} \\
\underline{\text { toxin }}\end{array}$ \\
\hline 72\# & $\begin{array}{l}\text { Snake venom vascular endothelial } \\
\text { growth factor toxin }\end{array}$ & 48428663 & 32.71 & 13 & 1 & Bothrops jararaca & Secretada - svVEGF & Angiogenesis, Differentiation \\
\hline
\end{tabular}

Nota: (*) Dados obtidos no banco de dados Metazoa nr 19082011 e Proteopeptidome_NCBInr_29042012 do MALDI-TOF/TOF

(\#) Dados obtidos no banco de dados Metazoa nr 19082011 e Proteopeptidome_NCBInr_29042012 do Orbitrap

Retículo endoplasmático (ER), Lectinas tipo C (CTL), Serinoproteinases (SVSP), Proteínas secretadas ricas em cisteína (CRISP), Classes de Metaloproteinases (PI, PII, PIII), Fosfolipases A2 (PLA2), L-aminoácido oxidase (LAAO), Glutaminil Ciclotransferase, (GC), Fator de crescimento do endotélio vascular de serpente (svVEGF). 
APÊNDICE B 
APÊNDICE B - Proteínas identificadas dos spots específicos do gel 2-DE das glândulas de veneno da serpente Bothrops jararaca no estágio ativado 4 dias após a extração de veneno.

\begin{tabular}{|c|c|c|c|c|c|c|c|c|}
\hline $\begin{array}{c}\mathbf{N}^{0} \text { Spot } \\
4 \text { dias }\end{array}$ & Proteína & $\begin{array}{l}\text { Número } \\
\text { acesso }\end{array}$ & $\begin{array}{l}\text { Proteína } \\
-10 \lg P\end{array}$ & $\begin{array}{c}\text { Cobertura } \\
\%\end{array}$ & Peptídeo & Organismo & Localização Celular & Processo Biológico \\
\hline $1^{*}$ & Similar to GRP94 & 149637905 & 1513.94 & 8 & 7 & Ornithorhynchus anatinus & Retículo endoplasmático & $\begin{array}{l}\text { Protein folding, Anti- } \\
\text { apoptosis }\end{array}$ \\
\hline $2 *$ & Botroxstatin-1 & 205278803 & 540.72 & 7 & 2 & Bothrops jararaca & Secretada - PIII & - \\
\hline \multirow[t]{2}{*}{ 3\# } & Calreticulin & 44969651 & 140.41 & 45 & 20 & Gallus gallus & Retículo endoplasmático & Protein folding \\
\hline & Anti-hemorragic fator BJ46a & 48428681 & 96.88 & 33 & 10 & Bothrops jararaca & Secretada & $\begin{array}{c}\text { Negative regulation of } \\
\text { proteolysis }\end{array}$ \\
\hline $4 *$ & $78 \mathrm{kDa}$ glucose regulated protein & 47085775 & 2054.93 & 11 & 5 & Danio rerio & Retículo endoplasmático & ER overload response \\
\hline \multirow[t]{2}{*}{$5^{*}$} & Similar heat shock protein isoform 2 & 126309857 & 691.16 & 6 & 3 & Monodelphis domestica & Citoplasma & Stress response \\
\hline & Zinc metalloproteinase $\mathrm{BnP} 2$ & 172044592 & 222.23 & 29 & 2 & Bothropoides pauloensis & Secretada - PI & Apoptosis \\
\hline \multirow[t]{4}{*}{ 6\# } & HSP70 & 63146078 & 161.76 & 44 & 21 & Oxyuranus scutellatus & Citoplasma & Stress response \\
\hline & L-amino acid oxidase precursor & 195927838 & 146.12 & 34 & 18 & Bothropoides pauloensis & Secretada - LAAO & Apoptosis, Cytolysis, \\
\hline & Ecto-5'-nucleotidase & 211926756 & 112.78 & 19 & 9 & Gloydius b. brevicaudus & Membrana & Hemolysis \\
\hline & & & & & & & & Nucleotide catabolic process \\
\hline \multirow[t]{3}{*}{ 7\# } & L-amino-acid oxidase precursor & 195927838 & 175.77 & 37 & 18 & Bothropoides pauloensis & Secretada - LAAO & Apoptosis, Cytolysis, \\
\hline & Ecto-5-nucleotidase & 211926754 & 164.45 & 30 & 14 & Gloydius b. brevicaudus & Membrana & Hemolysis \\
\hline & HSP70 & 63146078 & 141.88 & 20 & 10 & Oxyuranus scutellatus & Citoplasma & $\begin{array}{c}\text { Nucleotide catabolic process } \\
\text { Stress response }\end{array}$ \\
\hline $8^{*}$ & L-amino-acid oxidase & 82127389 & 690.10 & 6 & 3 & Bothrops moojeni & Secretada - LAAO & $\begin{array}{c}\text { Apoptosis, Cytolysis, } \\
\text { Hemolysis }\end{array}$ \\
\hline 9* & L-amino-acid oxidase & 82127389 & 1159.00 & 9 & 4 & Bothrops moojeni & Secretada - LAAO & $\begin{array}{l}\text { Apoptosis, Cytolysis, } \\
\text { Hemolysis }\end{array}$ \\
\hline $10 *$ & L-amino-acid oxidase & 82127389 & 742.02 & 7 & 3 & Bothrops moojeni & Secretada - LAAO & $\begin{array}{l}\text { Apoptosis, Cytolysis, } \\
\text { Hemolysis }\end{array}$ \\
\hline 11\# & L-amino-acid oxidase & 82127389 & 246.58 & 4 & 2 & Bothrops moojeni & Secretada - LAAO & $\begin{array}{c}\text { Apoptosis, Cytolysis, } \\
\text { Hemolysis }\end{array}$ \\
\hline
\end{tabular}


APÊNDICE B - Proteínas identificadas dos spots específicos do gel 2-DE das glândulas de veneno da serpente Bothrops jararaca no estágio ativado 4 dias após a extração de veneno.

\begin{tabular}{|c|c|c|c|c|c|c|c|c|}
\hline $\begin{array}{l}\mathbf{N}^{0} \text { Spot } \\
4 \text { dias }\end{array}$ & Proteína & $\begin{array}{l}\text { Número } \\
\text { acesso }\end{array}$ & $\begin{array}{c}\text { Proteína } \\
\text {-10lgP }\end{array}$ & $\begin{array}{c}\text { Cobertura } \\
\%\end{array}$ & Peptídeo & Organismo & Localização Celular & $\frac{\text { (continuação) }}{\text { Processo Biológico }}$ \\
\hline 12\# & L-amino-acid oxidase & 82127389 & 1115.92 & 8 & 4 & Bothrops moojeni & Secretada - LAAO & $\begin{array}{c}\text { Apoptosis, Cytolysis, } \\
\text { Hemolysis }\end{array}$ \\
\hline \multirow[t]{2}{*}{ 13\# } & Protein disulfide isomerase & 63146076 & 1854.11 & 12 & 5 & Oxyuranus scutellatus & Retículo endoplasmático & $\begin{array}{c}\text { Homeostasis, Metabolic and } \\
\text { apoptotic process }\end{array}$ \\
\hline & Ant-ihemorragic fator BJ46a & 48428681 & 109.5 & 29 & 6 & Bothrops jararaca & Secretada & $\begin{array}{c}\text { Negative regulation of } \\
\text { proteolysis }\end{array}$ \\
\hline \multirow[t]{4}{*}{ 14\# } & L-amino-acid oxidase & 82127389 & 1501.57 & 11 & 5 & Bothrops moojeni & Secretada - LAAO & Apoptosis, Cytolysis, \\
\hline & Protein disulfide isomerase & 63146076 & 211.54 & 48 & 27 & Oxyuranus scutellatus & Retículo endoplasmático & Hemolysis \\
\hline & & & & & & & & $\begin{array}{c}\text { Homeostasis, Metabolic and } \\
\text { apoptotic process }\end{array}$ \\
\hline & Anti-hemorragic fator BJ46a & 48428681 & 187.67 & 47 & 24 & Bothrops jararaca & Secretada & $\begin{array}{c}\text { Negative regulation of } \\
\text { proteolysis }\end{array}$ \\
\hline $15^{*}$ & $\begin{array}{l}\text { Protein disulfide isomerase family } \\
\qquad \text { A, member } 3\end{array}$ & 148226947 & 238.30 & 3 & 2 & Xenopus laevis & Retículo endoplasmático & $\begin{array}{c}\text { Homeostasis, Metabolic and } \\
\text { apoptotic process }\end{array}$ \\
\hline $16^{*}$ & $\begin{array}{l}\text { Protein disulfide isomerase family } \\
\qquad \text { A, member } 3\end{array}$ & 148226947 & 555.50 & 3 & 2 & Xenopus laevis & Retículo endoplasmático & $\begin{array}{c}\text { Homeostasis, Metabolic and } \\
\text { apoptotic process }\end{array}$ \\
\hline \multirow[t]{2}{*}{ 17\# } & $\begin{array}{l}\text { Protein disulfide isomerase family } \\
\qquad \text { A3-like }\end{array}$ & 327288524 & 108.97 & 20 & 8 & Anolis carolinensis & Retículo endoplasmático & $\begin{array}{c}\text { Homeostasis, Metabolic and } \\
\text { apoptotic process }\end{array}$ \\
\hline & L-amino acid oxidase & 82127389 & 102.84 & 22 & 8 & Bothrops moojeni & Secretada - LAAO & $\begin{array}{c}\text { Apoptosis, Cytolysis, } \\
\text { Hemolysis }\end{array}$ \\
\hline $18^{*}$ & $\begin{array}{l}\text { Protein disulfide isomerase family } \\
\qquad \text { A, member } 3\end{array}$ & 148226947 & 554.69 & 3 & 2 & Xenopus laevis & Retículo endoplasmático & $\begin{array}{c}\text { Homeostasis, Metabolic and } \\
\text { apoptotic process }\end{array}$ \\
\hline \multirow[t]{2}{*}{ 19\# } & $\begin{array}{c}\text { Protein disulfide isomerase } \\
\text { associated } 3\end{array}$ & 149023097 & 96.58 & 13 & 4 & Rattus novergicus & Retículo endoplasmático & $\begin{array}{c}\text { Homeostasis, Metabolic and } \\
\text { apoptotic process }\end{array}$ \\
\hline & L-amino acid oxidase precursor & 195927838 & 87.54 & 20 & 5 & Bothropoides pauloensis & Secretada - LAAO & $\begin{array}{c}\text { Apoptosis, Cytolysis, } \\
\text { Hemolysis }\end{array}$ \\
\hline
\end{tabular}


APÊNDICE B - Proteínas identificadas dos spots específicos do gel 2-DE das glândulas de veneno da serpente Bothrops jararaca no estágio ativado 4 dias após a extração de veneno.

\begin{tabular}{|c|c|c|c|c|c|c|c|c|}
\hline $\begin{array}{l}\mathrm{N}^{0} \text { Spot } \\
4 \text { dias }\end{array}$ & Proteína & $\begin{array}{l}\text { Número } \\
\text { acesso }\end{array}$ & $\begin{array}{l}\text { Proteína } \\
-10 \operatorname{lgP}\end{array}$ & $\begin{array}{c}\text { Cobertura } \\
\%\end{array}$ & Peptídeo & Organismo & Localização Celular & Processo Biológico \\
\hline \multirow[t]{2}{*}{ 20\# } & Venom serine proteinase HS114 & 82233395 & 80.28 & 34 & 4 & Bothrops jararaca & Secretada - SVSP básico & Proteolysis \\
\hline & $\begin{array}{c}\text { Zinc metalloprotease-disintegrin } \\
\text { halysase }\end{array}$ & 82211845 & 112.78 & 15 & 10 & Gloydius halys & Secretada - PIII & Apoptosis \\
\hline \multirow[t]{2}{*}{ 21\# } & Vimentin & 17386168 & 138.38 & 25 & 12 & Daboia russellii & Citoesqueleto & $\begin{array}{l}\text { Intermediate filament } \\
\text { organization }\end{array}$ \\
\hline & Protein disulfide isomerase A6-like & 327261229 & 78.75 & 20 & 5 & Anolis carolinensis & Retículo endoplasmático & $\begin{array}{c}\text { Homeostasis, Metabolic and } \\
\text { apoptotic process }\end{array}$ \\
\hline 22\# & Anti-hemorragic fator BJ46a & 48428681 & 116.81 & 26 & 8 & Bothrops jararaca & Secretada & $\begin{array}{c}\text { Negative regulation of } \\
\text { proteolysis }\end{array}$ \\
\hline 23\# & Gamma enolase & 197101563 & 196.25 & 9 & 2 & Pongo abelii & Citoplasma & Glycolysis \\
\hline $24 *$ & Gamma enolase & 197101563 & 243.90 & 9 & 2 & Pongo abelii & Citoplasma & Glycolysis \\
\hline \multirow[t]{3}{*}{ 25\# } & Vimentin & 17386168 & 186.95 & 42 & 20 & Daboia russellii & Citoesqueleto & $\begin{array}{l}\text { Intermediate filament } \\
\text { organization }\end{array}$ \\
\hline & Actin, alpha skeletal muscle & 67462115 & 156.53 & 42 & 14 & Atractaspis microlepidota & Citoesqueleto & $\begin{array}{l}\text { Structural element, } \\
\text { organization }\end{array}$ \\
\hline & Protein disulfide isomerase & 63146076 & 145.21 & 23 & 14 & Oxyuranus scutellatus & Retículo endoplasmático & $\begin{array}{c}\text { Homeostasis, Metabolic and } \\
\text { apoptotic process }\end{array}$ \\
\hline \multirow[t]{2}{*}{$26 *$} & Beta actin & 296434064 & 1340.60 & 19 & 3 & Gloydius brevicaudus & Citoesqueleto & $\begin{array}{l}\text { Structural element, } \\
\text { organization }\end{array}$ \\
\hline & Actin, alpha skeletal muscle & 67462115 & 1003.24 & 9 & 3 & Atractaspis microlepidota & Citoesqueleto & $\begin{array}{l}\text { Skeletal muscle fiber } \\
\text { development }\end{array}$ \\
\hline $27^{*}$ & Beta actin & 49868 & 1974.69 & 23 & 6 & Mus musculus & Citoesqueleto & $\begin{array}{l}\text { Structural element, } \\
\text { organization }\end{array}$ \\
\hline \multirow[t]{2}{*}{$28 *$} & Gamma actin & 809561 & 1694.62 & 22 & 6 & Mus musculus & Citoesqueleto & Structural element, \\
\hline & Beta actin & 49868 & 1692.76 & 23 & 6 & Mus musculus & Citoesqueleto & organization \\
\hline
\end{tabular}


APÊNDICE B - Proteínas identificadas dos spots específicos do gel 2-DE das glândulas de veneno da serpente Bothrops jararaca no estágio ativado 4 dias após a extração de veneno.

\begin{tabular}{|c|c|c|c|c|c|c|c|c|}
\hline $\begin{array}{c}\mathrm{N}^{0} \text { Spot } \\
4 \text { dias }\end{array}$ & Proteína & $\begin{array}{l}\text { Número } \\
\text { acesso }\end{array}$ & $\begin{array}{c}\text { Proteína } \\
-10 \lg P\end{array}$ & $\begin{array}{c}\text { Cobertura } \\
\%\end{array}$ & Peptídeo & Organismo & Localização Celular & Processo Biológico \\
\hline \multirow[t]{2}{*}{$29 *$} & Beta actin & 49868 & 1714.93 & 23 & 6 & Mus musculus & Citoesqueleto & $\begin{array}{l}\text { Structural element, } \\
\text { organization }\end{array}$ \\
\hline & Alpha muscle actin & 1703139 & 633.61 & 11 & 3 & Styela clava & Citoesqueleto & $\begin{array}{l}\text { Skeletal muscle fiber } \\
\text { development }\end{array}$ \\
\hline \multirow[t]{2}{*}{$30 *$} & Beta actin & 296434064 & 1340.60 & 19 & 3 & Gloydius brevicaudus & Citoesqueleto & Structural element, \\
\hline & Actin, alpha skeletal muscle & 67462115 & 1128.07 & 13 & 4 & Atractaspis microlepidota & Citoesqueleto & organization \\
\hline \multirow[t]{2}{*}{$31^{*}$} & Citrate synthase Mitochondrial & 116243059 & 834.26 & 12 & 5 & Amblyrhynchus cristatus & Mitocôndria & $\begin{array}{l}\text { Cellular carbohydrate } \\
\text { metabolic process }\end{array}$ \\
\hline & Isocitrate dehydrogenase 1 & 52345632 & 524.85 & 5 & 2 & Xenopus tropicalis & Citoplasma & Isocitrate metabolic process \\
\hline \multirow[t]{2}{*}{ 32\# } & $\begin{array}{l}\text { Medium-chain specific acyl-coA } \\
\text { dehydrogenase, Mitochondrial-like }\end{array}$ & 377276681 & 152.88 & 37 & 8 & Macropus eugenii & Mitocôndria & Lipid metabolism \\
\hline & Actin, alpha skeletal muscle & 67462115 & 101.76 & 19 & 6 & Atractaspis microlepidota & Citoesqueleto & $\begin{array}{l}\text { Skeletal muscle fiber } \\
\text { development }\end{array}$ \\
\hline \multirow[t]{3}{*}{ 33\# } & Venom serine proteinase HS114 & 82233395 & 124.03 & 51 & 10 & Bothrops jararaca & Secretada - SVSP ácido & Proteolysis \\
\hline & Tropomyosin beta chain isoform 2 & 47519616 & 97.70 & 23 & 5 & Homo sapiens & Citoesqueleto & Muscle contraction \\
\hline & Plasminogen-activating proteinase & 123891732 & 61.97 & 31 & 3 & Lachesis muta muta & Secretada - SVSP ácido & $\begin{array}{c}\text { Proteolysis, Regulation blood } \\
\text { pressure }\end{array}$ \\
\hline \multirow[t]{2}{*}{ 34* } & Venom serine proteinase HS114 & 82233395 & 1340.60 & 22 & 3 & Bothrops jararaca & Secretada - SVSP ácido & Proteolysis \\
\hline & Cytoskeletal tropomyosin & 833603 & 80.77 & 8 & 2 & Coturnix coturnix & Citoesqueleto & Muscle contraction \\
\hline 35\# & Venom serine proteinase HS114 & 82233395 & 2068.66 & 34 & 6 & Bothrops jararaca & Secretada - SVSP ácido & Proteolysis \\
\hline \multirow[t]{2}{*}{ 36\# } & Venom serine proteinase HS114 & 82233395 & 1585.41 & 29 & 5 & Bothrops jararaca & Secretada - SVSP ácido & Proteolysis \\
\hline & Tropomyosion-1 alpha chain & 221219564 & 102.41 & 28 & 11 & Salmo salar & Citoesqueleto & Muscle contraction \\
\hline \multirow[t]{2}{*}{ 37\# } & Venom serine proteinase HS114 & 82233395 & 2063.65 & 69 & 24 & Bothrops jararaca & Secretada - SVSP ácido & Proteolysis \\
\hline & Plasminogen-activating proteinase & 123891732 & 116.79 & 30 & 15 & Lachesis muta muta & Secretada - SVSP ácido & $\begin{array}{c}\text { Proteolysis, Regulation blood } \\
\text { pressure }\end{array}$ \\
\hline
\end{tabular}


APÊNDICE B - Proteínas identificadas dos spots específicos do gel 2-DE das glândulas de veneno da serpente Bothrops jararaca no estágio ativado 4 dias após a extração de veneno.

\begin{tabular}{|c|c|c|c|c|c|c|c|c|}
\hline $\begin{array}{l}\mathbf{N}^{0} \text { Spot } \\
4 \text { dias }\end{array}$ & Proteína & $\begin{array}{l}\text { Número } \\
\text { acesso }\end{array}$ & $\begin{array}{l}\text { Proteína } \\
-10 \lg P\end{array}$ & $\begin{array}{c}\text { Cobertura } \\
\%\end{array}$ & Peptídeo & Organismo & Localização Celular & $\frac{(\text { continuaçăo })}{\text { Processo Biológico }}$ \\
\hline \multirow[t]{2}{*}{ 38\# } & Protein disulfide isomerase & 63146076 & 154.32 & 44 & 17 & Oxyuranus scutellatus & Retículo endoplasmático & $\begin{array}{c}\text { Cell Homeostasis, Metabolic } \\
\text { and apoptotic process }\end{array}$ \\
\hline & Venom serine proteinase-like & 123883733 & 107.16 & 42 & 15 & Bothrops asper & Secretada - SVSP ácido & Proteolysis \\
\hline $39 *$ & Venom serine proteinase HS114 & 8223395 & 1165.17 & 22 & 4 & Bothrops jararaca & Secretada - SVSP ácido & Proteolysis \\
\hline \multirow[t]{3}{*}{ 40\# } & Lipocortin V & 2981437 & 74.50 & 15 & 5 & Rattus novergicus & Citoplasma & $\begin{array}{c}\text { Blood coagulation, } \\
\text { Homeostasis }\end{array}$ \\
\hline & Venom serine proteinase HS114 & 82233395 & 110.81 & 51 & 9 & Bothrops jararaca & Secretada - SVSP ácido & Proteolysis \\
\hline & Plasminogen-activating proteinase & 123891732 & 103.92 & 33 & 10 & Lachesis muta & Secretada - SVSP ácido & $\begin{array}{c}\text { Proteolysis, Regulation blood } \\
\text { pressure }\end{array}$ \\
\hline $41 *$ & Annexin A2 & 45382533 & 1339.47 & 15 & 6 & Gallus gallus & Secretada & Fibrinolysis \\
\hline $42 *$ & Annexin A2 & 45382533 & 1165.11 & 12 & 5 & Gallus gallus & Secretada & Fibrinolysis \\
\hline \multirow[t]{3}{*}{ 43\# } & Annexin A2 & 45382533 & 1025.90 & 12 & 4 & Gallus gallus & Secretada & Fibrinolysis \\
\hline & Similar to gag polyprotein & 149410850 & 646.82 & 9 & 3 & Ornithorhynchus anatinus & Membrana & Structural molecule activity \\
\hline & Venom serine protease homolog & 82240434 & 94.17 & 17 & 4 & Bothrops jararacussu & Secretada - SVSP básico & Metabolic process \\
\hline $44 *$ & $\begin{array}{l}\text { Cysteine rich secretory protein Da- } \\
\qquad \mathrm{CRPb}\end{array}$ & 190195339 & 892.07 & 12 & 2 & Deinagkistrodon acutus & Secretada - CRISP & - \\
\hline $45^{*}$ & $\begin{array}{l}\text { Cysteine rich secretory protein Da- } \\
\qquad \mathrm{CRPb}\end{array}$ & 190195339 & 1340.60 & 16 & 3 & Deinagkistrodon acutus & Secretada - CRISP & \\
\hline $46^{*}$ & $\begin{array}{l}\text { Guanine nucleotide-binding protein } \\
\text { subunit beta-2-like } 1\end{array}$ & 194375063 & 1013.51 & 15 & 3 & Homo sapiens & Membrana & $\begin{array}{c}\text { Adenylate cyclase-activating } \\
\text { G-protein coupled receptor } \\
\text { pathway }\end{array}$ \\
\hline $47 *$ & $\begin{array}{l}\text { Voltage-dependent anion selective } \\
\text { channel protein 2-like }\end{array}$ & 327276833 & 1340.60 & 13 & 3 & Anolis carolinensis & Mitocôndria & Ion transport \\
\hline \multirow[t]{2}{*}{$48 \#$} & Plasminogen activator Haly-HA & 156630858 & 121.96 & 15 & 9 & Gloydius brevicaudus & Secretada - SVSP neutro & $\begin{array}{c}\text { Proteolysis, Regulation blood } \\
\text { pressure }\end{array}$ \\
\hline & Serine proteinase isoform 4 & 109254944 & 115.92 & 16 & 8 & Sistrurus catenatus & Secretada - SVSP neutro & Proteolysis \\
\hline
\end{tabular}


APÊNDICE B - Proteínas identificadas dos spots específicos do gel 2-DE das glândulas de veneno da serpente Bothrops jararaca no estágio ativado 4 dias após a extração de veneno.

\begin{tabular}{|c|c|c|c|c|c|c|c|c|}
\hline $\begin{array}{l}\mathrm{N}^{\circ} \text { Spot } \\
4 \text { dias }\end{array}$ & Proteína & $\begin{array}{l}\text { Número } \\
\text { acesso }\end{array}$ & $\begin{array}{l}\text { Proteína } \\
\text {-10lgP }\end{array}$ & $\begin{array}{c}\text { Cobertura } \\
\%\end{array}$ & Peptídeo & Organismo & Localização Celular & Processo Biológico \\
\hline & & & & & & edwardsi & & \\
\hline \multirow[t]{2}{*}{ 49\# } & $\begin{array}{c}\text { Proteasome subunit alpha type-6- } \\
\text { like }\end{array}$ & 327263622 & 79.54 & 23 & 4 & Anolis carolinensis & Citoplasma & $\begin{array}{l}\text { Ubiquitin-dependent protein } \\
\text { catabolic process }\end{array}$ \\
\hline & C-type lectin BiL & 82126834 & 67.18 & 30 & 4 & Bothrops insularis & Secretada - CTL & Hemagglutinating activity \\
\hline 50\# & $\begin{array}{l}\text { Cysteine-rich secretory protein } \mathrm{Da}- \\
\qquad \mathrm{CRPb}\end{array}$ & 190195339 & 65.40 & 28 & 3 & Deinagkistrodon acutus & Secretada - CRISP & - \\
\hline \multirow[t]{2}{*}{ 51\# } & Protein disulfide isoemrase & 63146076 & 151.12 & 40 & 16 & Oxyuranus scutellatus & Retículo endoplasmático & $\begin{array}{c}\text { Homeostasis, Metabolic and } \\
\text { apoptotic process }\end{array}$ \\
\hline & Gluthatione S-transferase Mu 1-like & 327270920 & 91.53 & 32 & 5 & Anolis carolinensis & Citoplasma & $\begin{array}{c}\text { Gluthatione metabolic } \\
\text { process }\end{array}$ \\
\hline \multirow[t]{2}{*}{$52 *$} & Gamma phospholipase A2 inhibitor & 157885066 & 1444.23 & 22 & 4 & Bothrops jararaca & Secretada - PLI & $\begin{array}{l}\text { Regulation of phospholipase } \\
\qquad \text { A2 activity }\end{array}$ \\
\hline & Zinc metalloproteinase $\mathrm{BnP} 2$ & 172044592 & 566.31 & 29 & 2 & Bothropoides pauloensis & Secretada - PI & Apoptosis \\
\hline 53\# & $\begin{array}{l}\text { Zinc metalloproteinase-disintegrin } \\
\text { HF3 }\end{array}$ & 82219706 & 100.51 & 19 & 8 & Bothrops jararaca & Secretada - PIII & Proteolysis \\
\hline $54 *$ & Zinc metalloproteinase $\mathrm{BnP} 2$ & 172044592 & 966.29 & 29 & 2 & Bothropoides pauloensis & Secretada - PI & Apoptosis \\
\hline $55^{*}$ & $\begin{array}{l}\text { Zinc metalloproteinase } \\
\text { bothrojaractivase }\end{array}$ & 187655925 & 551.37 & 37 & 2 & Bothrops jararaca & Secretada - PI & Proteolysis \\
\hline $56^{*}$ & $\begin{array}{c}\text { Zinc metalloproteinase } \\
\text { bothrojaractivase }\end{array}$ & 187655925 & 524.92 & 37 & 2 & Bothrops jararaca & Secretada - PI & Proteolysis \\
\hline 57\# & Zinc metalloproteinase $\mathrm{BnP} 2$ & 172044592 & 133.65 & 93 & 9 & Bothropoides pauloensis & Secretada - PI & Apoptosis \\
\hline \multirow[t]{2}{*}{ 58\# } & $\begin{array}{l}\text { Zinc metalloproteinase } \\
\text { bothrojaractivase }\end{array}$ & 187655925 & 550.15 & 37 & 2 & Bothrops jararaca & Secretada - PI & Proteolysis \\
\hline & Proteasome-like protein & 71725697 & 97.36 & 25 & 4 & Oxyuranus scutellatus & Citoplasma & $\begin{array}{l}\text { Ubiquitin-dependent protein } \\
\text { catabolic process }\end{array}$ \\
\hline
\end{tabular}


APÊNDICE B - Proteínas identificadas dos spots específicos do gel 2-DE das glândulas de veneno da serpente Bothrops jararaca no estágio ativado 4 dias após a extração de veneno.

\begin{tabular}{|c|c|c|c|c|c|c|c|c|}
\hline $\begin{array}{c}\mathrm{N}^{0} \text { Spot } \\
4 \text { dias }\end{array}$ & Proteína & $\begin{array}{l}\text { Número } \\
\text { acesso }\end{array}$ & $\begin{array}{c}\text { Proteína } \\
-10 \lg P\end{array}$ & $\begin{array}{c}\text { Cobertura } \\
\%\end{array}$ & Peptídeo & Organismo & Localização Celular & Processo Biológico \\
\hline 59\# & $\begin{array}{c}\text { Alpha-type phospholipase A2 } \\
\text { inhibitor }\end{array}$ & 215275475 & 526.74 & 12 & 2 & Bothrops jararaca & Secretada - PLI & $\begin{array}{l}\text { Regulation of phospholipase } \\
\text { A2 activity }\end{array}$ \\
\hline $60 *$ & $\begin{array}{c}\text { Alpha-type phospholipase A2 } \\
\text { inhibitor }\end{array}$ & 215275475 & 579.71 & 12 & 2 & Bothrops jararaca & Secretada - PLI & $\begin{array}{l}\text { Regulation of phospholipase } \\
\qquad \text { A2 activity }\end{array}$ \\
\hline $61^{*}$ & $\begin{array}{c}\text { Translocon-associated protein-like } \\
\text { protein }\end{array}$ & 71725701 & 892.07 & 19 & 2 & Oxyuranus scutellatus & Retículo endoplasmático & $\begin{array}{l}\text { Cotranslational protein } \\
\text { targeting to membrane }\end{array}$ \\
\hline 62\# & $\begin{array}{l}\text { Actin, alpha skeletal muscle } \\
\text { Venom gland cyclophilin }\end{array}$ & $\begin{array}{l}67462115 \\
38374146\end{array}$ & $\begin{array}{l}119.00 \\
151.76\end{array}$ & $\begin{array}{l}30 \\
48\end{array}$ & $\begin{array}{l}7 \\
6\end{array}$ & $\begin{array}{c}\text { Atractaspis microlepidota } \\
\text { Bitis gabonica }\end{array}$ & $\begin{array}{l}\text { Citoesqueleto } \\
\text { Citoplasma }\end{array}$ & $\begin{array}{c}\text { Skeletal muscle fiber } \\
\text { development } \\
\text { Protein folding }\end{array}$ \\
\hline $63^{*}$ & $\begin{array}{l}\text { Thioredoxin domain-contain } \\
\text { protein } 12\end{array}$ & 119672905 & 892.07 & 12 & 2 & Danio rerio & Citoplasma & Cell redox homeostasis \\
\hline 64\# & Venom gland cyclophilin & 38374146 & 200.46 & 67 & 19 & Bitis gabonica & Citoplasma & Protein folding \\
\hline 65\# & C-type lectin BiL & 82126834 & 97.68 & 27 & 3 & Bothrops insularis & Secretada - CTL & Hemagglutinating activity \\
\hline 66\# & $\begin{array}{c}\text { C-type lectin BiL } \\
\text { Galactose-specific lectin }\end{array}$ & $\begin{array}{l}82126834 \\
34922459\end{array}$ & $\begin{array}{c}1403.99 \\
186.32\end{array}$ & $\begin{array}{l}30 \\
70\end{array}$ & $\begin{array}{c}6 \\
22\end{array}$ & $\begin{array}{l}\text { Bothrops insularis } \\
\text { Bothrops jararacussu }\end{array}$ & $\begin{array}{l}\text { Secretada - CTL } \\
\text { Secretada - CTL }\end{array}$ & $\begin{array}{l}\text { Hemagglutinating activity } \\
\text { Hemagglutinating activity }\end{array}$ \\
\hline $67^{*}$ & Thioredoxin & 20140734 & 627.17 & 23 & 3 & Ophiophagus hannah & Citoplasma & Cell redox homeostase \\
\hline 68\# & $\begin{array}{c}\text { C-type lectin BiL } \\
\text { Galactose-specific lectin }\end{array}$ & $\begin{array}{l}82126834 \\
34922459\end{array}$ & $\begin{array}{c}1234.18 \\
143.20\end{array}$ & $\begin{array}{l}24 \\
87\end{array}$ & $\begin{array}{c}5 \\
18\end{array}$ & $\begin{array}{l}\text { Bothrops insularis } \\
\text { Bothrops jararacussu }\end{array}$ & $\begin{array}{l}\text { Secretada - CTL } \\
\text { Secretada - CTL }\end{array}$ & $\begin{array}{l}\text { Hemagglutinating activity } \\
\text { Hemagglutinating activity }\end{array}$ \\
\hline 69\# & $\begin{array}{c}\text { C-type lectin BiL } \\
\text { Galactose-specific lectin }\end{array}$ & $\begin{array}{l}82126834 \\
34922459\end{array}$ & $\begin{array}{c}810.60 \\
71.12\end{array}$ & $\begin{array}{l}17 \\
58\end{array}$ & $\begin{array}{l}4 \\
6\end{array}$ & $\begin{array}{c}\text { Bothrops insularis } \\
\text { Bothrops jararacussu }\end{array}$ & $\begin{array}{l}\text { Secretada - CTL } \\
\text { Secretada - CTL }\end{array}$ & $\begin{array}{l}\text { Hemagglutinating activity } \\
\text { Hemagglutinating activity }\end{array}$ \\
\hline 70\# & $\begin{array}{c}\text { Phospholipase A2 homolog } 2 \\
\text { C-type lectin BiL }\end{array}$ & $\begin{array}{l}17865560 \\
82126834\end{array}$ & $\begin{array}{l}135.12 \\
119.32\end{array}$ & $\begin{array}{l}57 \\
44\end{array}$ & $\begin{array}{l}9 \\
6\end{array}$ & $\begin{array}{l}\text { Bothrops moojeni } \\
\text { Bothrops insularis }\end{array}$ & $\begin{array}{l}\text { Secretada - PLA } \\
\text { Secretada - CTL }\end{array}$ & $\begin{array}{l}\text { Inflammatory response } \\
\text { Hemagglutinating activity }\end{array}$ \\
\hline 71\# & $\begin{array}{l}\text { 40S Ribosomal protein S12-like } \\
\text { Bothroinsularin subunit beta }\end{array}$ & $\begin{array}{l}293347028 \\
229621685\end{array}$ & $\begin{array}{l}97.67 \\
76.19\end{array}$ & $\begin{array}{l}21 \\
34\end{array}$ & $\begin{array}{l}6 \\
4\end{array}$ & $\begin{array}{l}\text { Rattus novergicus } \\
\text { Bothrops insularis }\end{array}$ & $\begin{array}{c}\text { Citoplasma } \\
\text { Secretada - CTL }\end{array}$ & $\begin{array}{c}\text { Translation } \\
\text { Blood coagulation cascade } \\
\text { inhibiting }\end{array}$ \\
\hline
\end{tabular}


APÊNDICE B - Proteínas identificadas dos spots específicos do gel 2-DE das glândulas de veneno da serpente Bothrops jararaca no estágio ativado 4 dias após a extração de veneno.

\begin{tabular}{|c|c|c|c|c|c|c|c|c|}
\hline $\begin{array}{c}\mathrm{N}^{\mathbf{0}} \text { Spot } \\
4 \text { dias }\end{array}$ & Proteína & $\begin{array}{l}\text { Número } \\
\text { acesso }\end{array}$ & $\begin{array}{c}\text { Proteína } \\
-10 \lg P\end{array}$ & $\begin{array}{c}\text { Cobertura } \\
\%\end{array}$ & Peptídeo & Organismo & Localização Celular & Processo Biológico \\
\hline \multirow[t]{2}{*}{ 72\# } & Galectin-1-like & 327272244 & 176.12 & 61 & 18 & Anolis carolinensis & Secretada - CTL & Carbohydrate binding \\
\hline & Venom serine proteinase HS114 & 82233395 & 99.77 & 22 & 5 & Bothrops jararaca & Secretada - SVSP neutro & Proteolysis \\
\hline \multirow[t]{2}{*}{$73^{*}$} & Phospholipase A2 homolog 2 & 17865560 & 128.87 & 62 & 12 & Bothrops moojeni & Secretada - PLA 2 & Inflammatory response \\
\hline & Ribosomal protein S15 isoform & 18000277 & 108.09 & 50 & 6 & Lapemis hardwickii & Citoplasma & Translation \\
\hline \multirow[t]{2}{*}{ 74\# } & Cytochrome c & 119388034 & 55.42 & 20 & 3 & Crotalus atrox & Mitocôndria & Electron transport \\
\hline & Venom gland cyclophilin & 38374146 & 96.87 & 24 & 4 & Bitis gabonica & Citoplasma & Protein folding \\
\hline \multirow[t]{2}{*}{ 75\# } & Protein disulfide isomerase & 63146076 & 128.49 & 32 & 131 & Oxyuranus scutellatus & Retículo endoplasmático & $\begin{array}{c}\text { Homeostasis, Metabolic and } \\
\text { apoptotic process }\end{array}$ \\
\hline & Myotoxin II precursor & 7673017 & 74.81 & 25 & 3 & Bothrops moojeni & Secretada - PLA 2 & $\begin{array}{l}\text { Sodium channel inhibitor } \\
\text { activity }\end{array}$ \\
\hline 76\# & Phospholipase A2 homolog 2 & 17865560 & 81.39 & 45 & 4 & Bothrops moojeni & Secretada - PLA 2 & Inflammatory response \\
\hline 77\# & Protein disulfide isomerase & 63146076 & 96.33 & 30 & 4 & Oxyuranus scutellatus & Retículo endoplasmático & $\begin{array}{c}\text { Homeostasis, Metabolic and } \\
\text { apoptotic process }\end{array}$ \\
\hline
\end{tabular}

Nota: (*) Dados obtidos no banco de dados Metazoa nr 19082011 e Proteopeptidome_NCBInr_29042012 do MALDI-TOF/TOF

(\#) Dados obtidos no banco de dados Metazoa nr 19082011 e Proteopeptidome_NCBInr_29042012 do Orbitrap

Retículo endoplasmático (ER), Lectinas tipo C (CTL), Serinoproteinases (SVSP), Proteínas secretadas ricas em cisteína (CRISP), Classe das metaloproteinases (PI, PII, PIII), Fosfolipases A2 (PLA $)$, L-aminoácido oxidase (LAAO), Inibidores de Fosfolipases A2 (PLI). 
APÊNDICE C 
APÊNDICE C - Proteínas identificadas de spots específicos de gel 2-DE das glândulas de veneno da serpente Bothrops jararaca no estado ativado 7 dias após a extração de veneno.

\begin{tabular}{|c|c|c|c|c|c|c|c|c|}
\hline $\begin{array}{c}\mathrm{N}^{0} \text { Spot } \\
7 \text { dias }\end{array}$ & Proteína & $\begin{array}{c}\text { Número } \\
\text { acesso }\end{array}$ & $\begin{array}{c}\text { Protein } \\
-10 \operatorname{lgP}\end{array}$ & $\begin{array}{c}\text { Cobertura } \\
\%\end{array}$ & Peptídeo & Organismo & Localização Celular & Processo Biológico \\
\hline \multirow[t]{3}{*}{ 1\# } & Endoplasmin & 17865698 & 170.69 & 35 & 29 & Sus scrofa & Retículo endoplasmático & Protein folding \\
\hline & Zinc metalloproteinase-disintegrin & 82214993 & 95.84 & 28 & 10 & Bothrops insularis & Secretada - PIII & Proteolysis \\
\hline & BITM06A & & & & & & & \\
\hline \multirow[t]{2}{*}{$2 *$} & Zinc metalloproteinase-disintegrin & 82190823 & 288.30 & 12 & 5 & Bothrops jararaca & Secretada - PIII & Cell adhesion \\
\hline & bothropasin & & & & & & & \\
\hline \multirow[t]{2}{*}{ 3\# } & Calreticulin & 44969651 & 190.46 & 68 & 26 & Gallus gallus & Retículo endoplasmático & Protein folding \\
\hline & Ant-ihemorragic fator $\mathrm{Bj} 46 \mathrm{a}$ & 48428681 & 192.01 & 44 & 23 & Bothrops jararaca & Secretada & Negative regulation of proteolysis \\
\hline \multirow[t]{2}{*}{ 4\# } & Calreticulin & 44969651 & 158.43 & 43 & 24 & Gallus gallus & Retículo endoplasmático & Protein folding \\
\hline & Anti-hemorragic fator $\mathrm{Bj} 46 \mathrm{a}$ & 48428681 & 147.51 & 41 & 14 & Bothrops jararaca & Secretada & Negative regulation of proteolysis \\
\hline \multirow[t]{3}{*}{ 5\# } & $78 \mathrm{kDa}$ glucose regulated protein & 47085775 & 134.60 & 39 & 27 & Danio rerio & Retículo endoplasmático & ER overload response \\
\hline & Zinc metalloproteinase-disintegrin & 82190823 & 77.16 & 12 & 4 & Bothrops jararaca & Secretada - PIII & Cell adhesion \\
\hline & bothropasin & & & & & & & \\
\hline \multirow[t]{2}{*}{ 6\# } & HSP70 & 63146078 & 183.94 & 46 & 31 & Oxyuranus scutellatus & Citoplasma & Stress response \\
\hline & $78 \mathrm{kDa}$ glucose-regulated protein & 47085775 & 120.84 & 37 & 19 & Danio rerio & Retículo endoplasmático & ER overload response \\
\hline \multirow[t]{3}{*}{ 7\# } & HSP70 & 63146078 & 193.56 & 53 & 38 & Oxyuranus scutellatus & Citoplasma & Stress response \\
\hline & L-amino acid oxidase precursor & 82127389 & 179.66 & 49 & 89 & Bothrops moojeni & Secretada - LAAO & Apoptosis, Cytolysis, Hemolysis \\
\hline & $78 \mathrm{kDa}$ glucose-regulated protein & 47085775 & 107.34 & 32 & 15 & Danio rerio & Retículo endoplasmático & ER overload response \\
\hline \multirow[t]{2}{*}{ 8\# } & L-amino acid oxidase precursor & 82127389 & 103.22 & 25 & 11 & Bothrops moojeni & Secretada - LAAO & Apoptosis, Cytolysis, Hemolysis \\
\hline & HSP70 & 63146078 & 125.95 & 13 & 7 & Oxyuranus scutellatus & Citoplasma & Stress response \\
\hline \multirow[t]{3}{*}{ 9\# } & L-amino acid oxidase precursor & 195927838 & 185.75 & 39 & 22 & Bothropoides pauloensis & Secretada - LAAO & Apoptosis, Cytolysis, Hemolysis \\
\hline & Zinc metalloproteinase-disintegrin & 82214994 & 133.62 & 20 & 10 & Bothrops insularis & Secretada - PIII & Proteolysis \\
\hline & BITM02A & & & & & & & \\
\hline $10 *$ & Zinc metalloproteinase-disintegrin & 82214993 & 48.85 & 5 & 2 & Bothrops insularis & Secretada - PIII & Cell adhesion \\
\hline
\end{tabular}


APÊNDICE C - Proteínas identificadas de spots específicos de gel 2-DE das glândulas de veneno da serpente Bothrops jararaca no estado ativado 7 dias após a extração de veneno.

\begin{tabular}{|c|c|c|c|c|c|c|c|c|}
\hline $\begin{array}{c}\mathbf{N}^{\circ} \text { Spot } \\
7 \text { dias }\end{array}$ & Proteína & $\begin{array}{l}\text { Número } \\
\text { acesso }\end{array}$ & $\begin{array}{c}\text { Protein } \\
-10 \lg P\end{array}$ & $\begin{array}{c}\text { Cobertura } \\
\%\end{array}$ & Peptídeo & Organismo & Localização Celular & Processo Biológico \\
\hline & BITM06A & & & & & & & \\
\hline \multirow[t]{2}{*}{ 11\# } & Metalloproteinase jararafibrase-2 & 82219563 & 177.20 & 58 & 52 & Bothrops jararaca & Secretada - PII & Cell adhesion \\
\hline & Protein disulfide isomerase & 63146076 & 152.04 & 67 & 24 & Oxyuranus scutellatus & Retículo endoplasmático & $\begin{array}{c}\text { Homeostasis, Metabolic and } \\
\text { apoptotic process }\end{array}$ \\
\hline \multirow[t]{3}{*}{$12 \#$} & $\begin{array}{l}\text { Protein disulfide isomerase family } \\
\qquad \text { A3 }\end{array}$ & 327288524 & 155.52 & 68 & 25 & Anolis carolinensis & Retículo endoplasmático & $\begin{array}{c}\text { Homeostasis, Metabolic and } \\
\text { apoptotic process }\end{array}$ \\
\hline & Metalloproteinase jararafibrase 2 & 82219563 & 147.20 & 43 & 26 & Bothrops jararaca & Secretada - PII & Cell adhesion \\
\hline & $\begin{array}{l}\text { Vascular apoptosis-inducing } \\
\text { protein } 2 \mathrm{~A}\end{array}$ & 144905068 & 115.13 & 20 & 13 & Crotalus atrox & Secretada - PIII & Apoptosis \\
\hline \multirow[t]{4}{*}{ 13\# } & Metalloproteinase jararafibrase-2 & 82219563 & 147.20 & 43 & 26 & Bothrops jararaca & Secretada - PII & Cell adhesion \\
\hline & Zinc metalloproteinase-disintegrin & 82214993 & 133.40 & 35 & 22 & Bothrops insularis & Secretada - PIII & Proteolysis \\
\hline & BITM06A & & & & & & & \\
\hline & $\begin{array}{l}\text { Protein disulfide isomerase family } \\
\qquad \text { A3 }\end{array}$ & 327288524 & 79.70 & 20 & 5 & Anolis carolinensis & Retículo endoplasmático & $\begin{array}{c}\text { Homeostasis, Metabolic and } \\
\text { apoptotic process }\end{array}$ \\
\hline \multirow[t]{3}{*}{ 14\# } & $\begin{array}{l}\text { Protein disulfide isomerase family } \\
\qquad \text { A3 }\end{array}$ & 327288524 & 183.31 & 26 & 6 & Anolis carolinensis & Retículo endoplasmático & $\begin{array}{c}\text { Homeostasis, Metabolic and } \\
\text { apoptotic process }\end{array}$ \\
\hline & Metalloproteinase jararafibrase 2 & 82219563 & 73.14 & 7 & 2 & Bothrops jararaca & Secretada - PII & Cell adhesion \\
\hline & $\begin{array}{l}\text { Vascular apoptosis-inducing } \\
\text { protein } 2 \mathrm{~A}\end{array}$ & 144905068 & 119.03 & 24 & 13 & Crotalus atrox & Secretada - PIII & Apoptosis \\
\hline \multirow[t]{2}{*}{ 15\# } & Metalloproteinase jararafibrase 2 & 82219563 & 118.40 & 37 & 9 & Bothrops jararaca & Secretada - PII & Cell adhesion \\
\hline & $\begin{array}{l}\text { Protein disulfide isomerase } \\
\text { associated } 3 \text { precursor }\end{array}$ & 199599757 & 104.4 & 20 & 7 & Otolemur garnettii & Retículo endoplasmático & $\begin{array}{c}\text { Homeostasis, Metabolic and } \\
\text { Apoptotic process }\end{array}$ \\
\hline $16^{*}$ & Metalloproteinase insularinase A & 82197476 & 95.89 & 17 & 3 & Bothrops insularis & Secretada - PII & Cell adhesion \\
\hline 17\# & Metalloproteinase insularinase A & 82197476 & 115.38 & 29 & 15 & Bothrops insularis & Secretada - PII & Cell adhesion \\
\hline
\end{tabular}


APÊNDICE C - Proteínas identificadas de spots específicos de gel 2-DE das glândulas de veneno da serpente Bothrops jararaca no estado ativado 7 dias após a extração de veneno.

\begin{tabular}{|c|c|c|c|c|c|c|c|c|}
\hline $\begin{array}{l}\mathbf{N}^{0} \text { Spot } \\
7 \text { dias }\end{array}$ & Proteína & $\begin{array}{l}\text { Número } \\
\text { acesso }\end{array}$ & $\begin{array}{l}\text { Protein } \\
-10 \lg P\end{array}$ & $\begin{array}{c}\text { Cobertura } \\
\%\end{array}$ & Peptídeo & Organismo & Localização Celular & Processo Biológico \\
\hline 18\# & Metalloproteinase insularinase A & 82197476 & 134.56 & 40 & 24 & Bothrops insularis & Secretada - PII & Cell adhesion \\
\hline $19 *$ & Metalloproteinase insularinase A & 82197476 & 143.11 & 14 & 5 & Bothrops insularis & Secretada - PII & Cell adhesion \\
\hline $20 *$ & Metalloproteinase insularinase A & 82197476 & 135.54 & 15 & 5 & Bothrops insularis & Secretada - PII & Cell adhesion \\
\hline $21^{*}$ & Metalloproteinase insularinase A & 82197476 & 122.87 & 14 & 5 & Bothrops insularis & Secretada - PII & Cell adhesion \\
\hline $22 *$ & Beta actin & 58198383 & 151.05 & 25 & 4 & Pseudonaja textilis & Citoesqueleto & Structural element, organization \\
\hline 23* & Actin, alpha skeletal muscle & 67462115 & 80.20 & 7 & 2 & Atractaspis microlepidota & Citoesqueleto & Skeletal muscle fiber development \\
\hline $24 *$ & Beta actin & 58198383 & 268.11 & 25 & 4 & Pseudonaja textilis & Citoesqueleto & Structural element, organization \\
\hline $25^{*}$ & Actin, alpha skeletal muscle & 67462115 & 122.04 & 13 & 3 & Atractaspis microlepidota & Citoesqueleto & Skeletal muscle fiber development \\
\hline \multirow[t]{2}{*}{$26^{*}$} & Actin, alpha skeletal muscle & 67462115 & 192.53 & 16 & 5 & Atractaspis microlepidota & Citoesqueleto & Skeletal muscle fiber development \\
\hline & Beta actin & 58198383 & 186.94 & 25 & 4 & Pseudonaja textilis & Citoesqueleto & Structural element, organization \\
\hline \multirow[t]{2}{*}{$27 *$} & Actin, alpha skeletal muscle & 67462115 & 175.71 & 62 & 42 & Atractaspis microlepidota & Citoesqueleto & Skeletal muscle fiber development \\
\hline & Beta actin & 296434064 & 181.05 & 71 & 41 & Gloydius brevicaudus & Citoesqueleto & Structural element, organization \\
\hline $28 *$ & Beta actin & 58198383 & 124.65 & 25 & 3 & Pseudonaja textilis & Citoesqueleto & Structural element, organization \\
\hline 29\# & Actin, alpha cardiac muscle 1 & 335279921 & 121.13 & 12 & 2 & Sus scrofa & Citoesqueleto & Skeletal muscle fiber development \\
\hline 30\# & Venom serine proteinase-like & 123883733 & 127.50 & 40 & 16 & Bothrops asper & Secretada - SVSP ácido & Metabolic process \\
\hline \multirow[t]{2}{*}{ 31\# } & Protein disulfide isomerase & 63146076 & 146.15 & 34 & 19 & Oxyuranus scutellatus & Retículo endoplasmático & $\begin{array}{c}\text { Homeostasis, Metabolic and } \\
\text { Apoptotic process }\end{array}$ \\
\hline & $\begin{array}{l}\text { Kinin-releasing and fibrinogen- } \\
\text { clotting serine proteinase } 2\end{array}$ & 13959622 & 138.46 & 60 & 20 & Bothrops jararaca & Secretada - SVSP ácido & $\begin{array}{c}\text { Proteolysis, Regulation of blood } \\
\text { pressure }\end{array}$ \\
\hline \multirow[t]{4}{*}{ 32\# } & Vimentin & 17386168 & 148.56 & 35 & 17 & Daboia russellii & Citoesqueleto & Intermediate filament organization \\
\hline & Protein disulfide isomerase & 63146076 & 136.06 & 35 & 17 & Oxyuranus scutellatus & Retículo endoplasmático & $\begin{array}{c}\text { Homeostasis, Metabolic and } \\
\text { Apoptotic process }\end{array}$ \\
\hline & Venom serine proteinase-like & 123883733 & 131.02 & 35 & 17 & Bothrops asper & Secretada - SVSP ácido & Metabolic process \\
\hline & $78 \mathrm{kDa}$ glucose regulated protein & 47085775 & 126.52 & 16 & 13 & Danio rerio & Retículo endoplasmático & ER overload response \\
\hline
\end{tabular}


APÊNDICE C - Proteínas identificadas de spots específicos de gel 2-DE das glândulas de veneno da serpente Bothrops jararaca no estado ativado 7 dias após a extração de veneno.

\begin{tabular}{|c|c|c|c|c|c|c|c|c|}
\hline $\begin{array}{l}N^{0} \text { Spot } \\
7 \text { dias }\end{array}$ & Proteína & $\begin{array}{l}\text { Número } \\
\text { acesso }\end{array}$ & $\begin{array}{l}\text { Protein } \\
-10 \lg P\end{array}$ & $\begin{array}{c}\text { Cobertura } \\
\%\end{array}$ & Peptídeo & Organismo & Localização Celular & Processo Biológico \\
\hline 33\# & Venom serine proteinase-like & 123883733 & 98.12 & 22 & 5 & Bothrops asper & Secretada - SVSP ácido & Metabolic process \\
\hline \multirow[t]{2}{*}{ 34\# } & Venom serine proteinase HS114 & 82233395 & 108.90 & 47 & 15 & Bothrops jararaca & Secretada - SVSP neutro & Proteolysis \\
\hline & $40 \mathrm{~S}$ ribosomal protein $\mathrm{S} 2$ & 71725683 & 84.80 & 34 & 9 & Oxyuranus scutellatus & Citoplasma & Translation \\
\hline \multirow[t]{2}{*}{ 35\# } & Venom serine proteinase HS114 & 82233395 & 145.83 & 47 & 18 & Bothrops jararaca & Secretada - SP neutro & Proteolysis \\
\hline & $40 \mathrm{~S}$ ribosomal protein $\mathrm{S} 2$ & 71725683 & 113.72 & 43 & 11 & Oxyuranus scutellatus & Citoplasma & Translation \\
\hline \multirow[t]{2}{*}{ 36\# } & Venom serine proteinase HS114 & 82233395 & 132.36 & 52 & 10 & Bothrops jararaca & Secretada - SVSP neutro & Proteolysis \\
\hline & Zinc metalloproteinase $\mathrm{BnP} 2$ & 17044592 & 100.38 & 74 & 4 & Bothropoides pauloensis & Secretada - PI & Apoptosis \\
\hline \multirow[t]{3}{*}{ 37\# } & Zinc metalloproteinase $\mathrm{BnP} 2$ & 17044592 & 104.36 & 93 & 7 & Bothropoides pauloensis & Secretada - PI & Apoptosis \\
\hline & Venom serine proteinase HS114 & 82233395 & 102.61 & 30 & 10 & Bothrops jararaca & Secretada - SVSP neutro & Proteolysis \\
\hline & $40 \mathrm{~S}$ ribosomal protein $\mathrm{S} 2$ & 71725683 & 98.77 & 38 & 10 & Oxyuranus scutellatus & Citoplasma & Translation \\
\hline \multirow[t]{2}{*}{ 38\# } & Proteasome subunit alpha type 1 & 197632007 & 123.16 & 48 & 10 & Drosophila melanogaster & Citoplasma & Ubiquitin-dependent protein \\
\hline & $\begin{array}{l}\text { Cysteine rich secretory protein } \mathrm{Ch}- \\
\qquad \mathrm{CRPb}\end{array}$ & 190195307 & 91.16 & 28 & 7 & Deinagkistrodon acutus & Secretada - CRISP & $\begin{array}{c}\text { Catabolic process } \\
-\end{array}$ \\
\hline \multirow[t]{2}{*}{ 39\# } & $\begin{array}{l}\text { Cysteine rich secretory protein Da- } \\
\qquad \mathrm{CRPb}\end{array}$ & 190195339 & 113.66 & 31 & 7 & Deinagkistrodon acutus & Secretada - CRISP & - \\
\hline & Proteasome subunit alpha type-1 & 5101945 & 112.87 & 39 & 6 & Drosophila melanogaster & Citoplasma & $\begin{array}{l}\text { Ubiquitin-dependent protein } \\
\text { catabolic process }\end{array}$ \\
\hline $40 *$ & $\begin{array}{l}\text { Cysteine rich secretory protein Da- } \\
\qquad \mathrm{CRPb}\end{array}$ & 190195339 & 84.00 & 15 & 2 & Deinagkistrodon acutus & Secretada - CRISP & - \\
\hline $41 \#$ & $\begin{array}{c}\text { Gamma-phospholipase A2 } \\
\text { inhibitor }\end{array}$ & 157885068 & 41.96 & 15 & 2 & Bothrops jararaca & Secretada - PLI & $\begin{array}{c}\text { Regulation of phospholipase A2 } \\
\text { activity }\end{array}$ \\
\hline \multirow[t]{2}{*}{ 42\# } & Triosephosphate isomerase & 45382061 & 125.87 & 53 & 14 & Gallus gallus & Citoplasma & Gluconeogenesis, Glycolysis \\
\hline & Zinc metalloproteinase $\mathrm{BnP} 2$ & 17044592 & 94.29 & 74 & 5 & Bothropoides pauloensis & Secretada - PI & Apoptosis \\
\hline
\end{tabular}


APÊNDICE C - Proteínas identificadas de spots específicos de gel 2-DE das glândulas de veneno da serpente Bothrops jararaca no estado ativado 7 dias após a extração de veneno.

\begin{tabular}{|c|c|c|c|c|c|c|c|c|}
\hline $\begin{array}{l}\mathbf{N}^{\circ} \text { Spot } \\
7 \text { dias }\end{array}$ & Proteína & $\begin{array}{l}\text { Número } \\
\text { acesso }\end{array}$ & $\begin{array}{l}\text { Protein } \\
-10 \lg P\end{array}$ & $\begin{array}{c}\text { Cobertura } \\
\%\end{array}$ & Peptídeo & Organismo & Localização Celular & Processo Biológico \\
\hline \multirow[t]{2}{*}{ 43\# } & Zinc metalloproteinase $\mathrm{BnP1}$ & 172044591 & 104.26 & 76 & 8 & Bothropoides pauloensis & Secretada - PI & Apoptosis \\
\hline & $\begin{array}{c}\text { Gamma-phospholipase A2 } \\
\text { inhibitor }\end{array}$ & 157885068 & 103.99 & 47 & 8 & Bothrops jararaca & Secretada - PLI & $\begin{array}{c}\text { Regulation of phospholipase A2 } \\
\text { activity }\end{array}$ \\
\hline 44\# & Zinc metalloproteinase $\mathrm{BnP} 2$ & 17044592 & 73.99 & 32 & 2 & Bothropoides pauloensis & Secretada - PI & Apoptosis \\
\hline 45\# & Zinc metalloproteinase $\mathrm{BnP} 2$ & 17044592 & 162.62 & 93 & 13 & Bothropoides pauloensis & Secretada - PI & Apoptosis \\
\hline 46\# & Zinc metalloproteinase $\mathrm{BnP} 2$ & 17044592 & 136.80 & 84 & 7 & Bothropoides pauloensis & Secretada - PI & Apoptosis \\
\hline \multirow[t]{2}{*}{ 47\# } & Alpha phospholipase A2 inhibitor & 215275475 & 115.93 & 58 & 18 & Bothrops jararaca & Secretada - PLI & $\begin{array}{c}\text { Regulation of phospholipase A2 } \\
\text { activity }\end{array}$ \\
\hline & $\begin{array}{l}\text { Zinc metalloproteinase-disintegrin } \\
\text { BITM06A }\end{array}$ & 82214993 & 107.36 & 29 & 14 & Bothrops insularis & Secretada - PIII & Proteolysis \\
\hline \multirow[t]{2}{*}{ 48\# } & Alpha phospholipase A2 inhibitor & 215275475 & 110.37 & 61 & 18 & Bothrops jararaca & Secretada - PLI & $\begin{array}{c}\text { Regulation of phospholipase } \mathrm{A} 2 \\
\text { activity }\end{array}$ \\
\hline & Zinc metalloproteinase BnP1 & 187608847 & 103.48 & 31 & 11 & Bothropoides pauloensis & Secretada - PI & Apoptosis \\
\hline 49\# & $\begin{array}{c}\text { Alpha-type phospholipase A2 } \\
\text { inhibitor }\end{array}$ & 215275475 & 95.06 & 30 & 3 & Bothrops jararaca & Secretada - PLI & $\begin{array}{c}\text { Regulation of phospholipase A2 } \\
\text { activity }\end{array}$ \\
\hline \multirow[t]{2}{*}{ 50\# } & $\begin{array}{c}\text { Alpha phospholipase A2 inhibitor } \\
\text { precursor }\end{array}$ & 167547111 & 124.34 & 58 & 16 & Bothrops jararaca & Secretada - PLI & $\begin{array}{c}\text { Regulation of phospholipase A2 } \\
\text { activity }\end{array}$ \\
\hline & Zinc metalloproteinase BnP1 & 187608847 & 105.66 & 26 & 9 & Bothropoides pauloensis & Secretada - PI & Apoptosis \\
\hline \multirow[t]{3}{*}{ 51\# } & $\begin{array}{c}\text { Alpha phospholipase A2 inhibitor } \\
\text { precursor }\end{array}$ & 167547111 & 117.24 & 52 & 14 & Bothrops jararaca & Secretada - PLI & $\begin{array}{c}\text { Regulation of phospholipase A2 } \\
\text { activity }\end{array}$ \\
\hline & Zinc metalloproteinase BITM02A & 82214994 & 119.68 & 33 & 12 & Bothrops insularis & Secretada - PI & Proteolysis \\
\hline & Protein disulfide isoemrase & 63146076 & 112.85 & 30 & 9 & Oxyuranus scutellatus & Retículo endoplasmático & $\begin{array}{c}\text { Homeostasis, Metabolic and } \\
\text { Apoptotic process }\end{array}$ \\
\hline \multirow[t]{2}{*}{ 52\# } & Nucleoside diphosphate kinase B & 66864901 & 95.28 & 46 & 9 & Canis lúpus familiaris & Citoplasma & Nucleotide metabolism \\
\hline & Peptidyl-prolyl cis-trans isomerase & 126277042 & 62.62 & 25 & 4 & Crotalus adamanteus & Citoplasma & isomerase \\
\hline
\end{tabular}


APÊNDICE C - Proteínas identificadas de spots específicos de gel 2-DE das glândulas de veneno da serpente Bothrops jararaca no estado ativado 7 dias após a extração de veneno.

\begin{tabular}{|c|c|c|c|c|c|c|c|c|}
\hline $\begin{array}{l}\mathrm{N}^{\circ} \text { Spot } \\
7 \text { dias }\end{array}$ & Proteína & $\begin{array}{l}\text { Número } \\
\text { acesso }\end{array}$ & $\begin{array}{l}\text { Protein } \\
-10 \lg P\end{array}$ & $\begin{array}{c}\text { Cobertura } \\
\%\end{array}$ & Peptídeo & Organismo & Localização Celular & Processo Biológico \\
\hline & B-like & & & & & & & \\
\hline \multirow[t]{2}{*}{$53 *$} & $\begin{array}{l}\text { Zinc metalloproteinase-disintegrin } \\
\text { bothropasin }\end{array}$ & 82190823 & 108.51 & 16 & 7 & Bothrops jararaca & Secretada - PIII & Cell adhesion \\
\hline & Nucleoside diphosphate kinase A & 325197188 & 105.03 & 35 & 5 & Macaca mulatta & Citoplasma & Biosynthetic process \\
\hline \multirow[t]{3}{*}{ 54\# } & C-type lectin & 41353970 & 102.69 & 27 & 4 & Bothrops insularis & Secretada - CTL & Hemagglutinating activity \\
\hline & Bothroinsularin subunit alpha & 229621684 & 77.02 & 23 & 3 & Bothrops insularis & Secretada - CTL & Blood coagulation \\
\hline & Vimentin & 17386168 & 109.02 & 10 & 4 & Daboia russellii & Citoesqueleto & Intermediate filament organization \\
\hline \multirow[t]{3}{*}{ 55\# } & C-type lectin BiL & 82126834 & 136.43 & 47 & 7 & Bothrops insularis & Secretada - CTL & Hemagglutinating activity \\
\hline & Bothroinsularin subunit beta & 229621685 & 120.00 & 34 & 6 & Bothrops insularis & Secretada - CTL & $\begin{array}{c}\text { Blood coagulation cascade } \\
\text { inhibiting }\end{array}$ \\
\hline & Vimentin & 17386168 & 110.72 & 14 & 5 & Daboia russellii & Citoesqueleto & Intermediate filament organization \\
\hline $56 \#$ & C-type lectin BiL & 82126834 & 90.12 & 15 & 3 & Bothrops insularis & Secretada - CTL & Hemagglutinating activity \\
\hline \multirow[t]{2}{*}{ 57\# } & C-type lectin BiL & 82126834 & 196.16 & 83 & 30 & Bothrops insularis & Secretada - CTL & Hemagglutinating activity \\
\hline & Galactose-specific lectin & 34922459 & 175.28 & 78 & 23 & Bothrops jararacussu & Secretada - CTL & Hemagglutinating activity \\
\hline \multirow[t]{2}{*}{ 58\# } & C-type lectin BiL & 82126834 & 157.25 & 72 & 16 & Bothrops insularis & Secretada - CTL & Hemagglutinating activity \\
\hline & L-amino acid oxidase precursor & 195927838 & 100.97 & 12 & 5 & Bothropoides pauloensis & Secretada - LAAO & Apoptosis, Cytolysis, Hemolysis \\
\hline \multirow[t]{2}{*}{ 59\# } & C-type lectin BiL & 82126834 & 205.49 & 85 & 32 & Bothrops insularis & Secretada - CTL & Hemagglutinating activity \\
\hline & Galactose-specific lectin & 34922459 & 182.64 & 89 & 24 & Bothrops jararacussu & Secretada - CTL & Hemagglutinating activity \\
\hline \multirow[t]{2}{*}{ 60\# } & Disintegrin & 29501768 & 88.58 & 74 & 5 & Bothrops alternatus & Secretada & Cell adhesion \\
\hline & Bothroinsularin subunit beta & 229621685 & 88.42 & 49 & 4 & Bothrops insularis & Secretada - CTL & $\begin{array}{l}\text { Blood coagulation cascade } \\
\text { inhibiting }\end{array}$ \\
\hline 61\# & Disintegrin & 29501768 & 102.09 & 78 & 8 & Bothrops alternatus & Secretada & Cell adhesion \\
\hline \multirow[t]{2}{*}{ 62\# } & C-type lectin BiL & 41353970 & 160.56 & 72 & 19 & Bothrops insularis & Secretada - CTL & Hemagglutinating activity \\
\hline & Bothroinsularin subunit beta & 229621685 & 145.66 & 47 & 6 & Bothrops insularis & Secretada - CTL & $\begin{array}{c}\text { Blood coagulation cascade } \\
\text { inhibiting }\end{array}$ \\
\hline
\end{tabular}


APÊNDICE C - Proteínas identificadas de spots específicos de gel 2-DE das glândulas de veneno da serpente Bothrops jararaca no estado ativado 7 dias após a extração de veneno.

\begin{tabular}{|c|c|c|c|c|c|c|c|c|}
\hline $\begin{array}{l}N^{\circ} \text { Spot } \\
7 \text { dias }\end{array}$ & Proteína & $\begin{array}{l}\text { Número } \\
\text { acesso }\end{array}$ & $\begin{array}{l}\text { Protein } \\
-10 \lg P\end{array}$ & $\begin{array}{c}\text { Cobertura } \\
\%\end{array}$ & Peptídeo & Organismo & Localização Celular & Processo Biológico \\
\hline 63\# & Thioredoxin & 20140734 & 52.27 & 17 & 2 & Ophiophagus hannah & Citoplasma & Cell redox homeostasis \\
\hline \multirow[t]{2}{*}{ 64\# } & $\begin{array}{l}\text { Snake venom vascular endothelial } \\
\text { growth factor toxin }\end{array}$ & 48428663 & 95.91 & 36 & 8 & Bothrops jararaca & Secretada - svVEGF & Angiogenesis/Differentiation \\
\hline & Thioredoxin & 20140734 & 88.73 & 43 & 6 & Ophiophagus hannah & Citoplasma & Cell redox homeostasis \\
\hline 65\# & Thioredoxin & 20140734 & 119.00 & 59 & 18 & Ophiophagus hannah & Citoplasma & Cell redox homeostasis \\
\hline 66\# & Ribosomal protein S14 & 5441520 & 86.81 & 43 & 3 & Canis lupus & Citoplasma & Translation \\
\hline \multirow[t]{2}{*}{ 67\# } & C-type lectin & 338855286 & 74.06 & 22 & 7 & Crotalus adamanteus & Secretada - CTL & Carbohydrate binding \\
\hline & Cytochrome c & 119388033 & 86.94 & 38 & 4 & Crotalus adamanteus & Mitocôndria & Electron transport \\
\hline \multirow[t]{2}{*}{ 68\# } & Cytochrome c & 119388033 & 76.75 & 17 & 2 & Crotalus adamanteus & Mitocôndria & Electron transport \\
\hline & Thioredoxin & 20140734 & 59.80 & 23 & 2 & Ophiophagus hannah & Citoplasma & Cell redox homeostasis \\
\hline
\end{tabular}

Nota: (*) Dados obtidos no banco de dados Metazoa nr 19082011 e Proteopeptidome_NCBInr_29042012 do MALDI-TOF/TOF

(\#) Dados obtidos no banco de dados Metazoa nr 19082011 e Proteopeptidome_NCBInr_29042012 do Orbitrap

Retículo endoplasmático (ER), Lectinas tipo C (CTL), Serinoproteinases (SVSP), Proteínas secretadas ricas em cisteína (CRISP), Classes de Metaloproteinases (PI, PII, PIII), L-aminoácido oxidase (LAAO), Inibidores de Fosfolipases A2 (PLI), Fator de crescimento do endotélio vascular de serpente (svVEGF). 
APÊNDICE D 
APÊNDICE D - Proteínas identificadas de spots específicos de gel 2-DE das glândulas de veneno da serpente Bothrops jararaca tratadas com reserpina durante 4 dias.

\begin{tabular}{|c|c|c|c|c|c|c|c|c|}
\hline $\begin{array}{l}\mathbf{N}^{\circ} \text { Spot } \\
\text { Res 4d }\end{array}$ & Proteína & $\begin{array}{l}\text { Número } \\
\text { acesso }\end{array}$ & $\begin{array}{l}\text { Proteína } \\
\text {-10lgP }\end{array}$ & $\begin{array}{c}\text { Cobertura } \\
\%\end{array}$ & Peptídeo & Organismo & Localização Celular & Processo Biológico \\
\hline 1\# & Endoplasmin-like & 327272356 & 97.66 & 27 & 5 & Anolis carolinensis & Retículo endoplasmático & Stress response \\
\hline $2^{*}$ & Calreticulin-like & 326935595 & 69.72 & 15 & 4 & Meleagris gallopavo & Retículo endoplasmático & Protein folding \\
\hline 3\# & PDI & 63146076 & 247.39 & 14 & 8 & Oxyuranus scutellatus & Retículo endoplasmático & $\begin{array}{c}\text { Homeostasis, Metabolic and } \\
\text { apoptotic process }\end{array}$ \\
\hline \multirow[t]{2}{*}{ 4\# } & PDI & 63146076 & 114.47 & 40 & 16 & Oxyuranus scutellatus & Retículo endoplasmático & $\begin{array}{c}\text { Homeostasis, Metabolic and } \\
\text { apoptotic process }\end{array}$ \\
\hline & Batroxstatin-1 & 205278803 & 96.30 & 42 & 14 & Bothrops jararaca & Secretada - PIII & $\begin{array}{c}\text { Apoptosis, Cell adhesion, } \\
\text { proteolysis }\end{array}$ \\
\hline \multirow[t]{2}{*}{ 5\# } & Protein disulfide isomerase family A3 & 148226947 & 177.80 & 58 & 14 & Xenopus laevis & Retículo endoplasmático & $\begin{array}{c}\text { Homeostasis, Metabolic and } \\
\text { apoptotic process }\end{array}$ \\
\hline & L-amino acid oxidase precursor & 195927838 & 121.36 & 18 & 6 & Bothropoides pauloensis & Secretada - LAAO & Apoptosis, Cytolysis, Hemolysis \\
\hline \multirow[t]{3}{*}{ 6\# } & $\begin{array}{l}\text { Protein disulfide isomerase family A3 } \\
\text { precursor }\end{array}$ & 45383890 & 117.42 & 33 & 4 & Gallus gallus & Retículo endoplasmático & $\begin{array}{l}\text { Homeostasis, Metabolic and } \\
\text { apoptotic process }\end{array}$ \\
\hline & L-amino acid oxidase precursor & 195927838 & 129.75 & 25 & 9 & Bothropoides pauloensis & Secretada - LAAO & Apoptosis, Cytolysis, Hemolysis \\
\hline & $\begin{array}{l}\text { Zinc metalloproteinase-disintegrin } \\
\text { jararhagin }\end{array}$ & 231997 & 112.74 & 17 & 11 & Bothrops jararaca & Secretada - PIII & $\begin{array}{l}\text { Apoptosis, Cell adhesion, } \\
\text { Inflammatory response }\end{array}$ \\
\hline \multirow[t]{2}{*}{$7 *$} & $\begin{array}{l}\text { Protein disulfide isomerase associated } \\
\qquad 3 \text { precursor }\end{array}$ & 148226947 & 84.46 & 19 & 7 & Xenopus laevis & $\begin{array}{l}\text { Retículo endoplasmático } \\
\text { Secretada - LAAO }\end{array}$ & $\begin{array}{c}\text { Homeostasis, Metabolic and } \\
\text { apoptotic process }\end{array}$ \\
\hline & L-amino acid oxidase & 195927838 & 84.64 & 18 & 6 & Bothropoides pauloensis & & Apoptosis, Cytolysis, Hemolysis \\
\hline \multirow[t]{2}{*}{$8^{*}$} & $\begin{array}{l}\text { Protein disulfide isomerase associated } \\
\qquad 3 \text { precursor }\end{array}$ & 148226947 & 81.00 & 20 & 2 & Xenopus laevis & Retículo endoplasmático & $\begin{array}{c}\text { Homeostasis, Metabolic and } \\
\text { apoptotic process }\end{array}$ \\
\hline & L-amino acid oxidase & 195927838 & 129.38 & 14 & 7 & Bothropoides pauloensis & Secretada - LAAO & Apoptosis, Cytolysis, Hemolysis \\
\hline 9\# & L-amino acid oxidase & 82127389 & 85.42 & 16 & 5 & Bothrops moojeni & Secretada - LAAO & Apoptosis, Cytolysis, Hemolysis \\
\hline \multirow[t]{2}{*}{ 10\# } & Alpha enolase & 5305427 & 124.23 & 14 & 4 & Python regius & Citoplasma & Glycolysis \\
\hline & Enolase 3, beta muscle & 56206030 & 107.45 & 36 & 2 & Mus musculus & Citoplasma & Glycolysis \\
\hline
\end{tabular}


APÊNDICE D - Proteínas identificadas de spots específicos de gel 2-DE das glândulas de veneno da serpente Bothrops jararaca tratadas com reserpina durante 4 dias.

\begin{tabular}{|c|c|c|c|c|c|c|c|c|}
\hline $\begin{array}{l}\mathbf{N}^{0} \text { Spot } \\
\text { Res 4d }\end{array}$ & Proteína & $\begin{array}{l}\text { Número } \\
\text { acesso }\end{array}$ & $\begin{array}{c}\text { Proteína } \\
\text {-10lgP }\end{array}$ & $\begin{array}{c}\text { Cobertura } \\
\%\end{array}$ & Peptídeo & Organismo & Localização Celular & Processo Biológico \\
\hline \multirow[t]{2}{*}{ 11\# } & $\begin{array}{l}\text { Zinc metalloproteinase-disintegrin } \\
\text { batroxstatin-2 }\end{array}$ & 395455159 & 108.01 & 39 & 11 & Bothrops atrox & Secretada - PIII & $\begin{array}{c}\text { Apoptosis, Cell adhesion, } \\
\text { proteolysis }\end{array}$ \\
\hline & ATP synthase alpha subunit & 118562410 & 95.52 & 25 & 4 & Elaphe quadrivirgata & Mitocôndria & ATP synthesis, Transport \\
\hline 12\# & ATP synthase alpha subunit & 118562410 & 93.19 & 23 & 2 & Elaphe quadrivirgata & Mitocôndria & ATP synthesis, Transport \\
\hline \multirow[t]{2}{*}{ 13\# } & $\begin{array}{l}\text { Zinc metalloproteinase-disintegrin } \\
\text { batroxstatin-2 }\end{array}$ & 395455159 & 134.33 & 39 & 9 & Bothrops atrox & Secretada - PIII & $\begin{array}{c}\text { Apoptosis, Cell adhesion, } \\
\text { proteolysis }\end{array}$ \\
\hline & ATP synthase alpha subunit & 118562410 & 102.80 & 25 & 4 & Elaphe quadrivirgata & Mitocôndria & ATP synthesis, Transport \\
\hline \multirow[t]{2}{*}{ 14\# } & $\begin{array}{l}\text { Zinc metalloproteinase-disintegrin } \\
\text { batroxstatin- } 2\end{array}$ & 395455159 & 97.49 & 25 & 6 & Bothrops atrox & Secretada - PIII & $\begin{array}{c}\text { Apoptosis, Cell adhesion, } \\
\text { proteolysis }\end{array}$ \\
\hline & ATP synthase alpha subunit & 118562410 & 104.71 & 26 & 4 & Elaphe quadrivirgata & Mitocôndria & ATP synthesis, Transport \\
\hline \multirow[t]{2}{*}{ 15\# } & Beta actin & 58198383 & 139.00 & 25 & 4 & Pseudonaja textilis & Citoplasma & Structural element organization \\
\hline & Actin, alpha skeletal muscle & 67462115 & 131.05 & 16 & 5 & Atractaspis microlepidota & Citoplasma & Skeletal muscle fiber development \\
\hline \multirow[t]{2}{*}{ 16\# } & Beta actin & 58198383 & 166.55 & 25 & 4 & Pseudonaja textilis & Citoplasma & Structural element organization \\
\hline & Alpha actin & 15825436 & 164.92 & 16 & 4 & Atractaspis microlepidota & Citoplasma & Structural element organization \\
\hline \multirow[t]{2}{*}{$17 *$} & $\begin{array}{c}\text { Isocitrate dehydrogenase [NADP] } \\
\text { Citoplasmic-like }\end{array}$ & 327270553 & 95.08 & 29 & 7 & Anolis carolinensis & Citoplasma & Isocitrate metabolic process \\
\hline & $\begin{array}{l}\text { Medium-chain specific acyl-CoA } \\
\text { dehydrogenase, mitochondrial-like }\end{array}$ & 327276681 & 120.04 & 40 & 6 & Anolis carolinensis & Mitocôndria & Lipid metabolism \\
\hline 18\# & Protein disulfide isomerase & 63146076 & 123.42 & 13 & 7 & Oxyuranus scutellatus & Retículo endoplasmático & $\begin{array}{c}\text { Homeostasis, Metabolic and } \\
\text { apoptotic process }\end{array}$ \\
\hline \multirow[t]{2}{*}{$19 *$} & Actin, alpha skeletal muscle & 67462115 & 77.93 & 19 & 6 & Atractaspis microlepidota & Citoplasma & Skeletal muscle fiber development \\
\hline & Beta actin & 296434064 & 65.38 & 13 & 4 & Gloydius brevicaudus & Citoplasma & Structural element organization \\
\hline 20\# & Venom metalloproteinase jararin & 87245249 & 104.41 & 38 & 7 & Bothrops jararaca & Secretada - PII & Cell adhesion \\
\hline $21 *$ & Annexin A2 & 168983833 & 126.06 & 19 & 3 & Mus musculus & Secretada & Fibrinolysis \\
\hline $22 *$ & Annexin A2 & 168983833 & 125.26 & 19 & 3 & Mus musculus & Secretada & Fibrinolysis \\
\hline $23 *$ & Glyceraldehyde-3-phosphate & 160385820 & 59.90 & 13 & 2 & Mustela putorius furo & Citoplasma & Glycolysis \\
\hline
\end{tabular}


APÊNDICE D - Proteínas identificadas de spots específicos de gel 2-DE das glândulas de veneno da serpente Bothrops jararaca tratadas com reserpina durante 4 dias.

\begin{tabular}{|c|c|c|c|c|c|c|c|c|}
\hline $\begin{array}{l}\mathbf{N}^{\circ} \text { Spot } \\
\text { Res 4d }\end{array}$ & Proteína & $\begin{array}{l}\text { Número } \\
\text { acesso }\end{array}$ & $\begin{array}{c}\text { Proteína } \\
-10 \lg P\end{array}$ & $\begin{array}{c}\text { Cobertura } \\
\%\end{array}$ & Peptídeo & Organismo & Localização Celular & Processo Biológico \\
\hline & dehydrogenase & & & & & & & \\
\hline 24\# & Platelet aggregating serine peptidase & 34148047 & 95.41 & 33 & 10 & Bothrops jararaca & Secretada - SVSP ácido & Proteolysis \\
\hline \multirow[t]{2}{*}{$25^{*}$} & Venom serine proteinase HS114 & 82233395 & 167.57 & 60 & 20 & Bothrops jararaca & Secretada - SVSP ácido & Proteolysis \\
\hline & Tropomyosin beta chain-like isoform 1 & 348570236 & 138.16 & 35 & 12 & Cavia porcellus & Citoplasma & Muscle contraction \\
\hline \multirow[t]{3}{*}{$26 *$} & Venom serine proteinase HS114 & 82233395 & 211.54 & 68 & 46 & Bothrops jararaca & Secretada - SVSP ácido & Proteolysis \\
\hline & Tropomyosin beta chain-like isoform 1 & 348570236 & 138.88 & 35 & 9 & Cavia porcellus & Citoplasma & Muscle contraction \\
\hline & PDI & 63146076 & 131.95 & 23 & 12 & Oxyuranus scutellatus & Retículo endoplasmático & $\begin{array}{c}\text { Homeostasis, Metabolic and } \\
\text { apoptotic process }\end{array}$ \\
\hline $27 *$ & Venom serine proteinase HS114 & 82233395 & 116.50 & 27 & 4 & Bothrops jararaca & Secretada - SVSP ácido & Proteolysis \\
\hline 28\# & Venom serine proteinase HS114 & 82233395 & 200.07 & 36 & 7 & Bothrops jararaca & Secretada - SVSP ácido & Proteolysis \\
\hline 29\# & Venom serine proteinase HS114 & 82233395 & 105.76 & 34 & 7 & Bothrops jararaca & Secretada - SVSP ácido & Proteolysis \\
\hline \multirow[t]{2}{*}{ 30\# } & Venom serine proteinase HS114 & 82233395 & 150.69 & 56 & 17 & Bothrops jararaca & Secretada - SVSP ácido & Proteolysis \\
\hline & Alpha actin & 52078484 & 100.07 & 32 & 6 & Oxyuranus scutellatus & Citoplasma & Structural element organization \\
\hline \multirow[t]{2}{*}{ 31\# } & Venom serine proteinase HS114 & 82233395 & 172.75 & 69 & 26 & Bothrops jararaca & Secretada - SVSP ácido & Proteolysis \\
\hline & Beta actin & 52078486 & 111.30 & 35 & 6 & Oxyuranus scutellatus & Citoplasma & Structural element organization \\
\hline $32 *$ & Lipocortin V & 2981437 & 48.20 & 11 & 2 & Rattus novergicus & Citoplasma & Blood coagulation, Hemostasis \\
\hline $33 *$ & Annexin 5 & 224049201 & 76.31 & 11 & 2 & Taeniopygia guttata & Citoplasma & Blood coagulation, Hemostasis \\
\hline \multirow[t]{2}{*}{$34^{*}$} & Annexin A5-like & 327274168 & 52.23 & 16 & 2 & Anolis carolinensis & Citoplasma & Blood coagulation, Hemostasis \\
\hline & 40S ribosomal protein $\mathrm{S} 2$ & 71725683 & 50.06 & 16 & 2 & Oxyuranus scutellatus & Citoplasma & Translation \\
\hline $35 *$ & Annexin A5-like & 327274168 & 52.18 & 13 & 2 & Anolis carolinensis & Citoplasma & Blood coagulation, Hemostasis \\
\hline $36 *$ & $\begin{array}{l}\text { Cysteine rich secretory protein Da- } \\
\qquad \mathrm{CRPb}\end{array}$ & 190195339 & 107.92 & 23 & 4 & Deinagkistrodon acutus & Secretada - CRISP & - \\
\hline $37 *$ & $\begin{array}{l}\text { Cysteine rich secretory protein } \mathrm{Ch}- \\
\text { CRPIb }\end{array}$ & 190195315 & 107.72 & 23 & 4 & Crotalus horridus & Secretada - CRISP & - \\
\hline 38* & $\begin{array}{l}\text { Voltage-dependent anion selective } \\
\text { channel } 2\end{array}$ & 296439786 & 98.47 & 30 & 2 & Mesocricetus auratus & Mitocôndria & Ion transport \\
\hline
\end{tabular}


APÊNDICE D - Proteínas identificadas de spots específicos de gel 2-DE das glândulas de veneno da serpente Bothrops jararaca tratadas com reserpina durante 4 dias.

\begin{tabular}{|c|c|c|c|c|c|c|c|c|}
\hline $\begin{array}{l}\mathbf{N}^{0} \text { Spot } \\
\text { Res 4d }\end{array}$ & Proteína & $\begin{array}{l}\text { Número } \\
\text { acesso }\end{array}$ & $\begin{array}{c}\text { Proteína } \\
\text {-10lgP }\end{array}$ & $\begin{array}{c}\text { Cobertura } \\
\%\end{array}$ & Peptídeo & Organismo & Localização Celular & Processo Biológico \\
\hline \multirow[t]{2}{*}{$39 *$} & 14-3-3 protein epsilon & 209156034 & 98.15 & 47 & 9 & Salmo salar & Citoplasma & Protein targeting \\
\hline & $\begin{array}{l}\text { Tropomyosin beta chain isoform } 1 \text {, } \\
\text { partial }\end{array}$ & 380793471 & 87.62 & 14 & 3 & Macaca mulatta & Citoplasma & Muscle contraction \\
\hline 40\# & $\begin{array}{l}\text { Tropomyosin beta chain isoform } 1 \text {, } \\
\text { partial }\end{array}$ & 380793471 & 82.02 & 11 & 3 & Macaca mulatta & Citoplasma & Muscle contraction \\
\hline 41\# & $\begin{array}{l}\text { Tyrosine 3-monooxygenase/tryptophan } \\
\text { 5-monooxigenase activation protein } \\
\text { epsilon polypeptide }\end{array}$ & 224076320 & 89.16 & 34 & 5 & Taeniopygia guttata & Mitocôndria & Protein targeting to mitochondria \\
\hline \multirow[t]{3}{*}{$42 \#$} & $\begin{array}{l}\text { Tyrosine 3-monooxygenase/tryptophan } \\
\text { 5-monooxigenase activation protein, } \\
\text { epsilon polypeptide }\end{array}$ & 224076320 & 75.63 & 26 & 3 & Taeniopygia guttata & Mitocôndria & Protein targeting to mitochondria \\
\hline & $\begin{array}{l}\text { Mitochondrial ATP synthase subunit } \\
\text { beta }\end{array}$ & 323650230 & 48.43 & 14 & 2 & Perca flavescens & Mitocôndria & ATP synthesis, Transport \\
\hline & Actin, alpha skeletal muscle & 67462115 & 144.81 & 27 & 8 & Atractaspis microlepidota & Citoplasma & Skeletal muscle fiber development \\
\hline 43\# & Serine proteinase & 76365438 & 70.04 & 18 & 5 & Crotalus durissus & Secretada - SVSP neutro & Proteolysis \\
\hline \multirow[t]{2}{*}{ 44\# } & Plasminogen activator Haly-PA & 156630858 & 115.18 & 21 & 11 & Gloydius brevicaudus & Secretada - SVSP neutro & $\begin{array}{c}\text { Proteolysis, Regulation blood } \\
\text { pressure }\end{array}$ \\
\hline & Serine proteinase & 123895843 & 87.45 & 24 & 7 & Crotalus durissus & Secretada - SVSP neutro & Proteolysis \\
\hline $45^{*}$ & Calbidin D28k & 55003506 & 96.5 & & 4 & Sorghum bicolor & Citoplasma & $\begin{array}{l}\text { Calcium ion transport, } \\
\text { homeostasis }\end{array}$ \\
\hline 46\# & Metalloproteinase jararafibrase-2 & 82219563 & 94.29 & 9 & 5 & Bothrops jararaca & Secretada - PII & Cell adhesion \\
\hline \multirow[t]{2}{*}{ 47\# } & Metalloproteinase jararafibrase- 2 & 82219563 & 89.74 & 11 & 6 & Bothrops jararaca & Secretada - PII & Cell adhesion \\
\hline & Rho GDP dissociation inhibitor alpha & 61553152 & 47.67 & 16 & 2 & Bos taurus & Citoplasma & Regulation GTPase activity \\
\hline \multirow[t]{3}{*}{ 48\# } & Metalloproteinase jararafibrase- 2 & 82219563 & 123.90 & 22 & 15 & Bothrops jararaca & Secretada - PII & Cell adhesion \\
\hline & Beta actin & 52078486 & 98.42 & 35 & 5 & Oxyuranus scutellatus & Citoplasma & Structural element organization \\
\hline & Rho GDP dissociation inhibitor alpha & 61553152 & 43.10 & 21 & 2 & Bos taurus & Citoplasma & Regulation GTPase activity \\
\hline
\end{tabular}


APÊNDICE D - Proteínas identificadas de spots específicos de gel 2-DE das glândulas de veneno da serpente Bothrops jararaca tratadas com reserpina durante 4 dias.

\begin{tabular}{|c|c|c|c|c|c|c|c|c|}
\hline $\begin{array}{l}\mathbf{N}^{0} \text { Spot } \\
\text { Res } 4 d\end{array}$ & Proteína & $\begin{array}{l}\text { Número } \\
\text { acesso }\end{array}$ & $\begin{array}{c}\text { Proteína } \\
-10 \lg P\end{array}$ & $\begin{array}{c}\text { Cobertura } \\
\%\end{array}$ & Peptídeo & Organismo & Localização Celular & Processo Biológico \\
\hline 49\# & Gamma-phospholipase A2 inhibitor & 157885066 & 87.00 & 28 & 4 & Bothrops jararaca & Secretada - PLI & $\begin{array}{c}\text { Regulation of phospholipase } \mathrm{A} 2 \\
\text { activity }\end{array}$ \\
\hline 50\# & Zinc metalloproteinase BnP1 & 172044591 & 87.95 & 47 & 5 & Bothropoides pauloensis & Secretada - PI & Apoptosis \\
\hline 51\# & Zinc metalloproteinase BnP2 & 172044592 & 96.64 & 32 & 2 & Bothropoides pauloensis & Secretada - PI & Apoptosis \\
\hline $52 *$ & $\begin{array}{c}\text { Sticholysin-2 } \\
\text { Metalloproteinase jararafibrase-2 }\end{array}$ & $\begin{array}{r}2815496 \\
82219563\end{array}$ & $\begin{array}{l}53.76 \\
62.02\end{array}$ & $\begin{array}{l}35 \\
19\end{array}$ & $\begin{array}{l}3 \\
4\end{array}$ & $\begin{array}{l}\text { Stoichactis helianthus } \\
\text { Bothrops jararaca }\end{array}$ & $\begin{array}{c}\text { Secretada } \\
\text { Secretada - PII }\end{array}$ & $\begin{array}{c}\text { Cytolysis, Hemolysis, Ion } \\
\text { transport } \\
\text { Cell adhesion }\end{array}$ \\
\hline $53 *$ & Metalloproteinase jararafibrase-2 & 82219563 & 176.97 & 33 & 27 & Bothrops jararaca & Secretada - PII & Cell adhesion \\
\hline 54\# & Metalloproteinase jararafibrase-2 & 82219563 & 183.25 & 28 & 35 & Bothrops jararaca & Secretada - PII & Cell adhesion \\
\hline 55\# & $\begin{array}{l}\text { Gluthatione S-transferase pi 1-like } \\
\text { Metalloproteinase jararafibrase-2 }\end{array}$ & $\begin{array}{c}327260614 \\
82219563\end{array}$ & $\begin{array}{l}152.20 \\
120.51\end{array}$ & $\begin{array}{l}45 \\
22\end{array}$ & $\begin{array}{c}8 \\
14\end{array}$ & $\begin{array}{l}\text { Anolis carolinensis } \\
\text { Bothrops jararaca }\end{array}$ & $\begin{array}{c}\text { Citoplasma } \\
\text { Secretada - PII }\end{array}$ & $\begin{array}{l}\text { Gluthatione metabolic process } \\
\text { Cell adhesion }\end{array}$ \\
\hline 56\# & $\begin{array}{l}\text { Gluthatione S-transferase pi 1-like } \\
\text { Metalloproteinase jararafibrase-2 }\end{array}$ & $\begin{array}{l}327260614 \\
82219563\end{array}$ & $\begin{array}{l}205.97 \\
155.93\end{array}$ & $\begin{array}{l}57 \\
23\end{array}$ & $\begin{array}{l}21 \\
16\end{array}$ & $\begin{array}{l}\text { Anolis carolinensis } \\
\text { Bothrops jararaca }\end{array}$ & $\begin{array}{c}\text { Citoplasma } \\
\text { Secretada - PII }\end{array}$ & $\begin{array}{l}\text { Gluthatione metabolic process } \\
\text { Cell adhesion }\end{array}$ \\
\hline $57 *$ & $\begin{array}{l}\text { Putative proteasome subunit alpha type } \\
2\end{array}$ & 224045021 & 68.16 & 41 & 3 & Taeniopygia guttata & Citoplasma & $\begin{array}{l}\text { Ubiquitin-dependent protein } \\
\text { catabolic process }\end{array}$ \\
\hline $58 *$ & Gluthatione S-transferase Mu 1-like & 327270920 & 111.84 & 36 & 8 & Anolis carolinensis & Citoplasma & Gluthatione metabolic process \\
\hline 59* & Zinc metalloproteinase $\mathrm{BnP} 2$ & 172044592 & 96.40 & 51 & 3 & Bothropoides pauloensis & Secretada - PI & Apoptosis \\
\hline 60\# & Zinc metalloproteinase BITM02A & 82214994 & 81.25 & 15 & 3 & Bothrops jararaca & Secretada - PI & $\begin{array}{l}\text { Negative regulation of } \\
\text { transcription }\end{array}$ \\
\hline 61\# & $\begin{array}{c}\text { Myosin light polypeptide 6-like } \\
\text { isoform } 2\end{array}$ & 335288113 & 49.96 & 23 & 2 & Sus scrofa & Citoplasma & Muscle contraction \\
\hline 62\# & Myosin light chain & DV556847 & 141.13 & 27 & 5 & Deinagkistrodon acutus & Citoplasma & Muscle contraction \\
\hline 63\# & Actin, alpha skeletal muscle & 67462115 & 67.15 & 8 & 3 & Atractaspis microlepidota & Citoplasma & Skeletal muscle fiber development \\
\hline 64\# & Sticholysin-2 & 2815496 & 64.19 & 58 & 3 & Stoichactis helianthus & Secretada & Cytolysis, Ion transport \\
\hline $65 \#$ & $\begin{array}{l}\text { Zinc metalloproteinase-disintegrin } \\
\text { jararhagin }\end{array}$ & 231997 & 94.00 & 23 & 12 & Bothrops jararaca & Secretada - PIII & $\begin{array}{l}\text { Apoptosis, Cell adhesion, } \\
\text { Inflammatory response }\end{array}$ \\
\hline
\end{tabular}


APÊNDICE D - Proteínas identificadas de spots específicos de gel 2-DE das glândulas de veneno da serpente Bothrops jararaca tratadas com reserpina durante 4 dias.

\begin{tabular}{|c|c|c|c|c|c|c|c|c|}
\hline $\begin{array}{l}\mathbf{N}^{0} \text { Spot } \\
\text { Res 4d }\end{array}$ & Proteína & $\begin{array}{l}\text { Número } \\
\text { acesso }\end{array}$ & $\begin{array}{c}\text { Proteína } \\
-10 \lg P\end{array}$ & $\begin{array}{c}\text { Cobertura } \\
\%\end{array}$ & Peptídeo & Organismo & Localização Celular & Processo Biológico \\
\hline & Alpha-type phospholipase A2 inhibitor & 215275475 & 83.64 & 48 & 9 & Bothrops jararaca & Secretada - PLI & $\begin{array}{c}\text { Regulation of phospholipase A2 } \\
\text { activity }\end{array}$ \\
\hline \multirow[t]{2}{*}{ 66\# } & $\begin{array}{l}\text { ATP synthase subunit d, mitochondrial } \\
\text { isoform } 1\end{array}$ & 118099965 & 136.34 & 46 & 7 & Gallus gallus & Mitocôndria & ATP synthesis, Transport \\
\hline & Alpha-type phospholipase A2 inhibitor & 215275475 & 100.15 & 22 & 4 & Bothrops jararaca & Secretada - PLI & $\begin{array}{c}\text { Regulation of phospholipase A2 } \\
\text { activity }\end{array}$ \\
\hline $67 *$ & Alpha-type phospholipase A2 inhibitor & 215275475 & 91.46 & 22 & 3 & Bothrops jararaca & Secretada - PLI & $\begin{array}{c}\text { Regulation of phospholipase A2 } \\
\text { activity }\end{array}$ \\
\hline 68* & Alpha-type phospholipase A2 inhibitor & 167547111 & 65.99 & 30 & 3 & Bothrops jararaca & Secretada - PLI & $\begin{array}{c}\text { Regulation of phospholipase A2 } \\
\text { activity }\end{array}$ \\
\hline 69\# & DJ-1 & 66267686 & 66.52 & 33 & 4 & Crocodylus niloticus & Citoplasma & \\
\hline \multirow[t]{2}{*}{ 70\# } & Myosin light chain & 52078482 & 143.72 & 37 & 8 & Oxyuranus scutellatus & Citoplasma & Muscle contraction \\
\hline & Calcium-binding protein $\mathrm{p} 22$ & 56118996 & 55.79 & 36 & 3 & Gallus gallus & Citoplasma & Differentiation \\
\hline 71* & $\begin{array}{c}\text { Translocon-associated protein-like } \\
\text { protein }\end{array}$ & 71725701 & 157.41 & 27 & 3 & Oxyuranus scutellatus & Retículo endoplasmático & $\begin{array}{c}\text { Cotranslational protein targeting } \\
\text { to Membrane }\end{array}$ \\
\hline 72\# & Nucleoside diphosphate kinase B & 325197199 & 59.81 & 36 & 4 & Macaca mulatta & Citoplasma & Differentiation, Endocytosis \\
\hline 73* & Glycoprotein IB-binding protein $\alpha$ & 82116886 & 128.80 & 35 & 4 & Bothrops jararaca & Secretada-CTL & $\begin{array}{l}\text { Hemostasis impairing toxin, } \\
\text { Platelet aggregation inhibiting } \\
\text { toxin }\end{array}$ \\
\hline \multirow[t]{2}{*}{ 74\# } & Glycoprotein IB-binding protein $\alpha$ & 82116886 & 77.26 & 32 & 4 & Bothrops jararaca & Secretada - CTL & $\begin{array}{l}\text { Hemostasis impairing toxin, } \\
\text { Platelet aggregation inhibiting }\end{array}$ \\
\hline & ATP synthase alpha subunit & 118562410 & 112.65 & 25 & 4 & Elaphe quadrivirgata & Mitocôndria & $\begin{array}{c}\text { toxin } \\
\text { ATP synthesis, Transport }\end{array}$ \\
\hline $75 *$ & Glycoprotein IB-binding protein $\alpha$ & 82116886 & 106.67 & 25 & 3 & Bothrops jararaca & Secretada - CTL & $\begin{array}{l}\text { Hemostasis impairing toxin, } \\
\text { Platelet aggregation inhibiting } \\
\text { toxin }\end{array}$ \\
\hline
\end{tabular}


APÊNDICE D - Proteínas identificadas de spots específicos de gel 2-DE das glândulas de veneno da serpente Bothrops jararaca tratadas com reserpina durante 4 dias.

\begin{tabular}{|c|c|c|c|c|c|c|c|c|}
\hline $\begin{array}{l}\mathbf{N}^{0} \text { Spot } \\
\text { Res 4d }\end{array}$ & Proteína & $\begin{array}{l}\text { Número } \\
\text { acesso }\end{array}$ & $\begin{array}{l}\text { Proteína } \\
-10 \lg P\end{array}$ & $\begin{array}{c}\text { Cobertura } \\
\%\end{array}$ & Peptídeo & Organismo & Localização Celular & Processo Biológico \\
\hline $76^{*}$ & Glycoprotein IB-binding protein $\alpha$ & 82116886 & 137.11 & 25 & 3 & Bothrops jararaca & Secretada-CTL & $\begin{array}{c}\text { Hemostasis impairing toxin, } \\
\text { Platelet aggregation inhibiting } \\
\text { toxin }\end{array}$ \\
\hline $77 *$ & Glycoprotein IB-binding protein $\alpha$ & 82116886 & 75.32 & 25 & 2 & Bothrops jararaca & Secretada - CTL & $\begin{array}{l}\text { Hemostasis impairing toxin, } \\
\text { Platelet aggregation inhibiting } \\
\text { toxin }\end{array}$ \\
\hline 78* & Cofilin-1 & 51592135 & 108.94 & 27 & 3 & Sus scrofa & Citoplasma & Actin filament organization \\
\hline 79* & Glycoprotein IB-binding protein $\alpha$ & 82116886 & 83.2 & 15 & 2 & Bothrops jararaca & Secretada-CTL & $\begin{array}{l}\text { Hemostasis impairing toxin, } \\
\text { Platelet aggregation inhibiting } \\
\text { toxin }\end{array}$ \\
\hline $80 *$ & Glycoprotein IB-binding protein $\alpha$ & 82116886 & 83.8 & 15 & 2 & Bothrops jararaca & Secretada - CTL & $\begin{array}{l}\text { Hemostasis impairing toxin, } \\
\text { Platelet aggregation inhibiting } \\
\text { toxin }\end{array}$ \\
\hline 81* & $\begin{array}{l}\text { Venom gland cyclophilin } \\
\text { Glycoprotein IB-binding protein } \alpha\end{array}$ & $\begin{array}{l}38374146 \\
82116886\end{array}$ & $\begin{array}{l}96.96 \\
62.87\end{array}$ & $\begin{array}{l}11 \\
35\end{array}$ & $\begin{array}{l}2 \\
3\end{array}$ & $\begin{array}{c}\text { Bitis gabonica } \\
\text { Bothrops jararaca }\end{array}$ & $\begin{array}{c}\text { Citoplasma } \\
\text { Secretada - CTL }\end{array}$ & $\begin{array}{c}\text { Protein folding } \\
\text { Hemostasis impairing toxin, } \\
\text { Platelet aggregation inhibiting } \\
\text { toxin }\end{array}$ \\
\hline $82 *$ & Glycoprotein IB-binding protein $\alpha$ & 82116886 & 101.75 & 25 & 3 & Bothrops jararaca & Secretada - CTL & $\begin{array}{l}\text { Hemostasis impairing toxin, } \\
\text { Platelet aggregation inhibiting } \\
\text { toxin }\end{array}$ \\
\hline 83* & $\begin{array}{l}\text { Venom gland cyclophilin } \\
\text { Glycoprotein IB-binding protein } \alpha\end{array}$ & $\begin{array}{l}38374146 \\
82116886\end{array}$ & $\begin{array}{l}183.13 \\
118.23\end{array}$ & $\begin{array}{l}59 \\
41\end{array}$ & $\begin{array}{c}20 \\
7\end{array}$ & $\begin{array}{c}\text { Bitis gabonica } \\
\text { Bothrops jararaca }\end{array}$ & $\begin{array}{c}\text { Citoplasma } \\
\text { Secretada - CTL }\end{array}$ & $\begin{array}{c}\text { Protein folding } \\
\text { Hemostasis impairing toxin, } \\
\text { Platelet aggregation inhibiting } \\
\text { toxin }\end{array}$ \\
\hline 84* & $\begin{array}{c}\text { Phospholipase A2 precursor } \\
\text { C-type lectin BiL }\end{array}$ & $\begin{array}{l}86450426 \\
82126834\end{array}$ & $\begin{array}{c}114.11 \\
88.07\end{array}$ & $\begin{array}{l}55 \\
27\end{array}$ & $\begin{array}{l}6 \\
5\end{array}$ & $\begin{array}{l}\text { Bothrops jararaca } \\
\text { Bothrops insularis }\end{array}$ & $\begin{array}{l}\text { Secretada - PLA2 } \\
\text { Secretada - CTL }\end{array}$ & $\begin{array}{c}\text { Inflammatory response } \\
\text { Hemagglutinating activity }\end{array}$ \\
\hline
\end{tabular}


APÊNDICE D - Proteínas identificadas de spots específicos de gel 2-DE das glândulas de veneno da serpente Bothrops jararaca tratadas com reserpina durante 4 dias.

\begin{tabular}{|c|c|c|c|c|c|c|c|c|}
\hline $\begin{array}{l}\mathbf{N}^{0} \text { Spot } \\
\text { Res 4d }\end{array}$ & Proteína & $\begin{array}{l}\text { Número } \\
\text { acesso }\end{array}$ & $\begin{array}{c}\text { Proteína } \\
-10 \lg P\end{array}$ & $\begin{array}{c}\text { Cobertura } \\
\%\end{array}$ & Peptídeo & Organismo & Localização Celular & Processo Biológico \\
\hline \multirow[t]{2}{*}{$85^{*}$} & Phospholipase A2 precursor & 86450426 & 104.06 & 51 & 6 & Bothrops jararaca & Secretada - PLA 2 & Inflammatory response \\
\hline & 40S ribosomal protein S20 & 71725689 & 73.40 & 25 & 3 & Oxyuranus scutellatus & Citoplasma & Translation \\
\hline \multirow[t]{2}{*}{$86^{*}$} & Phospholipase A2 2 & 292630844 & 102.60 & 60 & 4 & Bothrops asper & Secretada - PLA 2 & Inflammatory response \\
\hline & Bothroinsularin subunit alpha & 229621684 & 52.14 & 17 & 2 & Bothrops insularis & Secretada - CTL & $\begin{array}{l}\text { Blood coagulation cascade } \\
\text { inhibiting }\end{array}$ \\
\hline \multirow[t]{2}{*}{ 87\# } & $\begin{array}{l}\text { Coagulation factor IX/factor X-binding } \\
\text { protein subunit A }\end{array}$ & 82116577 & 100.89 & 50 & 5 & Bothrops jararaca & Secretada - CTL & $\begin{array}{l}\text { Blood coagulation cascade } \\
\text { inhibiting toxin }\end{array}$ \\
\hline & Phospholipase A2 2 & 158518414 & 91.13 & 15 & 4 & Bothrops insularis & Secretada - PLA 2 & Inflammatory response \\
\hline \multirow[t]{3}{*}{ 88\# } & Phospholipase A2 2 & 292630844 & 129.56 & 60 & 5 & Bothrops asper & Secretada - PLA 2 & Inflammatory response \\
\hline & C-type lectin isoform 3 & 215275178 & 60.40 & 26 & 3 & Sistrurus c. edwardsi & Secretada - CTL & Hemagglutinating activity \\
\hline & ATP synthase alpha subunit & 118562410 & 78.99 & 18 & 3 & Elaphe quadrivirgata & Mitocôndria & ATP synthesis, Transport \\
\hline \multirow[t]{2}{*}{ 89\# } & Phospholipase A2 2 & 158518414 & 111.50 & 50 & 7 & Bothrops insularis & Secretada - PLA 2 & Inflammatory response \\
\hline & Bothroinsularin subunit beta & 229621684 & 87.15 & 26 & 4 & Bothrops insularis & Secretada - CTL & $\begin{array}{l}\text { Blood coagulation cascade } \\
\text { inhibiting }\end{array}$ \\
\hline 90* & Glycoprotein IB-binding protein $\beta$ & 82116883 & 129.02 & 35 & 3 & Bothrops jararaca & Secretada - CTL & $\begin{array}{l}\text { Hemostasis impairing toxin, } \\
\text { Platelet aggregation inhibiting } \\
\text { toxin }\end{array}$ \\
\hline 91* & Glycoprotein IB-binding protein $\beta$ & 82116883 & 137.74 & 47 & 4 & Bothrops jararaca & Secretada - CTL & $\begin{array}{l}\text { Hemostasis impairing toxin, } \\
\text { Platelet aggregation inhibiting } \\
\text { toxin }\end{array}$ \\
\hline \multirow[t]{3}{*}{ 92\# } & Bothroinsularin subunit alpha & 229621684 & 145.95 & 33 & 8 & Bothrops insularis & Secretada - CTL & Blood coagulation cascade \\
\hline & C-type lectin BiL & 82126834 & 106.55 & 44 & 6 & Bothrops insularis & Secretada - CTL & inhibiting \\
\hline & & & & & & & & Hemagglutinating activity \\
\hline \multirow[t]{3}{*}{ 93\# } & C-type lectin BiL & 82126834 & 167.17 & 77 & 21 & Bothrops insularis & Secretada - CTL & Hemagglutinating activity \\
\hline & Bothroinsularin subunit alpha & 229621684 & 142.39 & 52 & 8 & Bothrops insularis & Secretada - CTL & Blood coagulation cascade \\
\hline & Galactose-specific lectin & 34922459 & 133.92 & 65 & 16 & Bothrops jararacussu & Secretada - CTL & inhibiting \\
\hline
\end{tabular}


APÊNDICE D - Proteínas identificadas de spots específicos de gel 2-DE das glândulas de veneno da serpente Bothrops jararaca tratadas com reserpina durante 4 dias.

\begin{tabular}{|c|c|c|c|c|c|c|c|c|}
\hline $\begin{array}{l}\mathbf{N}^{0} \text { Spot } \\
\text { Res 4d }\end{array}$ & Proteína & $\begin{array}{l}\text { Número } \\
\text { acesso }\end{array}$ & $\begin{array}{c}\text { Proteína } \\
-10 \lg P\end{array}$ & $\begin{array}{c}\text { Cobertura } \\
\%\end{array}$ & Peptídeo & Organismo & Localização Celular & Processo Biológico \\
\hline & & & & & & & & Hemagglutinating activity \\
\hline \multirow[t]{5}{*}{ 94\# } & Glycoprotein IB-binding protein $\beta$ & 82116883 & 198.62 & 74 & 20 & Bothrops jararaca & Secretada - CTL & $\begin{array}{l}\text { Hemostasis impairing toxin, } \\
\text { Platelet aggregation inhibiting }\end{array}$ \\
\hline & Coagulation factor IX/factor X-binding & 32130006 & 103.02 & 30 & 4 & Bothrops jararaca & Secretada - CTL & toxin \\
\hline & protein subunit B1 & & & & & & & Blood coagulation cascade \\
\hline & Thioredoxin & 20140734 & 78.39 & 23 & 2 & Ophiophagus hannah & Citoplasma & inhibiting toxin \\
\hline & & & & & & & & Cell redox homeostasis \\
\hline $95 *$ & Glycoprotein IB-binding protein $\beta$ & 82116883 & 156.11 & 47 & 4 & Bothrops jararaca & Secretada - CTL & $\begin{array}{l}\text { Hemostasis impairing toxin, } \\
\text { Platelet aggregation inhibiting } \\
\text { toxin }\end{array}$ \\
\hline \multirow[t]{3}{*}{ 96* } & Glycoprotein IB-binding protein $\beta$ & 82116883 & 198.62 & 74 & 20 & Bothrops jararaca & Secretada - CTL & $\begin{array}{l}\text { Hemostasis impairing toxin, } \\
\text { Platelet aggregation inhibiting }\end{array}$ \\
\hline & Thioredoxin & 20140734 & 78.39 & 23 & 2 & Ophiophagus hannah & Citoplasma & toxin \\
\hline & & & & & & & & Cell redox homeostasis \\
\hline \multirow[t]{2}{*}{ 97\# } & $\begin{array}{c}\text { Coagulation factor IX/factor X-binding } \\
\text { protein subunit B1 }\end{array}$ & 32130006 & 118.56 & 53 & 6 & Bothrops jararaca & Secretada - CTL & $\begin{array}{c}\text { Blood coagulation cascade } \\
\text { inhibiting toxin }\end{array}$ \\
\hline & Glycoprotein IB-binding protein $\beta$ & 82116883 & 82.95 & 33 & 6 & Bothrops jararaca & Secretada - CTL & $\begin{array}{l}\text { Hemostasis impairing toxin, } \\
\text { Platelet aggregation inhibiting } \\
\text { toxin }\end{array}$ \\
\hline 98\# & Glycoprotein IB-binding protein $\beta$ & 82116883 & 139.28 & 41 & 6 & Bothrops jararaca & Secretada - CTL & $\begin{array}{l}\text { Hemostasis impairing toxin, } \\
\text { Platelet aggregation inhibiting } \\
\text { toxin }\end{array}$ \\
\hline 99\# & $\begin{array}{c}14 \text { kDa phosphohistidine phosphatase- } \\
\text { like }\end{array}$ & 327281524 & 60.70 & 23 & 3 & Anolis carolinesnis & Citoplasma & $\begin{array}{c}\text { Regulation of actin cytoskeleton } \\
\text { reorganization }\end{array}$ \\
\hline 100\# & $\begin{array}{c}14 \text { kDa phosphohistidine phosphatase- } \\
\text { like }\end{array}$ & 327281524 & 70.11 & 18 & 2 & Anolis carolinensis & Citoplasma & $\begin{array}{c}\text { Regulation of actin cytoskeleton } \\
\text { reorganization }\end{array}$ \\
\hline
\end{tabular}


APÊNDICE D - Proteínas identificadas de spots específicos de gel 2-DE das glândulas de veneno da serpente Bothrops jararaca tratadas com reserpina durante 4 dias.

\begin{tabular}{|c|c|c|c|c|c|c|c|c|}
\hline $\begin{array}{l}\mathbf{N}^{0} \text { Spot } \\
\text { Res 4d }\end{array}$ & Proteína & $\begin{array}{c}\text { Número } \\
\text { acesso }\end{array}$ & $\begin{array}{c}\text { Proteína } \\
-10 \lg P\end{array}$ & $\begin{array}{c}\text { Cobertura } \\
\%\end{array}$ & Peptídeo & Organismo & Localização Celular & Processo Biológico \\
\hline $101 *$ & Thioredoxin & 20140734 & 126.60 & 46 & 9 & Ophiophagus hannah & Citoplasma & Cell redox homeostasis \\
\hline
\end{tabular}

Nota: (*) Dados obtidos no banco de dados Metazoa nr 19082011 e Proteopeptidome_NCBInr_29042012 do MALDI-TOF/TOF

(\#) Dados obtidos no banco de dados Metazoa nr 19082011 e Proteopeptidome_NCBInr_29042012 do Orbitrap

Retículo endoplasmático (ER), Lectinas tipo C (CTL), Serinoproteinases (SVSP), Proteínas secretadas ricas em cisteína (CRISP), Classes de Metaloproteinases (PI, PII, PIII), Fosfolipases A2 (PLA $)$, L-aminoácido oxidase (LAAO), Inibidores de Fosfolipases A2 (PLI). 
APÊNDICEE 
APÊNDICE E - Proteínas identificadas de spots específicos de gel 2-DE das glândulas de veneno da serpente Bothrops jararaca tratadas com reserpina, fenilefrina e isoprenalina durante 4 dias.

\begin{tabular}{|c|c|c|c|c|c|c|c|c|}
\hline $\begin{array}{l}\mathrm{N}^{0} \text { Spot } \\
\text { RFI 4d }\end{array}$ & Proteína & $\begin{array}{l}\text { Número } \\
\text { acesso }\end{array}$ & $\begin{array}{l}\text { Proteína } \\
-10 \lg P\end{array}$ & $\begin{array}{c}\text { Cobertura } \\
\%\end{array}$ & Peptídeo & Organismo & Localização Celular & Processo Biológico \\
\hline $1 *$ & $\begin{array}{l}\text { Zinc metalloproteinase-disintegrin } \\
\text { BITM06A }\end{array}$ & 82214993 & 138.37 & 44 & 28 & Bothrops insularis & Secretada - PIII & Proteolysis \\
\hline $2 *$ & $\begin{array}{l}\text { Zinc metalloproteinase-disintegrin } \\
\text { BITM06A }\end{array}$ & 82214993 & 94.13 & 12 & 2 & Bothrops insularis & Secretada - PIII & Proteolysis \\
\hline $3 *$ & Heat shock $70 \mathrm{kDa}$ protein & 242003741 & 412.52 & 7 & 4 & Pediculus humanus corporis & Citoplasma & Stress response \\
\hline 4\# & $\begin{array}{l}\text { Anti-hemorragic factor } \mathrm{Bj} 46 \mathrm{a} \\
\text { L-amino acid oxidade } \\
\text { PDI }\end{array}$ & $\begin{array}{c}48428681 \\
195927838 \\
63146076\end{array}$ & $\begin{array}{l}153.43 \\
132.89 \\
106.65\end{array}$ & $\begin{array}{l}48 \\
26 \\
18\end{array}$ & $\begin{array}{l}20 \\
11 \\
9\end{array}$ & $\begin{array}{c}\text { Bothrops jararaca } \\
\text { Bothropoides pauloensis } \\
\text { Oxyuranus scutellatus }\end{array}$ & $\begin{array}{c}\text { Secretada } \\
\text { Secretada - LAAO } \\
\text { Retículo endoplasmático }\end{array}$ & $\begin{array}{c}\text { Negative regulation of proteolysis } \\
\text { Apoptosis, Cytolysis, Hemolysis } \\
\text { Homeostasis, Metabolic and } \\
\text { apoptotic process }\end{array}$ \\
\hline $5^{*}$ & Anti-hemorragic factor $\mathrm{Bj} 46 \mathrm{a}$ & 48428681 & 94.16 & 11 & 2 & Bothrops jararaca & Secretada & Negative regulation of proteolysis \\
\hline $6^{*}$ & $\begin{array}{l}\text { Chain B, The three dimensional } \\
\text { structure of Bothropasin }\end{array}$ & 209870468 & 151.29 & 9 & 3 & Bothrops jararaca & Secretada - PIII & Cell adhesion \\
\hline \multirow[t]{2}{*}{ 7\# } & $\begin{array}{l}\text { Zinc metalloproteinase-disintegrin } \\
\text { BITM06A }\end{array}$ & 82214993 & 190.19 & 45 & 53 & Bothrops insularis & Secretada - PIII & Proteolysis \\
\hline & Tubulin, alpha 4, isoform CRA_b & 148667971 & 147.25 & 81 & 18 & Mus musculus & Citoplasma & $\begin{array}{l}\text { Microtubule-based movement, } \\
\text { Protein polymerization }\end{array}$ \\
\hline \multirow[t]{3}{*}{$8^{*}$} & $\begin{array}{l}\text { ATP synthase beta subunit } \\
\text { mitochondrial precursor }\end{array}$ & 71897237 & 140.87 & 56 & 27 & Gallus gallus & Mitocôndria & ATP synthesis, Transport \\
\hline & Tubulin beta-4-chain-like & 327263983 & 129.03 & 72 & 27 & Anolis carolinensis & Citoplasma & $\begin{array}{l}\text { Microtubule-based movement, } \\
\text { Protein polymerization }\end{array}$ \\
\hline & $\begin{array}{l}\text { Zinc metalloproteinase-disintegrin } \\
\text { BITM06A }\end{array}$ & 82214993 & 110.93 & 34 & 19 & Bothrops insularis & Secretada - PIII & Proteolysis \\
\hline \multirow[t]{2}{*}{ 9\# } & $\begin{array}{l}\text { ATP synthase subunit beta, } \\
\text { mitochondrial precursor }\end{array}$ & 71897237 & 172.73 & 52 & 16 & Gallus gallus & Mitocôndria & ATP synthesis, Transport \\
\hline & Zinc metalloproteinase-disintegrin & 82214993 & 165.93 & 44 & 35 & Bothrops insularis & Secretada - PIII & Proteolysis \\
\hline
\end{tabular}


APÊNDICE E - Proteínas identificadas de spots específicos de gel 2-DE das glândulas de veneno da serpente Bothrops jararaca tratadas com reserpina, fenilefrina e isoprenalina durante 4 dias. .

\begin{tabular}{|c|c|c|c|c|c|c|c|c|}
\hline $\begin{array}{l}\mathbf{N}^{0} \text { Spot } \\
\text { RFI 4d }\end{array}$ & Proteína & $\begin{array}{l}\text { Número } \\
\text { acesso }\end{array}$ & $\begin{array}{c}\text { Proteína } \\
-10 \lg P\end{array}$ & $\begin{array}{c}\text { Cobertura } \\
\%\end{array}$ & Peptídeo & Organismo & Localização Celular & Processo Biológico \\
\hline & BITM06A & & & & & & & \\
\hline & Vimentin & 17386168 & 139.04 & 24 & 13 & Daboia russellii & Citoplasma & $\begin{array}{l}\text { Intermediate filament } \\
\quad \text { organization }\end{array}$ \\
\hline \multirow[t]{3}{*}{ 10\# } & Zinc metalloproteinase-disintegrin & 82214993 & 178.38 & 47 & 42 & Bothrops insularis & Secretada - PIII & Proteolysis \\
\hline & BITM06A & & & & & & & \\
\hline & Tubulin alpha 4A-chain & 327260422 & 134.85 & 56 & 10 & Anolis carolinensis & Citoplasma & $\begin{array}{l}\text { Microtubule-based movement, } \\
\text { Protein polymerization }\end{array}$ \\
\hline \multirow[t]{2}{*}{ 11\# } & Zinc metalloproteinase-disintegrin & 82214993 & 149.43 & 32 & 28 & Bothrops insularis & Secretada - PIII & Proteolysis \\
\hline & $\begin{array}{c}\text { BITM06A } \\
\text { Protein disulfide isomerase A3- } \\
\text { precursor }\end{array}$ & 387017522 & 116.06 & 36 & 10 & Crotalus adamanteus & Retículo endoplasmático & $\begin{array}{c}\text { Homeostasis, Metabolic and } \\
\text { apoptotic process }\end{array}$ \\
\hline $12 *$ & $\begin{array}{l}\text { Protein disulfide isomerase family } \\
\qquad \text { A, member } 3\end{array}$ & 45361505 & 83.00 & 23 & 4 & Xenopus tropicalis & Retículo endoplasmático & $\begin{array}{c}\text { Homeostasis, Metabolic and } \\
\text { apoptotic process }\end{array}$ \\
\hline \multirow[t]{3}{*}{$13 *$} & $\begin{array}{l}\text { Aldehyde dehydrogenase } 9 \\
\text { family, member A1 }\end{array}$ & 224058898 & 74.75 & 11 & 3 & Taeniopygia guttata & Citoplasma & Metabolic process \\
\hline & L-amino acid oxidase precursor & 195927838 & 107.41 & 11 & 5 & Bothropoides pauloensis & Secretada - LAAO & Apoptosis, Cytolysis, Hemolysis \\
\hline & $\begin{array}{l}\text { Protein disulfide isomerase A3- } \\
\text { precursor }\end{array}$ & 387017522 & 102.89 & 26 & 6 & Crotalus adamanteus & Retículo endoplasmático & $\begin{array}{c}\text { Cell redox homeostasis, } \\
\text { Metabolic process }\end{array}$ \\
\hline \multirow[t]{3}{*}{$14 *$} & Actin, alpha skeletal muscle & 67462115 & 200.28 & 13 & 4 & Atractaspis microlepidota & Citoplasma & Skeletal muscle fiber \\
\hline & Beta actin & 58198383 & 155.33 & 20 & 3 & Pseudonaja textilis & Citoplasma & development \\
\hline & & & & & & & & Structural element organization \\
\hline $15^{*}$ & Beta actin & 52078486 & 117.46 & 25 & 4 & Oxyuranus scutellatus & Citoplasma & Structural element organization \\
\hline $16^{*}$ & Actin, alpha skeletal muscle & 67462115 & 170.08 & 16 & 5 & Atractaspis microlepidota & Citoplasma & $\begin{array}{l}\text { Skeletal muscle fiber } \\
\text { development }\end{array}$ \\
\hline $17 *$ & Actin, alpha skeletal muscle & 67462115 & 119.46 & 13 & 3 & Atractaspis microlepidota & Citoplasma & Skeletal muscle fiber \\
\hline
\end{tabular}


APÊNDICE E - Proteínas identificadas de spots específicos de gel 2-DE das glândulas de veneno da serpente Bothrops jararaca tratadas com reserpina, fenilefrina e isoprenalina durante 4 dias. .

\begin{tabular}{|c|c|c|c|c|c|c|c|c|}
\hline $\begin{array}{l}\mathbf{N}^{0} \text { Spot } \\
\text { RFI 4d }\end{array}$ & Proteína & $\begin{array}{l}\text { Número } \\
\text { acesso }\end{array}$ & $\begin{array}{c}\text { Proteína } \\
-10 \lg P\end{array}$ & $\begin{array}{c}\text { Cobertura } \\
\%\end{array}$ & Peptídeo & Organismo & Localização Celular & Processo Biológico \\
\hline & Beta actin & 58198383 & 132.70 & 20 & 3 & Pseudonaja textilis & Citoplasma & development \\
\hline & & & & & & & & Structural element organization \\
\hline 18\# & Alpha enolase & 17367183 & 46.22 & 14 & 3 & Phyton regius & Citoplasma & Glycolysis \\
\hline \multirow[t]{3}{*}{$19 *$} & Actin, alpha skeletal muscle & 67462115 & 140.11 & 16 & 4 & Atractaspis microlepidota & Citoplasma & Skeletal muscle fiber \\
\hline & Beta actin & 58198383 & 136.84 & 25 & 4 & Pseudonaja textilis & Citoplasma & development \\
\hline & & & & & & & & Structural element organization \\
\hline \multirow[t]{4}{*}{ 20\# } & Tyrosine 3- & 224076320 & 76.33 & 29 & 4 & Taeniopygia guttata & Mitocôndria & Protein targeting to mitochondria \\
\hline & $\begin{array}{c}\text { monooxygenase/tryptophan 5- } \\
\text { monooxygenase activation } \\
\text { protein, epsilon polypeptide }\end{array}$ & & & & & & & \\
\hline & Nucleophosmin-like & 387017382 & 142.94 & 61 & 11 & Crotalus adamanteus & Núcleo & DNA repair, protein oligomerization \\
\hline & Beta actin & 52078486 & 129.82 & 36 & 7 & Oxyuranus scutellatus & Citoplasma & Structural element organization \\
\hline \multirow[t]{2}{*}{ 21\# } & $\begin{array}{l}\text { Platelet aggregating serine } \\
\text { peptidase }\end{array}$ & 34148047 & 94.67 & 354 & 6 & Bothrops jararaca & Secretada - SVSP neutro & Proteolysis \\
\hline & Venom metalloproteinase jararin & 87245249 & 88.27 & 36 & 5 & Bothrops jararaca & Secretada - PII & Cell Adhesion, Proteolysis \\
\hline \multirow[t]{2}{*}{$22 *$} & Venom serine proteinase HS114 & 82233395 & 126.12 & 44 & 16 & Bothrops jararaca & Secretada - SVSP ácido & Proteolysis \\
\hline & Beta tropomyosin & 6573280 & 118.67 & 33 & 8 & Homo sapiens & Citoplasma & $\begin{array}{c}\text { Muscle contraction, Regulation of } \\
\text { ATPase activity }\end{array}$ \\
\hline \multirow[t]{2}{*}{$23^{*}$} & Venom serine proteinase HS114 & 82233395 & 174.68 & 63 & 25 & Bothrops jararaca & Secretada - SVSP ácido & Proteolysis \\
\hline & Beta tropomyosin & 6573280 & 133.50 & 33 & 11 & Homo sapiens & Citoplasma & $\begin{array}{c}\text { Muscle contraction, Regulation of } \\
\text { ATPase activity }\end{array}$ \\
\hline 24\# & Venom serine proteinase HS114 & 82233395 & 155.78 & 51 & 18 & Bothrops jararaca & Secretada - SVSP ácido & Proteolysis \\
\hline \multirow[t]{3}{*}{ 25\# } & $\begin{array}{l}\text { Proteasome subunit alpha type } 3 \text { - } \\
\text { like }\end{array}$ & 126282483 & 88.84 & 42 & 7 & Monodelphis domestica & Citoplasma & $\begin{array}{l}\text { Ubiquitin-dependent protein } \\
\text { catabolic process }\end{array}$ \\
\hline & & 52078486 & 138.69 & 50 & 10 & Oxyuranus scutellatus & Citoplasma & Structural element organization \\
\hline & Beta actin & 123883733 & 107.51 & 23 & 7 & Bothrops asper & Secretada - SVSP ácido & Metabolic process \\
\hline
\end{tabular}


APÊNDICE E - Proteínas identificadas de spots específicos de gel 2-DE das glândulas de veneno da serpente Bothrops jararaca tratadas com reserpina, fenilefrina e isoprenalina durante 4 dias. .

\begin{tabular}{|c|c|c|c|c|c|c|c|c|}
\hline $\begin{array}{l}\mathbf{N}^{0} \text { Spot } \\
\text { RFI 4d }\end{array}$ & Proteína & $\begin{array}{l}\text { Número } \\
\text { acesso }\end{array}$ & $\begin{array}{c}\text { Proteína } \\
-10 \lg P\end{array}$ & $\begin{array}{c}\text { Cobertura } \\
\%\end{array}$ & Peptídeo & Organismo & Localização Celular & Processo Biológico \\
\hline & Venom serine proteinase-like & & & & & & & \\
\hline \multirow[t]{2}{*}{ 26\# } & Venom serine proteinase HS114 & 82233395 & 164.30 & 59 & 22 & Bothrops jararaca & Secretada - SVSP ácido & Proteolysis \\
\hline & Actin, alpha skeletal muscle & 67462115 & 122.25 & 24 & 7 & Atractaspis microlepidota & Citoplasma & $\begin{array}{l}\text { Skeletal muscle fiber } \\
\text { development }\end{array}$ \\
\hline \multirow[t]{3}{*}{ 27\# } & *Venom serine proteinase-like & 123883733 & 111.33 & 32 & 9 & Bothrops asper & Secretada - SVSP ácido & Metabolic process \\
\hline & *Actin, alpha skeletal muscle & 67462115 & 118.04 & 19 & 9 & Atractaspis microlepidota & Citoplasma & Skeletal muscle fiber development \\
\hline & $\begin{array}{l}\text { Eukaryotic translation initiation } \\
\text { factor } 3 \text { subunit 3-like }\end{array}$ & 327288084 & 86.57 & 25 & 4 & Anolis carolinensis & Citoplasma & Translational initiation \\
\hline \multirow[t]{2}{*}{ 28\# } & 14-3-3 protein & 530049 & 79.02 & 45 & 5 & Ovis aires & Citoplasma & $\begin{array}{l}\text { Negative regulation of } \\
\text { transcription }\end{array}$ \\
\hline & Cytoskeletal tropomyosin & 833603 & 78.93 & 40 & 7 & Coturnix coturnix & Citoplasma & Muscle contraction \\
\hline \multirow[t]{3}{*}{ 33* } & $\begin{array}{c}\text { *Jararhagin } \mathrm{C}=28 \mathrm{kda} \text { disintegrin } \\
\text { homolog }\end{array}$ & 546898 & 110.20 & 39 & 7 & Bothrops jararaca & Secretada & $\begin{array}{l}\text { Cell adhesion, Apoptosis, } \\
\text { Inflamatory response }\end{array}$ \\
\hline & $\begin{array}{c}* \text { Chain A, The three-dimensional } \\
\text { structure of bothropasin }\end{array}$ & 253722676 & 143.07 & 37 & 19 & Bothrops jararaca & Secretada - PIII & Cell adhesion \\
\hline & $\begin{array}{c}\text { Tyrosine 3- } \\
\text { monooxygenase/tryptophan 5- } \\
\text { monooxygenase activation } \\
\text { protein, beta polypeptide }\end{array}$ & 66347207 & 65.76 & 28 & 4 & Homo sapiens & Mitocôndria & Protein targeting to mitochondria \\
\hline \multirow[t]{2}{*}{$34 *$} & $\begin{array}{l}\text { Voltage-dependent anion selective } \\
\text { channel protein 1-like }\end{array}$ & 327265290 & 76.83 & 31 & 3 & Anolis carolinensis & Mitocôndria & Ion transport \\
\hline & ${ }^{*}$ Cysteine-rich secretory protein 1 & 358801543 & 132.54 & 41 & 7 & Crotalus oreganus helleri & Secretada - CRISP & - \\
\hline $35^{*}$ & $\begin{array}{c}\text { Gamma phospholipase } \mathrm{A} 2 \\
\text { inhibitor }\end{array}$ & 157885066 & 132.19 & 32 & 7 & Bothrops jararaca & Secretada - PLI & $\begin{array}{c}\text { Regulation of phospholipase A2 } \\
\text { activity }\end{array}$ \\
\hline $36^{*}$ & $\begin{array}{c}\text { Gamma phospholipase A2 } \\
\text { inhibitor }\end{array}$ & 157885066 & 96.28 & 32 & 5 & Bothrops jararaca & Secretada - PLI & $\begin{array}{c}\text { Regulation of phospholipase A2 } \\
\text { activity }\end{array}$ \\
\hline
\end{tabular}


APÊNDICE E - Proteínas identificadas de spots específicos de gel 2-DE das glândulas de veneno da serpente Bothrops jararaca tratadas com reserpina, fenilefrina e isoprenalina durante 4 dias. .

\begin{tabular}{|c|c|c|c|c|c|c|c|c|}
\hline $\begin{array}{l}\mathbf{N}^{0} \text { Spot } \\
\text { RFI 4d }\end{array}$ & Proteína & $\begin{array}{l}\text { Número } \\
\text { acesso }\end{array}$ & $\begin{array}{c}\text { Proteína } \\
\text {-10lgP }\end{array}$ & $\begin{array}{c}\text { Cobertura } \\
\%\end{array}$ & Peptídeo & Organismo & Localização Celular & Processo Biológico \\
\hline $37 *$ & $\begin{array}{c}\text { Gamma phospholipase } \mathrm{A} 2 \\
\text { inhibitor }\end{array}$ & 157885066 & 100.22 & 32 & 5 & Bothrops jararaca & Secretada - PLI & $\begin{array}{c}\text { Regulation of phospholipase A2 } \\
\text { activity }\end{array}$ \\
\hline \multirow[t]{2}{*}{ 38\# } & $\begin{array}{l}\text { Zinc metalloproteinase-disntegrin } \\
\text { BITM02A }\end{array}$ & 82214994 & 107.27 & 24 & 9 & Bothrops insularis & Secretada - PI & Proteolysis \\
\hline & Actin, alpha skeletal muscle & 67462115 & 103.92 & 16 & 6 & Atractaspis microlepidota & Citoplasma & $\begin{array}{c}\text { Skeletal muscle fiber } \\
\text { development }\end{array}$ \\
\hline \multirow[t]{3}{*}{ 39\# } & $\begin{array}{l}\text { 26S proteasome non-ATPase } \\
\text { regulatory subunit } 8 \text {-like }\end{array}$ & 327284479 & 45.61 & 11 & 2 & Anolis carolinensis & Citoplasma & $\begin{array}{l}\text { Ubiquitin-dependent protein } \\
\text { catabolic process }\end{array}$ \\
\hline & Cysteine-rich secretory protein 2 & 358801574 & 78.37 & 23 & 4 & Crotalus oreganus helleri & Secretada - CRISP & - \\
\hline & $\begin{array}{l}\text { Zinc metalloproteinase } \\
\text { BmooMPalfa-I }\end{array}$ & 259090190 & 82.38 & 12 & 3 & Bothrops moojeni & Secretada - PI & Proteolysis \\
\hline $40 *$ & Proteasome subunit alpha type 6 & 225705796 & 720.69 & 17 & 3 & Oncorhynchus mykiss & Citoplasma & $\begin{array}{l}\text { Ubiquitin-dependent protein } \\
\text { catabolic process }\end{array}$ \\
\hline $41^{*}$ & Calbidin D28k & 55003506 & 1176.80 & 12 & 4 & Sorghum bicolor & Citoplasma & Calcium ion transport \\
\hline $42 *$ & Myosin light chain 4 & 115496173 & 86.33 & 30 & 3 & Bos taurus & Citoplasma & Muscle contraction \\
\hline \multirow[t]{2}{*}{$43^{*}$} & Rho GDP-dissociation inhibitor 1 & 124249432 & 63.82 & 30 & 3 & Gallus gallus & Citoplasma & Regulation GTPase activity \\
\hline & Zinc metalloproteinase $\mathrm{BnP1}$ & 172044591 & 94.70 & 37 & 4 & Bothropoides pauloensis & Secretada - PI & Apoptosis \\
\hline 44\# & $\begin{array}{c}\text { Beta actin } \\
\text { Zinc metalloproteinase } \\
\text { BmooMPalpha-I }\end{array}$ & $\begin{array}{c}52078486 \\
259090190\end{array}$ & $\begin{array}{l}97.49 \\
79.84\end{array}$ & $\begin{array}{l}35 \\
12\end{array}$ & $\begin{array}{l}5 \\
3\end{array}$ & $\begin{array}{l}\text { Oxyuranus scutellatus } \\
\text { Crotalus oreganus helleri }\end{array}$ & $\begin{array}{c}\text { Citoplasma } \\
\text { Secretada - PI }\end{array}$ & $\begin{array}{c}\text { Structural element organization } \\
\text { Proteolysis }\end{array}$ \\
\hline $45^{*}$ & Zinc metalloproteinase $\mathrm{BnP} 2$ & 172044592 & 96.28 & 32 & 3 & Bothropoides pauloensis & Secretada - PI & Apoptosis \\
\hline $46^{*}$ & $\begin{array}{c}\text { Beta actin } \\
\text { Zinc metalloproteinase BnP1 }\end{array}$ & $\begin{array}{c}52078486 \\
172044591\end{array}$ & $\begin{array}{l}137.24 \\
92.91\end{array}$ & $\begin{array}{l}45 \\
37\end{array}$ & $\begin{array}{l}7 \\
4\end{array}$ & $\begin{array}{c}\text { Oxyuranus scutellatus } \\
\text { Bothropoides pauloensis }\end{array}$ & $\begin{array}{c}\text { Citoplasma } \\
\text { Secretada - PI }\end{array}$ & $\begin{array}{c}\text { Structural element organization } \\
\text { Apoptosis }\end{array}$ \\
\hline $47 *$ & $\begin{array}{c}\text { Zinc metalloproteinase } \mathrm{BnP} 2 \\
\text { Gluthatione S-transferase P-like }\end{array}$ & $\begin{array}{l}172044592 \\
387016254\end{array}$ & $\begin{array}{l}139.59 \\
130.32\end{array}$ & $\begin{array}{l}96 \\
56\end{array}$ & $\begin{array}{l}11 \\
10\end{array}$ & $\begin{array}{l}\text { Bothropoides pauloensis } \\
\text { Crotalus adamanteus }\end{array}$ & $\begin{array}{c}\text { Secretada - PI } \\
\text { Citoplasma }\end{array}$ & $\begin{array}{l}\text { Apoptosis } \\
\text { Gluthatione metabolic process }\end{array}$ \\
\hline 48\# & Zinc metalloproteinase BnP1 & 172044591 & 99.38 & 46 & 5 & Bothropoides pauloensis & Secretada - PI & Apoptosis \\
\hline
\end{tabular}


APÊNDICE E - Proteínas identificadas de spots específicos de gel 2-DE das glândulas de veneno da serpente Bothrops jararaca tratadas com reserpina, fenilefrina e isoprenalina durante 4 dias. .

\begin{tabular}{|c|c|c|c|c|c|c|c|c|}
\hline $\begin{array}{l}\mathrm{N}^{0} \text { Spot } \\
\text { RFI 4d }\end{array}$ & Proteína & $\begin{array}{l}\text { Número } \\
\text { acesso }\end{array}$ & $\begin{array}{c}\text { Proteína } \\
-10 \operatorname{lgP}\end{array}$ & $\begin{array}{c}\text { Cobertura } \\
\%\end{array}$ & Peptídeo & Organismo & Localização Celular & Processo Biológico \\
\hline \multirow[t]{2}{*}{ 49\# } & Gluthatione S-transferase P-like & 387016254 & 135.22 & 33 & 12 & Crotalus adamanteus & Citoplasma & Gluthatione metabolic process \\
\hline & Proteasome-like protein & 71725697 & 69.57 & 19 & 2 & Oxyuranus scutellatus & Citoplasma & $\begin{array}{l}\text { Ubiquitin-dependent protein } \\
\text { catabolic process }\end{array}$ \\
\hline \multirow[t]{2}{*}{$50 *$} & Proteasome-like protein & 71725697 & 63.46 & 37 & 3 & Oxyuranus scutellatus & Citoplasma & $\begin{array}{l}\text { Ubiquitin-dependent protein } \\
\text { catabolic process }\end{array}$ \\
\hline & Zinc metalloproteinase $\mathrm{BnP} 2$ & 172044592 & 55.99 & 26 & 2 & Bothropoides pauloensis & Secretada - PI & Apoptosis \\
\hline 51\# & Zinc metalloproteinase $\mathrm{BnP} 2$ & 172044592 & 133.24 & 93 & 20 & Bothropoides pauloensis & Secretada - PI & Apoptosis \\
\hline 52\# & $\begin{array}{c}\text { Chain A, The three dimensional } \\
\text { struture of Bothropasin }\end{array}$ & 253722676 & 105.23 & 13 & 6 & Bothrops jararaca & Secretada - PIII & Cell adhesion \\
\hline \multirow[t]{2}{*}{$\mathbf{5 3}^{*}$} & $\begin{array}{c}\text { Alpha-type phospholipase A2 } \\
\text { inhibitor }\end{array}$ & 215275475 & 126.53 & 57 & 12 & Bothrops jararaca & Secretada - PLI & $\begin{array}{c}\text { Regulation of phospholipase A2 } \\
\text { activity }\end{array}$ \\
\hline & Beta actin & 52078486 & 112.24 & 35 & 5 & Oxyuranus scutellatus & Citoplasma & Structural element organization \\
\hline 54\# & $\begin{array}{c}\text { Adenine } \\
\text { phosphoribosyltransferase-like }\end{array}$ & 387014644 & 92.89 & 80 & 5 & Crotalus adamanteus & Citoplasma & AMP salvage, Purine salvage \\
\hline \multirow[t]{2}{*}{$55 \#$} & $\begin{array}{l}\text { ATP synthase subunit H+ } \\
\text { transporting mitochondrial }\end{array}$ & BINS0740S & 182.47 & 67 & 21 & - & Mitocôndria & ATP synthesis, Transport \\
\hline & $\begin{array}{c}\text { Alpha-type phospholipase A2 } \\
\text { inhibitor }\end{array}$ & 215275475 & 104.96 & 44 & 9 & Bothrops jararaca & Secretada - PLI & $\begin{array}{c}\text { Regulation of phospholipase A2 } \\
\text { activity }\end{array}$ \\
\hline $56^{*}$ & Ferritin havy chain-like & 301781722 & 570.89 & 12 & 2 & Ailuropoda melanoleuca & Mitocôndria & Iron ion transport \\
\hline $57 *$ & $\begin{array}{l}\text { Myosin light polypeptide 6-like } \\
\text { isoform } 1 \\
\text { Bothroinsularin subunit beta }\end{array}$ & $\begin{array}{l}327264385 \\
229621685\end{array}$ & $\begin{array}{l}125.89 \\
156.83\end{array}$ & $\begin{array}{l}69 \\
51\end{array}$ & $\begin{array}{c}9 \\
14\end{array}$ & $\begin{array}{l}\text { Anolis carolinensis } \\
\text { Bothrops insularis }\end{array}$ & $\begin{array}{c}\text { Citoplasma } \\
\text { Secretada - CTL }\end{array}$ & $\begin{array}{c}\text { Muscle contraction } \\
\text { Blood coagulation cascade } \\
\text { inhibiting }\end{array}$ \\
\hline \multirow[t]{2}{*}{ 58* } & Botrocetin subunit alpha & 264834 & 115.09 & 50 & 9 & Bothrops jararaca & Secretada - CTL & $\begin{array}{c}\text { Blood coagulation cascade } \\
\text { inhibiting }\end{array}$ \\
\hline & Bothroinsularin subunit beta alpha & 229621685 & 93.03 & 36 & 7 & Bothrops insularis & Secretada - CTL & $\begin{array}{l}\text { Blood coagulation cascade } \\
\text { inhibiting }\end{array}$ \\
\hline
\end{tabular}


APÊNDICE E - Proteínas identificadas de spots específicos de gel 2-DE das glândulas de veneno da serpente Bothrops jararaca tratadas com reserpina, fenilefrina e isoprenalina durante 4 dias. .

\begin{tabular}{|c|c|c|c|c|c|c|c|c|}
\hline $\begin{array}{l}\mathbf{N}^{0} \text { Spot } \\
\text { RFI 4d }\end{array}$ & Proteína & $\begin{array}{l}\text { Número } \\
\text { acesso }\end{array}$ & $\begin{array}{c}\text { Proteína } \\
-10 \lg P\end{array}$ & $\begin{array}{c}\text { Cobertura } \\
\%\end{array}$ & Peptídeo & Organismo & Localização Celular & Processo Biológico \\
\hline $59 *$ & Calmodulin & 12862373 & 500.29 & 14 & 2 & Clemmys japonica & Citoplasma & Metabolic process \\
\hline $60 *$ & Bothroinsularin subunit beta & 229621685 & 116.62 & 35 & 6 & Bothrops insularis & Secretada - CTL & $\begin{array}{l}\text { Blood coagulation cascade } \\
\text { inhibiting }\end{array}$ \\
\hline \multirow[t]{2}{*}{$61^{*}$} & Bothrojaracin subunit beta & 82124360 & 56.72 & 20 & 2 & Bothrops jararaca & Secretada - CTL & $\begin{array}{l}\text { Blood coagulation cascade } \\
\text { inhibiting }\end{array}$ \\
\hline & Alpha actin & 52078484 & 83.76 & 24 & 4 & Oxyuranus scutellatus & Citoplasma & Structural element organization \\
\hline \multirow[t]{2}{*}{$62 \#$} & Alpha actin & 52078484 & 102.16 & 24 & 4 & Oxyuranus scutellatus & Citoplasma & $\begin{array}{c}\text { Structural element organization } \\
\text { Hemostasis impairing toxin, }\end{array}$ \\
\hline & $\begin{array}{c}\text { Glycoprotein IB-binding protein } \\
\text { subunit } \beta\end{array}$ & 82116883 & 72.03 & 26 & 4 & Bothrops jararaca & Secretada - CTL & $\begin{array}{c}\text { Platelet aggregation inhibiting } \\
\text { toxin }\end{array}$ \\
\hline
\end{tabular}

Nota: (*) Dados obtidos no banco de dados Metazoa nr 19082011 e Proteopeptidome_NCBInr_29042012 do MALDI-TOF/TOF

(\#) Dados obtidos no banco de dados Metazoa nr 19082011 e Proteopeptidome_NCBInr_29042012 do Orbitrap

Retículo endoplasmático (ER), Lectinas tipo C (CTL), Serinoproteinases (SVSP), Proteínas secretadas ricas em cisteína (CRISP), Classes de Metaloproteinases (PI, PII, PIII), L-aminoácido oxidase (LAAO), Inibidores de Fosfolipases A2 (PLI). 
APÊNDICE F 
APÊNDICE F - Proteínas da glândula acessória da serpente Bothrops jararaca que não sofreu extração de veneno identificadas através do nanoESI-LTQ/Orbitrap XL.

\begin{tabular}{|c|c|c|c|c|c|c|c|c|}
\hline $\begin{array}{c}N^{\circ} . \text { Banda } \\
\text { 0 d }\end{array}$ & Nome da Proteína & $\begin{array}{c}\text { Número } \\
\text { Acesso }\end{array}$ & $\begin{array}{c}\text { Proteína } \\
\text {-10lgP } \\
\end{array}$ & Cobertura \% & Peptídeos & Únicos & $\begin{array}{c}\text { Localização } \\
\text { Celular }\end{array}$ & Organismo \\
\hline \multirow[t]{4}{*}{1} & $\mathrm{Na} / \mathrm{K}-\mathrm{ATPase}$ & 336043940 & 226.20 & 25 & 9 & 9 & Membrana & L. semifasciata \\
\hline & Putative ADP/ATP translocase & 324497718 & 99.75 & 25 & 8 & 8 & Membrana & H. judaicus \\
\hline & Ribosomal protein L8 & 336042958 & 75.24 & 32 & 3 & 3 & Citoplasma & L. semifasciata \\
\hline & Snake venom metalloprotease inhibitor precursor & 159232573 & 46.57 & 18 & 4 & 3 & Secretada - pEKW & Echis ocellatus \\
\hline \multirow[t]{5}{*}{2} & $\mathrm{Na} / \mathrm{K}$-ATPase & 336043940 & 226.20 & 25 & 9 & 9 & Membrana & L. semifasciata \\
\hline & HSP70 & 63146078 & 305.30 & 43 & 30 & 23 & Citoplasma & O. scutellatus \\
\hline & Myosin-9 & 161669238 & 107.10 & 21 & 7 & 6 & Citoplasma & L. singoriensis \\
\hline & Thrombin-like enzyme & 82466483 & 162.71 & 37 & 11 & 3 & Secretada - SVSP & Bothrops asper \\
\hline & Disintegrin jararin & 123911605 & 142.93 & 31 & 6 & 2 & Secretada & Bothrops jararaca \\
\hline \multirow[t]{8}{*}{3} & $\mathrm{Na} / \mathrm{K}$-ATPase & 336043940 & 226.20 & 25 & 9 & 9 & Membrana & L. semifasciata \\
\hline & Phosphodiesterase 1 & 338855302 & 169.09 & 10 & 8 & 8 & Citoplasma & C. adamanteus \\
\hline & 40 S ribosomal protein $S 2$, partial & 71725683 & 129.14 & 35 & 9 & 5 & Citoplasma & O. scutellatus \\
\hline & 60s ribosomal protein L10 & 260207865 & 88.68 & 18 & 6 & 5 & Citoplasma & Tityus discrepans \\
\hline & Transport protein Sec61 beta subunit & 387018500 & 95.00 & 29 & 4 & 4 & RE & C. adamanteus \\
\hline & C-type natriuretic peptide & 123884707 & 41.00 & 29 & 4 & 4 & Secretada & Philodryas olfersii \\
\hline & Dipeptidylpeptidase $4 \mathrm{~b}$ & 40363636 & 112.90 & 11 & 9 & 3 & Membrana & G. brevicaudus \\
\hline & MP_III2 SVMP precursor, partial & 308212498 & 138.46 & 30 & 16 & 2 & Secretada-PIII & Bothrops neuwiedi \\
\hline \multirow[t]{6}{*}{4} & Actinin alpha 4 & 269994460 & 241.32 & 41 & 17 & 17 & Citoplasma & L. r. rubritaeniata \\
\hline & Phosphodiesterase 1 & 338855302 & 169.09 & 10 & 8 & 8 & Citoplasma & C. adamanteus \\
\hline & Bothrocetin & 13399950 & 198.67 & 73 & 20 & 8 & Secretada - CTL & Bothrops jararaca \\
\hline & Dipeptidylpeptidase $4 \mathrm{~b}$ & 40363636 & 112.90 & 11 & 9 & 3 & Membrana & G. brevicaudus \\
\hline & Elongation factor 2 & 63146080 & 76.45 & 15 & 6 & 3 & Citoplasma & O. s. scutellatus \\
\hline & Heat shock protein 90 & 89515102 & 141.81 & 12 & 12 & 2 & RE & Bufo gargarizans \\
\hline \multirow[t]{10}{*}{5} & HSP70 & 63146078 & 305.30 & 43 & 30 & 23 & Citoplasma & O. scutellatus \\
\hline & Actinin alpha 4 & 269994460 & 241.31 & 41 & 17 & 17 & Citoplasma & L. $r$ rubritaeniata \\
\hline & Serum albumin & 56790036 & 185.24 & 18 & 13 & 13 & Secretada & T. flavoviridis \\
\hline & Heat shock protein 8 -like & 269994458 & 250.91 & 52 & 17 & 11 & Citoplasma & L. $r$ rubritaeniata \\
\hline & Transferrin precursor & 108792443 & 134.24 & 13 & 11 & 5 & Membrana & Python bivittatus \\
\hline & MP_III3 SVMP precursor, partial & 308212500 & 175.09 & 22 & 13 & 4 & Secretada - PIII & Bothrops neuwiedi \\
\hline & Dipeptidylpeptidase $4 \mathrm{~b}$ & 40363636 & 112.90 & 11 & 9 & 3 & Membrana & G. brevicaudus \\
\hline & Golgi-associated protein & 67480125 & 103.92 & 23 & 3 & 3 & Golgi & O. s. scutellatus \\
\hline & Elongation factor 2 & 63146080 & 76.45 & 15 & 6 & 3 & Citoplasma & O. s. scutellatus \\
\hline & Heat shock protein 90 & 89515102 & 141.81 & 12 & 12 & 2 & RE & Bufo gargarizans \\
\hline \multirow[t]{5}{*}{6} & HSP70 & 63146078 & 305.30 & 43 & 30 & 23 & Citoplasma & O. scutellatus \\
\hline & Vimentin & 17386168 & 165.19 & 28 & 19 & 14 & Citoplasma & Daboia russellii \\
\hline & Serum albumin & 56790036 & 185.24 & 18 & 13 & 13 & Secretada & T. flavoviridis \\
\hline & ATP synthase beta chain & 372479772 & 165.68 & 22 & 9 & 9 & Mitocôndria & S. trifasciata \\
\hline & Antihemorragic factor $\mathrm{Bj} 46 \mathrm{a}$ & 9954430 & 168.51 & 32 & 12 & 10 & Secretada & B. jararaca \\
\hline
\end{tabular}


APÊNDICE F - Proteínas da glândula acessória da serpente Bothrops jararaca que não sofreu extração de veneno identificadas através do nanoESI-LTQ/Orbitrap XL

\begin{tabular}{|c|c|c|c|c|c|c|c|c|}
\hline $\begin{array}{c}\mathrm{N}^{\circ} . \text { Banda } \\
\text { 0 d }\end{array}$ & Nome da Proteína & $\begin{array}{c}\text { Número } \\
\text { Acesso } \\
\end{array}$ & $\begin{array}{c}\text { Proteína } \\
\text {-10lgP }\end{array}$ & Cobertura \% & Peptídeos & Únicos & $\begin{array}{c}\text { Localização } \\
\text { Celular }\end{array}$ & Organismo \\
\hline & Phosphoglucose isomerase & 20067631 & 184.34 & 21 & 11 & 6 & Citoplasma & Boiga kraepelini \\
\hline & Transferrin precursor & 108792443 & 134.24 & 13 & 11 & 5 & Membrana & Python bivittatus \\
\hline & Glutaminyl cyclase & 3868931 & 115.95 & 18 & 6 & 5 & Secretada - GC & B. jararaca \\
\hline & Putative pyruvate kinase & 15558810 & 87.22 & 19 & 5 & 5 & Mitocôndria & Elaphe sp. \\
\hline & MP_III3 SVMP precursor, partial & 308212500 & 175.09 & 22 & 13 & 4 & Secretada - PIII & B. neuwiedi \\
\hline & $\overline{\mathrm{C}}$-type natriuretic peptide & 123884707 & 41.00 & 29 & 4 & 4 & Secretada - & Philodryas olfersii \\
\hline & Elongation factor 2 & 63146080 & 76.45 & 15 & 6 & 3 & Citoplasma & O. s. scutellatus \\
\hline & Snake venom metalloprotease inhibitor precursor & 159232573 & 46.57 & 18 & 4 & 3 & Secretada - pEKW & Echis ocellatus \\
\hline & Heat shock protein 90 & 89515102 & 141.81 & 12 & 12 & 2 & $\mathrm{RE}$ & Bufo gargarizans \\
\hline & Putative beta-tubulin & 324497907 & 113.95 & 26 & 3 & 2 & Citoplasma & H. judaicus \\
\hline & L-amino acid oxidase precursor & 195927838 & 157.63 & 23 & 11 & 1 & Secretada - LAAO & B. pauloensis \\
\hline & Gamma-phospholipase A2 inhibitor & 157885070 & 127.12 & 40 & 7 & 1 & Secretada - PLI & B. jararacussu \\
\hline \multirow[t]{11}{*}{7} & PDI & 63146076 & 198.63 & 33 & 16 & 16 & ER & O. scutellatus \\
\hline & Serum albumin & 56790036 & 185.24 & 18 & 13 & 13 & Secretada & T. flavoviridis \\
\hline & Vimentin & 17386168 & 165.19 & 28 & 19 & 14 & Citoplasma & Daboia russellii \\
\hline & ATP synthase beta chain & 372479772 & 165.68 & 22 & 9 & 9 & Mitocôndria & S. trifasciata \\
\hline & Antihemorragic factor $\mathrm{Bj} 46 \mathrm{a}$ & 9954430 & 168.51 & 32 & 12 & 10 & Secretada & B. jararaca \\
\hline & Phosphoglucose isomerase & 20067631 & 184.34 & 21 & 11 & 6 & Citoplasma & Boiga kraepelini \\
\hline & Putative pyruvate kinase & 15558810 & 87.22 & 19 & 5 & 5 & Mitocôndria & Elaphe sp. \\
\hline & Actin 5C & 161661023 & 307.66 & 68 & 50 & 3 & Citoplasma & L. singoriensis \\
\hline & MP_III2 SVMP precursor, partial & 308212498 & 138.46 & 30 & 16 & 2 & Secretada - PIII & B. neuwiedi \\
\hline & L-amino acid oxidase precursor & 195927838 & 157.63 & 23 & 11 & 1 & Secretada - LAAO & B. pauloensis \\
\hline & Gamma-phospholipase A2 inhibitor & 157885070 & 127.12 & 40 & 7 & 1 & Secretada - PLI & B. jararacussu \\
\hline \multirow[t]{15}{*}{8} & PDI & 63146076 & 192.13 & 42 & 26 & 25 & $\mathrm{RE}$ & O. scutellatus \\
\hline & Alpha enolase & 5305427 & 279.29 & 47 & 21 & 19 & Citoplasma & Python regius \\
\hline & Vimentin & 17386168 & 165.19 & 28 & 19 & 14 & Citoplasma & Daboia russellii \\
\hline & Antihemorragic factor $\mathrm{Bj} 46 \mathrm{a}$ & 9954430 & 168.51 & 32 & 12 & 10 & Secretada & Bothrops jararaca \\
\hline & ATP synthase alpha subunit & 118562410 & 191.70 & 36 & 7 & 5 & Mitocôndria & E. quadrivirgata \\
\hline & Bothrostatin precursor & 13194760 & 235.23 & 28 & 24 & 8 & Secretada - PII & Bothrops jararaca \\
\hline & Zinc metalloproteinase-disintegrin HF3 & 82219706 & 194.49 & 26 & 22 & 5 & Secretada - PIII & Bothrops jararaca \\
\hline & Glutaminyl cyclase & 3868931 & 115.95 & 18 & 6 & 5 & Secretada - GC & B. jararaca \\
\hline & MP_III3 SVMP precursor, partial & 308212500 & 175.09 & 22 & 13 & 4 & Secretada - PIII & B. neuwiedi \\
\hline & Actin $5 \mathrm{C}$ & 161661023 & 307.66 & 68 & 50 & 3 & Citoplasma & L. singoriensis \\
\hline & Snake venom metalloprotease inhibitor precursor & 159232573 & 43.57 & 18 & 4 & 3 & Secretada - pEKW & Echis ocellatus \\
\hline & Phospholipase A2 inhibitor & 3358089 & 41.81 & 8 & 3 & 3 & Secretada - PLI & G. brevicaudus \\
\hline & Eukaryotic translation elongation factor 1 alpha 1 & 347466178 & 174.25 & 32 & 13 & 2 & Citoplasma & Orthriophis taeniurus \\
\hline & Heat shock protein 90 & 89515102 & 141.81 & 12 & 12 & 2 & RE & Bufo gargarizans \\
\hline & Putative beta-tubulin & 324497907 & 113.95 & 26 & 3 & 2 & Citoplasma & H. judaicus \\
\hline \multirow[t]{2}{*}{9} & PDI & 63146076 & 198.63 & 33 & 16 & 16 & $\mathrm{RE}$ & O. scutellatus \\
\hline & Serum albumin & 56790036 & 185.24 & 18 & 13 & 13 & Secretada & T. flavoviridis \\
\hline
\end{tabular}


APÊNDICE F - Proteínas da glândula acessória da serpente Bothrops jararaca que não sofreu extração de veneno identificadas através do nanoESI-LTQ/Orbitrap XL

\begin{tabular}{|c|c|c|c|c|c|c|c|c|}
\hline 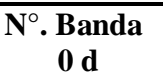 & Nome da Proteína & $\begin{array}{c}\text { Número } \\
\text { Acesso }\end{array}$ & $\begin{array}{c}\text { Proteína } \\
\text {-10lgP }\end{array}$ & Cobertura \% & Peptídeos & Únicos & $\begin{array}{c}\text { Localização } \\
\text { Celular }\end{array}$ & Organismo \\
\hline & alpha enolase & 5305427 & 279.29 & 47 & 21 & 19 & Citoplasma & Python regius \\
\hline & Vimentin & 17386168 & 165.19 & 28 & 19 & 14 & Citoplasma & Daboia russellii \\
\hline & ATP synthase beta chain & 372479772 & 165.68 & 22 & 9 & 9 & Mitocôndria & S. trifasciata \\
\hline & Zinc metalloproteinase-disintegrin HF3 & 82219706 & 194.49 & 26 & 22 & 5 & Secretada-PIII & Bothrops jararaca \\
\hline & Glyceraldehyde-3-phosphate dehydrogenase & 39652292 & 182.75 & 39 & 7 & 7 & Citoplasma & L. semifasciata \\
\hline & Glutaminyl cyclase & 3868931 & 115.95 & 18 & 6 & 5 & Secretada - GC & Bothrops jararaca \\
\hline & 60s ribosomal protein L10 & 260207865 & 88.68 & 18 & 6 & 5 & Citoplasma & Tityus discrepans \\
\hline & MP_III3 SVMP precursor, partial & 308212500 & 175.09 & 22 & 13 & 4 & Secretada - PIII & B. neuwiedi \\
\hline & C-type natriuretic peptide & 123884707 & 41.00 & 29 & 4 & 4 & Secretada & Philodryas olfersii \\
\hline & Actin $5 \mathrm{C}$ & 161661023 & 307.66 & 68 & 50 & 3 & Citoplasma & L. singoriensis \\
\hline & Snake venom serine protease BthaTL & 82173559 & 89.04 & 26 & 5 & 3 & Secretada - SVSP & B. alternatus \\
\hline & Eukaryotic translation elongation factor 1 alpha 1 & 347466178 & 174.25 & 32 & 13 & 2 & Citoplasma & Orthriophis taeniurus \\
\hline & Putative beta-tubulin & 324497907 & 113.95 & 26 & 3 & 2 & Citoplasma & H. judaicus \\
\hline \multirow[t]{14}{*}{10} & Tyrosine 3-monooxygenase/tryptophan 5- & 89515082 & 188.13 & 31 & 10 & 7 & Mitocôndria & Bufo gargarizans \\
\hline & monooxygenase activation protein, theta & - & - & - & - & - & - & - \\
\hline & polypeptide & - & - & - & - & - & - & - \\
\hline & Snake venom serine protease HS114 & 82233395 & 174.31 & 49 & 13 & 9 & Secretada - SVSP & Bothrops jararaca \\
\hline & Putative ADP/ATP translocase & 324497718 & 99.25 & 25 & 8 & 8 & Membrana & H. judaicus \\
\hline & 40S ribosomal protein $\mathrm{S} 3 \mathrm{a}$ & 82219689 & 113.76 & 30 & 8 & 7 & Citoplasma & O. Hannah \\
\hline & MP_IIb2 SVMP precursor & 308212508 & 148.47 & 20 & 10 & 6 & Secretada - PII & Bothrops neuwiedi \\
\hline & Beta-fibrinogenase & 6706013 & 65.79 & 19 & 4 & 1 & Secretada - SVSP & G. blomhoffi \\
\hline & Transport protein Sec61 beta subunit & 387018500 & 95.00 & 29 & 4 & 4 & ER & C. adamanteus \\
\hline & Actin $5 \mathrm{C}$ & 161661023 & 307.66 & 68 & 50 & 3 & Citoplasma & L. singoriensis \\
\hline & Thrombin-like enzyme asperase & 82466483 & 162.71 & 37 & 11 & 3 & Secretada - SVSP & Bothrops asper \\
\hline & Snake venom serine protease BthaTL & 82173559 & 89.04 & 26 & 5 & 3 & Secretada - SVSP & B. alternatus \\
\hline & Elongation factor 2 & 63146080 & 76.45 & 15 & 6 & 3 & Citoplasma & O. s. scutellatus \\
\hline & Disintegrin jararin & 123911605 & 142.93 & 31 & 6 & 2 & Secretada & Bothrops jararaca \\
\hline \multirow[t]{13}{*}{11} & Tyrosine 3-monooxygenase/tryptophan 5- & 89515082 & 188.13 & 31 & 10 & 7 & Mitocôndria & Bufo gargarizans \\
\hline & monooxygenase activation protein, theta & - & - & - & - & - & - & - \\
\hline & polypeptide & - & - & - & - & - & - & - \\
\hline & Snake venom serine protease HS114 & 82233395 & 174.31 & 49 & 13 & 9 & Secretada - SVSP & Bothrops jararaca \\
\hline & Metalloproteinase jararafibrase- 2 & 82219563 & 233.51 & 39 & 31 & 7 & Secretada - PII & Bothrops jararaca \\
\hline & GTP binding protein Rabla & 15281839 & 126.39 & 63 & 7 & 6 & Golgi & Gallus gallus \\
\hline & $40 S$ ribosomal protein $S 2$, partial & 71725683 & 129.14 & 35 & 9 & 5 & Citoplasma & O. scutellatus \\
\hline & Adenine nucleotide translocator & 71725703 & 103.48 & 32 & 4 & 4 & Membrana & O. scutellatus \\
\hline & Thrombin-like enzyme asperase & 82466483 & 162.71 & 37 & 11 & 3 & Secretada - SVSP & Bothrops asper \\
\hline & Elongation factor 2 & 63146080 & 76.45 & 15 & 6 & 3 & Citoplasma & O. s. scutellatus \\
\hline & Ribosomal protein L8 & 336042958 & 75.24 & 32 & 3 & 3 & Citoplasma & L. semifasciata \\
\hline & Disintegrin jararin & 123911605 & 142.93 & 31 & 6 & 2 & Secretada & Bothrops jararaca \\
\hline & Translocon-associated protein-like protein & 71725701 & 80.27 & 20 & 2 & 2 & ER & O. scutellatus \\
\hline
\end{tabular}


APÊNDICE F - Proteínas da glândula acessória da serpente Bothrops jararaca que não sofreu extração de veneno identificadas através do nanoESI-LTQ/Orbitrap XL

\begin{tabular}{|c|c|c|c|c|c|c|c|c|}
\hline $\begin{array}{c}\mathrm{N}^{\circ} . \text { Banda } \\
\text { 0 d }\end{array}$ & Nome da Proteína & $\begin{array}{c}\text { Número } \\
\text { Acesso }\end{array}$ & $\begin{array}{c}\text { Proteína } \\
-10 \lg P\end{array}$ & Cobertura \% & Peptídeos & Únicos & $\begin{array}{c}\text { Localização } \\
\text { Celular }\end{array}$ & Organismo \\
\hline \multirow{13}{*}{12} & venom gland cyclophilin & 38374146 & 157.40 & 40 & 10 & 8 & Citoplasma & Bitis gabonica \\
\hline & Gamma-phospholipase A2 inhibitor & 157885066 & 148.08 & 50 & 8 & 8 & Secretada-PLI & Bothrops jararaca \\
\hline & Metalloproteinase jararafibrase- 2 & 82219563 & 233.51 & 39 & 31 & 7 & Secretada - PII & Bothrops jararaca \\
\hline & GTP binding protein Rab1a & 15281839 & 126.39 & 63 & 7 & 6 & Golgi & Gallus gallus \\
\hline & Zinc metalloproteinase-disintegrin HF3 & 82219706 & 194.49 & 26 & 22 & 5 & Secretada - PIII & Bothrops jararaca \\
\hline & Proteasome-like protein & 71725697 & 147.64 & 41 & 7 & 5 & Citoplasma & O. scutellatus \\
\hline & 60s ribosomal protein L10 & 260207865 & 88.68 & 18 & 6 & 5 & Citoplasma & Tityus discrepans \\
\hline & 40S ribosomal protein $\mathrm{S} 18$, partial & 71725687 & 96.37 & 34 & 5 & 4 & Citoplasma & O. scutellatus \\
\hline & Actin 5C & 161661023 & 307.66 & 68 & 50 & 3 & Citoplasma & L. singoriensis \\
\hline & Alpha-phospholipase A2 inhibitor precursor & 167547107 & 119.31 & 46 & 9 & 3 & Secretada - PLI & Bothrops jararaca \\
\hline & Snake venom metalloprotease inhibitor precursor & 159232573 & 43.57 & 18 & 4 & 3 & Secretada - pEKW & Echis ocellatus \\
\hline & MP_III2 SVMP precursor, partial & 308212498 & 138.46 & 30 & 16 & 2 & Secretada - PII & B. neuwiedi \\
\hline & Translocon-associated protein-like protein & 71725701 & 80.27 & 20 & 2 & 2 & ER & O. scutellatus \\
\hline \multirow[t]{5}{*}{13} & Venom gland cyclophilin & 38374146 & 157.40 & 40 & 10 & 8 & Citoplasma & Bitis gabonica \\
\hline & Putative pyruvate kinase & 15558810 & 87.22 & 19 & 5 & 5 & Mitocôndria & Elaphe sp. \\
\hline & GPIb-BP alpha subunit & 1839441 & 177.74 & 70 & 12 & 7 & Secretada - CTL & Bothrops jararaca \\
\hline & 40S ribosomal protein $S 18$, partial & 71725687 & 96.37 & 34 & 4 & 4 & Citoplasma & O. scutellatus \\
\hline & Alpha-phospholipase A2 inhibitor precursor & 167547107 & 119.31 & 46 & 9 & 3 & Secretada & Bothrops jararaca \\
\hline \multirow[t]{7}{*}{14} & Histone $\mathrm{H} 2 \mathrm{~A}$ & 256077334 & 172.22 & 22 & 8 & 8 & Citoplasma & S. mansoni \\
\hline & Bothroinsularin subunit beta & 229621685 & 184.89 & 83 & 10 & 10 & Secretada-CTL & Bothrops insularis \\
\hline & Venom gland cyclophilin & 38374146 & 157.40 & 40 & 10 & 8 & Citoplasma & Bitis gabonica \\
\hline & Phospholipase A2 precursor & 20069137 & 182.73 & 72 & 19 & 4 & Secretada $-\mathrm{PLA}_{2}$ & Bothrops insularis \\
\hline & GPIb-BP alpha subunit & 1839441 & 177.74 & 70 & 12 & 7 & Secretada - CTL & Bothrops jararaca \\
\hline & Thrombin-like enzyme & 82466483 & 162.71 & 37 & 11 & 3 & Secretada - CTL & Bothrops asper \\
\hline & Cytochrome c & 119388034 & 86.27 & 44 & 4 & 2 & Mitocôndria & Crotalus atrox \\
\hline \multirow[t]{11}{*}{15} & HSP70 & 63146078 & 305.30 & 43 & 30 & 23 & Citoplasma & O. scutellatus \\
\hline & PDI & 63146076 & 198.63 & 33 & 16 & 16 & $\mathrm{RE}$ & O. scutellatus \\
\hline & Histone H4 & 294653213 & 194.15 & 53 & 12 & 12 & Núcleo & Pelinobius muticus \\
\hline & Bothroinsularin subunit beta & 229621685 & 184.89 & 83 & 10 & 10 & Secretada - CTL & Bothrops insularis \\
\hline & Zinc metalloproteinase-disintegrin BITM06A & 82214993 & 264.82 & 27 & 29 & 9 & Secretada - PIII & Bothrops insularis \\
\hline & Bothrocetin & 13399950 & 198.67 & 73 & 20 & 8 & Secretada - CTL & Bothrops jararaca \\
\hline & GPIb-BP beta subunit & 1839442 & 158.27 & 47 & 6 & 6 & Secretada - CTL & Bothrops jararaca \\
\hline & Phospholipase A2 precursor & 20069137 & 182.73 & 72 & 19 & 4 & Secretada - PLA $_{2}$ & Bothrops insularis \\
\hline & Transport protein Sec 61 beta subunit & 387018500 & 95.00 & 29 & 4 & 4 & ER & C. adamanteus \\
\hline & Thrombin-like enzyme asperase & 82466483 & 162.71 & 37 & 11 & 3 & Secretada - SVSP & Bothrops asper \\
\hline & Cytochrome c & 119388034 & 86.27 & 44 & 4 & 2 & Mitocôndria & Crotalus atrox \\
\hline
\end{tabular}

Nota: Dados obtidos no banco de dados Metazoa nr 19082011 e Proteopeptidome_NCBInr_29042012 do Orbitrap.

Retículo endoplasmático (ER), Lectinas tipo C (CTL), Serinoproteinases (SVSP), Proteínas secretadas ricas em cisteína (CRISP), Classes de Metaloproteinases (PI, PII, PIII), Fosfolipases A2 (PLA $)$, L-aminoácido oxidase (LAAO), Glutaminil Ciclotransferase, (GC), Fator de crescimento do endotélio vascular de serpente (svVEGF), Precursor do tri-peptídeo (pEKW). 
APÊNDICE G 
APÊNDICE G - Proteínas da glândula acessória da serpente Bothrops jararaca 4 dias após a extração de veneno identificadas através do nanoESI-LTQ/Orbitrap XL.

\begin{tabular}{|c|c|c|c|c|c|c|c|c|}
\hline $\begin{array}{l}N^{\circ} \text { Banda } \\
4 \text { d }\end{array}$ & Nome Proteína & $\begin{array}{l}\text { Número } \\
\text { Acesso }\end{array}$ & $\begin{array}{l}\text { Proteína } \\
\text {-10lgP }\end{array}$ & $\begin{array}{c}\text { Cobertura } \\
\%\end{array}$ & Peptídeos & Únicos & Localização Celular & Organismo \\
\hline \multirow[t]{3}{*}{1} & ATPase, $\mathrm{Ca}++$ transporting, cardiac muscle, slow & 269994450 & 86.37 & 7 & 2 & 2 & Mitocôndria & L. r. rubritaeniata \\
\hline & switch 2 & - & - & - & - & - & - & - \\
\hline & $\mathrm{Na} / \mathrm{K}$-ATPase & 336043940 & 181.85 & 20 & 8 & 1 & Membrana & L. semifasciata \\
\hline 2 & Putative pyruvate kinase & 15558810 & 139.22 & 36 & 10 & 9 & Mitocôndria & Elaphe sp. \\
\hline \multirow[t]{2}{*}{3} & $\begin{array}{c}\text { ATPase, } \mathrm{Ca}++ \text { transporting, cardiac muscle, slow } \\
\text { twitch } 2\end{array}$ & $\begin{array}{c}269994450 \\
-\end{array}$ & $\begin{array}{c}86.37 \\
-\end{array}$ & $\begin{array}{l}7 \\
-\end{array}$ & $\begin{array}{l}2 \\
-\end{array}$ & $\begin{array}{l}2 \\
-\end{array}$ & Mitocôndria & L. r. rubritaeniata \\
\hline & $\mathrm{Na} / \mathrm{K}-\mathrm{ATP}$ ase & 336043940 & 181.85 & 20 & 8 & 1 & Membrana & L. semifasciata \\
\hline \multirow[t]{6}{*}{4} & Antihemorragic factor $\mathrm{Bj} 46 \mathrm{a}$ & 9954430 & 240.71 & 50 & 25 & 19 & Secretada & Bothrops jararaca \\
\hline & Phosphodiesterase 1 & 338855302 & 253.27 & 25 & 23 & 14 & Citoplasma & C. adamanteus \\
\hline & Dipeptidylpeptidase $4 \mathrm{~b}$ & 40363636 & 166.23 & 15 & 11 & 5 & Membrana & Gloydius brevicaudus \\
\hline & Ubiquitin-60S ribosomal protein L40 & 302393725 & 138.58 & 48 & 6 & 5 & Citoplasma & O. hannah \\
\hline & Cullin-associated and neddylation-dissociated 1 , partial & 336245059 & 149.30 & 18 & 6 & 3 & Núcleo & Naja atra \\
\hline & Thrombin-like enzyme & 82466483 & 182.32 & 33 & 9 & 1 & Secretada - SVSP & Bothrops asper \\
\hline \multirow[t]{9}{*}{5} & Phosphodiesterase 1 & 338855302 & 253.27 & 25 & 23 & 14 & Citoplasma & C. adamanteus \\
\hline & Actinin alpha 4 & 269994460 & 213.28 & 37 & 13 & 13 & Citoplasma & L. r. rubritaeniata \\
\hline & Dipeptidylpeptidase $4 \mathrm{~b}$ & 40363636 & 166.23 & 15 & 11 & 5 & Membrana & Gloydius brevicaudus \\
\hline & HSP 90 & 67480188 & 174.32 & 18 & 8 & 3 & RE & O. s. scutellatus \\
\hline & Snake venom serine protease BITS01A & 82244284 & 149.23 & 21 & 8 & 2 & Secretada - SVSP & Bothrops insularis \\
\hline & Serum albumin & 56790036 & 258.54 & 33 & 31 & 26 & Secretada & T. flavoviridis \\
\hline & HSP70 & 63146078 & 249.29 & 47 & 33 & 21 & Citoplasma & O. s. scutellatus \\
\hline & Transferrin & 108792441 & 172.68 & 12 & 9 & 4 & Membrana & L. fuliginosus \\
\hline & Eukaryotic translation elongation factor 2 & 269994436 & 132.75 & 18 & 6 & 4 & Citoplasma & L. r. rubritaeniata \\
\hline \multirow[t]{11}{*}{6} & Serum albumin & 56790036 & 258.54 & 33 & 31 & 26 & Secretada & T. flavoviridis \\
\hline & HSP70 & 63146078 & 249.29 & 47 & 33 & 21 & Citoplasma & O. s. scutellatus \\
\hline & Antihemorragic factor $\mathrm{Bj} 46 \mathrm{a}$ & 9954430 & 240.71 & 50 & 25 & 19 & Secretada & Bothrops jararaca \\
\hline & Z. metalloproteinase-disintegrin jararhagin & 231997 & 304.02 & 41 & 47 & 14 & Secretada - PIII & Bothrops jararaca \\
\hline & Z. metalloproteinase-disintegrin jararafibrase- 2 & 13194760 & 277.65 & 41 & 37 & 7 & Secretada - PII & Bothrops jararaca \\
\hline & Transferrin & 108792441 & 172.68 & 12 & 9 & 4 & Membrana & L. fuliginosus \\
\hline & Bothropasin precursor & 4895110 & 279.89 & 41 & 40 & 3 & Secretada - PIII & Bothrops jararaca \\
\hline & HSP 90 & 67480188 & 174.32 & 18 & 8 & 3 & $\mathrm{RE}$ & O. s. scutellatus \\
\hline & L-amino acid oxidase precursor & 195927838 & 213.43 & 35 & 18 & 2 & Secretada - LAAO & B. pauloensis \\
\hline & Ecto-5' nucleotidase & 338855300 & 209.61 & 32 & 17 & 1 & Membrana & Crotalus adamanteus \\
\hline & Catroriarin & 110610039 & 131.74 & 21 & 6 & 1 & Secretada - PIII & Crotalus atrox \\
\hline \multirow[t]{5}{*}{7} & PDI & 63146076 & 250.09 & 46 & 30 & 30 & $\mathrm{RE}$ & O. s. scutellatus \\
\hline & Serum albumin & 56790036 & 258.54 & 33 & 31 & 26 & Secretada & T. flavoviridis \\
\hline & HSP70 & 63146078 & 249.29 & 47 & 33 & 21 & Citoplasma & O. s. scutellatus \\
\hline & Antihemorragic factor $\mathrm{Bj} 46 \mathrm{a}$ & 9954430 & 240.71 & 50 & 25 & 19 & Secretada & Bothrops jararaca \\
\hline & Z. metalloproteinase-disintegrin jararhagin & 231997 & 304.02 & 41 & 47 & 14 & Secretada - PIII & Bothrops jararaca \\
\hline
\end{tabular}


APÊNDICE G - Proteínas da glândula acessória da serpente Bothrops jararaca 4 dias após a extração de veneno identificadas através do nanoESI-LTQ/Orbitrap XL.

\begin{tabular}{|c|c|c|c|c|c|c|c|c|}
\hline $\begin{array}{c}N^{\circ} \text { Banda } \\
4 \mathrm{~d}\end{array}$ & Nome Proteína & $\begin{array}{l}\text { Número } \\
\text { Acesso }\end{array}$ & $\begin{array}{c}\text { Proteína } \\
\text {-10lgP }\end{array}$ & $\begin{array}{c}\text { Cobertura } \\
\%\end{array}$ & Peptídeos & Únicos & Localização Celular & Organismo \\
\hline & Putative pyruvate kinase & 15558810 & 139.22 & 36 & 10 & 9 & Mitocôndria & Elaphe sp. \\
\hline & Z. metalloproteinase-disintegrin jararafibrase-2 & 13194760 & 277.65 & 41 & 37 & 7 & Secretada - PII & Bothrops jararaca \\
\hline & Catenin beta 1 & 269994426 & 144.11 & 14 & 6 & 6 & Citoplasma & L. r. rubritaeniata \\
\hline & Phosphoglucose isomerase & 20067631 & 185.86 & 17 & 10 & 5 & Citoplasma & Boiga kraepelin \\
\hline & ATP synthase alpha chain & 372479676 & 148.46 & 10 & 7 & 5 & Mitocôndria & Sansevieria trifasciata \\
\hline & Bothropasin precursor & 4895110 & 279.89 & 41 & 40 & 3 & Secretada - PIII & Bothrops jararaca \\
\hline & L-amino acid oxidase precursor & 195927838 & 213.43 & 35 & 18 & 2 & Secretada - LAAO & B. pauloensis \\
\hline & Catroriarin & 110610039 & 131.74 & 21 & 6 & 1 & Secretada - PIII & Crotalus atrox \\
\hline & Phospholipase A2 2 & 292630844 & 56.84 & 10 & 2 & 2 & Secretada & Bothrops jararaca \\
\hline \multirow[t]{14}{*}{8} & PDI & 63146076 & 250.09 & 46 & 30 & 30 & RE & O. s. scutellatus \\
\hline & Serum albumin & 56790036 & 258.54 & 33 & 31 & 26 & Secretada & T. flavoviridis \\
\hline & Alpha enolase & 5305427 & 250.49 & 46 & 20 & 19 & Citoplasma & Python regius \\
\hline & Antihemorragic factor $\mathrm{Bj} 46 \mathrm{a}$ & 9954430 & 240.71 & 50 & 25 & 19 & Secretada & Bothrops jararaca \\
\hline & Vimentin & 17386168 & 185.07 & 29 & 17 & 15 & Citoplasma & Daboia russellii \\
\hline & Z. metalloproteinase-disintegrin jararhagin & 231997 & 304.02 & 41 & 47 & 14 & Secretada - PIII & Bothrops jararaca \\
\hline & ATP synthase beta chain & 372479772 & 167.35 & 21 & 9 & 9 & Mitocôndria & S. trifasciata \\
\hline & Putative pyruvate kinase & 15558810 & 139.22 & 36 & 10 & 9 & Mitocôndria & Elaphe sp. \\
\hline & Z. metalloproteinase-disintegrin jararafibrase-2 & 13194760 & 277.65 & 41 & 37 & 7 & Secretada - PII & Bothrops jararaca \\
\hline & Metalloproteinase precursor & 20069133 & 276.62 & 52 & 34 & 5 & Secretada - PI & Bothrops insularis \\
\hline & Phosphoglucose isomerase & 20067631 & 185.86 & 17 & 10 & 5 & Citoplasma & Boiga kraepelin \\
\hline & Eukaryotic translation elongation factor 2 & 269994436 & 132.75 & 18 & 6 & 4 & Citoplasma & L. r. rubritaeniata \\
\hline & Bothropasin precursor & 4895110 & 279.89 & 41 & 40 & 3 & Secretada - PIII & Bothrops jararaca \\
\hline & L-amino acid oxidase precursor & 195927838 & 213.43 & 35 & 18 & 2 & Secretada - LAAO & B. pauloensis \\
\hline \multirow[t]{10}{*}{9} & Alpha enolase & 5305427 & 250.49 & 46 & 20 & 19 & Citoplasma & Python regius \\
\hline & Vimentin & 17386168 & 185.07 & 29 & 17 & 15 & Citoplasma & Daboia russellii \\
\hline & Z. metalloproteinase-disintegrin jararhagin & 231997 & 304.02 & 41 & 47 & 14 & Secretada - PIII & Bothrops jararaca \\
\hline & ATP synthase beta chain & 372479772 & 167.35 & 21 & 9 & 9 & Mitocôndria & S. trifasciata \\
\hline & Z. metalloproteinase-disintegrin jararafibrase-2 & 13194760 & 277.65 & 41 & 37 & 7 & Secretada - PII & Bothrops jararaca \\
\hline & Eukaryotic translation elongation factor 2 & 269994436 & 132.75 & 18 & 6 & 4 & Citoplasma & L. r. rubritaeniata \\
\hline & Bothropasin precursor & 4895110 & 279.89 & 41 & 40 & 3 & Secretada - PIII & Bothrops jararaca \\
\hline & Glyceraldehyde-3-phosphate dehydrogenase & 39652292 & 119.70 & 22 & 4 & 3 & Citoplasma & L. semifasciata \\
\hline & Catroriarin & 110610039 & 131.74 & 21 & 6 & 1 & Secretada-PIII & Crotalus atrox \\
\hline & Actin & 294653207 & 204.18 & 52 & 18 & 1 & Citoplasma & Pelinobius muticus \\
\hline \multirow[t]{5}{*}{10} & Antihemorragic factor $\mathrm{Bj} 46 \mathrm{a}$ & 9954430 & 240.71 & 50 & 25 & 19 & Secretada & Bothrops jararaca \\
\hline & ATP synthase beta chain & 372479772 & 167.35 & 21 & 9 & 9 & Mitocôndria & S. trifasciata \\
\hline & Berythractivase & 17865171 & 198.78 & 18 & 14 & 4 & Secretada - PIII & B. erythromelas \\
\hline & Eukaryotic translation elongation factor 1 alpha 1 & 336089582 & 146.17 & 36 & 10 & 3 & Citoplasma & Nerodia fasciata \\
\hline & Glyceraldehyde-3-phosphate dehydrogenase & 39652292 & 119.70 & 22 & 4 & 3 & Citoplasma & L. semifasciata \\
\hline \multirow[t]{2}{*}{11} & Vimentin & 17386168 & 185.07 & 29 & 17 & 15 & Citoplasma & Daboia russellii \\
\hline & 40 S ribosomal protein $\mathrm{S} 2$, partial & 71725683 & 165.86 & 40 & 10 & 6 & Citoplasma & Oxyuranus scutellatus \\
\hline
\end{tabular}


APÊNDICE G - Proteínas da glândula acessória da serpente Bothrops jararaca 4 dias após a extração de veneno identificadas através do nanoESI-LTQ/Orbitrap XL.

\begin{tabular}{|c|c|c|c|c|c|c|c|c|}
\hline $\begin{array}{c}\mathrm{N}^{\circ} \text { Banda } \\
4 \mathrm{~d}\end{array}$ & Nome Proteína & $\begin{array}{c}\text { Número } \\
\text { Acesso }\end{array}$ & $\begin{array}{c}\text { Proteína } \\
\text {-10lgP }\end{array}$ & $\begin{array}{c}\text { Cobertura } \\
\%\end{array}$ & Peptídeos & Únicos & Localização Celular & Organismo \\
\hline & Metalloproteinase 3 & 338855314 & 188.44 & 24 & 14 & 4 & Secretada - PII & Crotalus adamanteus \\
\hline & Venom protein $\mathrm{Ci}-40 \mathrm{~b}$ & 315131319 & 78.67 & 10 & 4 & 4 & Citoplasma & Chelonus inanitus \\
\hline & Actin & 294653207 & 204.18 & 52 & 18 & 1 & Citoplasma & Pelinobius muticus \\
\hline & Serine protease & 32396014 & 158.86 & 46 & 11 & 2 & Secretada - SVSP & Bothrops jararacussu \\
\hline \multirow[t]{7}{*}{12} & Vimentin & 17386168 & 185.07 & 29 & 17 & 15 & Citoplasma & Daboia russellii \\
\hline & $40 S$ ribosomal protein $S 8$, partial & 71725685 & 178.90 & 45 & 7 & 7 & Citoplasma & Oxyuranus scutellatus \\
\hline & Adenine nucleotide translocator & 71725703 & 149.12 & 44 & 6 & 5 & Membrana & Oxyuranus scutellatus \\
\hline & Metalloproteinase 3 & 338855314 & 188.44 & 24 & 14 & 4 & Secretada - PII & Crotalus adamanteus \\
\hline & Venom protein $\mathrm{Ci}-40 \mathrm{~b}$ & 315131319 & 78.67 & 10 & 4 & 4 & Citoplasma & Chelonus inanitus \\
\hline & Thrombin-like enzyme & 82466483 & 182.32 & 33 & 9 & 1 & Secretada - SVSP & Bothrops asper \\
\hline & Serine protease & 32396014 & 158.86 & 46 & 11 & 2 & Secretada - SVSP & Bothrops jararacussu \\
\hline \multirow[t]{11}{*}{13} & Z. metalloproteinase-disintegrin jararafibrase-2 & 13194760 & 277.65 & 41 & 37 & 7 & Secretada - PII & Bothrops jararaca \\
\hline & Histone $\mathrm{H} 2 \mathrm{~A}$ & 256077334 & 161.54 & 22 & 6 & 6 & Núcleo & Schistosoma mansoni \\
\hline & Metalloproteinase precursor & 20069133 & 276.62 & 52 & 34 & 5 & Secretada - PI & Bothrops insularis \\
\hline & Tyrosine 3-monooxygenase/tryptophan 5- & 89515082 & 170.33 & 26 & 7 & 5 & Mitocôndria & Bufo gargarizans \\
\hline & monooxygenase activation protein, theta polypeptide & - & - & - & - & - & - & - \\
\hline & Proteasome-like protein & 71725697 & 160.92 & 33 & 5 & 5 & Citoplasma & Oxyuranus scutellatus \\
\hline & Ubiquitin-60S ribosomal protein $\mathrm{L} 40$ & 302393725 & 138.58 & 48 & 6 & 5 & Citoplasma & O. hannah \\
\hline & $60 \mathrm{~S}$ ribosomal protein L13a, partial & 71725679 & 99.98 & 20 & 5 & 5 & Citoplasma & Oxyuranus scutellatus \\
\hline & GTP binding protein Rabla & 15281839 & 125.93 & 35 & 4 & 4 & Golgi & Pantherophis guttatus \\
\hline & Eukaryotic translation elongation factor 1 alpha 1 & 336089582 & 146.17 & 36 & 10 & 3 & Citoplasma & Nerodia fasciata \\
\hline & Cysteine-rich seceretory protein $\mathrm{Da}-\mathrm{CRPb}$ & 190195339 & 130.10 & 18 & 3 & 1 & Secretada - CRISP & D. acutus \\
\hline \multirow{10}{*}{14} & Vimentin & 17386168 & 185.07 & 29 & 17 & 15 & Citoplasma & Daboia russellii \\
\hline & Z. metalloproteinase-disintegrin jararafibrase-2 & 13194760 & 277.65 & 41 & 37 & 7 & Secretada - PII & Bothrops jararaca \\
\hline & Histone $\mathrm{H} 2 \mathrm{~A}$ & 256077334 & 161.54 & 22 & 6 & 6 & Núcleo & Schistosoma mansoni \\
\hline & Metalloproteinase precursor & 20069133 & 276.62 & 52 & 34 & 5 & Secretada - PI & Bothrops insularis \\
\hline & Ubiquitin-60S ribosomal protein L40 & 302393725 & 138.58 & 48 & 6 & 5 & Citoplasma & Oxyuranus scutellatus \\
\hline & Berythractivase & 17865171 & 198.78 & 18 & 14 & 4 & Secretada - PIII & B. erythromelas \\
\hline & Metalloproteinase 3 & 338855314 & 188.44 & 24 & 14 & 4 & Secretada - PII & Crotalus adamanteus \\
\hline & $40 S$ ribosomal protein $\mathrm{S} 18$, partial & 71725687 & 94.08 & 32 & 4 & 4 & Citoplasma & Oxyuranus scutellatus \\
\hline & Bothropasin precursor & 4895110 & 279.89 & 41 & 40 & 3 & Secretada - PIII & Bothrops jararaca \\
\hline & Alpha-phospholipase A2 inhibitor precursor & 167547107 & 156.30 & 47 & 9 & 3 & Secretada - PLI & Bothrops jararaca \\
\hline \multirow{8}{*}{15} & Vimentin & 17386168 & 185.07 & 29 & 17 & 15 & Citoplasma & Daboia russellii \\
\hline & Z. metalloproteinase-disintegrin jararhagin & 231997 & 304.02 & 41 & 47 & 14 & Secretada - PIII & Bothrops jararaca \\
\hline & GPIb-BP alpha subunit & 1839441 & 198.56 & 55 & 13 & 8 & Secretada - PIII & Bothrops jararaca \\
\hline & Histone H2A & 256077334 & 161.54 & 22 & 6 & 6 & Núcleo & Schistosoma mansoni \\
\hline & Venom gland cyclophilin & 38374146 & 160.50 & 43 & 8 & 6 & Citoplasma & Bitis gabonica \\
\hline & $40 \mathrm{~S}$ ribosomal protein $\mathrm{S} 18$, partial & 71725687 & 94.08 & 32 & 4 & 4 & Citoplasma & Oxyuranus scutellatus \\
\hline & Histone & 109159040 & 170.56 & 65 & 8 & 3 & Núcleo & Bembrops heterurus \\
\hline & Actin & 294653207 & 204.18 & 52 & 18 & 1 & Citoplasma & Pelinobius muticus \\
\hline
\end{tabular}


APÊNDICE G - Proteínas da glândula acessória da serpente Bothrops jararaca 4 dias após a extração de veneno identificadas através do nanoESI-LTQ/Orbitrap XL.

\begin{tabular}{|c|c|c|c|c|c|c|c|c|}
\hline $\begin{array}{c}N^{\circ} \text { Banda } \\
4 \text { d }\end{array}$ & Nome Proteína & $\begin{array}{c}\text { Número } \\
\text { Acesso }\end{array}$ & $\begin{array}{c}\text { Proteína } \\
-10 \lg P\end{array}$ & $\begin{array}{c}\text { Cobertura } \\
\%\end{array}$ & Peptídeos & Únicos & Localização Celular & Organismo \\
\hline & Translocon-associated protein-like protein & 71725701 & 122.78 & 20 & 2 & 2 & $\mathrm{RE}$ & Oxyuranus scutellatus \\
\hline
\end{tabular}

Nota: Dados obtidos no banco de dados Metazoa nr 19082011 e Proteopeptidome_NCBInr_29042012 do Orbitrap.

Retículo endoplasmático (ER), Lectinas tipo C (CTL), Serinoproteinases (SVSP), Proteínas secretadas ricas em cisteína (CRISP), Classes de Metaloproteinases (PI, PII, PIII),

Fosfolipases A2 ( $\mathrm{PLA}_{2}$ ), L-aminoácido oxidase (LAAO), Glutaminil Ciclotransferase, (GC), Fator de crescimento do endotélio vascular de serpente (svVEGF), Precursor do tri-peptídeo $(\mathrm{pEKW})$. 
APÊNDICE H 
APÊNDICE H: Proteínas da glândula acessória da serpente Bothrops jararaca 7 dias após a extração de veneno através do nanoESILTQ/Orbitrap XL.

\begin{tabular}{|c|c|c|c|c|c|c|c|c|}
\hline $\begin{array}{c}\mathrm{N}^{\circ} . \text { Banda } \\
7 \text { d }\end{array}$ & Nome Proteína & $\begin{array}{c}\text { Número } \\
\text { Acesso }\end{array}$ & $\begin{array}{c}\text { Proteína } \\
-101 g P \\
\end{array}$ & $\begin{array}{c}\text { Cobertura } \\
\%\end{array}$ & Pepetídeos & Únicos & Componente Celular & Organismo \\
\hline \multirow[t]{7}{*}{1} & Antihemorragic factor BJ46a & 48428681 & 204.19 & 34 & 13 & 10 & Secretada & Bothrops jararaca \\
\hline & Histone $\mathrm{H} 4$ & 294653213 & 178.02 & 52 & 10 & 10 & Núcleo & Pelinobius muticus \\
\hline & GPIb-BP subunit beta & 82116883 & 165.02 & 43 & 5 & 5 & Secretada - CTL & Bothrops jararaca \\
\hline & Bothroinsularin subunit beta & 229621685 & 146.30 & 48 & 5 & 5 & Secretada - CTL & Bothrops insularis \\
\hline & Cytochrome c & 119388034 & 124.97 & 31 & 3 & 2 & Mitocôndria & Crotalus atrox \\
\hline & svVEGF & 48428663 & 72.50 & 18 & 2 & 2 & Secretada - svVEGF & Bothrops jararaca \\
\hline & $\mathrm{Na} / \mathrm{K}$-ATPase & 336043940 & 157.16 & 19 & 7 & 1 & Membrana & L. semifasciata \\
\hline \multirow[t]{2}{*}{2} & Aminopeptidase A & 148367284 & 148.36 & 3 & 2 & 1 & Citoplasma & G. brevicaudus \\
\hline & $\mathrm{Na} / \mathrm{K}$-ATPase & 336043940 & 157.16 & 19 & 7 & & Membrana & L. semifasciata \\
\hline \multirow[t]{2}{*}{3} & Vimentin & 17386168 & 201.53 & 26 & 16 & 14 & Citoplasma & Daboia russelli \\
\hline & $\mathrm{Na} / \mathrm{K}$-ATPase & 336043940 & 157.16 & 19 & 7 & 1 & Membrana & L. semifasciata \\
\hline \multirow[t]{2}{*}{4} & Phosphodiesterase 1 & 338855302 & 244.06 & 19 & 17 & 12 & Citoplasma & Crotalus adamanteus \\
\hline & Aminopeptidase A & 148367284 & 148.36 & 3 & 2 & 1 & Citoplasma & G. brevicaudus \\
\hline \multirow[t]{10}{*}{5} & Actinin alpha 4 & 269994460 & 222.76 & 31 & 13 & 13 & Citoplasma & L. r. rubritaeniata \\
\hline & Phosphodiesterase 1 & 338855302 & 244.06 & 19 & 17 & 12 & Citoplasma & Crotalus adamanteus \\
\hline & Antihemorragic factor cHLP-B & 82126266 & 146.10 & 18 & 8 & 4 & Secretada & G. brevicaudus \\
\hline & Golgi-associated protein & 67480125 & 127.41 & 29 & 4 & 4 & Golgi & O. s. scutellatus \\
\hline & Heat shock protein 90 & 89515102 & 162.79 & 11 & 7 & 2 & $\mathrm{RE}$ & Bufo gargarizans \\
\hline & Elongation factor 2 & 63146080 & 122.52 & 11 & 4 & 2 & Citoplasma & O. s. scutellatus \\
\hline & Na/K-ATPase & 336043940 & 157.16 & 19 & 7 & 1 & Membrana & L. semifasciata \\
\hline & Heat shock protein 8 -like & 269994458 & 196.01 & 41 & 12 & 5 & Citoplasma & L. r. rubritaeniata \\
\hline & Zinc metalloproteinase-disintegrin HF3 & 82219706 & 160.45 & 11 & 8 & 2 & Secretada - PIII & Bothrops jararaca \\
\hline & Transferrin precursor & 108792443 & 122.47 & 5 & 5 & 2 & Membrana & Python bivittatus \\
\hline \multirow[t]{10}{*}{6} & PDI & 63146076 & 257.93 & 43 & 29 & 29 & ER & O. s. scutellatus \\
\hline & HSP70 & 63146078 & 250.53 & 30 & 23 & 14 & Citoplasma & O. s. scutellatus \\
\hline & Serum albumin & 56790036 & 214.23 & 25 & 16 & 12 & Secretada & T. flavoviridis \\
\hline & Antihemorragic factor BJ46a & 48428681 & 204.19 & 34 & 13 & 10 & Secretada & Bothrops jararaca \\
\hline & Putative pyruvate kinase & 15558810 & 135.67 & 26 & 7 & 7 & Mitocôndria & Elaphe sp \\
\hline & ATP synthase beta chain & 372479772 & 123.72 & 14 & 6 & 6 & Mitocôndria & S. trifasciata \\
\hline & Heat shock protein 8-like & 269994458 & 196.01 & 41 & 12 & 5 & Citoplasma & L. r. rubritaeniata \\
\hline & Phosphoglucose isomerase & 20067631 & 145.26 & 14 & 9 & 5 & Citoplasma & Boiga kraepelini \\
\hline & ATP synthase alpha chain & 372479676 & 128.91 & 8 & 5 & 3 & Mitocôndria & S. trifasciata \\
\hline & L-amino acid oxidase precursor & 195927838 & 176.98 & 20 & 11 & 2 & Secretada - LAAO & B. pauloensis \\
\hline \multirow[t]{5}{*}{7} & PDI & 63146076 & 257.93 & 43 & 29 & 29 & ER & O. s. scutellatus \\
\hline & HSP70 & 63146078 & 250.53 & 30 & 23 & 14 & Citoplasma & O. s. scutellatus \\
\hline & Serum albumin & 56790036 & 214.23 & 25 & 16 & 12 & Secretada & T. flavoviridis \\
\hline & Eukaryotic translation elongation factor 1 & 336089582 & 141.64 & 27 & 10 & 3 & Citoplasma & Nerodia fasciataB. \\
\hline & alpha 1 & - & - & - & - & - & - & pauloensis \\
\hline
\end{tabular}


APÊNDICE H - Proteínas da glândula acessória da serpente Bothrops jararaca 7 dias após a extração de veneno identificadas através do nanoESI-LTQ/Orbitrap XL.

\begin{tabular}{|c|c|c|c|c|c|c|c|c|}
\hline $\begin{array}{c}\mathrm{N}^{\circ} . \text { Banda } \\
7 \text { d }\end{array}$ & Nome Proteína & $\begin{array}{l}\text { Número } \\
\text { Acesso }\end{array}$ & $\begin{array}{c}\text { Proteína } \\
\text {-10lgP }\end{array}$ & $\begin{array}{c}\text { Cobertura } \\
\%\end{array}$ & Pepetídeos & Únicos & Componente Celular & Organismo \\
\hline & L-amino acid oxidase precursor & 195927838 & 176.98 & 20 & 11 & 2 & Secretada - LAAO & Bothrops jararaca \\
\hline & Zinc metalloproteinase-disintegrin HF3 & 82219706 & 160.45 & 11 & 8 & 2 & Secretada - PIII & Crotalus adamanteus \\
\hline & metalloproteinase 3 & 338855314 & 130.66 & 13 & 6 & 2 & Secretada - PIII & Crotalus atrox \\
\hline & Catroriarin & 110610039 & 110.77 & 21 & 5 & 1 & Secretada - PIII & \\
\hline \multirow[t]{10}{*}{8} & PDI & 63146076 & 257.93 & 43 & 29 & 29 & ER & O. s. scutellatus \\
\hline & Alpha enolase & 5305427 & 228.41 & 37 & 12 & 11 & Citoplasma & Python regius \\
\hline & Antihemorragic factor BJ46a & 48428681 & 204.19 & 34 & 13 & 10 & Secretada & Bothrops jararaca \\
\hline & Putative pyruvate kinase & 15558810 & 135.67 & 26 & 7 & 7 & Mitocôndria & Elaphe sp \\
\hline & Phosphoglucose isomerase & 20067631 & 145.26 & 14 & 9 & 5 & Citoplasma & Boiga kraepelini \\
\hline & ATP synthase alpha chain & 372479676 & 128.91 & 8 & 5 & 3 & Mitocôndria & Sansevieria trifasciata \\
\hline & Glyceraldehyde-3-phosphate & 39652292 & 118.14 & 18 & 3 & 3 & Citoplasma & Laticauda semifasciata \\
\hline & dehydrogenase & - & - & - & - & - & - & - \\
\hline & L-amino acid oxidase precursor & 195927838 & 176.98 & 20 & 11 & 2 & Secretada - LAAO & B. pauloensis \\
\hline & Z. metalloproteinase-disintegrin Jararhagin & 62468 & 230.95 & 18 & 16 & 1 & Secretada - PIII & Bothrops jararaca \\
\hline \multirow[t]{11}{*}{9} & Vimentin & 17386168 & 201.53 & 26 & 16 & 14 & Citoplasma & Daboia Russelli \\
\hline & Alpha enolase & 5305427 & 228.41 & 37 & 12 & 11 & Citoplasma & Python regius \\
\hline & Antihemorragic factor BJ46a & 48428681 & 204.19 & 34 & 13 & 10 & Secretada & Bothrops jararaca \\
\hline & ATP synthase beta chain & 372479772 & 123.72 & 14 & 6 & 6 & Mitocôndria & Sansevieria trifasciata \\
\hline & Insularinase and insularin precursor & 52426579 & 201.41 & 23 & 14 & 3 & Secretada - PIII & Bothrops insularis \\
\hline & Metalloproteinase 3 & 338855314 & 130.66 & 13 & 6 & 2 & Secretada - PIII & Crotalus adamanteus \\
\hline & Elongation factor 2 & 63146080 & 122.52 & 11 & 4 & 2 & Citoplasma & O. s. scutellatus \\
\hline & Elongation Factor 1 & 67480091 & 79.80 & 15 & 2 & 2 & Citoplasma & O. s. scutellatus \\
\hline & Actin 5C & 161661023 & 273.74 & 36 & 19 & 1 & Citoplasma & Lycosa singoriensis \\
\hline & Z. metalloproteinase-disintegrin Jararhagin & 62468 & 230.95 & 18 & 16 & 1 & Secretada - PIII & Bothrops jararaca \\
\hline & Catroriarin & 110610039 & 110.77 & 21 & 5 & 1 & Secretada - PIII & Crotalus atrox \\
\hline \multirow[t]{5}{*}{10} & HSP70 & 63146078 & 250.53 & 30 & 23 & 14 & Citoplasma & O. s. scutellatus \\
\hline & Vimentin & 17386168 & 201.53 & 26 & 16 & 14 & Citoplasma & Daboia russelli \\
\hline & glyceraldehyde-3-phosphate dehydrogenase & 39652292 & 118.14 & 18 & 3 & 3 & Citoplasma & Laticauda semifasciata \\
\hline & Elongation factor 2 & 63146080 & 122.52 & 11 & 4 & 2 & Citoplasma & O. s. scutellatus \\
\hline & Actin 5C & 161661023 & 273.74 & 36 & 19 & 1 & Citoplasma & Lycosa singoriensis \\
\hline \multirow[t]{6}{*}{11} & Metalloproteinase jararafibrase-2 & 82219563 & 181.80 & 29 & 20 & 4 & Secretada - PII & Bothrops jararaca \\
\hline & Snake venom serine protease HS114 & 82233395 & 119.08 & 24 & 5 & 4 & Secretada - SVSP & Bothrops jararaca \\
\hline & Insularinase and insularin precursor & 52426579 & 201.41 & 23 & 14 & 3 & Secretada - PII & Bothrops insularis \\
\hline & Metalloproteinase 3 & 338855314 & 130.66 & 13 & 6 & 2 & Secretada - PIII & Crotalus adamanteus \\
\hline & Elongation factor 2 & 63146080 & 122.52 & 11 & 4 & 2 & Citoplasma & O. s. scutellatus \\
\hline & Adenine nucleotide translocator & 71725703 & 51.12 & 13 & 2 & 2 & Membrana & Oxyuranus scutellatus \\
\hline \multirow[t]{4}{*}{12} & Vimentin & 17386168 & 201.53 & 26 & 16 & 14 & Citoplasma & Daboia russelli \\
\hline & Histone $\mathrm{H} 2 \mathrm{~A}$ & 256077334 & 175.44 & 22 & 8 & 8 & Núcleo & Schistosoma mansoni \\
\hline & Venom gland cyclophilin & 38374146 & 151.37 & 35 & 7 & 5 & Citoplasma & Bitis gabonica \\
\hline & GTP binding protein Rab1a & 15281839 & 122.84 & 43 & 5 & 5 & Golgi & Gallus gallus \\
\hline
\end{tabular}


APÊNDICE H - Proteínas da glândula acessória da serpente Bothrops jararaca 7 dias após a extração de veneno identificadas através do nanoESI-LTQ/Orbitrap XL.

\begin{tabular}{|c|c|c|c|c|c|c|c|c|}
\hline $\begin{array}{c}\mathrm{N}^{\circ} . \text { Banda } \\
7 \mathrm{~d}\end{array}$ & Nome Proteína & $\begin{array}{l}\text { Número } \\
\text { Acesso }\end{array}$ & $\begin{array}{l}\text { Proteína } \\
\text {-10lgP }\end{array}$ & $\begin{array}{c}\text { Cobertura } \\
\%\end{array}$ & Pepetídeos & Únicos & Componente Celular & Organismo \\
\hline & Metalloproteinase jararafibrase-2 & 82219563 & 181.80 & 29 & 20 & 4 & Secretada - PII & Bothrops jararaca \\
\hline & $\begin{array}{l}\text { Tyrosine 3-monooxygenase/tryptophan 5- } \\
\text { monooxygenase activation protein }\end{array}$ & 89515082 & $\begin{array}{c}114.53 \\
-\end{array}$ & 23 & $\begin{array}{l}6 \\
-\end{array}$ & $\begin{array}{l}4 \\
-\end{array}$ & Mitocôndria & Bufo gargarizans \\
\hline & Insularinase and insularin precursor & 52426579 & 201.41 & 23 & 14 & 3 & Secretada - PIII & Bothrops insularis \\
\hline & Alpha-phospholipase A2 inhibitor precursor & 167547107 & 153.18 & 51 & 9 & 3 & Secretada- PLI & Bothrops jararaca \\
\hline & Proteasome-like protein & 71725697 & 144.70 & 24 & 3 & 3 & Citoplasma & Oxyuranus scutellatus \\
\hline & Histone & 109159040 & 142.62 & 55 & 7 & 3 & Núcleo & Bembrops heterurus \\
\hline & Eukaryotic translation elongation factor 1 & 336089582 & 141.64 & 27 & 10 & 3 & Citoplasma & Nerodia fasciata \\
\hline & alpha 1 & - & - & - & - & - & - & - \\
\hline & Calbindin D28K & 58003506 & 108.10 & 17 & 3 & 3 & Citoplasma & Pantherophis guttatus \\
\hline & Ribosomal protein L14 & 18000283 & 68.87 & 25 & 3 & 3 & Citoplasma & Lapemis hardwickii \\
\hline & Zinc metalloproteinase-disintegrin HF3 & 82219706 & 160.45 & 11 & 8 & 2 & Secretada -PIII & Bothrops jararaca \\
\hline & Z. metalloproteinase-disintegrin Jararhagin & 62468 & 230.95 & 18 & 16 & 1 & Secretada - PIII & Bothrops jararaca \\
\hline & Catroriarin & 110610039 & 110.77 & 21 & 5 & 5 & Secretada - PIII & Crotalus atrox \\
\hline \multirow[t]{11}{*}{13} & Histone H4 & 294653213 & 178.02 & 52 & 10 & 10 & Núcleo & Pelinobius muticus \\
\hline & C-type lectin & 41353970 & 171.74 & 47 & 9 & 6 & Secretada - CTL & Bothrops insularis \\
\hline & GTP binding protein Rabla & 15281839 & 122.8411 & 43 & 5 & 5 & Golgi & Gallus gallus \\
\hline & $\begin{array}{l}\text { Tyrosine 3-monooxygenase/tryptophan 5- } \\
\text { monooxygenase activation protein }\end{array}$ & 89515082 & 14.53 & 23 & 6 & 4 & Mitocôndria & Bufo gargarizans \\
\hline & Ribosomal protein S15 isoform & 18000277 & 113.54 & 31 & 5 & 4 & Citoplasma & Lapemis hardwickii \\
\hline & 40S ribosomal protein $\mathrm{S} 18$, partial & 71725687 & 86.41 & 32 & 4 & 4 & Citoplasma & Oxyuranus scutellatus \\
\hline & Insularinase and insularin precursor & 52426579 & 201.41 & 23 & 14 & 3 & Secretada - PIII & Bothrops insularis \\
\hline & Alpha-phospholipase A2 inhibitor precursor & 167547107 & 153.18 & 51 & 9 & 3 & Secretada - PLI & Bothrops jararaca \\
\hline & Histone & 109159040 & 142.62 & 55 & 7 & 3 & Núcleo & Bembrops heterurus \\
\hline & Cytochrome c & 119388034 & 124.97 & 31 & 3 & 2 & Mitocôndria & Crotalus atrox \\
\hline & Actin 5C & 161661023 & 273.74 & 36 & 19 & 1 & Citoplasma & Lycosa singoriensis \\
\hline \multirow[t]{8}{*}{14} & GPIb-BP alpha subunit & 1839441 & 182.37 & 50 & 11 & 8 & Secretada - CTL & Bothrops jararaca \\
\hline & Histone $\mathrm{H} 2 \mathrm{~A}$ & 256077334 & 175.44 & 22 & 8 & 8 & Núcleo & Schistosoma mansoni \\
\hline & Venom gland cyclophilin & 38374146 & 151.37 & 35 & 7 & 5 & Citoplasma & Bitis gabonica \\
\hline & 40 S ribosomal protein $\mathrm{S} 18$, partial & 71725687 & 86.41 & 32 & 4 & 4 & Citoplasma & Oxyuranus scutellatus \\
\hline & Alpha-phospholipase A2 inhibitor precursor & 167547107 & 153.18 & 51 & 9 & 3 & Secretada - PLI & Bothrops jararaca \\
\hline & Histone & 109159040 & 142.62 & 55 & 7 & 3 & Núcleo & Bothrops jararaca \\
\hline & Translocon-associated protein-like protein & 71725701 & 101.26 & 20 & 2 & 2 & RE & Oxyuranus scutellatus \\
\hline & Chain C, Crystal Structure Of Botrocetin & 13399950 & 128.90 & 39 & 6 & 1 & Secretada - CTL & Bothrops jararaca \\
\hline \multirow[t]{6}{*}{15} & Histone H4 & 294653213 & 178.02 & 52 & 10 & 10 & Núcleo & Pelinobius muticus \\
\hline & GPIb-BP alpha subunit & 1839441 & 182.37 & 50 & 11 & 8 & Secretada - CTL & Bothrops jararaca \\
\hline & Histone $\mathrm{H} 2 \mathrm{~A}$ & 256077334 & 175.44 & 22 & 8 & 8 & Núcleo & Schistosoma mansoni \\
\hline & C-type lectin & 41353970 & 171.7411 & 47 & 9 & 6 & Secretada - CTL & Bothrops insularis \\
\hline & Ribosomal protein L30 & 10442706 & 37.66 & 37 & 6 & 6 & Citoplasma & Ophiophagus Hannah \\
\hline & Ribosomal protein $\mathrm{S} 15$ isoform & 18000277 & 113.54 & 31 & 5 & 4 & Citoplasma & Lapemis hardwickii \\
\hline
\end{tabular}


APÊNDICE H - Proteínas da glândula acessória da serpente Bothrops jararaca 7 dias após a extração de veneno identificadas através do nanoESI-LTQ/Orbitrap XL.

\begin{tabular}{|c|c|c|c|c|c|c|c|c|}
\hline $\begin{array}{c}\mathrm{N}^{\circ} \text {. Banda } \\
7 \mathrm{~d} \\
\end{array}$ & Nome Proteína & $\begin{array}{c}\text { Número } \\
\text { Acesso }\end{array}$ & $\begin{array}{c}\text { Proteína } \\
\text {-10lgP }\end{array}$ & $\begin{array}{c}\text { Cobertura } \\
\%\end{array}$ & Pepetídeos & Únicos & Componente Celular & Organismo \\
\hline & Cytochrome c & 119388034 & 124.97 & 31 & 3 & 2 & Mitocôndria & Crotalus atrox \\
\hline & Ttransport protein Sec61 beta subunit & 18000273 & 102.77 & 26 & 2 & 2 & RE & Lapemis hardwickii \\
\hline & Thioredoxin protein & 12958636 & 84.94 & 17 & 2 & 2 & Citoplasma & Ophiophagus Hannah \\
\hline & svVEGF & 48428663 & 72.50 & 18 & 2 & 2 & Secretada - svVEGF & Bothrops jararaca \\
\hline & Chain C, Crystal Structure Of Botrocetin & 13399950 & 128.90 & 39 & 6 & 1 & Secretada - CTL & Bothrops jararaca \\
\hline
\end{tabular}

Nota: Dados obtidos no banco de dados Metazoa nr 19082011 e Proteopeptidome_NCBInr_29042012 do Orbitrap.

Retículo endoplasmático (ER), Lectinas tipo C (CTL), Serinoproteinases (SVSP), Proteínas secretadas ricas em cisteína (CRISP), Classes de Metaloproteinases (PI, PII, PIII), Fosfolipases A2 ( $\mathrm{PLA}_{2}$ ), L-aminoácido oxidase (LAAO), Glutaminil Ciclotransferase, (GC), Fator de crescimento do endotélio vascular de serpente (svVEGF), Precursor do tri-peptídeo (pEKW). 